UNIVERSIDADE DE SÃO PAULO

ESCOLA DE COMUNICAÇÕES E ARTES

PROGRAMA DE PÓS-GRADUAÇÃO EM

CIÊNCIA DA COMUNICAÇÃO

LAURA MATTOS SOARES QUINTAS

\title{
"Roque Santeiro" e a ditadura militar brasileira em três atos: a política por trás das telas
}

São Paulo

2016 


\section{"Roque Santeiro" e a ditadura militar brasileira em três atos: a política por trás das telas}

Dissertação apresentada à Escola de Comunicações e Artes da Universidade de São Paulo para obtenção do título de mestre em Ciência da Comunicação

Área de Concentração: Estudo dos Meios e da Produção Mediática

Orientador: Prof. Dr. Eugênio Bucci 
Autorizo a reprodução e divulgação total ou parcial deste trabalho, por qualquer meio convencional ou eletrônico, para fins de estudo e pesquisa, desde que citada a fonte.

Catalogação na Publicação

Serviço de Biblioteca e Documentação

Escola de Comunicações e Artes da Universidade de São Paulo

Dados fornecidos pela autora

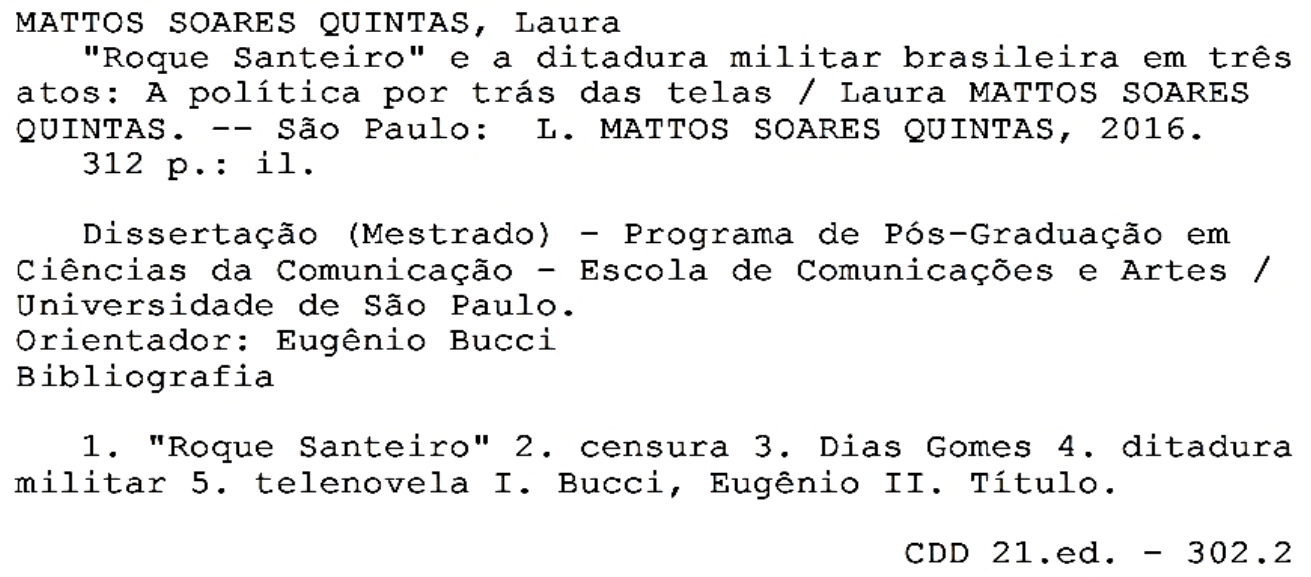


Nome: MATTOS SOARES QUINTAS, Laura

Título: "Roque Santeiro" e a ditadura militar brasileira em três atos: a política por trás das telas

Dissertação apresentada à Escola de Comunicações e Artes da Universidade de São Paulo para obtenção do título de mestre em Ciência da Comunicação

Aprovada em:

Banca Examinadora

Prof. Dr. __ Instituição:

Julgamento: Assinatura:

Prof. Dr. Instituição:

Julgamento: Assinatura:

Prof. Dr. Instituição:

Julgamento: Assinatura: 
Para Rose, Luciano, Rogério, Fernando e Henrique 


\section{Agradecimentos}

À Escola de Comunicações e Artes da USP, pelo duplo acolhimento, na graduação e neste mestrado, e à "Folha de S.Paulo", onde sempre encontrei incentivo para buscar aperfeiçoamento profissional e crescimento intelectual.

Ao Prof. Dr. Eugênio Bucci, que, ao longo dos anos em que fui repórter da "Ilustrada", ajudou-me a observar e a retratar a televisão para além do que se vê nas telas, e agora, como meu orientador, guiou-me, com sua serenidade inabalável, em um mergulho mais profundo nesse universo que envolve política e comunicação.

Ao Prof. Dr. Marcelo Ridenti, o primeiro a sugerir que esta pesquisa, que iniciei com o propósito de produzir uma reportagem, poderia se transformar em um mestrado, pela generosidade em debater comigo aspectos de sua obra vitais para este trabalho. À Prof. Dra. Maria Cristina Castilho Costa, por me dar instrumentos para abordar a censura em sua complexidade. Ao Prof. Dr. Marcos Napolitano, pela clareza e pelo equilíbrio com que analisa, na sua obra e em sala de aula, a ditadura militar brasileira.

A Bernadeth Lyzio, viúva de Dias Gomes, pela autorização que me concedeu para obter a documentação do escritor no SNI e por colocar à minha disposição o acervo particular do dramaturgo. A Alfredo Dias Gomes, filho do autor e de Janete Clair, que, na casa em que a família morou, dividiu comigo lembranças que mesclam o afeto e a preocupação em ser preciso em relação aos fatos e justo com a memória de seus pais.

A todos os que me deram entrevistas e se esforçaram para recapitular acontecimentos de até cinco décadas atrás, em especial a Marcílio Moraes, Lauro César Muniz e Boni, que, com paciência e disposição, vasculharam suas recordações ou foram atrás de documentos a fim de dar conta de minhas tantas indagações.

A Sérgio Rizzo, pelas dicas na preparação para o processo seletivo do mestrado.

A Rogério Gentile, pela parceria na vida e leitura crítica desta dissertação. A minha irmã Diana, pela presença e suporte no meu dia a dia. A meus pais, por tudo, e a meus filhos, pelo amor que me move.

Muitas outras pessoas me ajudaram com dicas valorosas, troca de ideias ou na obtenção de dados, dentre elas Alberto Dines, Ana Paula Sousa, Bruno Molinero, Edmundo Leite, Elio Gaspari, Fernando Barros e Silva, Mário Magalhães, Mauro Alencar, Nahuel Ribke, Rubens Valente, Rutonio Jorge Fernandes de Sant'Anna, Ruy Castro, Sergio Miceli e Sílvia Fiuza. 


\section{RESUMO}

MATTOS SOARES QUINTAS, L. "Roque Santeiro" e a ditadura militar brasileira em três atos: a política por trás das telas. $312 \mathrm{f}$. Dissertação (mestrado) - Escola de Comunicações e Artes, Universidade de São Paulo, São Paulo, 2016.

"Roque Santeiro", de Dias Gomes, é mais que o maior fenômeno de audiência da teledramaturgia brasileira. É uma obra em três atos, capaz de trazer à tona o início, o meio e o fim da ditadura militar brasileira, cada fase com suas diferentes formas de censura. No primeiro, temos a peça teatral "O Berço do Herói”, em 1965, que daria origem à trama televisiva. A história de um cabo, falso herói da Força Expedicionária Brasileira, é censurada no dia da estreia. Dez anos depois, em segundo ato, uma versão da peça feita para a TV Globo, já com o nome de "Roque Santeiro" e 36 capítulos gravados, ganha o traumático título de a primeira telenovela integralmente censurada no País, um dia antes do lançamento, em 1975. Por fim, em 1985, duas décadas após a proibição da peça, a novela, em um nova versão, gravada com outros atores, vai ao ar, consagrada pela crítica e pelo público. Nesse terceiro ato, é embalada como símbolo da abertura política brasileira, mas, nos bastidores, enfrenta seguidos cortes da Censura, que não se desmonta no período da redemocratização, quando o País já tinha um presidente civil, mas não uma nova Constituição, que só seria promulgada em 1988. A base desta pesquisa são fontes primárias, que vêm à público pela primeira vez: cerca de duas mil páginas de documentos dos arquivos da Censura relacionados à obra e de todos os registros sobre Dias Gomes no SNI (Serviço Nacional de Informações), além de um diário pessoal em que ele narra o processo de criação de "O Pagador de Promessas", base de sua dramaturgia, e de correspondências entre o autor, a Globo e o governo. A esse corpus se somam reportagens da época e depoimentos de profissionais ligados a Dias Gomes especialmente concedidos para este trabalho, que pretende mostrar a força simbólica desse produto midiático ("Roque Santeiro") como revelador de um período histórico do País, a partir da relação triangular entre um célebre comunista, o governo militar e a maior emissora de televisão do País.

Palavras-chave: "Roque Santeiro", censura, telenovela, ditadura militar, Dias Gomes, TV Globo 


\begin{abstract}
MATTOS SOARES QUINTAS, L. "Roque Santeiro" and the Brazilian military

dictatorship in three acts: the politics behind the screens. 312 p. Dissertation (MA) School of Communication and Arts, University of São Paulo, São Paulo, 2016.
\end{abstract}

\begin{abstract}
"Roque Santeiro", by Dias Gomes, is more than just the largest audience phenomenon of Brazilian soap operas. It is a work in three acts, able to bring out the beginning, middle and end of the Brazilian military dictatorship, each stage with its differe nt forms of censorship. In the first act, we have the "O Berço do Herói" play, in 1965, which would lead to the television plot. It is about the story of an army corporal, false hero of the Brazilian Expeditionary Force, which is censored on the day of the premiere. Ten years later, in the second act, a version of the play made for Globo TV, already using the name "Roque Santeiro" and with 36 recorded chapters, wins the traumatic title of the first soap opera fully censored in the country, a day before its premiere, in 1975. Finally, in 1985, two decades after the ban of the play, the soap opera, in a new version, recorded with other actors, goes on, consecrated by the critics and the audience. In this third act, it is seem as a symbol of the Brazilian political opening, but behind the scenes, it still faces followed Censorship cuts, which is not broken in the period of democratization, when the country already had a civil president, but not a new constitution, which only was enacted in 1988. The basis of this research are primary sources, which come to public for the first time: about two thousand pages of documents of the Censorship files related to the work and all the records about Dias Gomes on SNI (National Information Service), as well as a personal diary in which he writes about the process of creation of "O Pagador de Promessas", base of his dramaturgy, and some correspondences between the author, Globo and the government. This material was enhanced by reports of the time and professional testimonials connected to Dias Gomes specially granted for this work, which aims to show the symbolic power of this media product ("Roque Santeiro") disclosing a country's historical period, based on the triangular relationship between a famous communist, the military government and the largest television station in the country.
\end{abstract}

Keywords: "Roque Santeiro", censorship, soap opera, military dictatorship, Dias Gomes, Globo TV 


\section{SUMÁRIO}

\section{INTRODUÇÃO}

\subsection{PARTE 1 - O OBJETO}

Como "Roque Santeiro" pode trazer à tona três momentos chaves

da história do País e da TV brasileira ............................................................. 10

\subsection{PARTE 2 - UMA PESQUISA DE COMUNICAÇÃO}

Referências teóricas e caminhos metodológicos

2. PRIMEIRO ATO - 1965

Morto no nascimento - "O Berço do Herói”" .................................................... 36

2.1. Capítulo 1 - Encontro com Carlos Lacerda ............................................... 37

2.2. Capítulo 2 - O diário inédito ............................................................... 42

2.3. Capítulo 3-O falso mito, mais que pornográfico .................................... 64

3. SEGUNDO ATO - 1975

Hoje não tem novela - "Roque Santeiro" 1 ................................................. 90

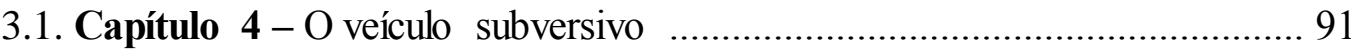

3.2. Capítulo 5 - A gente se vê na Globo ................................................... 104

3.3. Capítulo 6-O meu, o seu, os nossos comunistas .................................. 113

3.4. Capítulo 7 - Emprego para Camões .......................................................... 136

3.5. Capítulo 8 - Boa noite, censura ............................................................ 143

3.6. Capítulo 9-Despertar lento e gradual .................................................... 165

4. TERCEIRO ATO - 1985

A novela que foi sem nunca ter sido - "Roque Santeiro" 2 ....................... 186

4.1. Capítulo 10 - Asas para voar, sem se divorciar .................................... 187

4.2. Capítulo 11 - Espelho quebrado da burguesia ....................................... 200

4.3. Capítulo 12 - Democratura ..................................................................... 214 
4.4. Capítulo 13 - Diabo morto, inferno vivo ................................................ 227

4.5. Capítulo 14 - A Nova República e o "sic” do SNI .................................. 236

4.6. Capítulo 15 - Tô certo ou tô errado? ...................................................... 249

5. CONSIDERAÇÕES FINAIS ..................................................................... 274

6. APÊNDICES

6.1. Relação de entrevistados ............................................................... 282

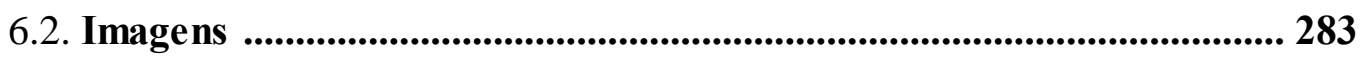

7. REFERÊNCIAS BIBLIOGRÁFICAS ....................................................... 301 


\section{INTRODUÇÃO}

\subsection{PARTE 1 - O OBJETO \\ Como Roque Santeiro pode trazer à tona três momentos chaves da história do País e da TV brasileira}

Exibida na TV Globo em 1985, "Roque Santeiro", de Dias Gomes, teve uma primeira versão censurada pelo governo militar em 1975. Com 36 capítulos já gravados $^{1}$, foi impedida de ir ao ar na véspera do lançamento, tornando-se a primeira novela inteiramente proibida no Brasil ${ }^{2}$. Sua história começara dez anos antes, com a peça "O Berço do Herói”, na qual foi baseada, e que foi vetada no dia da estreia, por censores do governador Carlos Lacerda, aliado dos militares.

A obra, sobre um povoado que vive em torno do mito de um falso herói ${ }^{4}$, pode ser vista, portanto, como uma saga em três atos de um autor contra a censura, em três momentos políticos e cultura is do País: 1965, data da censura da peça "O Berço do Herói”; 1975, quando se deu a proibição de "Roque Santeiro" na TV; e 1985, ano da exibição da nova versão na Globo. Como a ditadura militar brasileira ${ }^{5}$ se instalou em

\footnotetext{
${ }^{1}$ Dicionário da TV Globo - vol. 1: Programas de Dramaturgia \& Entretenimento. Rio de Janeiro: Jorge Zahar Editor, 2003, p. 142

2 Além de "Roque Santeiro", só mais uma novela seria proibida na íntegra: "Despedida de Casado", de Walter George Durst, em dezembro de 1976; fato assim não voltou a se repetir na história do país.

${ }^{3}$ A íntegra da peça foi publicada em 2005 em livro da coleção Dias Gomes, da editora Bertrand Brasil.

${ }^{4} \mathrm{Na}$ peça, Cabo Jorge se torna herói ao morrer na Itália lutando pela FEB (Força Exped icionária Brasileira) contra os nazistas. Sua cidade passa a viver em torno do mito, inclusive explorando-o financeiramente. Até que ele reaparece. Não havia morrido. Desertara. E as forças conservadoras, que lucram com o mito do falso herói, farão de tudo para escondê-lo. Na versão para a TV, a fim de evitar problemas com a Censura, o personagem deixa de ser um militar, torna-se um produtor de imagens de santos que morreu defendendo a cidade As a Branca, síntese do coronelismo nordestino brasileiro, contra um bandido que ameaçava o local, em especial a Igreja.

${ }^{5}$ Há ampla discussão na historiografia sobre o uso dos termos "ditadura civil-militar" e "golpe civilmilitar" em substituição a "ditadura militar" e "golpe militar". Basicamente, a intenção é ressaltara participação de setores da sociedade civil no golpe e na manutenção do regime. Em banca de qualificação para esta pesquisa, Maria Cristina Castilho Costa lembrou esse debate, sublinhando que a censura é sempre amparada pela sociedade civil, mesmo quando regida pelo Estado. Nesta dis sertação, a opção será usar apenas "militar", com base no artigo "Ditadura militar ou civil-militar?", de Marcelo Ridenti (um dos primeiros a utilizar "civil-militar"), que, após ponderações sobre vantagens e desvantagens de cada um, conclui que "não importa tanto se um autor usa o termo militar ou civil-militar para caracterizar o golpe, o regime ou a ditadura, mas sim como ele analis a seu objeto, que envolve uma intrincada relação entre militares e civis que precisa ser desvendada"; disponívelem http://onlinelibrary.wiley.com/doi/10.1111/blar.12519/abstract;jsessionid=D8FC47B944E84222B9AB3E FC582A5908.f04t04?userIs Authenticated $=$ false \&denied Acces $s$ Cus tomisedMes sage $=($ aces so em $22 / 6 / 2016)$
} 
1964 e só saiu de cena em 1985, "Roque Santeiro" costuma ser lembrada ao mesmo tempo como símbolo da censura e da abertura política no País.

Esse é o objeto desta pesquisa, que é desdobramento de um ano sabático que pude tirar na "Folha de S.Paulo", após 12 anos na cobertura de temas ligados à televisão no caderno "Ilustrada" -não só da programação, como de aspectos políticos e econômicos desse veículo de comunicação. No período de afastamento da Redação para aprimoramento profissional, de janeiro a novembro de 2011, investi no estudo da teledramaturgia brasileira, concentrando-me em Dias Gomes e na novela "Roque Santeiro", caso histórico de sucesso de audiência da televisão brasileira -nas três primeiras semanas, já era sintonizada por $72 \%$ dos domicílios da Grande Rio e por $61 \%$ das casas da Grande São Paulo, o melhor resultado da emissora até então ${ }^{6}$; no $34^{\circ}$ capítulo, um resultado impressionante: 97,6\% dos aparelhos ligados na Grande Rio estavam na novela ${ }^{7}$; durante a maior parte de seu período de exibição, de 24 de junho de 1985 a 21 de fevereiro de 1986, a média nacional variou entre 80\%, e alguns capítulos chegaram aos virtuais $100 \%$ dos televisores ligados, tornando-se a maior audiência de todos os tempos ${ }^{8}$.

Ao longo da pesquisa, obtive toda a documentação relacionada à obra na Divisão de Censura de Diversões Públicas, além dos registros sobre Dias Gomes e outros profissionais da TV Globo no Serviço Nacional de Informação, o SNI. Ao todo, são cerca de duas mil páginas.

Em encontros com a viúva de Dias Gomes, Bernadeth Lyzio ${ }^{9}$, tive acesso ao arquivo do escritor, que inclui trocas de correspondência entre ele e a direção da Globo, entre outras, como saborosas conversas com os amigos também comunistas Ferreira Gullar e Jorge Amado (esse último seu compadre, padrinho de sua filha Mayra). Fui autorizada por Lyzio a fazer cópia de um diário em que Dias relata, entre outras histórias, o processo de criação e de montagem da peça “O Pagador de Promessas”, seu grande clássico teatral, cuja adaptação para o cinema obteve o principal prêmio -a Palma de Ouro- do Festival de Cannes de 1962. Em junho 2001, como repórter da "Ilustrada", da "Folha", noticiei que uma disputa judicial pela herança do escritor -entre Lyzio e os filhos de Dias Gomes com Janete Clair- ameaçavam inviabilizar os planos

\footnotetext{
${ }^{6}$ O retorno do mito, Veja, ed. $880,17 / 7 / 1985$, p. 108-109 [matéria não assinada]

${ }^{7}$ Mania nacional, Is to É, 14/8/1985, p. 32-35 [matéria não assinada]

${ }^{8}$ COURI, Norma. Playboy entrevista Dias Gomes, "Playboy", 12/1985, p. 49

${ }^{9}$ Em sua residência, no Rio de Janeiro, nos dias 3/3/2011 e 4/5/2011.
} 
da viúva de publicar o diário ${ }^{10}$. A batalha jurídica se arrastou, e o documento seguia inédito até a conclusão desta dissertação. Aqui, pela primeira vez, parte do seu conteúdo é revelada.

No diário, o período crucial da formação do autor foi por ele registrado ora com caneta azul, ora preta, em um pequeno caderno, com $22 \mathrm{~cm}$ de comprimento por $15 \mathrm{~cm}$ de largura, envolto por uma capa dura costurada às páginas, como era comum naquele tempo. No momento em que tive acesso ao caderno, ele estava em uma das caixas que a viúva guarda com outros documentos do escritor, em sua casa, em um condomínio na Barra da Tijuca, no Rio, para a qual se mudou após a morte do autor (por acidente de carro, em São Paulo, no dia 18 de maio de 1999). As páginas estão naturalmente amareladas, com as beiradas corroídas pelo tempo e algumas rasgadas, dividindo o texto. O autor não tem a letra das mais legíveis, escreve como um médico nos receituários. Quando erra, rabisca a palavra por cima, com muitos traços, de forma a realmente torná-la ilegível, como a evitar que aquilo pudesse ser lido -há passagens com até quatro linhas seguidas riscadas assim. São 78 páginas manuscritas, que foram por mim numeradas para organizar as citações que farei nesta dissertação.

Inédito, o diário vai de 1959 a 1962, e obviamente não trata do centro de nosso objeto, "Roque Santeiro" (uma vez que a peça "O Berço do Herói” só seria escrita em 1963), mas mostra os dilemas que o autor, antes de sua consagração, vivia para colocar no papel (e nos palcos) seu ideário de esquerda, além de deixar clara a sua quase obsessão por retratar nas obras - e com isso idealmente transformar- o que entendia ser a realidade brasileira.

Sua militância política seria despertada muito antes, em 1942, quando tinha apenas 19 anos e escreveu a sua primeira peça a ser encenada profissionalmente, "Pé de Cabra”. O texto estrearia com montagem de Procópio Ferreira no dia 31 de julho daquele ano. Nesse dia, Dias resolveu passar em frente ao Teatro Serrador, no Rio, para ver seu nome no cartaz, mas o que ele leu foi "Estreia adiada" e, assim, o autor era oficialmente apresentado à censura institucionalizada do Estado.

A peça havia sido vetada pelo DIP (Departamento de Imprensa e Propaganda), criado pela ditadura de Getúlio Vargas. Em sua autobiografia, publicada em 1998, Dias conta que o texto havia sido considerado "marxista" e "jura por Deus", com seu

\footnotetext{
${ }^{10}$ MATTOS, Laura. Disputa ameaça publicação de diário de Dias Gomes. Folha de S.Paulo, 6/6/2001, p. E4
} 
característico estilo irônico, que nunca havia lido Marx até então. Aí resolveu ler. A entrada no Partido Comunista Brasileiro se daria no ano seguinte ${ }^{11}$.

No diário, acompanhamos suas angústias para conceber um teatro respeitado como arte e politicamente relevante, além de sua inquietude ao se ver entre a condição de militante de esquerda e intelectual midiático.

"A ânsia de me realizar e a frustração que carregava comigo haviam se transformado em verdadeiras obsessões”, escreveria em 10 de agosto de 1959, na abertura do caderno. Em 18 de julho de 1961, demonstra-se incomodado com o sucesso. "Sinto-me traidor de mim mesmo. Três violações de personalidade me ocorreram esta semana: recebi um prêmio da Academia [Brasileira de Letras] ${ }^{12}$, fui homenageado com um almoço na presença de Luiz Carlos Prestes e Oduvaldo Vianna ${ }^{13}$, entre outros, e tive que comparecer (por dever e gratidão) à posse de Jorge Amado [na $\mathrm{ABL}$ ]. Começo a ser dominado por esse sentimento de culpa inexplicável, como se estivesse me acomodando, me aburguesando, me academizando vergonhosamente. Chega, chega, chega."

Na última anotação no diário, em 31 de maio de 1962, é provocador consigo mesmo, ao comentar a Palma de Ouro recebida pelo filme "O Pagador de Promessas". "Passei a ser herói nacional. Parece-me que em tudo isso há um grande equívoco."

Além do diário, cartas e diversas entrevistas mostram que Dias, para usar os termos consagrados por Norbert Elias, passou sua vida nesse eterno questionar entre a condição de outsider e estabelecido. Era um intelectual, autor de teatro, militante ou um vendido escritor de novela de TV? Trocou o teatro pela Globo apenas por estabilidade financeira ou, tendo sido vítima da censura nos palcos, queria aproveitar a grande audiência da televisão para dar voz às suas convicções políticas?

Era um questionamento interno, que ressoava pressões externas de diferentes vertentes. Seguindo ainda no raciocínio de Elias, o autor se mostrava muitas vezes ressentido em meio a essa "sociodinâmica da estigmatização"14.

\footnotetext{
${ }^{11}$ GOMES, Dias. Apenas um subversivo. Rio de Janeiro: Bertrand Brasil, 1998, p. 67

${ }^{12}$ No texto do diário está escrito apenas "Academia", as palavras "Brasileira de Letras" foram colocadas em colchetes para facilitar a leitura.

${ }^{13}$ É provável que ele esteja se referindo ao pai, que tinha exatamente o mesmo nome do filho, conhecido como Vianinha. Como pai e filho têm trajetórias semelhantes, na carreira artística e militância política, também seria possívelque fosse o filho presente ao evento da ABL, então decidimos manter o registro original do diário sem inferir que seja um ou outro.

${ }^{14}$ ELIAS, Norbert \& Scotson. John L. Os estabelecidos e os outsiders. Rio de Janeiro: Jorge Zahar, 2000, p. 23
} 
"Ele é um subversivo", disse Carlos Lacerda sobre Dias Gomes ao justificar a censura de "O Berço do Herói”, em 1965, para os atores da peça, que aguardaram o governador do Estado da Guanabara na porta de seu apartamento para tentar reverter a situação. O adjetivo "subversivo" aparece também em fichas confidenciais do SNI, entre outros termos, como "comunista infiltrado", "comunista notório e confesso", "incentivador da luta de classes", "membro da esquerda festiva".

Por outro lado, tinha de lidar com a vigilância da esquerda, a chamada "patrulha ideológica". Em 24 de março de 1960, escreveu no diário sobre a dificuldade de aceitação, no Partido, do personagem Rafael, da peça “A Invasão", que acabara de criar. "Este personagem não está sendo bem entendido por alguns companheiros do Partido. Seu sectarismo (pretendo demonstrar que embora haja no Partido comunistas sectários, estes comunistas são pessoas bem-intencionadas e eficientes, apesar de tudo, apesar de estarem erradas em seus métodos). Seu sectarismo, acham esses companheiros, o torna antipático e leva a plateia a concluir que todos os comunistas são assim. Não estou de acordo. E pretendo manter o personagem." De todos os lados, vivia cercado por estigmas, usados na sociedade, como aponta Goffman"15, para "categorizar as pessoas".

O desconforto sobre sua própria condição e a busca por uma produção ficcional política, que começara na adolescência, seguiriam por toda a sua carreira e teriam em "Roque Santeiro" sua maior exposição midiática.

Para esta pesquisa, afora a citada gama de documentos da ditadura militar garimpados nos arquivos oficiais, foi realizado um levantamento que reuniu as citações a Dias Gomes, a "O Berço do Herói” e a "Roque Santeiro" em quatro dos principais jornais do País nas épocas das obras: "Jornal do Brasil", "O Globo", "O Estado de S. Paulo" e "Folha de S.Paulo". Esses bancos de dados, além de reportagens dos próprios periódicos, trazem ainda textos de outras publicações, como "Tribuna da Imprensa", "Última Hora", "Veja" e "Isto É", entre outras.

Por fim, foi realizada uma série de entrevistas com profissionais ligados ao autor e à novela -entre outros nomes, José Bonifácio de Oliveira, o Boni (que tinha o mais alto cargo da Globo à época das novelas), Ferreira Gullar (amigo de Dias, colega de profissão e companheiro de partido), Glória Perez (amiga do casal Dias Gomes e Janete Clair e então aprendiz da escritora na televisão) e Marcílio Moraes (autor do grupo que

${ }^{15}$ GOFFMAN, E. Estigma. $2^{\text {a }}$ ed. Rio de Janeiro: Jorge Zahar, 1978, p. 21-22 
trabalhou na versão de "Roque Santeiro" de 1985), além de outros pioneiros da televisão, familiares e outros amigos do escritor.

A reunião desse material deixou claro que ainda havia muito a ser revelado e discutido a respeito de "Roque Santeiro" e sobre a complexa trama de relações e acontecimentos envolvidos nesse consagrado produto televisivo. São diversas abordagens possíveis que não estão na autobiografia de Dias Gomes, "Apenas um Subversivo"16, em outros livros sobre a história da televisão e da teledramaturgia, nas reportagens da época ou em produções acadêmicas por mim encontrados.

No mencionado período sabático de 2011, o plano era produzir um livroreportagem sobre "Roque Santeiro", algo como uma "biografia" desse fenômeno da televisão. Mas, diante da quantidade de material reunido, de sua complexidade e das infinitas possibilidades que o tema oferecia, concluí que a pesquisa não deveria ser trabalhada apenas jornalisticamente, e que na academia encontraria suporte teórico para uma maior reflexão. Assim, todo o corpus desta pesquisa, reunido na ocasião de minha licença, pôde ser organizado e analisado a partir de uma metodologia com a qual tive contato no mestrado.

O objetivo da presente dissertação é problematizar os contextos político e cultural que envolvem "Roque Santeiro". Não só do ponto de vista do que foi apresentado à audiência brasileira, ou seja, da novela que foi ao ar, mas principalmente do que não veio a público e que abrange, entre outros aspectos, a triangulação entre Dias Gomes (notório membro do Partido Comunista), a TV Globo (que se firmava como emissora líder do País justamente por meio de sua teledramaturgia e com apoio do governo), e a ditadura militar (munida da censura, entre outros aparatos da repressão).

"Roque Santeiro" foi, nas duas décadas de repressão política do País, um produto emblemático da indústria cultural -conceito criado por Adorno e Horkheimer nos anos $1940^{17}$-, que, como apontou Lopes, "passa a ser um lugar privilegiado de mediação do Estado em suas relações com a sociedade civil"18.

Nossa hipótese é que essa obra em três atos (a peça, a novela censurada e a exibida) é representativa da ditadura brasileira em seu início, meio e fim. O primeiro ato se dá em meio à fase que vai do golpe, em 1964, à assinatura do AI-5, em 1968. É o

\footnotetext{
16 GOMES, Dias. Apenas um subversivo. Rio de Janeiro: Bertrand Brasil, 1998

17 MATTELART, Armand e MATTELART, Michèle. História das teorias da Comunicação. São Paulo: Loyola, 1998, p. 77

18 LOPES, Maria Immacolata V. Pesquisa em Comunicação. São Paulo: Edições Loyola, 2005, p. 27
} 
período que o jornalista Elio Gaspari chama de "ditadura envergonhada"19, também conhecida pelo polêmico nome de "ditabranda", quando, conforme aponta o historiador Marcos Napolitano, o regime suprimia os movimentos sociais e políticos, mas permitia que a esquerda derrotada parecesse triunfar na cultura ${ }^{20}$. A peça "O Berço do Herói” foi proibida nesse ínterim, em 1965, quando a censura costumava ser realizada pelos Estados e ainda não se encontrava totalmente centralizada no governo federal. Foi vetada, em 22 de julho, no Rio, onde estrearia, por ordem do governador Carlos Lacerda, à época ainda apoiador do regime recém-instalado.

O segundo ato veio a público em 27 de agosto de 1975, quando Cid Moreira, âncora do "Jornal Nacional", leu um editorial durante dois minutos denunciando aos telespectadores que a novela "Roque Santeiro", que estrearia naquela noite após o telejornal, havia sido censurada pelos militares. O veto havia sido assinado na véspera da estreia. O episódio, marcante para a história da televisão e do País, acontece na passagem do segundo para o terceiro período da ditadura.

A segunda fase abarca os anos entre 1968, pós AI-5, e 1974, quando há o extermínio da guerrilha do Araguaia e termina o mandato de Emílio Garrastazu Médici, em 15 de março. É o tempo conhecido como "anos de chumbo" - por Gaspari batizada de "ditadura escancarada" $1_{\text {- }}$, com o maior número de casos de torturas, mortes e com o acirramento da censura.

Já o terceiro momento da ditadura é o chamado de "abertura", de 1974 até a eleição de Tancredo Neves, que pôs fim ao governo militar, em 1985 -que, para Gaspari compreende a "ditadura derrotada e encurralada"22 (de 1974 até 1977, quando houve a crise da demissão do ministro do Exército, o general Sylvio Frota, um dos principais nomes da "linha dura", que se articulava para pleitear a presidência da República), e a "ditadura acabada"23 (o governo Figueiredo).

Em 1985, "Roque Santeiro" foi escolhida pela Globo para ir ao ar com a intenção de exaltar o fim da ditadura. A novela censurada, feita a partir da peça proibida, finalmente viria a público nesse terceiro ato da obra. Reportagens da época celebravam

\footnotetext{
${ }^{19}$ GASPARI, Elio. A ditadura envergonhada. São Paulo: Companhia das Letras, 2002

${ }^{20}$ NAPOLITANO, Marcos. O mito da "ditabranda". In: Idem. 1964 - História do regime militar brasileiro. São Paulo: Contexto, 2014, p. 69

${ }^{21}$ GASPARI, Elio. A ditadura escancarada. São Paulo: Companhia das Letras, 2002

22 Idem. A ditadura derrotada. São Paulo: Companhia das Letras, 2003; Idem. A ditadura encurralada. São Paulo: Companhia das Letras, 2004

23 GASPARI, Elio. A ditadura acabada. Rio de Janeiro: Intrínseca, 2016
} 
o acontecimento como representativo dos novos tempos. Para ilustrar essa ideia disseminada na ocasião, vale mencionar trecho do livro "Telenovela Brasileira Memória", o primeiro a catalogar telenovelas brasileiras. "E o Brasil se reuniu mais uma vez em frente à televisão para assistir à inteligente sátira nacional de Dias Gomes, censurada em 1975 e [que] só com os ares da Nova República pôde estrear e se exibir por inteiro (grifo nosso). ${ }^{\circ 4}$ A ironia é que mais de mil páginas da Divisão de Censura e Divertimento Público (DCDP), coletadas para esta pesquisa no Arquivo Nacional do Ministério da Justiça, apontam que foram inúmeros os cortes sofridos na versão exibida pela Globo, o que mantinha tensa a relação entre censores e produtores da emissora. Torna-se, assim, perfeitamente possível demonstrar que a visão cravada naquele instante, e que parece incrustada na memória do País até a atualidade, é equivocada: "Roque Santeiro", versão 1985, quis marcar a era da redemocratização, mas comprova a manutenção da censura. O celebrado fim da ditadura simbolizado por "Roque Santeiro" deveria vir entre aspas. A telenovela da "volta" da democracia seria tão censurada que pode, na verdade, revelar o quanto ficou preservado da ditadura pelo menos até a Constituição de 1988, quando a censura institucional do Estado teve fim oficialmente e se instalou a classificação indicativa.

Se essa obra de Dias Gomes pode ser localizada nas passagens entre cada uma das fases em que a ditadura é dividida politicamente por Gaspari, ela é ainda mais emblemática quando a divisão temporal se dá por um prisma mais específico : a repressão sobre a cultura. Para isso, nosso fundamento é a vasta pesquisa de Napolitano sobre o regime militar e a produção cultural do período.

“O Berço do Herói”, em 1965, está na primeira fase, de 1964 a 1968, quando o objetivo principal do governo "era dissolver as conexões entre a 'cultura de esquerda' e as classes populares". Nesse período, elucida Napolitano, a pressão se dava principalmente através de IPMs (Inquéritos Policiais-Militares) envolvendo artistas -e aqui registramos a presença de volumosa documentação sobre Dias Gomes no SNI para a nossa pesquisa. 'Neste primeiro momento, a área mais visada pela censura era o

\footnotetext{
${ }^{24}$ FERNANDES, Ismael. Telenovela brasileira. Memória. São Paulo: Brasiliense, $3^{\mathrm{a}}$ edição, 1994, p. 309. O livro foi escrito em 1982, com reedição em 1994; o autor (1945-1997), formado em jornalismo e história, ficou conhecido como colunista de televisão de jornais.
} 
teatro, menos pelo alcance social e mais pela sua capacidade de mobilização dos setores intelectuais de oposição", escreve Napolitano ${ }^{25}$.

A primeira versão de "Roque Santeiro", de 1975, está na segunda fase de repressão cultural do regime, de 1969 a 1978, que "tinha como objetivo central reprimir o movimento da cultura como mobilizadora do radicalismo da classe média". Napolitano explica que foi o período em que os militares se armaram com a Lei de Censura e outros decretos que legalizaram e organizaram a repressão à cultura.

O terceiro momento vai de 1979 a 1985, ano da exibição de "Roque Santeiro". Nesse último ano, o regime havia acabado oficialmente. Após a derrota da campanha popular pelas eleições diretas, em 1984, Tancredo Neves, do PMDB, candidato de oposição aos militares, é eleito de forma indireta, por um colégio eleitoral, em 15 de janeiro de 1985, e tomaria posse no dia 15 de março. Na véspera, é internado e seu vice, José Sarney, empossado em seu lugar -Tancredo morreria em 21 de abril, um trauma para a nação embevecida com a promessa de um novo tempo.

"Roque Santeiro" estreou em 22 de junho de 1985. A obra proibida era finalmente liberada no ano em que a redemocratização tomava a pauta do País. A TV encenava a festa brasileira no seu horário nobre. Só que convidara Dias Gomes, e ele presenteou a audiência com a ironia da ironia. Foi a novela do falso mito que estourou de audiência quando, apesar da transição para uma presidência civil, a estrutura de poder da ditadura seguiu mantida, com seus legados de repressão, entre eles a censura.

Àquela altura, conforme escreve Napolitano, o objetivo central dos censores "era controlar o processo de desagregação da ordem política e moral vigentes, estabelecendo limites de conteúdo e linguagem" -no início de 1986, pressionado pela Igreja Católica, o presidente José Sarney daria diretamente a ordem para censurar o filme "Je vous salue, Marie", de Gordard.

Esses três momentos -tanto as divisões políticas propostas por Gaspari como as relativas à repressão à cultura categorizadas por Napolitano- devem ser vistos como “tipos ideais", a embasarem esta análise; obviamente, na prática, os fatos se misturam e há nuances que cruzam marcações temporais, o que também não pretendemos ignorar. Mas, a partir da documentação de cada um dos atos da saga de "Roque Santeiro" -a

${ }^{25}$ As referências a Marcos Napolitano aqui são do livro $\mathbf{1 9 6 4}$ - História do regime militar brasileiro. São Paulo: Contexto, 2014, p. 100. Nesse trecho sobre o teatro, o autor trabalha com tese de doutorado de Miliandre Garcia de Souza, "Ou vocês mudam, ou acabam": teatro e censura na ditadura militar (1964-1985), Rio de Janeiro: UFRJ, 2008. 
peça, a versão de 1975 e a de 1985- podemos avaliar aspectos distintos da censura nos diferentes períodos, a especificidade de vetos ao teatro e à $\mathrm{TV}$, e como se dava a relação entre artistas de esquerda, a indústria cultural e o governo.

Nesse sentido, o estudo da obra é rico na elucidação de como a censura, usada como ferramenta da repressão, foi se construindo na prática e no papel, porque, como aponta Kushnir, os períodos de exceção no Brasil têm a preocupação de "legislar e, assim, dar aos atos de arbítrio aparência e conteúdo de legalidade".

É interessante perceber que, apesar de existir um "processo de continuidade [do ponto de vista legal], com nuanças de transformação", como também afirma Kushnir, grande parte da censura do regime militar se respaldou em aparato legis lativo elaborado logo após o fim dos 15 anos da ditadura Vargas -que fizera uma inovação em termos censórios no País, ao criar o Departamento de Imprensa e Propaganda: além da repressão ao que não interessava ao governo, o DIP funcionava como alavanca de publicidade ao regime; além disso, diferentemente de órgãos anteriores, normalmente vinculados a departamentos de segurança estaduais, ligava-se diretamente ao Ministério da Justiça, ou seja, ao primeiro escalão da presidência da República e era dirigido pelo jornalista Lourival Fontes, fiel a Vargas e simpático ao fascismo italiano ${ }^{26}$.

Em 1965, a proibição de “O Berço do Herói” foi justificada, segundo afirmou a Dias Gomes o chefe da Censura Estadual, Asdrúbal Sodré Júnior 27 , "pelo artigo 41 do Regulamento". Ele se referia a artigo do decreto 20.493, que regulamenta o Serviço de Censura de Diversões Públicas do Departamento Federal de Segurança Pública, e proibia, entre outros vetos, roteiros que induzissem "ao desprestígio das Forças Armadas". Foi assinado em 24 de janeiro de 1946 por José Linhares.

Presidente do Supremo Tribunal Federal desde 1937, o então mandatário do País havia sido convocado por uma junta militar para assumir o cargo a partir de 29 de outubro de 1945 (dia em que Vargas foi deposto por seus ministros militares) e ali permaneceu até o marechal Dutra, vencedor de eleições diretas, ser empossado, em 31 de janeiro de 1946. Em meio a uma ditadura e um golpe militar, e com a assinatura de um presidente-tampão a apenas uma semana de deixar o cargo, o decreto 20.493

\footnotetext{
${ }^{26}$ SCHWARCZ, Lilia M. e STARLING, Heloisa M. Brasil: uma biografia. São Paulo: Companhia das Letras, 2015, p. 376

${ }^{27}$ GOMES, Dias. "Apenas um subversivo”. Rio de Janeiro: Bertrand Brasil, 1998; o diálogo está nas páginas 215 e 216.
} 
justificou a maioria dos pareceres dos censores por mais de quatro décadas, até a Constituição de $1988^{28}$.

Já a censura da primeira versão de "Roque Santeiro", em agosto de 1975, a mais marcante da televisão brasileira, se dá após a posse de Geisel, em 1974, que falava em abertura "lenta, gradativa e segura" 29 . A novela entraria no ar em 27 de agosto, quando Cid Moreira leu, no "Jornal Nacional", o editorial da Globo denunciando o veto. O episódio, de enorme repercussão, aconteceu apenas dois meses antes do assassinato do jornalista Wladimir Herzog por agentes do Doi-Codi (Destacamento de Operações de Informações - Centro de Operações de Defesa Interna), no quartel-general do $2^{\circ}$ Exército, em São Paulo, no dia 25 de outubro. Portanto, percebe-se que o aparato censório e a violência dos porões seguiam intactos, apesar do discurso de distensão.

Para além do que era dito na troca de documentos entre a Globo e a censura sobre "Roque Santeiro" - a fachada oficial da proibição, empacotada como uma decisão legal pelo regime, com amparo em seu arsenal regulatório- estava um telefonema clandestinamente grampeado pelo Serviço Nacional de Informações (SNI) entre Dias Gomes e o historiador Nelson Werneck Sodré, em que o dramaturgo satirizava os militares por não terem percebido que a novela era uma versão da peça censurada " $O$ Berço do Herói”". O episódio mostra face ainda mais sombria da repressão militar à produção cultural.

Em 1985, as cerca de 500 páginas referentes à "Roque Santeiro" na Divisão de Censura e Divertimento Público (DCDP) deixam claro: visto que proibições por razões políticas, pautadas pela Doutrina da Segurança Nacional, não seriam mais admitidas explicitamente pela sociedade, a estrutura de repressão, que seguia montada, foi obrigada a se concentrar na "moral e nos bons costumes". O problema, pelo menos oficialmente, não seria mais a possibilidade de o coronelato de Sinhozinho Malta e suas manobras para manter o poder em Asa Branca serem uma alusão aos desmandos governamentais do Brasil. Os olhos censórios se fixariam nas cenas do coronel na cama com a Viúva Porcina. Claro que a questão moral sempre encobre propósitos políticos,

\footnotetext{
${ }^{28}$ Para o cálculo dos pareceres, KUSHNIR, Beatriz. Cães de Guarda - Jornalistas e censores do AI-5 à Constituição de 1988. São Paulo: Boitempo, 2004, p. 101.

${ }^{29}$ Apesar de a expressão mais disseminada ser "lenta, gradual e segura", a frase original do discurso utiliza a palavra "gradativa", conforme pode ser constatado emáudio no especial sobre os 50 anos do golpe da Folha de S.Paulo, cuja fonte é o Arquivo Nacional: BALTAZHAR, Ricardo et al. Tudo sobre a ditadura militar, 23/3/2014, disponível em arte.folha.uol.com.br/especiais/2014/03/23/o-golpe-e-aditadura-militar (acesso em 22/6/2016).
} 
tanto por parte dos censores, como dos autores - que, durante os anos de ditadura usaram a telenovela com deliberada intenção de criticar a moral burguesa, que era, ao lado da questão da "segurança nacional", pilar regime autoritário.

No "novo" Brasil pós ditadura, mais do que nunca, os lençóis do adultério seriam utilizados pela censura para acobertar seu objetivo em última instância, sempre político $^{30}$.

\footnotetext{
${ }^{30}$ Para o viés sempre político da censura, ver COSTA, Maria Cristina Castilho. Opinião pública, comunicação, liberdade de expressão e censura. In: Idem (Org.). A censura em debate. São Paulo: ECA/USP, 2014, p. 27-34; e KUSHNIR, Beatriz. Cães de Guarda - Jornalis tas e censores do AI-5 à Constituição de 1988. São Paulo: Boitempo, 2004, p. 106. Também relevantes para mostrar que a censura moral está atrelada ao projeto político são as pesquis as sobre os vetos a canções bregas na ditatura em ARAÚJO, Paulo Cesar de. Eu não sou cachorro não. Rio de Janeiro: Record, 2002; ROLEMBERG, Denise. O Bem-Amado e a censura - uma relação rigorosa ou flexível? e CARDENUTO, Reinaldo. A sobrevida da dramaturgia comunista na televisão dos anos 1970 - o percurso de um realismo crítico em negociação; ambos In: NAPOLITANO, Marcos; CZAJKA, Rodrigo; MOTTA, Rodrigo Patto Sá. Comunistas Brasileiros - Cultura política e produção cultural. Belo Horizonte: Editora UFMG, 2013; observação de que livros pornográficos foram censurados na ditadura em REIMÃO, Sandra. Censura a livros no Brasil - breve panorama histórico. In: COSTA, Maria Cristina Castilho (Org.). A censura em debate. São Paulo: ECA/USP, 2014, p 113-119; além de trechos que frisam questões morais no Manual Básico da Escola Superior de Guerra citados em OLIVEIRA, Lúcia Maciel Barb osa de. "Nossos comerciais, por favor!": a televisão brasileira e a Escola Superior de Guerra: o caso Flávio Cavalcanti. São Paulo: Beca Produções Culturais, 2001, p. 25.
} 


\subsection{PARTE 1 - UMA PESQUISADE COMUNICAÇÃO Referências teóricas e caminhos metodológicos}

Ainda que apoiada em estudos de diferentes áreas do conhecimento, esta é uma pesquisa de Comunicação, pois seu propósito é mostrar a força simbólica de um produto midiático -a saga de "Roque Santeiro" em seus três atos contra a censura- como revelador de um período histórico do País, a partir da relação entre Dias Gomes, um célebre comunista, o governo militar e a maior emissora de televisão do País.

Quando escolhemos uma telenovela para contar parte da história do Brasil carregamos na bagagem ampla bibliografia a respeito do poder da televisão no País, especialmente desse tipo de teledramaturgia, protagonista da audiência nacional há mais de meio século. E a Escola de Comunicações e Artes da USP, onde realizei minha graduação em jornalismo e que agora dá lugar a este mestrado, reúne grande parcela dos mais relevantes estudos nesse terreno.

Os cruzamentos entre televisão e poder -e a forma como esse veículo de comunicação se impõe como uma representação da sociedade brasileira- são temas de diversos trabalhos de Eugênio Bucci, orientador desta pesquisa, para quem a TV é "muito mais do que um aglomerado de produtos descartáveis destinados ao entretenimento de massa".

No Brasil, ela consiste num sistema complexo que fornece o código pelo qual os brasileiros se reconhecem brasileiros. Ela domina o espaço público (ou a esfera pública) de tal forma que, sem ela, ou sem a representação que ela propõe do País, torna-se quase impraticável a comunicação -e quase impossível o entendimento nacional ${ }^{31}$.

Trilhar parte desse longo caminho percorrido por Bucci -e por outros autores, a exemplo de Renato Ortiz, Maria Rita Kehl e Ester Hamburger- é nosso objetivo, especialmente porque Dias Gomes, "Roque Santeiro" e toda a teledramaturgia do chamado "realismo nacionalista" se posicionam em uma convergência paradoxal entre a ditadura militar e a esquerda oposicionista: ambos interessados em construir uma imagem do Brasil por meio da televisão.

\footnotetext{
${ }^{31}$ BUCCI, Eugênio. Brasil em tempo de TV. São Paulo: Boitempo Editorial, 1997, p. 9
} 
Nossa concepção do triângulo entre Dias Gomes, TV Globo e ditadura se apoia no viés do autor a respeito da idealização de uma nação em meio à indústria cultural:

No Brasil, a nacionalidade se integrou no imaginário por meio da televisão. Esse processo, contudo, já acontece dentro dos marcos da televisão comercial, que opera desde segundo a lógica do consumo. A comunicação própria da sociedade de consumo, voltada estruturalmente para o consumo, chama para si a tarefa de consolidara integração ideológica da nacionalidade, e a realiza, integrando-a também, desde o início numa espacialidade voltada para o consumo ${ }^{32}$.

Estudos de Comunicação evidenciam a possibilidade de se reconstituir a história do País por meio da TV. Afinal, “o palco em que a História acontece é a televisão, uma vez que a espacialidade da televisão adquiriu a prerrogativa de se sobrepor às outras, substituindo-as" ${ }^{\prime 3}$. No Brasil, descreve Bucci, a TV assumiu nos anos 1960 o papel, antes do rádio, de "absorver e precipitar as tendências de comportamento e de identificação em meio ao caldeirão de signos que borbulham no cenário discursivo a que chamamos precariamente de realidade" 34 .

Esse raciocínio é um dos alicerces da construção do objeto deste trabalho, sedimentado por um argumento que Bucci taxativamente resume assim: "Pode-se pensar o Brasil a partir da televisão? Sim, sem dúvida. E talvez não haja mais a possibilidade de pensar o Brasil sem pensar a TV"35.

Quando se volta mais pontualmente às novelas, abre-se outra gama de pesquisas de Comunicação, muitas delas capitaneadas pelo Centro de Estudos de Telenovela (CTVN) da ECA-USP. Coordenadora do CTVN, Maria Immacolata Vassallo de Lopes, ao lado de outros autores, tem colaboração expressiva a desvendar de que forma a telenovela "no Brasil conquistou reconhecimento público como produto artístico e

\footnotetext{
32 Idem. Ubiquidade e instantaneidade no telespaço público: algum pensamento sobre televisão. Revista Caligrama. Revista de Estudos e Pesquisa em Linguagem e Mídia, vol. 2, número 3 - setembro a dezembro de 2006, p. 1

33 Ibidem

${ }^{34}$ Idem. Antropofagia patriarcal. In: BUCCI, Eugênio (org.). A TV aos 50. São Paulo: Editora Fundação Perseu Abramo, 2000, p. 113

35 Ibidem, Introdução
} 
cultural e ganhou visibilidade como agente central do debate sobre a cultura brasileira e a identidade do pais" ${ }^{\prime 36}$.

Entre os anos 60 e 70, a telenovela passou a ser um "fator determinante na criação de uma capacidade televisiva nacional que se projetou não só numa extensiva produção, mas também numa particular apropriação do gênero, isto em, sua nacionalização". O fenômeno se fortalece, no dizer de Martín-Barbero, com a adoção do modelo "moderno" de telenovela, em contraposição ao "tradicional", originado nas radionovelas cubanas -nas quais "prima o desgarramento trágico, o jogo de impulsos e sentimentos primordiais, excluindo do espaço dramático toda a ambiguidade e complexidade históricas". A partir de 1968, com a exibição de "Beto Rockefeller" na TV Tupi, cujo protagonista é um anti-herói, um pobretão que tem por objetivo subir na vida sem muito esforço ${ }^{37}$, a novela brasileira "incorpora um realismo que permite a cotidianização da narrativa e o encontro do gênero com o País tanto para longe, como na amplidão do território, como nos diversos momentos de sua história e transformação industrial"38. E a forma como esse tipo de produção artística se coloca no coração da indústria cultural brasileira -tema central em nosso objeto- é observada por Immacolata com profundidade:

A telenovela também pode ser considerada um dos fenômenos mais representativos da modernidade brasileira, por combinar o arcaico e o moderno, por fundir dispositivos narrativos anacrônicos e imaginários modernos e porter a sua história fortemente marcada pela dialética nacionalização-massmediação ${ }^{39}$.

A pesquisadora se debruça sobre a metodologia das pesquisas de Comunicação e analisa "o progressivo reconhecimento acadêmico da importância da telenovela como objeto privilegiado de estudo sobre a cultura e a sociedade contemporânea brasileira”.

\footnotetext{
${ }^{36}$ LOPES, Maria Immacolata Vassallo. Telenovela brasileira: uma narrativa sobre a nação. São Paulo: Comunicação \& Educação, volume 1, número 26, 2003

37 RAMOS, José Mário Ortiz; BORELLI, Silvia H. Simões. A telenovela diária. In: ORTIZ. Renato; BORELLI, Silvia Helena Simões; RA MOS, José Mário Ortiz. Telenovela - história e produção, $2^{\mathrm{a}}$ edição. São Paulo: Editora Brasiliense, 1991, p. 78

38 Para os modelos "tradicional" e "arcaico" e para Beto Rockefeller, MARTíN-BARBERO, Jesús. Viagens da telenovela: dos muitos modos de viajar em, por desde e com a telenovela. In: LOPES, Maria Immacolata Vassallo (org.). Telenovela - Internacionalização e Interculturalidade. São Paulo: Edições Loyola, 2004, p. 23.

${ }^{39}$ LOPES, Maria Immacolata Vassallo. Telenovela brasileira: uma narrativa sobre a nação. São Paulo: Comunicação \& Educação, volume 1, número 26, 2003
} 
Para Immacolata, "esta situação peculiar alcançada pela telenovela brasileira é responsável pelo caráter, senão único, pelo menos muito peculiar, de uma narrativa nacional, popular e artística". Sua perspectiva sobre as telenovelas e reflexões metodológicas norteiam este estudo.

Não é a essência desta pesquisa realizar uma extensa análise do discurso de " $\mathrm{O}$ Berço do Herói" e "Roque Santeiro". Entretanto, essa prática se torna necessária para algumas reflexões, e temos por referência pesquisadores de Comunicação que estudam a estrutura da telenovela e os meandros do gênero, a exemplo de Maria Lourdes Motter, coordenadora-adjunto do CTVN:

Uma história de amor (romantismo) corre em paralelo com o desenvolvimento de temáticas sociais (realismo) pinçadas na dinâmica da vida social, como questões às vezes embrionárias e nebulosas, marginalizadas como tabus, objetos de proscrição e silêncio, ou difusas como mitos nascentes, objetos de temor, enlevação, encantamento e perplexidade.

(...)

De um lado o fio melodramático, o esquema subjacente de um sujeito em busca de um objeto, com adjuvantes e oponentes, tendo de vencer uma série de obstáculos para alcançar seu objetivo (...), tendendo a um final feliz. De outro, a incorporação com níveis variáveis de enfrentamento, de problemas vividos no contexto da vida cotidiana do indivíduo, da sociedade e do mundo, não superados e não superáveis por não serem colocados como tal, para configurá-los como problemas, dar visibilidade, situá-los e contextualizá-los no espaço da individualidade, da afetividade, das interrelações sociais, do político, do ético e, enfim, do humano. ${ }^{40}$

Outro de nossos eixos é "Telenovela - história e produção", abrangente investigação de Renato Ortiz, em parceria com Silvia Helena Simões Borelli e José Mário Ortiz Ramos, pilar para diversos trabalhos de Comunicação e de outras áreas, ao alinhavar a história da TV e das novelas, inclusive com dados de mercado, ao processo histórico do País:

\footnotetext{
${ }^{40}$ MOTTER, Maria Lourdes. Mecanismos de renovação do gênero da telenovela - empréstimos e doações. In: LOPES, Maria Immacolata Vassallo (org.). Telenovela - Internacionalização e Interculturalidade. São Paulo: Edições Loyola, 2004, p. 259
} 
A partir da virada dos anos 60/70, a telenovela se encontra imersa num processo cultural cada vez mais atravessado pelos influxos modernizadores da sociedade e coercitivos do Estado autoritário.

Complexificação da sociedade e produção de cultura voltada para um amplo mercado de bens simbólicos são marcas deste novo período. Momento de consolidação definitiva da televisão brasileira enquanto indústria. O número de aparelhos, que, como vimos, tem um avanço significativo no decênio anterior, cresce agora em rápida progressão:4,9 milhões em 1970; 10,2 milhões em 1975; 19,6 milhões em 1980 (dados ABINEE). O investimento publicitário também encontra na televisão o seu veículo prioritário: 1970 $36,7 \% ; 1976-40,2 \% ; 1979-49 \% ; 1982-51,6 \%{ }^{41}$.

Traçando a trajetória de cada uma das emissoras de TV, os pesquisadores jogam luz na consolidação da Globo -e de suas telenovelas- durante a ditadura, o que nos interessa fortemente:

A Globo não se adequa exclusivamente às transformações sócioeconômicas por que passa a sociedade brasileira, ela também se sintoniza com a ação estatal. Des de o governo Castello Branco, o Estado autoritário passa a se preocupar com os assuntos de cultura, procurando realizar diretrizes que favoreçam o desenvolvimento de uma "cultura brasileira", de uma "identidade nacional" compatível com suas premis sas coercitivas. Esta movimentação estatal, combinando censura e incentivo no plano econômico, já foi devidamente analisada. Nos interessa aqui vincular esta atmosfera político-cultural com a televisão, e particularmente com a telenovela. ${ }^{42}$

Ao observar a interseção entre política e entretenimento, apontam para a apropriação da TV por um ideário politizado, com intenções revolucionárias, em que os escritores, entre eles Dias Gomes, acreditavam na "possibilidade de se trabalhar junto a um gênero popular, visando a uma 'conscientização' mais elaborada (...) o que seria alcançado através dos conteúdos das novelas com as questões mais amplas do processo

\footnotetext{
${ }^{41}$ RAMOS, José Mário Ortiz; BORELLI, Silvia H. Simões. A telenovela diária. In: ORTIZ. Renato; BORELLI, Silvia Helena Simões; RA MOS, José Mário Ortiz. Telenovela - his tória e produção, $2^{\mathrm{a}}$ edição. São Paulo: Editora Brasiliense, 1991, p. 80-81 42 Ibidem, p. 82, citando MOSTAÇO, Edélcio. O espetáculo autoritário. São Paulo: Proposta Editorial, 1983; ORTIZ, Renato. Cultura brasileira e identidade nacional. São Paulo: Brasiliense, 1985; RAMOS, José Mário Ortiz. Cinema, Estado e lutas culturais. Rio de Janeiro: Paz e Terra, 1983.
} 
cultural e político" ${ }^{\prime 4}$. Ou seja, se, por um lado, a telenovela construía a unidade nacional pretendida pelos militares, por outro, dava espaço a intenções revolucionárias -enquanto gerava lucros astronômicos para a emissora de televisão.

Nesse contexto entra em cena a proibição a "Roque Santeiro", em 1975. O estudo da censura é certamente multidisciplinar -abarcado em especial pela História e pela Sociologia, além da própria Comunicação. Sem se limitar às fronteiras dos campos do conhecimento, esta pesquisa tem como um de seus pontos de partida o debate conduzido pelo Observatório de Comunicação, Liberdade de Expressão e Censura (Obcom), da ECA-USP, coordenado por Maria Cristina Castilho Costa. O núcleo foi iniciado na sequência da organização do Arquivo Miroel Silveira, que reúne mais de 6.000 processos de censura prévia ao teatro paulista, e se tornou um dos principais centros de reflexão sobre censura e liberdade de expressão da América Latina. Carrega a importante bandeira de frisar que a censura não é restrita a períodos ditatoriais, e que age das mais variadas formas, longe de estar limitada ao Estado.

A censura é, provavelmente, um processo psicossocial tão antigo quanto o desenvolvimento da capacidade simbólica do ser humano, pois, desde os primórdios da cultura, estabeleceu-se o conflito entra uma subjetividade única e indivisível que nos distingue como individualidade e a força hegemônica da cultura forjada nas relações estabelecidas na vida coletiva. A oposição entre o eu e o outro, entre sujeito e cultura, as sim como entre diferentes grupos dentro de uma mesma cultura, tem levado a sucessivas tentativas de repressão das dissidências, das críticas e das insubordinações, com o uso de diferentes recursos de autoritarismo e violência. $^{44}$

São considerações indispensáveis para evitar que nosso objeto -ao fazer um recorte da história do Brasil a partir dos três momentos de "Roque Santeiro" (1965, 1975 e 1985)- passe a falsa impressão de que a censura no País é uma consequência da ditadura. Nossa intenção, ao contrário, é mergulhar na repressão a essa obra justamente para reforçar a noção de que o cerceamento à liberdade de expressão é uma prática, com

\footnotetext{
43 ORTIZ, Renato; BORELLI, Silvia Helena Simões; RAMOS, José Mário Ortiz. Telenovela - his tória e produção, 2a edição. São Paulo: Editora Brasiliense, 1991, p. 80-90

${ }^{44}$ COSTA, Maria Cristina Castilho. Opinião pública, comunicação, liberdade de expressão e censura. In: COSTA, Maria Cristina Castilho (Org.). A censura em debate. São Paulo: ECA/USP, 2014, p. 27
} 
o perdão da ironia, ampla, geral e irrestrita. O estudo desse caso elucida de que modo arcabouço legal da censura se constrói inclusive em períodos democráticos e como a repressão à cultura tem tentáculos diversos -pode vir do Estado, das forças políticas de oposição, da Justiça, do poder econômico, da Igreja, da própria sociedade...

O diário de Dias Gomes que apresentamos nesta dissertação aponta para a desaprovação de um personagem de uma de suas peças, "A Invasão”, pelo Partido Comunista. O autor não fala em censura, e sempre negou intervenção do PCB em seu trabalho, mas, com outros artistas, até mesmo com alguns de seus amigos próximos, como Jorge Amado e Oduvaldo Vianna, isso não era raro -a direção partidária inventava personagens, matava outros e chegava a vetar obrar inteiras, em consonância com a caneta pesada da ditadura soviética ${ }^{45}$. Assim, a censura se mostra suprapartidária, disseminada "democraticamente", da direita à esquerda, porque visa o controle do poder para qualquer que seja a tendência política. Acreditamos dar uma colaboração a essa ideia, em particular, ao esclarecer que a versão de "Roque Santeiro" 1985, que ficou para a história como a novela da redemocratização, foi seguidamente censurada em um período já democrático.

É importante também pontuar que o veto total a "Roque Santeiro" em 1975, apesar de ter feito da novela um símbolo da repressão, não é exemplar do que acontecia na época. Foi, por sinal, um fato único até aquele momento e que só seria repetido em toda a história da TV no ano seguinte, com "Despedida de Casado"46, também na Globo. Pode ser visto como uma quebra na constante relação de negociação e tensão entre as TVs e a censura, que demonstrava preferência por modificar, no lugar de proibir totalmente, até para obrigar os produtores culturais, e igualmente as emissoras de televisão, a uma contínua e forçosa busca por arranjos, num estado de permanente

\footnotetext{
${ }^{45}$ Para os vetos e intervenções do PCB, Ver MORAES, Dênis. O imaginário vigiado - a imprensa comunista e o realis mo socialista no Brasil. Rio de Janeiro: José Olympio Editora; para a ditadura soviética, PERALVA, Osvaldo. O retrato. São Paulo: Três Estrela, 2015.

${ }^{46}$ Para "Despedida de Casado", ver SIMÕES, Inimá. Nunca fui santa (episódios de censura e autocensura). In: BUCCI, Eugênio (org.). A TV aos 50. São Paulo: Editora Fundação Perseu Abramo, 2000, p. 46.
} 
“débito" com o poder governamental ${ }^{47}$-situação que fazia dos censores "parceiros" compulsórios dos novelistas e que facilitava o advento da autocensura ${ }^{48}$.

Não se pode ignorar ainda que as telenovelas tenham sofrido menos com a censura do que outros tipos de programas de TV, do telejornalismo aos shows populares de auditório -e isso se devia em grande parte ao prestígio dos autores e ao poder de faturamento das novelas, além do formato seriado, que facilitava ajustes exigidos pela Censura ao longo dos capítulos ${ }^{49}$. Ainda que um ponto fora da curva, ou mesmo até por isso, a proibição de "Roque Santeiro" deve ser desvendada em razão do seu valor simbólico na história da TV e do País e, conforme nossa hipótese, por se tratar de um obra em três atos, que traz à tona o início, o meio e o fim da ditadura militar.

A escolha desse objeto está longe de pressupor que a censura à telenovela ou à televisão tenham sido mais dramáticas ou importantes do que a outros produtos culturais, como livros, música, o teatro (esse último também analisado nessa dissertação, a partir do veto a "O Berço do Herói’) e mesmo à imprensa. Trata-se de um enfoque, sem menosprezar o panorama do amplo cerceamento.

Intencionamos contribuir para um lado da censura ainda parcamente explorado. Nahuel Ribke ${ }^{50}$, professor de História e Cultura da América Latina na Universidade de Tel Aviv, com pertinente estudo sobre a censura na TV brasileira durante a ditadura militar, afirma que, apesar da "enorme popularidade e grande impacto na vida pública", a televisão no período é pouco estudada, uma vez que a academia demonstra predileção por investigar a censura no teatro, na música popular e na imprensa. Para Ribke, isso

\footnotetext{
${ }^{47}$ As observações sobre a preferência por modificar e o motivo para isso foram colocados em banca de qualificação desta pesquisa por Maria Cristina Castilho Costa e constam de uma de suas palestras, fornecida para esta dissertação.

${ }^{48}$ Para a autocensura na TV ver SIMÕES, Inimá. Nunca fui santa (episódios de censura e autocensura). In: BUCCI, Eugênio (org.). A TV aos 50. São Paulo: Editora Fundação Perseu Abramo, 2000, p. 46; KUSHNIR, Beatriz. Cães de Guarda - Jornalistas e censores do AI-5 à Constituição de 1988. São Paulo: Boitempo, 2004, p. 311; e CLARK, Walter, com PRIOLLI, Gabriel. O campeão de audiência - uma autobiografia. São Paulo: Editora Best Seller, 1991, p. 199

${ }^{49}$ A análise de que a censura de "Roque Santeiro" é uma exceção e as considerações sobre as especificidades do controle às telenovelas estão em diferentes artigos de Nahuel Ribke. Os consultados para esta pesquisa foram: Telenovela writers under the military regime in Brazil: Beyond the cooption and resistance dichotomy (Media, Culture \& Society, 2011); Decoding television censorship during the last brazilian military regime - The censor as negotiator and censorship as a semi-open interpretative process (Media History, vol 17, n. 1. 2011); The genre of live studio audience programmes in a political contexto: The Flavio Cavalcanti Show and de brazilian military regime (Screen, vol. 54, ed. 3, 2013) e The brazilian military regime and television censorship: between the internal logics of production and the political context (Revista de História, n. 169, 2013).

${ }^{50}$ As referências a RIBKE, Nahuel se referem ao artigo $\mathbf{O}$ regime militar brasileiro e as censuras televisivas: Entre as lógicas internas de produção e o contexto político. In: Revista de História, $\mathrm{n}^{\mathrm{0}} 169$, São Paulo (2013); tradução nossa.
} 
pode se dever à "posição ambígua" da TV, "interpretada por um lado como totalmente alienada e funcional ao regime militar e, por outro, como supérflua e irrelevante para entender a realidade política e social daqueles anos".

Obviamente essa visão, equivocada, tem mudado. E Ribke defende que os arquivos que envolvem a televisão na Divisão de Censura e Divertimento Público (DCDP) -onde esta pesquisa levantou os registros sobre "Roque Santeiro"- são fontes quase inexploradas, "que, ao mesmo tempo que nos revelam aspectos mais cotidianos da censura, deixam descobertos um entremeado de negociações, tensões e conflitos pouco estudados nos últimos anos".

Os 20 anos sobre os quais nos lançamos -entre a censura de "O Berço do Herói”, em 1965, na fase inicial do regime militar, e a veiculação de "Roque Santeiro", em 1985, ano do término da ditadura- delimitam a construção de nosso objeto. Isso não quer dizer que tenhamos ignorado o processo histórico que criou as condições para o caso investigado, nem que desconsideremos o fato de a censura ter persistido no País e no mundo, estando hoje no topo das discussões sobre a internet -afinal, como observou Bucci, se por um lado a rede mundial de computadores "horizontaliza a possibilidade de emissão [de conteúdo] e dá a cada ser humano conectado o poder de ser mídia", por outro, paradoxalmente, apresenta um "concentração de capital nunca vista até aqui", com controle de conteúdo exercido a partir do poder econômico, com grandes empresas como Google e Facebook decidindo o que pode e o que não pode circular ${ }^{51}$.

As telenovelas, mais de 30 anos depois que a Viúva Porcina tomou um jatinho para fugir com Sinhozinho Malta de Asa Branca, na cena final de "Roque Santeiro", seguem sendo forçosamente modificadas pelo mecanismo da classificação indicativa por faixas etárias, que substituiu a censura na Constituição de $1988^{52}$.

Aqui, ilustramos esse impasse com uma passagem no mínimo curiosa, quando, em 2007, Aguinaldo Silva teve que explodir um bar em que dançarinas faziam "pole dancing”, em "Duas Caras", para que a novela não fosse reclassificada para um horário mais tarde. À época, em seu blog, o autor relacionou o episódio à censura, lembrando que em 1985, apesar de haver o controle censório "oficial", não foi preciso acabar com

\footnotetext{
${ }^{51}$ BUCCI, Eugênio. Censura, marcos regulatórios e tecnologia. In: COSTA, Maria Cristina Castilho (Org.). A censura em debate. São Paulo: ECA/USP, 2014, p. 155

52 Mayra Rodrigues Gomes tem um amplo trabalho sobre classificação indicativa no Obcom. Entre outros textos, temos aqui como referência: Algumas considerações sobre a classificação indicativa. In: COSTA, Maria Cristina Castilho (Org.). A censura em debate. São Paulo: ECA/USP, 2014, p. 127-131.
} 
a boate "Sexus", de "Roque Santeiro", da qual foi coautor. E encerrou, irônico: "Hoje todos nós criadores devemos dar graças aos céus, pois vivemos num governo democrático, cujos líderes lutaram bravamente contra as arbitrariedades de então, e, por isso, jamais admitiriam o retorno desse estado de coisas" ${ }^{\prime 53}$.

"Inscrever na ordem do dia a multidisciplinaridade." A frase, de Mattelart ${ }^{54}$, resume nossa intenção de trabalhar nesta pesquisa com outros campos, aliados à Comunicação. Tivemos especial apoio da história (com foco na obra de Napolitano) e da sociologia, mais precisamente na sociologia da cultura (Ridenti). Como nos lembra Muniz Sodré ${ }^{55}$, para a interpretação das relações econômicas, políticas e sociais entre o que ele chama de "dispositivo comunicativo" e a sociedade, é preciso "convocar o saber das disciplinas clássicas do pensamento social", entre elas a história e a sociologia.

É vital que a abordagem tenha como pano de fundo uma ruptura com o senso comum, que muitas vezes se apoia em análises simplistas sobre a relação entre Dias Gomes e a Globo. Um dos grandes nomes da intelectualidade do Partido Comunista, o autor vivia sob a aparente contradição entre suas crenças ideológicas e o trabalho na Globo. Sobre esse aspecto, vale lembrar a discussão sobre identidade feita por Stuart Hall56, para quem as "divisões e antagonismos" da sociedade moderna produzem "uma variedade de diferentes 'posições de sujeito' -isto é, identidades- para os indivíduos".

Nesse "jogo de identidades", há "identidades contraditórias", em que as contradições atuam tanto "fora, na sociedade, atravessando grupos políticos estabelecidos, quanto 'dentro' da cabeça de cada indivíduo”.

A análise desse rumoroso caminho político de Dias Gomes nos veículos de comunicação foi objeto de detalhada pesquisa de doutorado de Igor Sacramento ${ }^{57}$, também do campo da história, que nos serve de indispensável aparato. Ele nos aponta

\footnotetext{
${ }^{53}$ MATTOS, Laura. Governo decide subir classificação de "Duas Caras" para 14 anos. Folha de S.Paulo, 20/12/2007, p. A13

${ }^{54}$ MATTELART, Armand; apud. LOPES, Maria Immacolata Vassallo de. Sobre o estatuto disciplinar do campo da Comunicação. In: LOPES, Maria Immacolata Vassallo de (org.). Epistemologia da Comunicação. São Paulo: Loyola, 2003, p. 277

55 SODRÉ, Muniz. Sobre a episteme comunicacional. MATRIZes, 1, Ano 1, 2007

${ }^{56}$ HALL, Stuart. A identidade cultural na pós-moderni dade. Rio de Janeiro: DP\&A, 1999, p. 20

57 SACRAMENTO, Igor Pinto. Nos tempos de Dias Gomes - A Trajetória de um intelectual comunista nas tramas comunicacionais, doutorado na UFRJ, 2012
} 
que o autor, "como mediador cultural, não apenas lidou com diferentes códigos e papéis sociais, num intenso processo de metamorfose e de hidridização, mas, principalmente, estabeleceu 'pontes ou canais de comunicação' entre diferentes campos sociais" ${ }^{\prime 58}$.

A própria visão em relação à Globo deve romper com o senso comum, assim como com parte da corrente acadêmica de esquerda, que, como observou Enzeberger ${ }^{59}$ em 1970, "reduziu o desenvolvimento da mídia a um simples conceito -o de manipulação". Como fica a noção da "TV oficial da ditadura" diante da censura de "Roque Santeiro"?

Para isso, além dos autores já mencionados, trabalhos de Ridenti e de outros pesquisadores sobre a esquerda política brasileira e as classes artística e intelectual será de vital importância. Dos diversos trabalhos de Ridenti, destaco dois que moderam este trabalho: os livros "Brasilidade revolucionária"60 e "Em busca do povo brasileiro artistas da revolução, do CPC à era da TV"61. Ridenti fala da relação dos artistas e intelectuais com o Partido Comunista e com a indústria cultural.

A busca da ligação política do artista com seu público (...) tenderia a ser cada vez mais mediada pelo mercado. Assim, os aspectos questionadores iam-se diluindo diante da poderosa indústria cultural que ser firmava, até mes mo criando um lucrativo mercado de contestação à ordem estabelecida. Muitos dos cineastas, compositores da canção popular, atores, dramaturgos e outros artistas contestadores nos anos 1960 viriam a fazer sucesso, por exemplo, na maior instituição da industrial cultural brasileira atual: a Rede Globo de Televisão. ${ }^{62}$

Dias Gomes, ao longo de sua vida, concedeu diversas entrevistas, escreveu artigos e publicou sua biografia. Mas a herança de seu discurso, contudo, também encontra-se fragmentada. Pincelar declarações do dramaturgo de forma organizada a fim

\footnotetext{
${ }^{58}$ Citação a VELHO, Gilberto. Biografia, trajetória e mediação", In: SACRAMENTO, Igor Pinto. Nos tempos de Dias Gomes - A Trajetória de um intelectual comunista nas tramas comunicacionais, doutorado na UFRJ, 2012, p. 15.

${ }^{59}$ Citação a artigo de ENZENSBERG, Hans Magnus, publicado na News Left Review. In: MATTELART, Armand e MATTELART, Michèle. História das teorias da Comunicação. São Paulo: Loyola, 1998, p. 99.

${ }^{60}$ RIDENTI, Marcelo. Brasilidade revolucionária. São Paulo: Editora Unesp, 2010

${ }^{61} \mathrm{Idem}$. Em busca do povo brasileiro - artistas da revolução, do CPC à era da TV. Rio de Janeiro: Record, 2000

${ }^{62}$ Idem. Brasilidade revolucionária. São Paulo: Editora Unesp, 2010, p. 143
} 
de costurar um pano de fundo para a análise de "Roque Santeiro", em seus três atos, foi um dos objetivos deste trabalho.

Foi desafiador mergulhar no vasto corpus obtido. Para isso, nos ajudou Cellard, com seu artigo "A Análise Documental"63. Como ele defende, se, por um lado, os documentos apresentam a vantagem de influências na interação entre o pesquisador e o pesquisado, por outro, "a informação, aqui, circula em sentido único; pois, embora tagarela, o documento permanece surdo, e o pesquisador não pode dele exigir precisões suplementares". Vê-se daí a clara necessidade de se cruzar as informações documentais com outros métodos de pesquisa, como entrevistas e leitura da imprensa ou de outras fontes. Cellard também alerta para os "obstáculos e armadilhas" de se trabalhar com documentos, que antes devem ter sua "credibilidade e representatividade" postos à prova. É um pensamento de extrema importância para a nossa pesquisa, que trabalha com muitos documentos de períodos de censura e, no caso dos depoimentos, colhidos sob coerção e tortura. "O exame do contexto social global no qual foi produzido o documento e no qual mergulhava seu autor e aqueles a quem ele foi destinado é primordial", lembra Cellard, que complementa: "Não se pode pensar em interpretar um texto sem ter previamente uma boa ideia da identidade da pessoa que se expressa, de seus interesses e dos motivos que o levaram a escrever".

Esta dissertação está dividida em três partes, chamadas de "atos", que miram as três passagens da saga dessa obra de Dias Gomes contra a censura. O primeiro ato, com “O Berço do Herói”, o segundo, da primeira versão de "Roque Santeiro", e o terceiro, a respeito da novela exibida. A narrativa segue, na maior parte do trabalho, ordem cronológica, de forma a mostrar a evolução dos acontecimentos e encadear as mudanças na política e na censura.

A peça foi escrita em 1963, mas nosso texto volta dez anos na história, a fim de possibilitar contextualização sobre a vida e a obra de Dias Gomes. Assim, está também incluído no primeiro ato um capítulo a respeito do diário do escritor, com registros de 1959 a 1962. É o período em que o autor define sua trajetória artística, e registra esse movimento nas confidências desse valioso e até agora inédito documento. Entender os caminhos da concepção de "O Pagador de Promessas" e da peça feita na sequência, "A

\footnotetext{
${ }^{63}$ CELLARD, André. A análise documental. In: A pesquisa qualitativa. Enfoques epistemológicos e metodológicos. Petrópolis: Vozes, 2008, p 295-314
} 
Invasão", é conhecer o DNA de Roque, Sinhozinho Malta, Viúva Porcina e toda Asa Branca, a cidade cenário de nossa obra-objeto.

A intenção foi que o objeto fosse "bem construído" (Bourdieu) para que "deixe de ser particular e possa contribuir com o conhecimento. Como um estudo de caso, não nos interessamos unicamente pelas especificidades do caso em questão (ainda que elas possam ser valorizadas e importantes), mas também por sua capacidade de servir de via de acesso a outros fenômenos ou a outros aspectos da realidade".

Os três atos de "Roque Santeiro" podem ser considerados um "modelo societário de objeto", na categorização de Pires, em que "o pesquisador orienta seu olhar do sentido inverso do precedente: em lugar de ter em mente certos comportamentos que ele quer compreender ou explicar, ele parte (...) do estudo de um meio ou acontecimento para apreender determinados aspectos da organização social, das instituições ou da cultura". Assim, a saga de "Roque Santeiro" contra a censura pode nos contar parte da história do Brasil nesse mesmo período. Ao olhar para a obra, queremos enxergar os meandros da ditadura militar. "O pensamento adota, aqui, um movimento centrífugo: a compreensão do caso, enquanto tal, cede lugar a um conhecimento mais geral do que o próprio caso" ${ }^{\prime 64}$.

No processo de construção do objeto houve incessante reflexão sobre como se daria a escrita da dissertação. Com 20 anos de trabalho em Redações de jornais diários, seria inevitável que o estilo jornalístico aflorasse. Em um primeiro momento, evitá-lo parecia ser o desafio, buscando uma linguagem mais próxima do que se costuma adotar na academia. A leitura de trabalhos sobre metodologia em pesquisa de Comunicação nos fez crer que sufocar a tinta jornalística seria apagar o sujeito da pesquisa, o que não é desejável em tempos em que a epistemologia contemporânea valoriza até mais o olhar do que o próprio objeto. No dizer de Said, "nenhuma produção de conhecimento nas ciências humanas pode jamais ignorar ou negar o envolvimento de seu autor como sujeito humano em suas próprias circunstâncias" $" 65$.

Esta pesquisa nasceu a partir de uma experiência como jornalista em um caderno de cultura ("Ilustrada") e em um período sabático concedido por um jornal ("Folha de S.Paulo"), com uma primeira intenção de se transformar, como dito anteriormente, em

\footnotetext{
${ }^{64}$ Para a categorização do modelo do objeto, ver PIRES, Álvaro P. Amostragem e pesquisa qualitativa: ensaio teórico e metodológico. In: POUPART, Jean et al. A pesquisa qualitativa - Enfoques epistemológicos e metodológicos. Petrópolis: Vozes, 2008, p. 154-210.

${ }^{65}$ SAID, Edward. Orientalis mo. São Paulo: Companhia das Letras, 1990, p. 23
} 
livro-reportagem. Deixar que o jornalismo e suas técnicas de apuração e escrita convivam com esta dissertação, buscando níveis de rigor e de reflexividade condizentes com academia, é ser honesto com o leitor e com o próprio objeto.

E, para encerrar esta introdução, cito trecho de Bourdieu, de "A ilusão biográfica", destacado por Kushnir para descrever a complexidade de se estudar os censores. Aqui, o raciocínio do sociólogo se aplica ao tão intrincado papel que o comunista Dias Gomes e sua obra tiveram nessa relação triangular com a maior emissora de TV do País e a ditadura militar:

Compreender uma vida como uma série única e por si suficiente de acontecimentos sucessivos, semoutro vínculo que não a as sociação a um “sujeito" cuja constância certamente não é senão aquela de um nome próprio, é quase tão absurdo quanto tentar explicar a razão de um trajeto de metrô sem levar em conta a estrutura da rede, is to é, a matriz das relações objetivas entre as diferentes relações. 66

Que esta pesquisa possa, então, colocar os três atos de "Roque Santeiro" no trilho da história.

${ }^{66}$ BOURDIEU, Pierre. A ilusão biográfica, em Ferreira e Amado, op. Cit. Cap. 13. In: KUSHNIR, Beatriz. Cães de Guarda - Jornalistas e censores do AI-5 à Constituição de 1988. São Paulo: Boitempo, 2004, p. 60 


\section{PRIMEIRO ATO}

Morto no nascimento

"O Berço do Herói" 


\subsection{Capítulo 1}

\section{Encontro com Carlos Lacerda}

Carlos Lacerda não se deu conta de que tinha pólvora nas mãos. No dia 18 de maio de 1953, seu jornal, "A Tribuna da Imprensa", publicou sem destaque uma foto enviada pela agência oficial de notícias soviética. No canto direito da página 5 , a imagem, em apenas duas colunas, abria a seção "O Pequeno Mundo”, de notas internacionais, com uma legenda inofensiva: "Uma delegação de trabalhadores e partidários da paz do Brasil, em visita a Moscou, colocou coroas de flores no Mausoléu da Praça Vermelha".

Só duas semanas depois, em meio aos tais partidários da paz da fotografia, Lacerda identificou Alfredo Dias Gomes. Fosse ele apenas mais um autor teatral subversivo em início de carreira, vá lá, mas o homem era diretor de programação da Rádio Clube, propriedade de seu arqui-inimigo Samuel Wainer.

A fotografia merecia ser promovida. Na edição de 27 de maio, ela voltou ao jornal, agora em três colunas e na primeira página, quase integralmente dedicada a atacar Wainer. "Diretores da Rádio Clube levam flores ao túmulo de Stalin", dizia o título. O texto afirmava que, na imagem, do "bando de Samuel Wainer", foram identificados Dias Gomes, diretor da rádio, e Cláudio Santoro, diretor musical. "Vale dizer que Dias Gomes detém o posto chave da rádio, que todos os dias manda ao ar programas de ódio social". Mais grave: "A quinta coluna do rádio brasileiro"67, bradava a "Tribuna", viajou a Moscou financiada pelo Banco do Brasil.

A excursão brasileira ao $1^{\circ}$ de Maio soviético desembarcava em uma guerra da imprensa carioca que tinha, de um lado, Lacerda, e, do outro, Samuel Wainer e Getúlio Vargas. O texto sobre a viagem era parte de uma série de reportagens que acusavam Wainer de formar seu grupo de comunicação graças a financiamentos do Banco do Brasil, facilitados pelo presidente, em troca de apoio político.

Além da Rádio Clube e da então recém-lançada revista "Flan", Wainer era dono do diário "Última Hora". Fundado em 1951 como um vespertino carioca, no ano

\footnotetext{
${ }^{67}$ Ver SACRAMENTO, Igor Pinto. Nos tempos de Dias Gomes - A Trajetória de um intelectual comunista nas tramas comunicacionais, doutorado na UFRJ, 2012, p. 127: "A expressão 'quinta coluna' é usada para designar a presença de um grupo dentro de um país, uma região ou uma instituição que atenda aos princípios de outra ordem, opositora aos que são vigentes e afinada com os que emergem de fora. Nesse caso aqui, está a denúncia da in filtração comunista na rádio".
} 
seguinte já circularia em São Paulo e, no auge, chegaria a uma distribuição nacional, com sede própria em sete Estados. Tornara-se, assim, o maior concorrente da "Tribuna"68, que Lacerda lançara em 1949 no Rio de Janeiro, após conseguir angariar fundos com a ajuda de influentes amigos católicos, como Alceu Amoroso Lima, Gustavo Corção e Sobral Pinto ${ }^{69}$.

Em meados de março daquele ano, Dias Gomes recebera o convite para se unir à comitiva de Moscou, organizada por Jorge Amado, seu companheiro do Partido Comunista. Conterrâneos, eles se conheciam dos tempos em que Dias ainda morava na sua cidade natal, Salvador, quando seu irmão mais velho, Guilherme, e Amado formaram a autointitulada Academia dos Rebeldes, uma tentativa juvenil de se contrapor à Academia Brasileira de Letras $^{70}$.

A proposta de viajar à capital soviética deixou Dias em um dilema: ele tinha, de um lado, seu patrão pró-Vargas e, de outro, o PCB, que, com suas lógicas paradoxais e complexas, estava naquele momento aliado a Lacerda na campanha para depor o presidente. O jovem comunista preferiu enganar o chefe e topou ir a Moscou, inventando que faria uma viagem de estudos à Inglaterra. Para cruzar a Cortina de Ferro endividou-se -não com o Banco do Brasil, como denunciava a "Tribuna", mas com um agiota.

Diante da repercussão da reportagem do jornal de Lacerda, Wainer mandou demiti-lo, assim como a Santoro. Quem cumpriu a ordem foi o diretor comercial, Marques Rebelo, simpatizante do Partido. A emissora, como quase todas as outras, era coalhada de comunistas. Dias havia contratado pecebistas como o próprio Cláudio Santoro, músico clássico com quem ele dividira o quarto em Moscou, e o ator Mário Lago, seu companheiro nas noites de boemia ${ }^{71}$.

Tinha como estagiário um garoto de 18 anos também ligado ao $\mathrm{PCB}$, que não saía de seu pé o dia inteiro e fora empregado a pedido de José Hernandes, que editara um romance de Dias, "Duas Sombras Apenas", em 1945: José Bonifácio de Oliveira

\footnotetext{
68 Para a disputa entre Wainer e Lacerda ver LAURENZA, Ana Maria de Abreu. Lacerda X Wainer - O Corvo e o Bess arabiano. São Paulo: Senac, 1998.

${ }^{69}$ Para a informação sobre a ajuda a Lacerda, FRIAS FILHOS, Otavio. O tribuno da imprensa. Revista Piauí, n. 91, 4/2014, disponível em http://piaui.folha.uol.com.br/materia/o-tribuno-da-imprensa/ (acesso em 22/6/2016).

${ }^{70}$ GOMES, Dias. Apenas um subversivo. Rio de Janeiro: Bertrand Brasil, 1998, p. 23

${ }^{71}$ SACRAMENTO, Igor Pinto. Nos tempos de Dias Gomes - A Trajetória de um intelectual comunista nas tramas comunicacionais, doutorado na UFRJ, 2012, p. 128
} 
Sobrinho. Conhecido como Boni, chegou a participar de um congresso comunista em Praga. Havia sido levado à militância pelo radialista e pioneiro da TV Túlio de Lemos, mas sua filiação terminaria não muito depois, aos 20 e poucos anos -decepcionou-se com membros que the solicitaram espaço para a propaganda de uma exposição iugoslava em rádios e que queriam não um preço mais barato, para o Partido economizar, mas mais alto para dividirem a margem de superfaturamento ${ }^{72}$.

Entre um programa e outro, os estúdios da Rádio Clube eram usados para reuniões políticas e, tarde da noite, funcionários assistiam a filmes rejeitados pelo circuito comercial, muitos deles soviéticos, em um cineclube organizado por Luiz Alípio de Barros, crítico de cinema do jornal "Última Hora"73.

Apesar de disseminada, a prática devia se manter o mais sigilosa possível. O ano de 1953 foi para lá de turbulento. Em 5 de janeiro, era assinada uma nova Lei de Segurança Nacional, mais ampla e severa do que a que revogava, a primeira da república brasileira, de 1935. A nova legislação tornava crimes e punia com cadeia greves e qualquer movimento de crítica ao poder constituído, como a "incitação à luta de classes".

O mundo estava em Guerra Fria, e o Brasil vivia um caos político, com a divisão dos militares e a tentativa de deposição de Getúlio liderada por Lacerda, quando Dias Gomes não só perdeu o emprego como entrou na "lista negra" da radiodifusão. Para um jovem dramaturgo apaixonado pelo teatro, ser vetado nas rádios aumentava seu fardo com esse tipo de trabalho, que já fazia sem prazer e só pela sobrevivência financeira.

Do ponto de vista pessoal, aquela também era uma hora especialmente errada para ficar desempregado, endividado com um agiota e ter o nome incluído na lista dos profissionais vetados. Janete Clair, com quem se casara em 1950, havia interrompido a carreira de locutora e atriz de radionovelas no ano anterior, quando perdera um filho com poucas semanas -ela era Rh negativo, e Dias, positivo; o bebê herdara o sangue do pai, os anticorpos da mãe reagiram contra ele, e a medicina tinha então poucos recursos para evitar sua morte prematura causada pela chamada eritroblastose fetal.

\footnotetext{
72 Entrevista de Boni à autora, no Rio, em 12/9/2011.

${ }^{73}$ Depoimento à autora, em 29/3/2011, do jornalista Henrique Veltman, que militava com Dias Gomes no Partido Comunista, foi seu contemporâneo nas radionovelas e irmão de Moysés Weltman, amigo do escritor, que cedeu seu nome para assinar textos de Dias para o teatro e para a TV Tupi quando ele entrou na "lista negra", após o episódio da Rádio Clube.
} 
Para piorar, o casal havia acabado de obter um empréstimo bancário a fim de comprar o primeiro apartamento da família, na rua Senador Vergueiro, no Flamengo, onde morava com o primogênito, Guilherme, de três anos, e com a mãe de Dias, dona Alice. Com a demissão da Rádio Clube, o escritor devolveu o imóvel e voltou para o aluguel, em uma casa na rua Saturnino de Brito, no Jardim Botânico ${ }^{74}$.

O teatro, que abandonara quase dez anos atrás - desiludido com a preferência do mercado pelas comédias, com a resistência a uma estética mais realista e nacional e com vetos políticos a seus textos-, estava obviamente descartado para um integrante da lista negra. Uma pena, pois os palcos estavam fervilhantes. Naquele ano nascia o Teatro de Arena, que se iniciou com o grupo da Escola de Artes Dramáticas de São Paulo e tinha o objetivo de se contrapor ao modelo do TBC, o Teatro Brasileiro de Comédia, focado em produções mais caras e em textos estrangeiros. O Arena logo se tornaria um centro de arte engajada, que, conforme analisou Miliandre Garcia de Souza, contribuiu para "a introdução da problemática nacional-popular em determinadas linguagens artísticas e, sobretudo, para a organização da intelectualidade de classe média em torno das palavras de ordem e das estratégias de luta política e ideológica da época"75.

A essa turma, Dias Gomes só iria se juntar depois. Naquelas circunstâncias, restava-lhe a televisão, tão sem prestígio, instalada havia três anos no País -a TV Tupi fora inaugurada em São Paulo, em setembro de 1950, na primeira transmissão da América Latina. Com recursos mínimos, não muito atrativo para o mercado publicitário, o veículo mantinha poucos profissionais com contrato e, quando precisava, comprava textos de roteiristas. Dias fez seus primeiros trabalhos para a Tupi do Rio com pseudônimo. Para assinar suas criações para o teatro de comédia e de polícia da TV, usou o nome da mulher, de seu ex-assistente na Rádio Clube, Paulo de Oliveira, e do amigo do Partido Comunista Moysés Weltman ${ }^{76}$. Em uma verdadeira "farra de troca de nomes", assinou, por exemplo, como Wanda Wladimir, inspirado nos nomes dos dois filhos de Moyses $^{77}$. Quando os amigos recebiam o pagamento, "miserável", ia Dias a suas casas para buscar o dinheiro. Assim seria por nove meses, até ele ter um programa

\footnotetext{
74 GOMES, Dias. Apenas um subversivo. Rio de Janeiro: Bertrand Brasil, 1998, p. 145 75 SOUZA, Miliandre Garcia de. Do Arena ao CPC: o debate em torno da arte engajada no Brasil (1959-1964), mestrado da Universidade Federal do Paraná, 2002, p. 146 76 Depoimento à autora de Henrique Veltman e GOMES, Dias. Apenas um subversivo. Rio de Janeiro: Bertrand Brasil, 1998, p. 147.

77 As informações e a expressão "farra na troca de nomes" são de Henrique Veltman, irmão de Moyses, em depoimento à autora, em 28/3/2011.
} 
liberado com o seu nome pela Standard Propaganda, que produzia para o rádio e para a TV. Dois anos depois, conseguiria novamente um emprego, na Rádio Nacional, de onde sairia também por sua ligação com o comunismo.

A entrada na lista negra do rádio não era sua primeira complicação por motivos políticos. Logo na sua estreia nos palcos, com uma peça escrita quando tinha apenas 19 anos, aprendeu o que é cerceamento de liberdade. "Pé de Cabra", sobre um ladrão filósofo que falava em hipocrisia e distribuição de renda ${ }^{78}$, só pôde ser montada por Procópio Ferreira, em julho de 1942, após ter dez páginas cortadas pelo Estado Novo, que a considerou marxista. Dias, que jurava nunca haver lido Marx, resolveu ler.

Dois anos depois, 1944, iria se filiar ao Partido Comunista Brasileiro. ${ }^{79}$ Ele e o PCB tinham praticamente a mesma idade. Sob o reflexo da Revolução Russa de 1917, o Partido fora criado em um congresso em Niterói, em março de 1922, com a intenção principal de promover a revolução do proletariado, substituindo o capitalismo pelo socialis mo ${ }^{80}$. Sete meses depois, em 19 de outubro, nascia o dramaturgo, que passaria grande parte de sua vida seduzido por essa proposta, intercalando diferentes graus de ligação com o Partido. Como escreveu Igor Sacramento em seu doutorado sobre a obra de Dias Gomes, o autor "possibilitou no seu envolvimento com o PCB um intenso jogo entre a presença e ausência de princípios comunistas, sendo ora convocados, ora recusados". E concluiu: "Nesse jogo, a sua vinculação ao comunismo foi complexa. Ela não é um dado garantido, mas parte de processos sociais específicos e de variadas mesclas com outras culturas políticas" $"$.

Independentemente da intensidade de sua ligação com os comunistas, Dias Gomes convocou, da primeira à última obra, um exército de personagens que denunciariam as mazelas sociais do País.

\footnotetext{
78 GOMES, Dias. Peças da Juventude. Rio de Janeiro: Bertrand Brasil, 1994, p. 39-138

${ }^{79}$ GOMES, Dias. Apenas um subversivo. Rio de Janeiro: Bertrand Brasil, 1998, p. 100-101

${ }^{80}$ História do PCB no site do Centro de Pesquisa e Documentação de História Contemporânea do Brasil, da Fundação Getúlio Vargas (http://cpdoc.fgv.br/producao/dossies/AEraVargas 1/anos20/QuestaoSocial/PartidoComunista; acesso em 22/6/2016).

${ }^{81}$ SACRAMENTO, Igor Pinto. Nos tempos de Dias Gomes - A Trajetória de um intelectual comunista nas tramas comunicacionais, doutorado na UFRJ, 2012, p. 37
} 


\subsection{Capítulo 2 \\ O diário inédito}

A filiação de Dias Gomes ao PCB se deu quando ele tinha 21 anos e fora trabalhar na recém-inaugurada rádio Panamericana, em São Paulo, em 1944, a convite de Oduvaldo Vianna, que estava organizando uma célula entre os radialistas. Foi durante um curto período de legalidade do Partido, que os comunistas aproveitaram para estreitar relações com a intelectualidade.

Pouco depois de o escritor ser contratado pela rádio, Oduvaldo a vendeu, por pressões políticas, para Paulo Machado de Carvalho ${ }^{82}$, e Dias teve de deixar a emissora. Para a sua despedida, veiculou a adaptação de sua peça "Pé de Cabra", com seu grande amigo e convicto comunista Mário Lago no papel principal, que havia sido de Procópio Ferreira no teatro. A saída da emissora foi narrada por Dias de forma heroica: ao detectar a presença de dois policia is no estúdio, teria feito um discurso inflamado no ar, denunciando aos ouvintes a presença dos “cães". Microfone desligado, disse ter apanhado dos agentes e fugido pela sacada da rádio, aos berros contra a ditadura de $\operatorname{Vargas}^{83}$.

Nessa ocasião, antes mesmo de uma influência mais direta que os ideais do Partido pudessem ter em suas obras, juntou-se aos novos companheiros na militância de rua e pichações de muro ${ }^{84}$. Enquanto acompanhava as reuniões partidárias, passou por outras estações de rádio de São Paulo, até voltar ao Rio, em 1950, onde manteria seus contatos comunistas paulistanos e agregaria os cariocas, em passagens por diferentes rádios. Trabalhou na Tamoio e na Nacional, até chegar à Rádio Clube e à fatídica demissão em 1953.

Nesse período, teve intenso engajamento com o Partido e chegou a realizar reuniões em sua casa, contra a vontade de Janete Clair, que questionava o sentido da ligação partidária, além de temer pela segurança da família. Em 1956, teve lugar na casa do casal um encontro no qual Agildo Barata, membro do Comitê Central, confirmaria as

\footnotetext{
${ }^{82}$ A rádio Panamericana foi uma sociedade entre Oduvaldo Viana, que entrou com o trabalho e a experiência, Júlio Cosi e Eugênio dos Santos Neves, que financiaram a estação; verbete Rádio Jovem Pan do CPDOC da FGV, disponível em http://www.fgv.br/cpdoc/acervo/dicionarios/verbete-tematico/radiojovem-pan (acesso em 13/5/2016).

${ }^{83}$ GOMES, Dias. Apenas um subversivo. Rio de Janeiro: Bertrand Brasil, 1998, p. 97-98

${ }^{84}$ Entrevista de Dias Gomes a Marcelo Ridenti, no Rio, 22/1/1996, em RIDENTI, Marcelo. Brasilidade Revolucionária. São Paulo: Editora Unesp,2010, p. 66.
} 
denúncias do Relatório Krushev. O documento, lido no $20^{\circ}$ Congresso do Partido Comunista da União Soviética, em fevereiro daquele ano, denunciava graves crimes praticados por Stalin. Atordoado e sem respostas ao final da reunião, Dias sentiu vontade de chorar, sem conseguir, quando Janete lhe perguntou: "Já pensou que pode ser uma grande tolice essa sua ideia fixa de mudar o mundo?”. Ele respondeu com outra questão: "Mas, sem essa tolice, que sentido pode ter a vida?" 85

A convivência partidária amplificaria sua verve crítica, que parecia nata. Aos 15 anos, em 1937, escrevera a primeira peça, "A Comédia dos Moralistas"86, na qual uma família ultraconservadora aproveita um baile de máscaras no Carnaval para se comportar de forma libertina. A ousada história foi criada quatro anos antes de "A Mulher sem Pecado", de 1941, primeira peça de Nelson Rodrigues, que, dez anos mais velho que Dias Gomes, faria sucesso bem antes dele, com "Vestido de Noiva", de 1943, consagrando-se pela crítica mordaz à burguesia - por essa proximidade de propostas e pelo distanciamento político, Dias e Nelson, que se tornariam dois dos maiores dramaturgos brasileiros do século, eram desafetos: na versão televisiva de "O BemAmado", na década de 1980, Dias batizaria um jegue, que vivia a ser humilhado, de Rodrigues, "homenagem" ao colega; já Nelson comentou certa vez, sobre a possibilidade de Dias ser considerado o melhor autor do Brasil, que ele não era "o melhor autor nem da casa dele", em referência a Janete Clair ${ }^{87}$.

"Pé de Cabra", estreia de Dias Gomes no palco, e suas obras seguintes, já profissionais, mas ainda chamadas de "peças da juventude", buscavam uma conciliação entre as exigências do teatro que se fazia no momento, da chanchada, conhecido também como "teatro de boulevard", e a perspectiva nacionalista, de crítica política e social. Eram os anos 1940, e, nas montagens, ainda sem a presença de um diretor, as "estrelas" conduziam o espetáculo no palco, atuando como bem entendiam, com as falas sopradas por um ponto (pessoa que ficava na coxia).

Mas as companhias teatrais, ainda que de forma prematura, já estavam em busca da "consolidação de um modelo nacional", que representasse a nação, seja pela veia da

\footnotetext{
${ }^{85}$ GOMES, Dias. Apenas um subversivo. Rio de Janeiro: Bertrand Brasil, 1998, p. 161-163

${ }^{86}$ A peça foi laureada no concurso do Serviço Nacional do Teatro, em 1939.

${ }^{87}$ A frase foi lembrada por Ruy Castro, autor de Anjo Pornográfico, biografia de Nelson Rodrigues, em troca de e-mails com a autora, em abril de 2014.
} 
comédia ou do teatro dito "sério"88. A ansiedade de Dias Gomes para superar o "boulevard" e acentuar seu idealismo nos textos, além de deixar definitivamente para trás o trabalho no rádio e na TV, seguiriam pela década 1950 e iriam se evidenciar nas confidências anotadas em um diário cujos registros se iniciam em 1959 e se encerram em 1962. É um período crucial, quando definiria os princípios de sua obra e se consagraria como dramaturgo.

Desde o início da carreira, buscava se afirmar nos palcos para não precisar mais do suporte financeiro que o rádio the proporcionava. Apesar disso, admitia que no rádio conseguia "dialogar com outras manifestações artísticas e temas não apenas com exacerbado sentimentalismo", considerando sua audiência popular, "mas também tratar de assuntos sociais colocados pelas obras realistas e modernistas" 89 . Mais que isso, reconhecia o rádio "como espelho do sentir de nossa gente" e valorizava, assim como o Partido Comunista, seu "poder de penetração em grandes camadas de ouvintes" 90 .

De todo modo, era um veículo em que tinha de fazer mais concessões artísticas do que no teatro. Esse sim era o caminho da arte, acreditava, e da arte engajada. E por arte engajada se entendia, naquele momento, uma arte política de esquerda, de temática nacional-popular e estética realista. Dias explicitou seu próprio conceito para isso em um artigo publicado em 1968, com o título "O engajamento é uma prática de liberdade"91. Para ele, "toda arte é política" e "toda escolha importa em tomar um partido". Quem se pretende colocar em uma posição neutra, defendeu o escritor, favorece, por omissão, "o mais forte, ajudando a manter o statu quo". Nesse sentido, o teatro era a única arte capaz de usar o ser humano como expressão, marcando um ato político-social.

\footnotetext{
${ }^{88}$ Ver MERCADO, Antonio. Prefácio. In: GOMES, Dias. Peças da Juventude. Rio de Janeiro: Bertrand Brasil, 1994, p. 18; e SACRAMENTO, Igor Pinto. Nos tempos de Dias Gomes - A Trajetória de um intelectual comunista nas tramas comunicacionais, doutorado na UFRJ, 2012, p. 60.

${ }^{89}$ SACRAMENTO, Igor Pinto. Nos tempos de Dias Gomes - A Trajetória de um intelectual comunista nas tramas comunicacionais, doutorado na UFRJ, 2012, p.107

${ }^{90}$ Trecho de palestra de Dias Gomes no $3^{\circ}$ Congresso de Jornalistas, reproduzida pelo Correio Paulistano de 4 de dezembro de 1949. In: SACRAMENTO, Igor Pinto. Nos tempos de Dias Gomes - A Trajetória de um intelectual comunista nas tramas comunicacionais, doutorado na UFRJ, 2012, p. 114.

${ }^{91}$ GOMES, Dias. O engajamento é uma prática de liberdade. In: Revista Civilização Brasileira, Rio de Janeiro, ed. Julho, 1968
} 
O rádio e a recém-chegada TV não tinham essa aura. Dificilmente seriam considerados arte. Na melhor das hipóteses, uma arte menor, e quase sempre taxada de alienada. Meios de comunicação de massa eram sinônimos de alienação ${ }^{92}$.

Dias achava que "corria perigo de emburrecer" caso se "deixasse absorver por uma atividade inteiramente voltada ao divertimento" 93 . Ao final da primeira década de existência da televisão no Brasil, parecia ter encontrado uma saída contra esse "perigo", conforme registrou na primeira página de seu diário pessoal. $\mathrm{O}$ documento, que seguia inédito até esta dissertação e ao qual tivemos acesso no acervo do escritor em posse de sua viúva, tem início no dia 10 de agosto de 1959. Ao longo das 78 páginas manuscritas pelo dramaturgo em um pequeno caderno brochura de capa dura, ele revelaria o processo de criação de "O Pagador de Promessas" e outros dramas, como fica claro logo na abertura do documento:

Faz três dias -7 de agosto-completava eu 17 anos de teatro. 17 anos desperdiçados. Terei coragem de levar avante um exame de consciência?

Há cerca de dois meses, eu me sentia à beira da loucura. A ânsia de me realizar e a frustração que carregava comigo haviam se transformado em verdadeiras obsessões. Era uma ideia fixa que me perseguia de minuto a minuto. Agora estou melhor. Não sei a que atribuir. Se ao tratamento médico que estou fazendo, se à peça que estou escrevendo, “O Pagador de Promessas". Estou menos descontente comigo mesmo. ${ }^{94}$

A peça marcaria a mudança para uma nova fase de sua carreira, em que conquistaria reconhecimento nacional e internacional. O argumento central é inspirado em uma lembrança da infância do autor. Em 1935, quando Dias tinha 13 anos, sua mãe prometeu ao Senhor do Bonfim assistir a missas em todas as igrejas da Bahia (a lenda dizia serem mais de 365, uma para cada dia do ano, mas eram 92) se o filho mais velho, que se formara em medicina, conseguisse ser aprovado no Exército ${ }^{95}$.

\footnotetext{
92 A palavra "alienação" teria forte presença no vocabulário das disputas ideológicas do Brasil militar. O termo foi empregado por Hegel para indicar "o alhear-se a consciência de si mesma", quando a pessoa "se coisifica". Posteriormente, foi adotado por Marx para descrever a situação do operário no regime capitalista. Para ele, a propriedade privada produz a alienação do operário tanto porque cinde a relação des te com o produto do seu trabalho, quanto porque o trab alho permanece exterior ao operário, não pertence à sua personalidade. Para esses conceitos, ver ABBAGNANO, Nicola (2007). Dicionário de Filos ofia. São Paulo: Martins Fontes,p. 26.

93 GOMES, Dias. Apenas um subversivo. Rio de Janeiro: Bertrand Brasil, 1998, p. 93-94

${ }^{94}$ Diário de Dias Gomes, 10/8/1959, p. 1

95 GOMES, Dias. Apenas um subversivo. Rio de Janeiro: Bertrand Brasil, 1998, p. 7
} 
No diário, Dias demonstrava ter dimensão do que estava criando e previa o sucesso, conforme registro de 2 de setembro, quando falou sobre a formulação de Zé do Burro, o protagonista, que vive o drama de tentar entrar com uma cruz em uma igreja para agradecer pela cura do seu burro, mas é impedido porque a promessa para o salvamento do animal havia sido feita em um terreiro do candomblé:

Desde sexta-feira passada que estou doente, gripado. Durante esses dias, pude adiantar um pouco o "Zé do Burro". Estou agora bastante entusiasmado com a peça, pois vários problemas vão encontrando solução. Creio que esta peça terá importância decisiva em minha vida. Nela, eu começo a reencontrar-me. Um reencontro após 15 anos. ${ }^{96}$

Sua primeira grande obra, marco da cultura brasileira, ficaria pronta em 13 de outubro de 1959. E assim o feito foi registrado, no dia 31 do mesmo mês:

No dia 13 deste mês, terminei "O Pagador de Promessas". Como eu supunha, é um reencontro. Dei a peça a Edison Carneiro ${ }^{97}$ para ler e logo no dia seguinte ele me telefonou, entusiasmado. Fiz uma leitura para um grupo, do qual participavam Pascoal Longo e Silva Ferreira -pessoas que entendem de teatro-e as opiniões foram unanimemente entusiastas. Ontem, Pascoal me telefonou. Havia falado a Fernanda Montenegro sobre a peça e a elogiara tanto que ela me pedia "pelo amor de Deus" que fosse enviar-lhe uma cópia para ler. Entreguei outra cópia ao Teatro de Arena (para o qual não serve a peça) apenas para saber a opinião de um grupo jovem e honesto. Eles vão organizar um debate sobre a peça. Estou pensando também em ir à Bahia no princípio de dezembro, não só para assistirà Festa de Sta. Bárbara como para propor à Escola de Teatro da Universidade da Bahia encená-la. São projetos. O fato é que a peça desperta entusiasmo em quem a lê e eu tenho a impressão de ter escrito algo de valor. E o mais importante é que reencontrei um caminho..$^{98}$

\footnotetext{
${ }^{96}$ Diário de Dias Gomes, 2/9/1959, p. 4

${ }^{97}$ Nascido em Salvador, Edison Carneiro (1912-1972), que Dias chama em sua autobiografia de "fraterno amigo", foi etnólogo, folclorista e historiador, um dos mais destacados pesquisadores da cultura popular e membro do Partido Comunista (http://cnfcp.gov.br/interna.php?ID Materia=162, site do Centro Nacional de Folclore e Cultura Popular; acesso em 22/6/2016)

${ }^{98}$ Diário de Dias Gomes, 13/10/1959, p. 5
} 
Zé do Burro, homem simples e puro, é impedido por um padre de cumprir a promessa pelo salvamento de seu burro. O religioso representa a intolerância. Não só da própria Igreja, mas das instituições em geral, do poder constituído.

Diante da boa aceitação da peça, o dramaturgo ganhava forças para dizer "não" às solicitações da TV. Em 8 de novembro de 1959, anotou no diário: "Preciso me realizar como autor. Parece que reencontrei o meu caminho. Devo agora ter forças para não me deixar que afastem dele novamente. Recebi um convite de Aimeé ${ }^{99}$ para escrever uns programas de televisão para ela. Não vou aceitar. Chega de mediocrizar meu nome"100.

Em dezembro, após optar pela montagem da peça pelo TBC (Teatro Brasileiro de Comédia), de São Paulo -uma vez que o Teatro dos Sete (Gianni Ratto e Fernanda Montenegro), do Rio, só poderia montá-la dali a um ano e meio- ${ }^{101}$, visitou Salvador, sua cidade natal e cenário de "O Pagador de Promessas", para "tomar um banho de inspiração"102. Lá, assistiu a duas cerimônias do candomblé e à festa de Nossa Senhora da Conceição da Praia e concluiu: “Compreendo cada vez mais que só poderei realizarme como autor identificando-me e traduzindo os problemas do meu povo. Zé do Burro é um caminho que preciso seguir".

Depois da viagem a Salvador, esteve em São Paulo no dia 19 de dezembro, para uma reunião com Franco Zampari, em sua casa, um palacete no Jardim América. Fundador e diretor do TBC, o italiano radicado no Brasil contou a Dias que estava preocupado com o destino do grupo após a sua morte ${ }^{103}$. Para garantir a sobrevivência da companhia e dar a ela um norte, achava importante criar um teatro "genuinamente nacional". E "O Pagador de Promessas", afirmou ao autor, seria a primeira montagem dessa "nova fase". Para a direção, sugeriu o nome de Flávio Rangel ${ }^{104}$.

A preocupação de Zampari era reflexo do novo momento que o teatro brasileiro experimentava, aproximando-se cada vez mais do engajamento artístico que Ridenti

\footnotetext{
99 Aimée era Haidée Salles Lemos (1922-1980), atriz contemporânea e conterrânea de Dias. Trabalhou com Joracy Camargo no teatro de comédia e dirigiu sua própria companhia. Nos anos 50, atuava na televisão, no "Grande Teatro Tupi" (http://www.museudatv.com.br/biografias/Aimee.htm, site da Pró-TV, Associação dos Pioneiros, Profissionais e Incentivadores da Televisão Brasileira; acesso em 22/6/2016). ${ }^{100}$ Diário de Dias Gomes, 8/11/1959, p. 8-9

${ }^{101}$ Diário de Dias Gomes, 26/11/1959, p. 14

102 Diário de Dias Gomes, 12/12/1959, p 16

${ }^{103}$ Nascido em 1898, Franco Zampari imigrou ao Brasil em 1922 e em São Paulo fundou o TBC. Morreu em 1966 (http://enciclopedia.itaucultural.org.br/pessoa349649/franco-zampari; acesso em 22/6/2016) 104 Diário de Dias Gomes, 22/12/1959, p. 17-19
} 
chama de brasilidade revolucionária. Entre o final dos anos 50 e a década de 1970, teria lugar um sentimento romântico e revolucionário nas mais diversas áreas da arte -da literatura comunista de Jorge Amado, ao Cinema Novo de Glauber Rocha e à música tropicalista de Chico Buarque e Caetano Veloso, para citar alguns nomes expoentesque, apesar de trajetórias nem sempre simultâneas e com características diferentes, eram todos movimentos ligados aos ideais de esquerda.

Fundado em 1953, o Teatro Arena havia encenado durante todo o ano de 1958, com enorme sucesso de bilheteria, a peça "Eles não Usam Black Tie", pioneira ao levar aos palcos as questões de operários de uma fábrica, com um cenário de greves e piquetes $^{105}$. Foi escrita por de Gianfrancesco Guarnieri, ex-dirigente da União da Juventude Comunista em São Paulo.

Dois meses antes da conversa de Zampari com Dias Gomes, Guarnieri publicara na revista "Brasiliense" o artigo "O teatro como expressão da realidade nacional", em que propunha o fortalecimento da dramaturgia nacional e elogiava a "lei dos dois por um -obrigando a apresentação de um texto nacional após a montagem de dois textos estrangeiros- [que] veio estimular os autores brasileiros e obrigar as empresas a procurar furiosamente textos nacionais" ${ }^{106}$. O Arena -e mais tarde o CPC e o Opinião-, como analisou Ridenti, "expressava a busca por um lugar no campo realizada por jovens artistas, quase todos de esquerda e mesmo comunistas". E o caminho que Zampari procurava com “O Pagador de Promessas" era uma resposta às críticas enfrentadas pelo Teatro Brasileiro de Comédia. Os novos grupos teatrais ansiavam por uma "ruptura crítica com o TBC, que dava o tom de qualidade teatral nos anos 1950, mas era acusado por adversários de ser distanciado do povo e dos problemas nacionais, concentrando-se na montagem estrangeira" 107 .

Aos se acertar com esse que pretendia ser o "novo TBC", Dias Gomes pressentia o triunfo que se aproximava, mas isso não significava o fim de suas incertezas. E, em pleno Natal, dividia seus lamentos com o diário:

Preciso escrever outra peça. Sinto que, se "Zé do Burro" for um sucesso, eu precisarei ter uma peça pronta para aproveitar o caminho

\footnotetext{
105 MORAES, Dênis de. Vianinha: o cúmplice da paixão. Rio de Janeiro: Nórdica, 1991, p. 12 106 Trecho do artigo de Guarnieri citado em RIDENTI, Marcelo. Brasilidade revolucionária. São Paulo: Editora Unesp, 2010, p. 73.

107 RIDENTI, Marcelo (2010). Brasilidade revolucionária. São Paulo: Editora Unesp,p. 73-74
} 
reaberto. No entanto, para surpresa minha, vejo que estou ainda um tanto desnorteado. Não há dúvida de que "Zé do Burro" é um rumo. Por que então esse desnorteamento? Certas coordenadas estão já estabelecidas definitivamente:

a) meu teatro deve pôr em equação os problemas do meu povo;

b) numa forma nacional;

A verdade é que me encontro indeciso entre vários temas.

Compreendo que, depois de "Zé do Burro", minha responsabilidade cresceu. Preciso escreveralgo melhor. O problema da imigração nordestina, do choque e da desagregação das famílias nordestinas chegadas ao Rio me tenta. Sinto tipos, ambientes, clima -falta-me entretanto uma história que seja um achado, como Zé do Burro. ${ }^{108}$

Ainda na véspera da virada de 1959 para 1960, já chegaria ao tal "achado". Foi quando começou a escrever "A Invasão". Para ele, o novo trabalho guardava "certa unidade" com "Zé do Burro" mas soava como "um passo adiante". "Vou abordar problemas sociais mais profundos e fazer enfim um teatro brasileiro, em forma e conteúdo." ${ }^{109}$ Era uma ânsia absolutamente conectada com as intenções do PCB. A empreitada de artistas e intelectuais do Partido era, conforme aponta Ridenti, "popularizar a arte e a cultura brasileira, registrando a vida do povo, aproximando-se do que se supunha fossem seus interesses, comprometendo-se com a educação, buscando, ao mesmo tempo, valorizar suas raízes e romper com o subdesenvolvimento" 110 .

"A Invasão" fala de um grupo de favelados do Rio que, desalojado por uma enchente, ocupa o esqueleto de um prédio em construção e passa a enfrentar a ameaça do despejo em meio às promessas de um deputado demagogo e à polícia violenta e corrupta. Quando terminou o primeiro ato, o autor o considerou superior a "O Pagador de Promessas". "Pelo menos é algo socialmente mais vingado"111, anotou em 24 de janeiro. "Espero que essas duas peças definam as bases e as características do meu teatro." 112

${ }^{108}$ Diário de Dias Gomes, 25/12/1959, p. 20-21

${ }^{109}$ Diário de Dias Gomes, 31/12/1959, p. 22

${ }^{110}$ RIDENTI, Marcelo (2010). Brasilidade revolucionária. São Paulo: Editora Unesp,p. 74

${ }^{111}$ A palavra "vingado" foi o que a autora decifrou do que está escrito, porque a letra tem pouca clareza, a partir da comparação com outros trechos do diário; ela tem lógica com o teor da peça, e Dias Gomes usa a palavra "vingado" na última cena, para ilustrar a sensação dos personagens diante de um vilão assassinado e da notícia de que conseguiram evitar a ordem de despejo do prédio invadido com a ajuda de Rafael, um comunista.

112 Diário de Dias Gomes, 24/1/1960, p. 24 
Com a montagem de "O Pagador de Promessas" acertada e a criação de "A Invasão" fluindo bem, voltou a comemorar, em 7 de fevereiro, sua reaproximação com o teatro e o afastamento do rádio. "Sinto que começo a reconquistar o tempo perdido durante 15 anos de rádio. Parece que o teatro volta a tomar conhecimento de minha existência." 113

Concluiu "A Invasão" no final desse mesmo mês e se voltou às dúvidas sobre um personagem chamado Rafael ${ }^{114}$, que não aparece em cena, mas é diversas vezes citado nos diálogos. Apesar de não ser dito literalmente, fica claro ser um membro do Partido Comunista. Rafael está em contato com um dos invasores e, através dele, incentiva o grupo a resistir na ocupação, a realizar manifestações e um abaixo-assinado a ser enviado para a Justiça. Surge sempre na fala do favelado Lula, que se considera "um cara com pouco estudo", enquanto o Rafael "leu uma porção de coisas, sabe falar". As ideias do comunista são vistas com desconfiança por outros moradores, que deixam escapar críticas como as do personagem Bené: "Pra ele é muito fácil dizer que a gente deve fazer isso ou aquilo, ele não mora aqui..."

Dias temia que o público pudesse supor que "a peça o repudia integralmente". O autor, ainda que tenha declarado nunca ter submetido suas obras ao Partido ${ }^{115}$, revelou, em anotação feita em 24 de março de 1960, que o personagem Rafael havia sido motivo de divergência entre companheiros:

Este personagem "Rafael” não está sendo bem entendido por alguns companheiros do Partido. Seu sectarismo (pretendo demonstrar que embora haja no Partido comunistas sectárias, estes comunistas são pessoas bemintencionadas e eficientes, apesarde tudo, apesar de estarem erradas em seus métodos) Seu sectarismo, acham esses companheiros, o torna antipático e leva a plateia a concluir que todos os comunistas são as sim. Não estou de acordo. E pretendo manter o personagem. ${ }^{116}$

\footnotetext{
113 Diário de Dias Gomes, 7/2/1960, p. 25

${ }^{114}$ Diário de Dias Gomes, 29/2/1960, p. 26

115 Em entrevista a Marcelo Ridenti, no Rio, em 22/1/1996, Dias Gomes afirmou: "Eu sempre fui um rebelde com relação a isso, a submeter ao Partido aquilo que eu escrevia, as minhas peças de teatro, os meus livros, nunca submeti nenhum à apreciação do partido. A íntegra da conversa foi gentilmente cedida pelo autor para esta pesquisa.

116 Diário de Dias Gomes, 24/3/1960, p. 29-30
} 
Nesse mesmo registro, contou ter lido a peça a um companheiro de Partido que trabalhou por 12 anos em favelas. "O intuito era o de verificar a autenticidade dos meus personagens e das situações. O companheiro vibrou com a peça e nenhum reparo fez."

Essa passagem do diário é um indício da forma como o autor lidava com as orientações do Partido em relação às suas obras -como apontou o trecho anterior, ele também mostrou "O Pagador de Promessas" a Edison Carneiro, que era do PCB, ainda que não explicitasse se the apresentou o texto na condição de membro do Partido (em sua autobiografia, ao mencionar o episódio, chama Carneiro de "grande folclorista e fraterno amigo"). Dias declarou ser uma "falácia" que "no Comitê Central se discutiam e aprovavam ou reprovavam" a produção cultural de seus integrantes. "Nunca tive uma peça ou romance analisado ou discutido no comitê cultural ou em qualquer organismo partidário", escreveu.

Os apontamentos de Dias Gomes levam a crer que a peça tenha sido lida no PCB de maneira informal, por alguns membros que o dramaturgo escolheu. Mostram que a opinião entre os pecebistas não era unânime. Não dá a impressão, ainda que ele diga que ele fale de uma reprovação por alguns "companheiros", de uma interferência tão direta em seu processo de criação -tanto que o dramaturgo, a despeito das críticas a Rafael por alguns comunistas, manteve o personagem.

Há depoimentos que ilustram outro tipo de relação, no sentido contrário, com diversos casos de censura pelo Partido. Bráulio Pedroso, por exemplo, contou que "um dos romances de Rossine Camargo Guarnieri117 foi proibido pela cúpula partidária". "O Partido proibiu. Disse que era uma história reacionária, com um argumento dos mais cretinos. Foi um baque tão grande que Rossine ficou inibido de escrever."118 Diversos casos de vetos rígidos, em um clima de grande cerceamento e de hegemonia da doutrina partidária, foram relatados por Dênis de Moraes em "O Imaginário Vigiado". O escritor e historiador Paulo Cavalcanti contou que o dirigente Diógenes Arruda "matou e ressuscitou personagens de Jorge Amado, impediu que romances de Alina Paim fossem levados à URSS para tradução, ridicularizou poetas e novelistas do $\mathrm{PCB}$, tentou influir

\footnotetext{
117 Poeta e romancista comunista, irmão do compositor Mozart Camargo Guarnieri.

118 Depoimento de Bráulio Pedroso em SALEM, Helena. Nelson Pereira dos Santos: o sonho possível do cinema brasileiro. Rio de Janeiro: Nova Fronteira, 1987, apud MORAES, Dênis de. O imaginário vigiado - A imprensa comunis ta e o realis mo socialista no Brasil (1947-53). Rio de Janeiro: José Olympio Editora, 1994, p. 159; e RIDENTI, Marcelo. Brasilidade revolucionária. São Paulo: Editora Unesp, 2010, p. 80
} 
para manter inéditos manuscritos de Graciliano Ramos"119. Sobre a diferença entre esse tratamento coercitivo e o mais tolerante apontado por Dias Gomes, Ridenti pondera: a censura no Partido não era algo organizado como a do Estado e, além disso, "os dirigentes comunistas sentiam-se mais à vontade para cobrar coerência e obediência dos intelectuais dependentes do PCB, notadamente os que empregava"120.

A política e a arte perderam espaço para um drama familiar nos registros do diário de Dias Gomes, em 23 de maio: havia nascido seu filho Alfredo, prematuro e também com incompatibilidade sanguínea com a mãe. Dessa vez, dez anos após a morte do primeiro filho recém-nascido, em razão do mesmo problema, a medicina pôde salvar o bebê, mas a passagem é digna de roteiro de novela, e vale reproduzir um trecho:

Um exame de sangue do meu filho Alfredo revelou forte incompatibilidade sanguínea (...), fazendo-se necessária uma troca total de seu sangue (...), às 22 horas deveria ser iniciada. Durante 2 horas, entretanto, tentaram os médicos encontrar as veias necessárias (...) Desistiram, por fim (...) Chamou-se então um especialista em cirurgia infantil que deveria tentar localizar a veia na virilha. Veio o Dr. Paes, que, depois de uma hora, recusando-se a realizar a intervenção, alegando deficiência do aparelho da maternidade e aconselhando a remoção para o Hospital do Servidor do Estado (...) Estávamos à meia-noite de uma noite feia e chuvosa. Era uma temeridade transportara criança com aquele tempo. Mas disso dependia a sua vida. Entretanto, o médico do Hospital dos Servidores que deveria operá-lo, consultado por telefone, esquivou-se sob alegação de que deveria realizar outra intervenção pela manhã. Indicou um especialista em veias (...)

Telefonaram para o especialista e este se prontificou a rumar imediatamente para o Hospital (...) pois ele próprio possuía toda a aparelhagem necessária. Toda... exceto uma pequena peça. Parecia que o destino brincava de “suspense". Fui então de carro à casa do Dr. Beckstein, que possuía a tal peça. Trouxemo-la (...) Experimenta-se a peça. Nada, não se adapta.Bem, já eram 4 horas da madrugada, a operação precisava sertentada a qualquer

${ }^{119}$ MORAES, Dênis de. O imaginário vigiado - A imprensa comunista e o realismo socialis ta no Brasil (1947-53). Rio de Janeiro: José Olympio Editora, 1994, p. 159

${ }^{120}$ RIDENTI, Marcelo. Brasilidade revolucionária. São Paulo: Editora Unesp, 2010, p. 81 
preço. E tentou-se. Felizmente, com pleno êxito. Às 9 horas da manhã, estava concluída a transfusão. Meu filho estava salvo. ${ }^{121}$

Passado o susto e com o filho saudável, voltou-se no diário ao momento glorioso da carreira e, em julho, escreveu a respeito da estreia de "O Pagador de Promessas", no TBC, no dia 29:

Foi um sucesso extraordinário. Tudo aquilo que eu sonhava que acontecesse -mas que no fundo temia que não passasse de um sonhoaconteceu. Antes mesmo de cair o pano, a plateia levantou-se e aplaudiu de pé, gritou delirantemente. Fui arrastado ao palco e recebi uma verdadeira consagração.

Finalmente reencontro o caminho e começo a realizar-me. Isto serviu, principalmente, para me dar a certeza de que estou no caminho certo

Já recebi três propostas para filmagens e todo mundo quer "A Invasão".

Sinto-me como um homem que viveu duas vidas. A primeira encerrou-se na véspera da estreia do "Pagador de Promessas". Estou nascendo de novo. ${ }^{122}$

Em dezembro, já havia assinado contrato para a filmagem de "O Pagador" e, no primeiro dia de 1961, fazia um balanço do que acabava de se passar:

No início deste novo ano (acho que será decisivo para mim), fazendo um balanço do ano que passou, chego a um resultado muito animador. A verdade é que minha vida mudou de rumo em 60 . Eu me reencontrei. 61 será um ano de solidificar tudo o que conquisteiem 60 (na escola dos melhores do ano da Associação Paulista de Críticos Teatrais, "O Pagador" foi considerado, por unanimidade, o melhor espetáculo do ano, eu, o melhor autor, Flávio, o melhor diretor, Natália Timbert e Leo Vilar, os melhores atores, e Cyro del Nero, revelação de cenografia). ${ }^{123}$

Logo no dia 14 daquele mês de janeiro seria tempo de pensar na peça seguinte, "A Revolução dos Beatos", ainda chamada de "O Boi Santo". Ele queria tratar da

\footnotetext{
${ }^{121}$ Diário de Dias Gomes, 23/5/1960, p. 33-36

122 Diário de Dias Gomes, 31/7/1960, p. 37-38

123 Diário de Dias Gomes, 1/1/1961, p. 46
} 
"ignorância, da crendice em que vive imerso o sertanejo nordestino, por culpado cálculo de políticas venais que disso se servem para explorá-los". Sua intenção, conforme confidenciou ao diário, era que da peça pudesse "emergir um grito de revolta contra o crime que é perpetuado contra essa gente miserável, cujo desespero leva à procura do milagre. O milagre, venha ele de onde vier, como única salvação.” E concluiu: "O caminho não é combater a crendice como soldados o fazem; é educar essa gente"124.

Poucos dias depois, começou o texto da nova peça, e em 28 de janeiro deixou ainda mais claro os seus objetivos: "Demonstrar o interesse criminoso dos políticos e do clero em manter a ignorância do sertão nordestino, a exploração dessa ignorância".

A história se passa em Juazeiro, no Ceará, e aborda a exploração política do fanatismo religioso. Na primeira cena, uma tela instalada no palco traz informações sobre a cidade: "População: 20.000 habitantes; Milagres: 1.302; Escolas: 2; Crianças sem Escolas: 94\%”. A abertura do texto não deixa dúvidas do passo que o autor pretendia dar ${ }^{125}$ :

Esta é uma tentativa de teatro popular. Tentativa para encontrar uma forma brasileira para esse tipo de teatro, no qual o Povo se sinta representado, pesquisado, discutido e exaltado, em forma e conteúdo. Parece-me desnecessário dizer que esse teatro, além de popular, é também político -não poderia deixar de sê-lo. Se escrevemos para o Povo, uma pergunta se impõe: a favor ou contra? Pois não é possível ficar neutro com relação a ele. Como Povo, entendemos mass a oprimida. Se the apontamos caminhos para livrar-se da opressão, se o armamos contra o opressor, estamos a seu favor; se apenas o distraímos -e por consequência o distraímos da luta- estamos contra ele. Não há neutralidade possível.

Nesse primeiro semestre, dividiu-se entre a finalização de "A Revolução dos Beatos", as premiações de "O Pagador de Promessas" e de "A Invasão", além das negociações para a montagem das peças. Era um período frutífero, mas ele seguia tendo necessidade, por razões financeiras, de produzir para a televisão: fez os teleteatros " $\mathrm{O}$ Testa de Ferro" e "Vendem-se Terrenos no Céu"126. E os prêmios do teatro, ele recebia

\footnotetext{
124 Diário de Dias Gomes, 14/1/1961, p. 47-48

125 GOMES, Dias. A Revolução dos Beatos. In: Idem. A Invasão e A Revolução dos Beatos. Coleção Vera Cruz, vol. 40. Rio de Janeiro: Civilização Brasileira, 1962, p. 145

126 Diário de Dias Gomes, 14/5/1961, p. 50 e 24/6/1961, p. 62
} 
sempre de forma incômoda, procurando ironizar o louro e a si mesmo. Foi assim quando "A Invasão" ganhou o prêmio Cláudio de Souza, da Academia Brasileira de Letras, em junho. Primeiro, ele se disse surpreso com a conquista. Achava que "o sentido nitidamente socialista da peça haveria de desclassificá-la". "Estão de parabéns os acadêmicos", escreveu, para em seguida zombar de uma discussão interna que se travara, segundo os jornais, entre os imortais. O relator da comissão julgadora, Viriato Correia, havia submetido à comissão julgadora "a conveniência ou não de ser premiada uma peça com tantos (!) palavrões", registrou Dias no diário. "Um dos energúmenos propôs então que fosse sugerida ao autor a supressão dos palavrões. Mas outros energúmenos se opuseram (...) Após tremenda batalha, os palavrões saíram vencedores. Nem tudo está perdido nesta terra!"127 Também foi com sarcasmo que recebeu a quantia de Cr\$ 55 mil pelo prêmio. Na cerimônia, relatou ao diário, teve de ouvir "discursos chatérrimos". Por isso, considerou que "o preço foi apenas razoável"128.

Se no $1^{\circ}$ de janeiro havia se mostrado animado com 1961, que prometia ser o "ano da solidificação" do que plantara em 1960, o passar dos meses trouxeram outro sentido a esse período. Em 14 de julho, traçou algumas linhas que se propunham a tentar organizar esse sentimento ambíguo em relação ao seu sucesso:

Preciso escreveroutra peça. Faz quase quatro mes es que terminei “A Revolução dos Beatos”. Depois disso, escrevi apenas duas peças de televisão. Estou produzindo pouco. Não sei porquê. A verdade é que estou um tanto atordoado. Minha carreira teatral está sendo travada em algum pon to. Ganho prêmios, recebo homenagens, mas minhas peças não são encenadas. Não quero prêmios, não quero homenagens, quero ser representado. Fora disso, a vida de dramaturgo não tem sentido. Amanhã oferece-me um almoço em razão dos meus "êxitos" no teatro. Paulo Francis diz que eu sou o autor da moda. E tudo is so me parece tão injustificado. ${ }^{129}$

No dia seguinte, seria homenageado na Academia com um almoço que reuniu nomes como Jorge Amado, James Amado, Oduvaldo Vianna (pai e filho), Alex Viany e o mítico comunista Luís Carlos Prestes ${ }^{130}$. Ver-se consagrado diante de intelectuais

\footnotetext{
127 Diário de Dias Gomes, 17/6/1961, p. 60-61

128 Diário de Dias Gomes, 29/6/1961, p. 63

129 Diário de Dias Gomes, 14/7/1961, p. 64

130 Diário de Dias Gomes, 15/7/1961, p. 65
} 
imortais, grandes amigos e do maior líder do PCB parecia um sonho do consumo, para ser irônica como o autor. Mas ele não enxergou dessa forma, bem ao contrário:

Sinto-me como um traidor de mim mesmo. Três violentações de personalidade me ocorreram esta semana: recebi um prêmio da Academia, fui homenageado com um almoço e tive que comparecer (por dever e gratidão) à posse de Jorge Amado. Começo a ser dominado por esse sentimento de culpa inexplicável, como se estivesse me acomodando, me aburguezando, me academizando vergonhosamente. Chega, chega, chega. ${ }^{131}$

Seu drama de consciência, para além de suas questões pessoais, poderia ter como pano de fundo a paradoxal relação entre o Partido Comunista e os artistas e intelectuais, vistos como "burgueses". Em entrevista a Ridenti, Dias Gomes relatou o incômodo:

Quando eu ingressei no partido nos anos 40 ainda havia uma política de muita suspeição, vamos dizer assim. Não só com relação aos intelectuais como em relação à classe média de um modo geral. Nós éramos olhados as sim como aliados muito suspeitos, possíveis traidores, tanto que procurávamos até nos vestir de uma maneira mais simples possível, nas reuniões alguns até iam com camisas um pouco esfarrapadas para se parecer mais aos proletários. ${ }^{132}$

Era, de lado a lado, "uma relação contraditória de concorrência, admiração, inveja, medo, respeito e desrespeito, reconhecimento e ressentimento. Partiam de dirigentes comunistas - que se consideravam operários- as acusações contra os 'desvios pequeno-burgueses" da intelectualidade"133. É bem verdade que a convivência havia se tornado menos conflituosa a partir de meados dos anos 1950, com o auge do comunismo mundial e a alta adesão da intelectualidade ao PCB. Mas Osvaldo Peralva, escritor e jornalista que participou da cúpula pecebista, relatou que, com o clima de abertura que se impôs após as denúncias do Relatório Krushev, em 1956, reascendeu “o desprezo e o ódio nutridos pelos dirigentes máximos do Partido em relação aos intelectuais" -ainda que a direção tivesse interesse político na participação desses nomes. O ímpeto da intelectualidade comunista em debater as necessidades de

\footnotetext{
${ }^{131}$ Diário de Dias Gomes, 18/7/1961, p. 66

132 RIDENTI, Marcelo. Brasilidade revolucionária. São Paulo: Editora Unesp, 2010, p. 82

133 Ibidem.
} 
mudanças fez com que passassem a ser chamados internamente de "piroquetes", "pequeno-burgueses em desespero", "elementos vacilantes ante a pressão ideológica do inimigo de classe", "funcionários do Dops" e "vendidos ao imperialismo ianque". Já a visão idealizada em torno do proletariado, herdada da Revolução Soviética, o apresentava como a "classe eleita", "portadora de todas as virtudes morais e cívicas", "possuidor de qualidades superiores inatas".

Diógenes Arruda, dirigente do Partido e citado por Peralva como um dos que se relacionavam mal com a intelectualidade ${ }^{134}$, decidiu agrupá-los em um comitê de finanças, dirigido por Agildo Barata. O objetivo então não seria pensar os rumos do País, mas arrecadar dinheiro, o que incomodava Dias Gomes. O fato de todos serem intelectuais e artistas, facilitava as reuniões, travestidas de encontros para falar sobre arte. Também para disfarçar, costumavam levar as mulheres e os filhos, que ficavam em outro cômodo da casa, enquanto se discutiam as ações políticas. Dias certa vez foi designado a conseguir dinheiro e pediu para o ator e empresário de teatro Jayme Costa, com quem negociava montar uma de suas peças. Simpatizante, ele colaborou. Muitos também acabavam dando dinheiro por medo. A ordem da direção era reforçar a simpatia dos simpatizantes e o medo dos medrosos ${ }^{135}$. Em 1950, a arrecadação feita entre os convidados do casamento do dramaturgo com Janete Clair para ajudar os noivos foi entregue ao Partido. Dias chegou a pedir para ficar com uma parte, mas o secretário encarregado de buscar com ele o envelope não permitiu: "Companheiro, isso é dinheiro para a revolução"136.

Dias comentou o incômodo com Ridenti:

Havia muita manipulação, por exemplo, na utilização que o Partido fazia dos intelectuais, dos artistas, para obter fundos econômicos. Isso era uma coisa que me chocava bastante, a determinação de conseguir dinheiros, cotas etc. e tal, para manter o Partido. Como a minha participação era emocional e romântica, is so me chocava, até porque eu achava que não estava no Partido pra conseguir dinheiro, mas para lutar por alguma coisa. E

\footnotetext{
134 PERALVA, Osvaldo. O retrato. São Paulo: Três Estrela, 2015, p. 356

135 Informações sobre o comitê financeiro são de entrevis ta de Henrique Veltman à autora.

136 GOMES, Dias. Apenas um subversivo. Rio de Janeiro: Bertrand Brasil, 1998, p. 116-117
} 
vinha daí um pouco de subestimação da intelectualidade. O Partido é aquela visão de que o intelectuais não é muito confiável. ${ }^{137}$

O fato é que sensação de distância em relação ao "povo" persistia, ao menos para Dias Gomes -ainda que, em certa medida, tenha se tornado característico da política cultural do PCB um certo elitismo em que "os intelectuais comunistas (a 'vanguarda') deveriam orientar as massas nos caminhos da revolução"138. O "aburguesamento" soava como um dilema para ele em 1961, ano em que sua glória estava só começando, com o sucesso em âmbito nacional. Mas a internacionalização de seu nome estava sendo gestada. Em agosto, contou ter estado em São Paulo para rever o roteiro cinematográfico de "O Pagador de Promessas". O filme era algo que, até aquele momento, parecia desprezar. Nem o nome do diretor, Anselmo Duarte, havia mencionado no diário, e essa era a segunda vez que tocava no assunto, para comentar sobre o script: "Parece-me medíocre, embora não traia o espírito da peça". Diversos questionamentos o atormentavam, e ele, mais do que entender o caminho de sua arte, ansiava descobrir o papel de sua geração.

Eis o registro de 2 de agosto:

Preciso escreveroutra peça. Gostaria de traduzir algo do espírito de minha geração - geração que tem exata noção de seu papel de pioneira, de desbravadora de caminhos para gerações futuras. E se revolta contra as gerações passadas, que nada lhe legaram. E consciência de que todo es forço despendido servirá apenas para adubara terra onde germinará a semente, que só as gerações futuras edificarão realmente alguma coisa, pois já encontrarão o solo fertilizado -essa consciência de um papel menor, de uma impossibilidade de realização completa, torna a minha geração amargada, revoltada. Embora ela se diga o contrário, a verdade é que não lhe agrada plantar para ser colhido pelos que virão depois. Minha geração gostaria de ter um papel, de protagonizar alguma coisa. E sabe que is so não acontecerá. Muito embora tenha consciência de estar contribuindo para que as gerações futuras -talvez a próxima geração- possa realizar-se. Mas is so não basta. Gostaria de criar um personagem(que teria muito de Paulo Francis, um

\footnotetext{
${ }^{137}$ RIDENTI, Marcelo. Em busca do povo brasileiro - artistas da revolução, do CPC à era da TV. Rio de Janeiro: Record, 2000, p. 136 138 SACRAMENTO, Igor. Por uma teledramaturgia engajada - a experiência de dramaturgos comunistas com a televisão dos anos de 1970. In: NAPOLITANO, Marcos; CZAJKA, Rodrigo; MOTTA, Rodrigo Patto Sá. Comunistas Brasileiros - Cultura política e produção cultural. Belo Horizonte: Editora UFMG, 2013, p. 113
} 
pouco de Flávio Rangel) que exprimiria tudo isso numa agressividade devastadora (atacando grandes medalhões, como o Jorge Amad o ${ }^{139}$, como o Schimit ${ }^{140}$ ), mostrando o ridículo dos que se julgam realizados, dos que se supõem projetados no futuro. Este é o País do tempo-dirá. ${ }^{141}$

Diante desse turbilhão, faria apenas mais duas anotações nesse ano de 1961. Em 13 de outubro, relatou a estreia de "O Pagador de Promessas" pelo Teatro de Amadores de Pernambuco ${ }^{142}$. A última nota, de 2 de novembro, era uma passagem aparentemente sem importância, em que reclamava de uma montagem em Recife na qual haviam mudado o final de "O Pagador de Promessas", com a porta da igreja abrindo-se milagrosamente para Zé do Burro ser colocado para dentro, e não sendo forçada pelo povo revoltado. Mas as linhas finais tornam essa página do diário histórica:

Comecei ontem a escrevernova peça. Ainda não tenho o título, mas a história me parece muito boa. É baseada em fato real, ocorrido em Guarapari, cidadezinha do litoral capixaba. Vou fazê-la passar-se em Itaparica, entretanto. ${ }^{143}$

\footnotetext{
139 Aqui a redação é ambígua, pode significar que Jorge Amado e Schmidt são "grandes medalhões" ou que Dias Gomes quer atacar "grandes medalhões" como fazem Amado e Schmidt. A segunda hipótese é mais provável, visto que Amado e Dias eram amigos pessoais e membros do PCB. Troca de correspondência entre eles obtida para esta pesquisa mostra intensa amizade entre os dois, que se tornariam compadres em 1987, quando Jorge Amado e Zélia Gattai batizam Mayra, filha de Dias Gomes com Bernadeth Lyzio. Jorge Amado foi o grande incentivador da candidatura de Dias Gomes à Academia Brasileira de Letras. O descompasso que pode ser visto entre eles, contudo, se daria exatamente nessa época do registro do diário, na forma de se relacionar com o Partido Comunista. Jorge Amado demonstrava, conforme relata Ridenti, concordância irrestrita com as diretrizes do partido, da política de Jdanov (político soviético correligionário de Stalin que liderava um controle estético-ideológico à produção cultural comunista), e submetia suas obras à censura partidária. Dias sempre se mostrou incomodado com essa subordinação e se dizia um comunista "rebelde" por recusarorientações do Partido. ${ }^{140}$ Ele provavelmente se refere a Augusto Frederico Schmidt, poeta, ensaísta e empresário, que em 1930 fundou uma editora com o seu sobrenome e publicou livros de Jorge Amado, Rachel de Queiroz e Graciliano Ramos, entre outros. Amigo de Juscelino Kubitschek, teve influência em seu governo (19561961), sendo embaixador, conselheiro financeiro e tendo criado o famoso slogan "50 anos em 5" (MIRANDA, Stefano. Há 50 anos, morria Augus to Frederico Schimidt, Jornal do Brasil, 8/2/2015, disponível em http://www.jb.com.br/pais/noticias/2015/02/08/ha-50-anos-morria-augusto-fredericoschmidt/; acesso em 22/6/2016).

${ }^{141}$ Diário de Dias Gomes, 2/8/1961, p. 68-69

142 Diário de Dias Gomes, 13/10/1961, p. 70

143 Diário de Dias Gomes, 2/11/1961, p. 71
} 
A história real a que o autor se refere the havia sido narrada por um amigo, o capixaba Nestor de Holanda, cronista do jornal "Última Hora"144. É do início do século, 1906, quando foi construído o primeiro cemitério de Guarapari, batizado São João Batista. Muito dinheiro e pompa na obra, acontece que o local não podia ser inaugurado porque a população "gozava de boa saúde" e ninguém morria na cidade. As críticas dos moradores ao gasto "inútil" só cresciam a cada dia sem defunto, e isso duraria dez anos. Em 1916, o cemitério finalmente seria inaugurado, mas com um morto emprestado de uma cidade vizinha, Benevente, hoje Anchieta. A cerimônia de inauguração foi uma cena pronta para a obra que iria inspirar. Diante de várias autoridades, o vereador Belarmino Santana fez um inflamado discurso em que exaltou Guarapari como "o País da saúde e das maravilhas", lugar onde "nunca ninguém morre nem se entristece". Lembrou que foi preciso "emprestar um defunto" de outro lugar, e "um defunto da pior espécie, pois não passa de um mulambo". Com o braço direito esticado em direção ao mar, comemorou que Guarapari "tem o oceano marital”. E com o esquerdo apontando a floresta, prosseguiu: "E do outro lado tem o oceano matagal". Foi então vaiado pela plateia, de onde ouviu-se um grito: "Cala a boca, negro burro".

A resposta do político soa como embrião do protagonista que Dias Gomes criaria: "Sou burro sim, porém artista como uma locomotiva que gera no azul do firmamento. Sou negro sim, mas porém a cor da epiderme não inflói nem contribói, como diria o grande general Marechal Hermes (...) Essa aparte que acabamos de ouvir é a prova das razões por que esta merda de cidade não vai adiante e eu me recuso a continuar falando para ignorantes e analfabetos". E desceu do palanque dando uma banana para público ${ }^{145}$.

É uma perfeita cena de Odorico Paraguaçu, o prefeito de Sucupira, protagonista de "O Bem-Amado". A peça ficaria pronta no último dia de 1961 e seria a antecessora de "O Berço do Herói”. Em um pequeno intervalo (1961-1963), Dias Gomes criaria as

\footnotetext{
${ }^{144}$ Para a informação de que a história lhe havia sido narrada por Nestor de Holanda, GOMES, Dias. Apenas um subversivo. Rio de Janeiro: Bertrand Brasil, 1998, p. 187; em 1985, em entrevista à "Playboy", Dias afirmaria que ficara sabendo pormeio do cantor Jorge Goulart: COURI, Norma. Playboy entrevista Dias Gomes. Playboy, 12;1985, p. 61; para a versão televisiva, iria se inspirar em Carlos Lacerda para a criação do prefeito Odorico Paraguaçu; em entrevista sobre a série, em 1981, mencionaria o projeto de Lacerda, quando governadordo Rio, de transformar o Parque Lage em cemitério também como fonte para a criação da história: ALMEIDA, Miguel de. Uma piada transformada em seriado de sucesso. Folha de S.Paulo, 27/6/1981, p. 52.

145 Site de Turismo de Guarapari (https://turismoguarapari.wordpress.com/category/cultura/; acesso em $22 / 6 / 2016)$
} 
duas obras que dariam origem aos seus maiores sucessos televisivos, "O Bem-Amado" e "Roque Santeiro".

No primeiro dia de 1962, lembrou-se da expectativa confidenciada um ano antes ao diário: 'Há um ano eu escrevia: 'Este será um ano decisivo para mim'. Terá sido. Parece-me que decisivo mesmo será 62". Contou ter terminado de escrever a nova peça e confessou não estar muito satisfeito com o texto, ainda com "vários defeitos"146.

Em meio à sua fase mais frutífera, não se sentia bem. "O Pagador" e "A Invasão" seguiam boas carreiras, mas detalhes o aborreciam "profundamente", como o fato de a história de Zé do Burro, apesar de prestes a estrear no cinema, não estar nos palcos no Rio. Em fevereiro, lamentou passar por dias de "depressão terrível", "num estado de nervos insuportável". Sua instabilidade reverberava no casamento: "Nem sei como Janete me suporta. A verdade é que ela não entende como posso dar tanta importância ao teatro em minha vida; e às vezes se revolta. Com razão"147.

Haveria ainda as duas derradeiras anotações, que circunscrevem o exato tempo de virada, quando deixaria de ser um dramaturgo respeitado no País para se tornar respeitado internacionalmente. Em 31 de março, narrou o lançamento, na noite anterior, do filme "O Pagador de Promessas", e aproveitou o episódio para comparar as particularidades da arte teatral às da cinematográfica:

Foi uma grande noite a de ontem. O filme extraído de "O Pagador de Promessas" foi exibido em sessão especial para convidados. Repetiu-se então a da estreia da peça, em S. Paulo, com a plateia aplaudindo de pé e gritando "bravos". Foi um delírio. O filme (que foi escolhido, por unanimidade, por um júri composto de membros do Itamarati, do Geicine ${ }^{148}$ e críticos, para representar o Brasil no Festival de Cannes) está sendo considerado o maior filme já feito no Brasil e a cena final do enterro de Zé do Burro uma cena antológica, digna dos maiores cinemas do mundo. É realmente um belo filme, que me comoveu bastante, não só pela sua beleza plástica, como pela

\footnotetext{
146 Diário de Dias Gomes, 1/1/1962, p. 72

147 Diário de Dias Gomes, 6/2/1962, p. 73-74

148 Criado por decreto em fevereiro de 1961, o Geicine (Grupo Executivo da Indústria Cinematográfica) tinha como atribuição definir a política nacional para a produção de cinema.
} 
fidelidade ao meu pensamento. Entretanto, ele me convence também de que o palco é o veículo ideal ao drama; o cinema é uma arte plástica, essencialmente. Na tela as ideias ganham em plasticidade, mas perdem em densidade dramática e aprofundamento humano e filosófico. O que eu quero dizer, enfim, é dito no palco muito mais claramente, muito embora, no cinema, cresça em alegoria. Por que será? Parece-me que isso se deve não a um defeito do filme, mas à própria condição do cinema. É porque no teatro o meio básico de exposição é o homem enquanto que no cinema é a figura [grifos do autor]. O drama é inerente ao homem, ninguém melhor do que ele, ao vivo, para expô-lo. ${ }^{149}$

Não foi só a cabeça do autor que se dividiu com o filme. Napolitano aponta que a versão cinematográfica da peça, "o maior triunfo do cinema brasileiro", nunca seria aceita como obra do Cinema Novo e de sua "estética da fome". "Mais próximo de uma estética neorrealista e dentro dos padrões clássicos de narrativa cinematográfica linear, não buscava o "choque", como os filmes de Glauber Rocha, por exemplo, "mas fazia com que o público, independentemente da classe social ou da formação cultural, sofresse junto com aquele homem simples". Esse dilema entre o "choque" proposto pelo Cinema Novo e a "identificação" com que "O Pagador de Promessas" trabalha "pode ser considerado a síntese dos impasses que marcavam a arte engajada brasileira, na busca de caminhos para se comunicar com as classes populares e educar as elites para um novo tempo de mudanças que parecia promissor". A análise soa válida para toda a obra de Dias Gomes, que "dialogava com uma variedade de matrizes estético-culturais distintas: a tragédia, a comédia de costumes, o teatro de revista, o realismo burguês, o romantismo e os elementos do teatro épico brechtiano e do realismo crítico lukacsiano", em uma prática de "aliança entre o comunismo e o liberal"150.

O embate que Dias Gomes colocou entre o teatro e o cinema pode ser visto como embrião de outro que o perseguiria por toda a vida: os palcos versus a tela da televisão. Ele, basicamente, concluiria que, se o teatro ganhava em qualidade artística, perdia em alcance da plateia, que era um objetivo de sua arte revolucionária. Mas, naquele início dos anos 1960, em meio aos louros e à grande plateia do cinema, o dramaturgo

\footnotetext{
149 Diário de Dias Gomes, 31/3/1962, p. 75-76

150 SACRAMENTO, Igor. Por uma teledramaturgia engajada - a experiência de dramaturgos comunistas com a televisão dos anos de 1970. In: NAPOLITANO, Marcos; CZAJKA, Rodrigo; MOTTA, Rodrigo Patto Sá. Comunistas Brasileiros - Cultura política e produção cultural. Belo Horizonte: Editora UFMG, 2013, p. 110
} 
preocupava-se mesmo com sua carreira nos palcos. Na mesma data em que relatou o êxito da estreia cinematográfica, falou do desassossego em relação a uma montagem pelo TNC, o Teatro Nacional de Comédia. Estava descontente porque Edmundo Moniz, o diretor marxista do SNT (Serviço Nacional de Teatro) nos governos JK e João Goulart, estaria impondo a participação de uma "atriz medíocre, mas sua grande paixão". Dias confessou ter ponderado o fato de que o elenco masculino era bom e ter aceitado a imposição de Moniz por não estar em uma situação financeira "das melhores". E fecha esse quadro com a seguinte conclusão: "A concessão é uma regra e uma imposição do regime capitalista" 151.

O diário termina em 31 de maio de 1962. Não é conhecida a razão pela qual decidiu interrompê-lo, ainda que se saiba que isso aconteceu quando seu nome ganhou projeção inédita, a partir da qual passaria a ser muito requisitado, de eventos e trabalhos a entrevistas para a imprensa. Essa era pelo menos a segunda vez que guardava em um caderno suas confidências. No acervo em poder de sua viúva, há uma pequena caderneta com relatos feitos ainda na adolescência, sobre as primeiras tentativas de escrever para o teatro.

Aos 36 anos, começara seu segundo e provavelmente último diário, noticiando o início da criação de "O Pagador de Promessas". Dois anos, nove meses, 21 dias e 49 anotações depois, narrou o coroamento da versão cinematográfica da peça no Festival de Cannes. Como bom dramaturgo, deu ao diário um arco dramático completo, com começo, meio e fim. E, no último capítulo, colocou em cena sua ironia cortante:

No dia 23 do corrente, "O Pagador de Promessas” ganhou a Palma de Ouro no Festival de Cannes. Só agora, 9 dias depois, consigo sentar-me para registrar o feito neste diário. É que, de hora para outra, vi-me transformar no nome mais requisitado do Brasil. Entrevistas, programas de televisão, homenagens, tudo veio como uma torrente. Passei a ser herói nacional. Parece-me que em tudo isso há um grande equívoco. ${ }^{152}$

151 Diário de Dias Gomes, 31/3/1962, p. 77

152 Diário de Dias Gomes, 31/5/1962, p. 78 


\subsection{Capítulo 3 \\ O falso mito, mais que pornográfico}

"O Pagador de Promessas" fez com que o cinema brasileiro conquistasse repercussão internacional pela primeira vez, ao vencer, em 1962, o Festival de Cannes, a mais conceituada premiação cinematográfica do mundo. A Palma de Ouro foi concedida ao filme baseado no texto de Dias Gomes em um ano especialmente rico para a cultura brasileira. Napolitano lembra que 1962 foi quando se deu "a confirmação da Bossa Nova como modelo da nossa moderna canção engajada e a formalização do Cinema Novo como um grupo". Além disso, duas iniciativas de 1961 se fortaleceram na ocasião: o Centro Popular de Cultura (CPC), da União Nacional dos Estudantes, e as campanhas de alfabetização dos adultos com o método de Paulo Freire, em que cada palavra ensinada trazia uma conscientização, no dizer do educador, da realidade social.

O Brasil sagrara-se bicampeão na Copa do Mundo de 1962, e as rádios tocavam "Garota de Ipanema", de Tom Jobim e Vinicius de Moraes. "Era mesmo uma procura de identidade cultural para o País; todo mundo gostava de ser brasileiro porque a Bossa Nova, o Cinema Novo, o mundo inteiro conheceu", afirmou o roteirista e dramaturgo Izaías Almada, militante político, a Ridenti, que cita a Palma de Ouro a "O Pagador de Promessas", para completar: "O teatro estava sempre cheio, aquilo dava uma alegria muito grande."

Era um tempo de euforia e de utopia, de "empolgação da esquerda com o Brasil"'153, com acaloradas discussões sobre a conscientização da sociedade pela via da educação e da cultura. De um lado, havia a corrente que defendia que o artista deveria deixar sua condição de "burguês" e abandonar modelos eruditos ou de vanguarda a fim de criar obras para um despertar direto do povo -como assinala Napolitano, a ideia era a de que "antes de atingir o povo, o artista deveria se converter aos novos valores e procedimentos, nem que para isso sacrificasse o seu deleito estético e a sua vontade de expressão pessoal'"154. De outro, os que argumentavam que a agenda ideológica não

\footnotetext{
153 O termo "empolgação da esquerda" e o depoimento de Izaías Almada estão em RIDENTI, Marcelo. Em busca do povo brasileiro - artistas da revolução, do CPC à era da TV. Rio de Janeiro: Record, 2000, p. $37-38$

154 NAPOLITANO, Marcos. 1964 - His tória do regime militar brasileiro. São Paulo: Contexto, 2014, p. 21
} 
deveria atropelar a estética, a arte não poderia buscar uma popularização forçada, o que chamavam de "populismo cultural".

De uma forma ou de outra, o domínio era de uma arte de esquerda. Esse caldo cultural foi aglutinado pelo governo de João Goulart, que assumira em setembro de 1961 após a renúncia de Jânio Quadros, de quem era vice, e depois de enfrentar uma tentativa de golpe militar para evitar sua posse ${ }^{155}$. Se a temperatura estava alta no Brasil, externamente a política pegava fogo. No final daquele ano de 1962, os Estados Unidos descobriram mísseis militares instalados pelo governo soviético em Cuba. Os artefatos foram retirados após um acordo em que os americanos se comprometeram a não invadir a ilha comunista. "Nesses dias a guerra nuclear esteve por um fio de cabelo"156.

$\mathrm{O}$ anticomunismo da Guerra Fria atingiria em cheio a política nacional em um governo cuja bandeira eram as "reformas de base", que incluíam reforma agrária, bancária, eleitoral, tributária e a regulamentação da remessa de lucros das multinacionais para suas matrizes ${ }^{157}$, deixando a elite financeira apavorada. Em janeiro de 1963, um plebiscito decidiu pela retomada do presidencialismo, em detrimento a um parlamentarismo imposto por militares após a renúncia de Jânio, a fim de anular o poder de João Goulart. Com o presidente de volta ao comando, o País incendiou.

Em fevereiro, empresários do Rio e de São Paulo, preocupados com os rumos econômicos do Brasil -em que viam influência comunista no aumento da intervenção estatal, entre outras iniciativas do governo-, fundaram oficialmente o Ipes (Instituto de Pesquisas e Estudos Sociais), com grupos que já vinham se reunindo desde o ano anterior, e que ganharia adesão de outros estados, representando com mais força os interesses da classe empresarial ${ }^{158}$. Nesse mesmo período, outra associação da mesma linha estava no auge de suas atividades: o Ibad (Instituto Brasileiro de Ação Democrática), criado em 1959, ao final do governo de Juscelino Kubitschek, com a contribuição do empresariado nacional e estrangeiro, principalmente norte-americano. Tendo como objetivo combater o comunismo e influenciar os caminhos políticos do

\footnotetext{
155 Ibidem, p. 20

156 GASPARI, Elio. A ditadura envergonhada. São Paulo: Companhia das Letras, 2002, p. 381

157 NAPOLITANO, Marcos. 1964 - His tória do regime militar brasileiro. São Paulo: Contexto, 2014, p. 17

${ }^{158}$ His tória do Ipes no site do Centro de Pesquis a e Documentação de His tória Contemporânea do Brasil, da Fundação Getúlio Vargas

(http://cpdoc.fgv.br/producao/dossies/Jango/artigos/NaPresidenciaRepublica/O_Instituto_de_Pesquisa_e Estudos Sociais; aces so em 22/6/2016)
} 
País, lançou a Ação Democrática Popular (Adep) com o propósito de canalizar recursos financeiros a candidatos contrários a Goulart nas eleições para governadores em 11 Estados e para o Congresso Nacional. Paralelamente, produzia programas de rádio, de televisão e reportagens de jornais anticomunistas ${ }^{159}$. Em outubro, em resposta à ofensiva de direita, Jango tentou impor o estado de sítio, mas nem a esquerda the apoiou. $\mathrm{Na}$ sombra do conflito ideológico, surgiu o CCC, Comando de Caça aos Comunistas, organização paramilitar de extrema direita de apoio à intervenção militar.

Carlos Lacerda se dedicava a uma exaustiva campanha contra Jango. Eleito governador da Guanabara em 1960, havia vendido em 1961 a "Tribuna da Imprensa", que, entre tantas cruzadas políticas de Lacerda, em 1953 causara a demissão de Dias Gomes ao denunciar sua participação na viagem a Moscou. O jornalista e agora político seguia com seus discursos virulentos em outros periódicos, nas rádios e na televisão, que ultrapassava a marca de um milhão de aparelhos no País.

Esse era o panorama quando ficou pronta a peça “O Berço do Herói”. A nova obra vinha na sequência da que tratava dos mandos e desmandos do prefeito corrupto Odorico Paraguaçu ("O Bem-Amado”, 1962), da exploração política do fanatismo religioso ("A Revolução dos Beatos", 1961), do problema da falta de moradia ("A Invasão", 1960) e da denúncia à intolerância (“O Pagador de Promessas”, 1959). Era chegada a vez de dar holofotes ao mito dos falsos heróis.

A história de "O Berço do Herói” foi inspirada em um caso verídico registrado por Euclides da Cunha em "Os Sertões"160. Aconteceu na Guerra de Canudos (7 de novembro de 1896 a 5 de outubro de 1897), quando se deu a disputa de um povoado do interior da Bahia, liderado por Antônio Conselheiro, contra o Exército da recéminstalada República. No conflito, um cabo foi dado como morto e transformado em herói. Mas apareceu três dias depois, vivinho da silva. O fato ocorreu na quarta expedição militar à pequena cidade de Canudos, e após a morte, essa real, do capitão Salomão da Rocha, comandante da $4^{\mathrm{a}}$ Bateria do $2^{\circ}$ Regimento de Artilharia a Cavalo, da ordenança do coronel Antônio Moreira César.

A lenda que "abalou comovedoramente a alma popular", conforme registrou Cunha, foi assim descrita pelo autor em "Os Sertões":

\footnotetext{
${ }^{159}$ Idem para o Ibad (http://cpdoc.fgv.br/producao/dossies/Jango/artigos/NaPresidenciaRepublica/O_Instituto_Brasileiro de Acao Democratica; acesso em 22/6/2016).

160 GOMES, Dias. Apenas um subversivo. Rio de Janeiro: Bertrand Brasil, 1998, p. 222-223
} 
Um soldado humilde, trans figurado por um raro lance de coragem, marcara a peripécia culminante da peleja (...) Quando desbaratara-se a tropa, e o cadáver daquele ficara em abandono à margem do caminho, o lutador leal permanecera a seu lado, guardando a relíquia veneranda abandonada por um exército. De joelhos, junto ao corpo do comandante, batera-se até ao último cartucho, tombando, afinal, sacrificando-se por um morto...

E a cena maravilhosa, fortemente colorida pela imaginação popular, fez-se quase uma compensação à enormidade do revés. Abriram-se subscrições patrióticas; planearam-se homenagens cívicas e solenes; e, num coro triunfal de artigos vibrantes e odes ferventes, o soldado obscuro transcendia à história quando - vítima da desgraça de não ter morrido-, trocando a imortalidade pela vida, apareceu com os últimos retardatários supérstites ${ }^{161}$, em Queimadas. ${ }^{162}$

O episódio do herói dado como morto, mas que não morrera, foi simbólico de algo maior que se passara na Guerra dos Canudos, o que Cunha chamou de "catástrofe":

Os trezentos e tantos mortos das informações oficiais ressurgiam.

Três dias depois do recontro, três dias apenas, já se achava em Queimadas, a duzentos quilômetros de Canudos, grande parte da expedição. Uma semana depois, verificava-se, ali, a existência de 74 oficiais. Duas semanas mais tarde, no dia 19 de março, lá estavam-salvos-1.081 combatentes. ${ }^{163}$

Em um estilo que guarda semelhança impressionante com o que marcaria a obra de Dias Gomes, Cunha finaliza a história da lenda com a seguinte ironia: "Vimos quantos entraram em ação. Não subtraiamos. Deixemos aí, registrados, estes algarismos inexoráveis". Mais do que se inspirar a história central de "O Berço do Herói”, essa passagem de "Os Sertões", de 1902, parece ter sido fonte para o espírito sarcástico que caracterizaria essa peça e a sua versão televisiva, batizada de "Roque Santeiro", além de tantas outras criações de Dias Gomes.

No prólogo de "O Berço do Herói”, o escritor orienta que se crie um ambiente que provoque o público, no bom sentido, desde o primeiro instante. O espetáculo deve

\footnotetext{
${ }^{161}$ Supérstite significa sobrevivente.

162 CUNHA, Euclides (1902). Os Sertões. São Paulo: Saraiva; edição de 2011, p. 302-303

163 Ibidem
} 
começar com o palco escuro e o barulho de um gongo elétrico. Pelo microfone, uma voz diz: "Notícia de falecimento de todos os heróis". A fala é seguida por nova batida do gongo, até que um jato de luz é jogado sobre um coro, que canta:

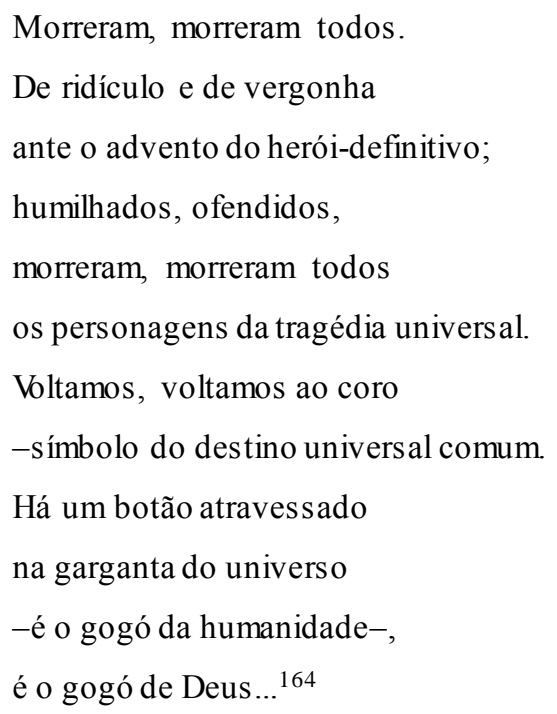

Ao final da canção, com o palco escuro, um ator surge na boca da cena, segurando uma lanterna, que aponta para os espectadores: “Atenção, atenção. Se há algum herói na plateia, queira subir ao palco por favor. Nenhum herói? Nenhum herói? Obrigado. Temos então de nos arranjar com o que nos resta".

Uma tela montada no palco mostra um filme com a lenda do Cabo Jorge. A fita contará o que se passou como verdade. Na sequência, que se desenrola na Segunda Guerra Mundial, enviados da Força Expedicionária Brasileira estão em uma trincheira na Itália, que é bombardeada por nazistas. Para evitar a morte dos companheiro, Cabo Jorge subitamente solta um grito de guerra e corre em direção aos inimigos, sendo metralhado. Encorajados pelo heroísmo, seus camaradas partem para o ataque. As botas dos soldados passam por cima do corpo ensanguentado de Jorge e seguem rumo à vitória, acompanhada pela música em tons wagnerianos.

Após o filme, os atores entram em cena no palco. Somente no quarto quadro, a plateia entenderá que a cena cinematográfica nunca havia acontecido, fora criada pela imaginação popular. A sequência do audiovisual seria uma representação do que todos gostariam que tivesse ocorrido, porque ela constrói um herói. E em torno desse mito

\footnotetext{
164 GOMES, Dias. O Berço do Herói, 4a ed. Rio de Janeiro: Bertrand Brasil, 1997, p. 17-18; todas as citações da peça foram retiradas dessa edição
} 
passa a girar a cidade do protagonista - rebatizada de Cabo Jorge-, a crença de seus habitantes, o comércio de santinhos e de lembrancinhas e, claro, a ganância dos políticos. Ninguém poderia imaginar, longe disso, que o cabo nunca havia saído da trincheira para salvar a Pátria. Ele fugira, desertara, e passara os últimos dez anos em bordéis europeus. Sua volta às origens ameaça a cidade, que "progredira" com o turismo em torno do mito -agora tinha até casa de raparigas! Políticos e comerciantes passarão a esconder Jorge. Farão de tudo para manter o vivo morto, mesmo que, para isso, tenham de matá-lo.

O povo, ao se deparar com indícios da farsa, mostra-se disposto a fugir da verdade para preservar o mito -e aí está uma grande riqueza da obra. Dias evita maniqueísmo na criação do povo, que não é colocado como uma massa uniforme completamente "boa", "perfeita", apesar da formação comunista do autor. No desenho de cada personagem, tenta fugir do simplismo, o que se tornaria um atributo de seu trabalho. Se Cabo Jorge é um anti-herói, o Major Chico Manga pode ser visto como antivilão, sendo assim descrito pelo autor no prólogo da peça:

\footnotetext{
O Major Chico Manga é o chefe político local. Negocista, demagogo, elegendo-se à custa da ignorância de uns e da venalidade de outros, convicto, entretanto, de ser credor da gratidão de todos pelas benfeitorias que tem conseguido para a cidade. E talvez o seja, até certo ponto [grifo nosso].É dessa classe de políticos -bem numerosa, aliás, entre nós-que acha que o relativo bem que fazem os absolve do todo o mal que espalham. E que se Deus fez o bem e o mal, foi para que coexistissem. O que se deve fazer é tirar o maior proveito possíveldo mal em favor do bem. Assim, se se permite a prostituição, o jogo, mas se se cobra uma boa taxa para a igreja ou a Prefeitura, está tudo justificado. Podia-se atribuir a ele aquela célebre frase de um parlamentar patrício: "Política se faz com a mão esquerda na consciência e a direita na merda". ${ }^{165}$
}

Ao fim da descrição, esclarece: “O título de 'Major' não lhe advém de posto militar, mas de seu prestígio e de suas posses". Representa, assim, algo comum nas cidades brasileiras, especialmente no Nordeste, regidas pelo coronelismo, inspiradoras de suas criações. Ao explicar que o major não era major, Dias antecipava problemas que a peça teria a partir da tomada do poder pelos militares no Brasil, mas para os quais a 
ressalva se mostraria ineficaz: uma dose de vacina insuficiente diante do significado da obra e do histórico de militância comunista do autor.

Entre a criação de “O Berço do Herói”, em 1963, e a tentativa de montá-la, em 1965, viria o golpe de 1964. Naquele momento, Dias Gomes era diretor da Rádio Nacional e desenvolvia intensa atividade política. Na madrugada de 31 de março para $1^{\circ}$ de abril, estava em casa, com febre, mas decidiu correr para a emissora, que mantinha no ar discursos contra a ocupação militar. O local estava repleto de militantes solidários a Jango, que faziam discursos ao microfone. Quando viu o historiador e general reformado Nelson Werneck Sodré, seu companheiro do PC e do Comando dos Trabalhadores Intelectuais, Dias the pediu que se sentasse à máquina para redigir $o$ primeiro boletim de guerra das forças antigolpe. Lido no ar, o texto era um "delírio ficcional" que dizia que o golpe seria esmagado.

A estação não tardou a ser tomada pelo Exército, e Dias e outros funcionários tiveram de fugir. Esconderam-se em um pequeno hotel durante a noite e, no dia seguinte, seguiram para um apartamento que abrigava esquerdistas, onde planejaram pedir asilo na embaixada da Argentina. No caminho, contudo, Dias desistiu de acompanhar o grupo, desceu do carro e se escondeu por alguns dias na casa do amigo Flávio Rangel, até ser levado para a fazenda dos pais de Paulo de Oliveira, aquele que lhe emprestara o nome para pseudônimos no episódio da lista negra em 1953. Lá, passou um mês, profundamente deprimido ${ }^{166}$. O Ato Institucional $\mathrm{n}^{\mathrm{o}} 1$, de 9 de abril, deu início a uma série de "investigações sumárias", seguidas de expurgos. Decreto de 23 de julho, listou 36 demitidos da Rádio Nacional, entre eles os pecebistas Nora Ney, Mário Lago, Oduvaldo Vianna e Dias Gomes ${ }^{167}$.

No início daquele 1964, o dramaturgo havia entregue os originais de "O Berço do Herói" à editora Civilização Brasileira, reduto de intelectuais comunistas. Com a tomada dos militares, Mário da Silva Brito, estudioso da literatura brasileira que atuava na editora, escondera "O Berço do Herói” em sua residência. Foi uma sorte, porque, nesse meio tempo, Dias teve sua casa invadida por integrantes do Exército, que procuravam "livros subversivos" e chegaram a revistar a bolsa de Janete Clair ${ }^{168}$.

\footnotetext{
166 Entrevista de Dias Gomes à revista "Playboy", edição de dezembro de 1985 167 SACRAMENTO, Igor Pinto. Nos tempos de Dias Gomes -A Trajetória de um intelectual comunista nas tramas comunicacionais, doutorado na UFRJ, 2012, p. 200 168 GOMES, Dias (1998). Apenas um subversivo. Rio de Janeiro: Bertrand Brasil, p. 212
} 
Só um ano depois, no começo de 1965, a peça seria publicada pela Civilização. O prefácio do livro era assinado por Paulo Francis, que experimentara a profissão de ator de teatro nos anos 1950 e iniciara o trabalho de crítico teatral no final da mesma década. Em 1963, quando “O Berço do Herói” foi escrita, Francis havia estreado uma coluna política na "Última Hora", mas, com o golpe, perdera o emprego posteriormente se aliaria à imprensa de resistência à ditadura, chegando a atuar em " $\mathrm{O}$ Pasquim"169, símbolo da imprensa de oposição aos militares. Ao escrever o prefácio da peça de Dias Gomes, logo no primeiro parágrafo, o crítico dá aos novos donos do poder tudo o que eles queriam. Ou melhor, não queriam: “'O Berço do Herói’ é uma comédia política, onde o mito do heroísmo vai pelos ares depois de examinado pelo autor à luz dos interesses da classe dominante em nosso País".

Francis ressalta uma evolução na obra do dramaturgo: "O propósito de subordinar caracterização psicológica ao efeito coletivo das forças em choque" ${ }^{170}$. Isso exige que o público observe cada personagem, do padre ao general, como pessoa e não apenas elemento da equação política, explica o autor do prefácio. A humanização não diminui o impacto das críticas. Ao contrário, as valoriza, pois aproxima a obra da vida real, onde todos têm suas próprias contradições e ambiguidades, além do exercício de um papel social.

O final do texto de Francis se encaixa perfeitamente no que os militares qualificavam como "provocação". O crítico chama o governo de Castello Branco de "parafascista". Diz que a peça é "naturalmente subversiva" e encerra lembrando frase do líder nazista alemão Goering "tantas vezes convertida em atos depois do $1^{\circ}$ de abril: 'Quando ouço falar em cultura, sinto vontade de sacar o revólver'. Esta é a Ordem do Dia do Brasil de hoje".

A oretha do livro não seria menos ousada. Era assinada por Ênio Silveira, membro do Partido Comunista e dono da editora. Quase simultaneamente à publicação de "O Berço do Herói”, Silveira lançaria a "Revista Civilização Brasileira", referência do pensamento de resistência à ditadura militar. Com esse currículo, seria o alvo predileto da repressão aos livros que se deu nos primeiros anos da ditadura, até 1968. Nesse período, a censura às obras literárias "foi marcada por uma atuação confusa e

\footnotetext{
${ }^{169}$ Site Memória Globo; memoriaglobo.globo.com ${ }^{170}$ FRANCIS, Paulo. Prefácio de 1964. In: GOMES, Dias. O Berço do Herói. $4^{\mathrm{a}}$ edição. Rio de Janeiro: Bertrand Brasil, 2005, p. 7-11
} 
multifacetada, pela ausência de critérios mesclando batidas policiais, apreensões, confisco e coerção física". Silveira "foi preso várias vezes, processado outras tantas e viu a Editora Civilização Brasileira ser invadida, e sua produção editorial, apreendida"171.

Esse ambiente não o desencorajou a abrir o texto sobre "O Berço do Herói”" afirmando que "a índole pacífica e civilista de nosso povo tem recebido com sorrisos irônicos toda e qualquer tentativa (...) de transformá-lo em adorador de pretensos heróis militares". Ele vai direto ao ponto: "Estamos vivendo, desgraçadamente, uma dessas fases de agressiva convivência com os militares (...) Os homens que se assenhorearam do poder pelo golpe de abril entendem que sua farda é uma espécie de toga sagrada". Os militares, ataca o editor, são daqueles que passam a "entender de tudo, de importação de alpiste às tendências da Bossa Nova...”. Apesar de tudo, otimista, escreve que eles não conseguiriam "representar o País por muito tempo".

“O Berço do Herói”, em sua opinião, dá uma "ilustração precisa, conquanto caricata, dessa incompatibilidade entre os dois ângulos de visão -militar e civil.” E encerra com uma análise pronta para figurar relatório de censor: "Dias Gomes tinha um alvo a atingir e o alcança plenamente. Os mitos brasileiros, espontâneos ou feitos a martelo, sempre acabam assim: explodem como bolhas de sabão e seus respingos atingem a muita gente"l172.

Se a peça em si já possui plenas credenciais para se complicar com o novo governo do País, prefácio e orelha terminam por cobri-la de pólvora. Com essa publicação da Civilização Brasileira, a prisão de Francis e de Silveira chegou a ser pedida ao Conselho de Segurança Nacional, o que não aconteceu naquela ocasião ${ }^{173}$ Silveira seria preso meses depois, em maio de 1965, por ter servido uma feijoada ao exgovernador pernambucano Miguel Arraes, no que ficou conhecido como IPM da Feijoada $^{174}$.

A publicação de uma crítica tão contundente foi possível porque, na fase anterior ao AI-5, o aparato repressor ideológico estava em fase de montagem, o que possibilitava

\footnotetext{
${ }^{171}$ REIMÃO, Sandra. Censura a livros no Brasil - breve panorama histórico. In: COSTA, Maria Cristina Castilho (Org.). A censura em debate. São Paulo: ECA/USP, 2014, p. 117

172 SILVEIRA, Ênio. Orelha escrita em 1965. In: GOMES, Dias. O Berço do Herói. 4a edição. Rio de Janeiro: Bertrand Brasil, 2005

173 Para o pedido de prisão, COURI, Norma. Playboy entrevista Dias Gomes. Playboy, 12/1985, p. 75

174 GASPARI, Elio. A ditadura envergonhada. São Paulo: Companhia das Letras, 2002, p. 231
} 
"a coexistência de práticas autoritárias com algumas liberdades individuais" $" 175$. Se, por um lado, o aparelho autoritário "deixava" publicar algo assim, por outro, logo providenciava uma forma de tornar um inferno a vida de qualquer pessoa que resolvesse expor ideias contrárias às do poder. Em 13 de junho de 1964, apenas 74 dias depois do golpe, havia sido criado o Serviço Nacional de Informações. Uma lei com dez parágrafos definiu a função oficial do novo órgão governamental: "Superintender e coordenar em todo território nacional as atividades de informação e contrainformação, em particular as que interessem à Segurança Nacional'. A estrutura cresceria ao longo dos anos, sendo até informalmente patrocinada pela iniciativa privada de apoio aos militares, mas a verba inicial já não era pequena: Cr\$200 milhões, enquanto o saláriomínimo da época era de Cr\$38 $3{ }^{176}$.

Assim, "O Berço do Herói”' foi "liberada” em formato de livro, mas Dias Gomes, Paulo Francis e Ênio Silveira ganharam, com isso, mais um motivo para serem fichados pelo SNI, o que seria a gênese dos Inquéritos Policiais Militares, os chamados IPMs. Tudo isso funcionava, em última instância, como censura, e da mais poderosa e perversa. Como explica Napolitano, "o controle e a perseguição à atividade intelectual escrita era feita, principalmente, via IPMs (Inquéritos Policiais Militares) e processos judiciais, implantando o chamado 'terror cultural', que transforma todos os intelectuais críticos em potenciais subversivos "inimigos da pátria"'177.

Nesse ambiente, seria preciso muito destemor para levar a peça aos palcos. E ele partiu do Grupo Decisão. Fundado em 1963 por Antonio Abujamra, usava como pilar o teatro brechtiano, em que cada gesto do ator ganha um significado, para sustentar textos essencialmente politicos. Dias sabia a carga que esse diretor daria ao seu texto. Posteriormente, em sua autobiografia, diria que certamente a encenação estaria impregnada das ideias da escola norte-americana Living Theatre, de teatro experimental político radical (fundada em 1947 por Julian Beck e Judith Malina, que seriam presos nos anos 1970 no Brasil, quando estavam envolvidos com o Teatro Oficina). Abujamra preparava uma montagem de “O Berço do Herói” para chocar.

\footnotetext{
175 STEPHANOU, Alexandre. Censura no regime militar e militarização das artes. Porto Alegre: Edipucrs, 2001, p. 13

176 BAFFA, Ayrton. Nos porões do SNI - O retrato do monstro de cabeça oca. Rio de Janeiro: Objetiva, 1989, p. 13

177 NAPOLITANO, Marcos. 1964 - His tória do regime militar brasileiro. São Paulo: Contexto, 2014, p. 100
} 
Para o elenco principal, chamou Milton Moraes, no papel de Cabo Jorge, Sebastião Vasconcelos, como Major Chico Manga, e Tereza Rachel, na pele da sedutora Viúva Antonieta. Um vendedor ambulante da história seria interpretado por Clóvis Bueno, persona non grata do poder, com forte atuação no movimento estudantil, no CPC e com todas as ligações de esquerda possíveis com a Bossa Nova e o Cinema Novo, chegando a integrar a Organização Revolucionária Marxista Política Operária, a Polop. Outro com um papel menor na peça mas não na política era Luiz Mendonça, ligado também ao CPC, além do Teatro Arena e o Opinião.

O cenário ficou sob a responsabilidade do arquiteto Anísio Medeiros, a quem Dias já havia confiado "O Pagador de Promessas" e "A Invasão". A direção musical, a cargo do jovem Edu Lobo, pernambucano de 21 anos que começava a se envolver com a Bossa Nova e com peças de teatro engajadas, especialmente em razão do contato com o amigo Carlos Lyra, que atuava no CPC, da UNE. Naquele primeiro semestre de 1965, Edu Lobo ganharia seu primeiro prêmio. Sua música "Arrastão", com letra de Vinicius de Moraes e interpretação de Elis Regina, venceu o $1^{\circ}$ Festival Nacional de Música Brasileira, realizado pela TV Excelsior no Guarujá (litoral de São Paulo). Na ocasião, o músico radicado no Rio nem pôde se juntar à festa de comemoração na casa de Vinicius, na capital carioca, porque estava em São Paulo preparando a estreia do musical "Zumbi, Rei dos Palmares", que seria rebatizada de "Arena Conta Zumbi"178. Dirigido por Gianfrancesco Guarnieri e Augusto Boal, iria se tornar um dos símbolos do teatro político de resistência à ditadura.

Para o grupo musical de “O Berço do Herói”, Edu chamou Osvaldo Sargentelli, que em 1964, por ordem da ditadura militar, deixara de apresentar na TV Tupi o programa "O Preto no Branco", em que entrevistava convidados "polêmicos", entre eles muitos comunistas. Além dele, estava o jovem de 20 anos Dori Caymmi, que no ano anterior havia codirigido a peça "Opinião" e no ano seguinte seria levado por Edu Lobo para o espetáculo "Arena Conta Zumbi"179.

Os ensaios de "O Berço do Herói”" eram acompanhados pelo diretor musical no Teatro Princesa Isabel, no Rio, ao lado de Abujamra e muitas vezes de Dias Gomes. A cada encontro, ganhava novas tintas. Nesse processo, Dias ia mudando o texto e Edu, a

\footnotetext{
178 MELlO, Zuza Homem de. A Era dos Festivais - Uma Parábola. São Paulo: Editora 34, 2003, p. 71 ${ }^{179}$ As informações sobre o grupo musical foram dadas pelo ator Clóvis Bueno, em entrevista à autora em 2/9/2011.
} 
música. O coro do início, decidiram, não só declamaria a poesia sobre a morte dos heróis, que já era forte, como o faria marchando, o que dirigia a crítica ainda mais diretamente aos militares. A cada nova alteração, os atores tinham de redecorar e reensaiar tudo, sempre em um caminho mais ferino.

A montagem contava veladamente com patrocínio de Newton Rique ${ }^{180}$, que, eleito prefeito de Campina Grande (PB) em 1963, fora deposto pelo golpe militar em junho de 1964 e passara a administrar o Banco Industrial de Campina Grande, de propriedade de sua família, e a colaborar com produções culturais com as quais simpatizava.

O texto foi encaminhado à Censura do Estado no início de junho de 1965, como era de praxe, 45 dias antes da data marcada para a estreia, 22 de julho. Até então, o poder censório ainda se encontrava descentralizado pelos estados, enquanto a estrutura federal para isso não ficava pronta -em 16 de novembro de 1964, uma lei havia atribuído ao Departamento Federal de Segurança Pública a função de censurar diversões públicas, mas, ainda sem ênfase ao teatro, deixava especialmente a cargo desse órgão a fiscalização de "filmes cinematográficos que transponham o âmbito dos Estados".

A censura ao teatro brasileiro, base para o que depois se daria em outras áreas artísticas, inclusive na televisão, havia sido institucionalizada no século anterior, com a criação do Conservatório Dramático Brasileiro (CBD). Responsável pelas peças apresentadas na corte de 1843 a 1864, tinha o objetivo de selecionar e exigir mudanças nas obras, zelando pela "moral e bons costumes". "Com a proclamação da República, em 1889, e a promulgação da Constituição de 1891, uma reestruturação das competências transferiu a responsabilidade pela censura para organismos policiais". A partir desse momento, ficaram mais evidentes as razões políticas das proibições.

Na era Getúlio Vargas, a Constituição de 1934 vetou mensagens de guerra, de violência e subversão da ordem política e social. Com o DIP, a partir de 1939, a repressão se centralizou e se ligou diretamente ao poder do presidente. Após a queda do Estado Novo, o Departamento Nacional de Informações (DNI) substituiu o DIP. José Linhares, que sucedeu Vargas, assinou o decreto 20.493, que regulamentava a censura, e criava o Serviço de Censura de Diversos Públicas (SCDP), que, entre outros setores, tratava de teatro, programas de rádio e letras músicas -depois iria incorporar a TV.

\footnotetext{
${ }^{180}$ As informações sobre os ensaios e sobre o patrocínio da peça foram dadas pelo ator Sebastião Vasconcelos, que interpretava o Major Chico Manga, em entrevista à autora, em 1\%/9/2011.
} 
A censura teatral seguiu nos anos democráticos que se deram entre a ditadura Vargas e a militar, priorizando as questões morais, mas com a mesma estrutura legislativa que previa cerceamento a tudo que pudesse ferir os "interesses nacionais" e depreciar as Forças Armadas. É importante a síntese de Miliandre Garcia de Souza:

\footnotetext{
A censura de diversões públicas não foi criada na ditadura militar para atender às demandas da época, mas redefinida por lideranças do governo conforme determinações políticas. Assim, a re-significação da censura e a centralização do serviço responderam às necessidades conjunturais dos governos militares de assumir o controle nacional da produção artística que trans gredisse preceito ético-moral ou que veiculasse mensagem políticoideológica. ${ }^{181}$
}

O teatro foi a área mais visada da censura na fase pré AI-5 da ditadura militar, "menos pelo seu alcance social e mais pela capacidade de mobilização dos setores intelectuais de oposição". Quando "O Berço do Herói” estava sendo montada, a repressão às peças se encontrava mais descentralizada e em fase de reformulação administrativa de sua estrutura (a partir de 1972, haveria uma maior centralização no governo federal e, em seguida, uma volta à descentralização).

O roteiro da peça de Dias Gomes foi aprovado pelos censores do governo Lacerda. Porém, para a liberação definitiva do espetáculo, os agentes públicos deveriam assistir a um ensaio geral, o que costumava acontecer na véspera da data da estreia. Essa falta de antecedência era uma tortura psicológica para a equipe da peça, que se preparava para entrar em cena sem saber se isso aconteceria. Funcionava também como censura econômica, assim como outros dispositivos censórios -a exemplo de um decreto-lei de 1940, do Estado Novo, que atribuía ao governo federal a fiscalização sobre a liberação de papel para os jornais. O fato de o parecer definitivo sobre as peças só sair mediante um ensaio geral realizado na véspera fazia com que o teatro se tornasse um investimento de alto risco, o que inibia patrocinadores.

A censura prévia a espetáculos aparecera pela primeira vez na legislação republicana brasileira em 9 de dezembro de 1920. O decreto 14.529, de Epitácio Pessoa, que também proibia corrida de touro, garraios (bezerros) e novilhos, além de brigas de

181 O trecho citado e os três parágrafos com informações sobre a censura ao teatro estão em SOUZA, Miliandre Garcia. "Ou vocês mudam ou acabam": aspectos políticos da censura teatral (1964-1985). Doutorado na UFRJ, 2008, p. 237. 
galos e canários, impunha regras detalhadas ao funcionamento de casas de espetáculo públicos, desde a necessidade de um vestiário privativo para as senhoras "conservado com o máximo asseio" até colocação de pelo menos três cabides fixos nos camarotes e frisas. Vetava a exibição de anúncios "ofensivos à moral e aos bons costumes ou que se refiram a moléstias ou incômodos secretos ou repugnantes" e proibia os artistas de acrescentar ou retirar partes do texto. Tinha até regras para o espectador, que, "salvo o direito de aplaudir ou reprovar", não poderia gritar ou fazer discursos sem prévia autorização da autoridade policial. E determinava que os textos deveriam ser entregues ao $2^{\circ}$ delegado auxiliar pelo menos 30 dias antes da estreia -nesse item da censura prévia, assegurava que a polícia não entraria "na apreciação do valor artístico da obra", mas trazia extensa lista de vetos previstos, da moral e bons costumes a ofensas à religião, instituições nacionais e até a Países estrangeiros ${ }^{182}$.

Quatro anos depois, em 10 de setembro de 1924, novo decreto determinava que as casas de diversão deveriam estar de portas abertas, de dia ou de noite, para "o chefe da polícia, delegados auxiliares, censores e autoridades do distrito". A lei falava de um "camarote da polícia" e de cadeiras nos teatros que deveriam conter, nas suas costas, uma placa com a palavra “CENSOR”. Com esses dois decretos, de 1920 e 1924, começava a se desenhar nitidamente a ligação entre censura e polícia.

Em 10 de dezembro de 1928, mais um decreto, de número 18.527, criava o dispositivo do ensaio geral para referendar ou não a avaliação feita previamente do texto da peça. Assinado por Washington Luis, regulamentava a organização de empresas de diversão pública, autorizando, por exemplo, mulheres casadas, com mais de 18 anos, a serem empresárias, desde que com autorização do marido. Nas regras sobre o contrato de trabalho entre empresários e artistas, definia que os funcionários não precisavam ser remunerados pelo ensaio geral à Censura, tarefa a que estavam "obrigados a prestar, nos termos dos regulamentos policiais vigentes" $" 183$.

O famigerado decreto 20.493, assinado em 24 de janeiro de 1946, criava 136 artigos para regulamentar a censura no País. Tão extenso, sobreviveu ao tempo, tendo sido o mais utilizado para justificar pareceres durante toda a ditadura militar e só sendo

\footnotetext{
182 Texto original do decreto disponível no site da Câmara dos Deputados (http://www2.camara.leg.br/leg in/fed/decret/1920-1929/decreto-14529-9-dezembro-1920-503076publicacaooriginal-1-pe.html; acesso em 22/6/2016).

183 Texto original disponível no site do Palácio do Planalto (https://www.planalto.gov.br/ccivil_03/decreto/1910-1929/D18527.htm; acesso em 22/6/2016).
} 
revogado pela Constituição de 1988. Entre outras exigências mais amplas, ia a pormenores, determinando, por exemplo, que nos dez primeiros dias de cada ano todos os empresários teatrais deveriam mandar quatro ingressos permanentes aos censores, cujos lugares seriam obrigatoriamente nas três primeiras filas da plateia, "em posição de visibilidade e audição completas". Sobre o ensaio geral, definia que deveria se realizar em data e hora marcados pelos censores, que passaram a escolher a véspera da estreia a fim de tornar o processo ainda mais angustiante para os produtores ${ }^{184}$.

Armados desse arcabouço legal, os censores do governo Lacerda compareceram ao Teatro Princesa Isabel na tarde de 21 de julho de 1965 para assistir ao ensaio de "O Berço do Herói”. A ordem dos diretores para os atores tinha sido de amenizar o tom ácido ao máximo, e algumas passagens foram modificadas com o objetivo de evitar problemas $^{185}$.

Os censores estavam acompanhados de mais quatro homens, que não se identificaram aos produtores. Ao terminar a apresentação, Dias Gomes perguntou a eles se a peça havia sido aprovada. Uma censora respondeu que o veredito seria dado "só amanhã". O autor argumentou que isso seria complicado, pois a estreia estava marcada para o dia seguinte. Ela olhou para o grupo que a acompanhava, voltou-se ao dramaturgo e repetiu que "só amanhã" a Censura daria uma resposta.

A primeira apresentação ao público seria às 21:30 horas de 22 de julho de 1965. Às 17 horas, o chefe do Serviço de Censura do Rio, Asdrúbal Sodré Júnior, assinou um documento vetando o espetáculo ${ }^{186}$. Por volta das 21 horas, compareceu à porta do teatro Princesa Isabel, que havia sido inaugurado seis meses antes, pelo governador Carlos Lacerda, em homenagem ao quarto centenário do Rio. Lá, encontrou dezenas de espectadores que não sabiam da proibição. Dias Gomes e a equipe do espetáculo também estavam no local, o que gerou tensão, pois o censor julgou que eles pretendiam encenar a peça à revelia. Por isso, ameaçou chamar a polícia.

\footnotetext{
184 Informações sobre a legis lação da censura foram tirados do site da Câmara dos Deputados (camara.gov.br) e de KUSHNIR, Beatriz. Cães de Guarda - Jornalistas e censores do AI-5 à Constituição de 1988. São Paulo: Boitempo, 2004.

185 Informação dada à autora pelo ator Sebastião Vasconcelos.

$186 \mathrm{O}$ documento original da censura da peça possivelmente foi extraviado. Não está no acervo do Arquivo Geral do Estado do Rio de Janeiro nem no Arquivo Nacional, que centraliza o fundo documental da Divisão de Censura de Diversões Públicas; este contém documentação de pedidos de montagens posteriores, a que esta pesquisa teve aces so. O relato do que se pas sou com a censura foi publicado por Dias Gomes em artigo na "Revista Civilização Brasileira", nº 4, edição de setembro de 1965.
} 
Um diálogo que Dias Gomes considerou "kafkiano" se deu quando ele explicou a Sodré Júnior que pretendia apenas informar o público sobre a proibição da peça:

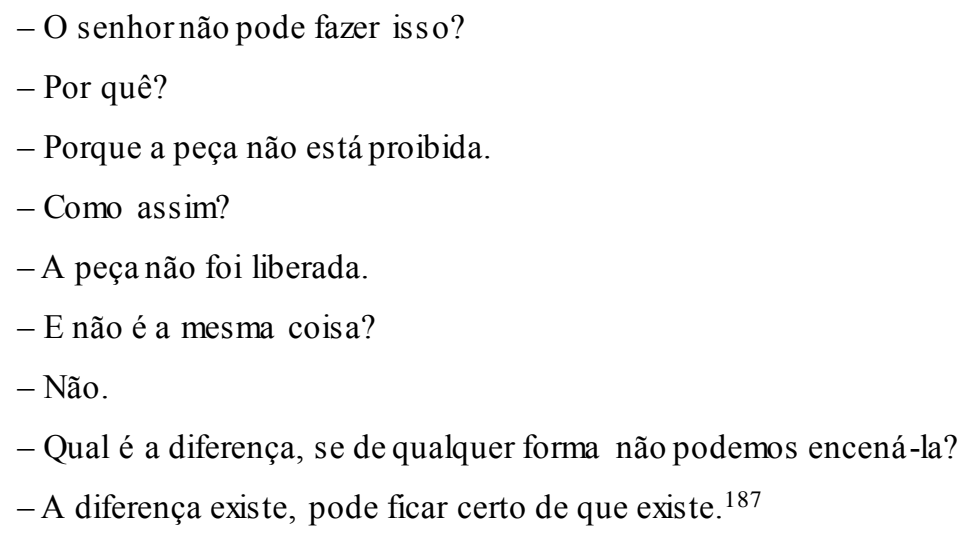

Mais tarde, chegariam dois censores "mais amáveis, simpáticos e compreensivos", de acordo com relato que Dias Gomes faria em setembro, em artigo na "Revista Civilização Brasileira". No texto, os nomeou de Sr. Machado e Sr. Ottati, este último José Leite Ottati, que viria a ser contratado na década de 1970 pela TV Globo para fazer o meio de campo entre a emissora e a censura.

O Sr. Ottati e o Sr. Machado explicaram que a proibição ocorrera porque, no ensaio, os censores observaram modificações em relação ao texto aprovado anteriormente. Ottati mostrou a Dias Gomes o que deveria ser alterado para que a peça fosse aprovada: 1) Mudar a cor do pano verde e amarelo que cobria a estátua do herói; 2) Chamar o "General" de "Emissário do Ministério da Guerra", e o "Major", de "Deputado"; 3) Alterar a sigla IPM, que significa Inquérito Policial Militar, pela palavra "inquérito"; 4) Suprimir a localização da ação, riscando do texto Brasil, Salvador e Rio de Janeiro.

O autor se propôs a fazer as mudanças e, no dia seguinte, às 15 horas, compareceu ao gabinete da Superintendência da Polícia Judiciária. Deu-se nova conversa com ar "surrealista e kafkiano", como avaliou Dias Gomes, entre ele e o superintende, Sales Guerra, segundo relato do autor:

$$
\begin{aligned}
& \text { - A peça está proibida. } \\
& \text { - Mas o texto não foi aprovado pela Censura? }
\end{aligned}
$$

187 GOMES, Dias. O Berço do Herói e as armas do Carlos. Revista Civilização Brasileira. Ano 1, n. 4, 9/1965, apud. GOMES, Dias (1998). Apenas um subversivo. Rio de Janeiro: Bertrand Brasil, p. 217 
- Foi.

- Por que então a proibição?

- Porque o texto sofreu alterações durante o ensaio.

- Mas isto é comum.

- Mas não pode. Não está de acordo com o texto aprovado.

- Podemos levar então o texto aprovado?

- Não.

- Por quê?!

- Porque fizeram alterações no texto aprovado.

- Suprimimos as alterações. Levamos o original, sem mudar uma vírgula. Podemos?

- Não.

- Por quê?!

- Porque o original foi alterado. ${ }^{188}$

O embate tornou-se algo mais esclarecedor quando o chefe de Censura, Asdrúbal Sodré Júnior, que assinara a proibição na véspera, resolveu falar:

- Os senhores infringiram o artigo 41 do regulamento.

- Perdoe-me a ignorância, mas não conheço esse artigo. O senhor poderia talvez esclarecer-me sobre o seu texto.

- Que texto?

- $\mathrm{O}$ texto do artigo 41.

- Ah, não sei. Também não sou obrigado a saber de cor todos os artigos de todas as leis.

- Mas o chefe da Censura deve saber.

- Eu? Por quê?

- Porque o senhoré o chefe da Censura.

- Quem aplica o artigo é o censor, no parecer.

- E o parecer? Posso ver o parecer?

- Não. O parecer é confidencial.

- Mas eu preciso saber de que me acusam.

- O senhoré acusado de ter infringido o artigo 41. Não basta? 189

Dias Gomes não pôde ver o parecer e ele provavelmente se extraviou posteriormente dos arquivos oficiais - não foi localizado para esta pesquisa no Arquivo

\footnotetext{
188 Ibidem, p. 215
}

189 Ibidem, p. 216 
Nacional do Ministério da Justiça, que guarda o acervo da Divisão de Censura de Diversões Públicas, nem no Arquivo do Estado do Rio de Janeiro -por sorte, o autor foi detalhista ao abordar o processo censório em artigo que publicou na "Revista Civilização Brasileira", e a imprensa, ainda não censurada previamente, registrou passagens do episódio.

Naquela tarde de 23 de julho de 1965, uma sexta-feira e "aniversário" de um ano do decreto que o demitiu da Rádio Nacional, o autor saiu da Polícia Judiciária sem esperança de estrear "O Berço do Herói”' ainda no final de semana. O superintendente The disse que somente na segunda-feira poderia dar uma resposta de seu recurso para encenar a peça com o texto original.

No final de semana, o elenco, caracterizado com os personagens, pegou um táxi na porta do teatro e foi até a praia do Flamengo, na porta do apartamento tríplex do governador, que não concordou em receber os artistas ${ }^{190}$. Por trás da fúria de Lacerda contra Dias Gomes e tudo o que girava em torno do PCB, estava a sua complexa relação com o comunismo. Como escreve Otavio Frias Filho no artigo "O Tribuno da Imprensa", na revista "Piauí", "antes de se tornar o símbolo máximo da direita ideológica no panorama político da segunda metade do século passado, Carlos Lacerda foi um promissor militante de esquerda no Rio de Janeiro". Nascido em 1914, ganhou o nome de Carlos Frederico Werneck de Lacerda "em homenagem aos prenomes de Marx e Engels". Frias Filho ressalta as credenciais familiares do governador, que chegou a se destacar nos movimentos de rua esquerdistas no início do século 20 :

O avô, Sebastião de Lacerda, ministro de tendências liberais no Supremo Tribunal Federal, havia sido abolicionista e republicano na juventude (...). Seu pai, Maurício de Lacerda (um "socialista romântico", na definição do filho), deputado radical ligado ao florescente sindicalismo dos anos 10 e 20, teve atuação destacada nos comícios que forçaram a deposição de Washington Luís e o fim da República Velha em 30. (...) Aos 12 anos, leu “ABC do Comunismo”, de Nikolai Bukharin, presente de seu tio Paulo, irmão caçula do pai. Paulo e Fernando, o irmão do meio, foram dirigentes do Partido Comunista Brasileiro (...). Na faculdade de direito, Lacerda se

\footnotetext{
${ }^{190}$ Dias Gomes não precisou a data do encontro no artigo da "Revista Civilização Brasileira", publicado em setembro. Nota da "Folha de S.Paulo" de 26 de julho de 1965, uma segunda-feira, registra que o governadorse recusou a receber o elenco da peça que havia ido procurá-lo em sua residência. A informação de que os artistas estavam caracterizados é do artigo de Dias Gomes e a de que saíram de táxi da porta do teatro, de entrevista à autora de Sebastião Vasconcelos.
} 
aproximou de professores socialistas e escreveu seu primeiro livro, "O Quilombo de Manuel Congo", panfleto em que exaltava uma revolta de escravos (...). Foi preso ao menos quatro vezes pela polícia entre 33 e 39.191

Foi na atividade jornalística que o jovem Lacerda, aos 23 anos, acabou expulso do Partido Comunista, em uma controversa passagem da história brasileira. O Estado Novo encomendou a uma revista mensal em que Lacerda trabalhava um artigo sobre o "comunismo e sua derrota". Como ele conhecesse bem o Partido, foi escolhido a escrever o texto e, conforme relata Frias Filho, consultou o Partido, "que o achou preferível a algum articulista hostil”. O texto foi publicado em janeiro de 1939, com detalhes sobre a organização e o nome de vários membros importantes. Lacerda alegou que as informações já eram de conhecimento da polícia e se recusou a fazer uma retratação exigida pelo Partido. Assim, "foi esmagado por uma condenação imediata, subterrânea, infamante", descreve Frias Filho. "Em torno do Partido girava uma numerosa camada de simpatizantes (...), intelectuais, jornalistas, artistas, boêmios, o mundo em que Lacerda sempre vivera. Da noite para o dia, amigos recusavam-se a the dirigir a palavra."192

Foi carregado desse passado que Lacerda se deparou com o elenco de "O Berço do Herói” naquele julho de 1965, que o esperou plantado, até que ele foi obrigado a sair de casa para um compromisso. Entre os artistas estavam Ana Maria Nabuco, Ilva Niño e os protagonistas Sebastião Vasconcelos (Major Chico Manga) e Tereza Rachel (Viúva Antonieta). A memória da atriz registra brutalidade por parte de Lacerda, que, tentando se desvencilhar do grupo, chegou a segurá-la pelo braço e a empurrá-la ${ }^{193}$. Entre ele e os atores, de acordo com Dias Gomes, deu-se o seguinte diálogo:

- Já sei, vocês vêm falar de "O Berço do Herói”. Não adianta. Li a peça. É pornográfica e subversiva. Fui eu que mandei proibi-la.

- Mas, governador, a peça havia sido aprovada pela Censura.

- Eu sei. Mas enquanto houver Constituição neste País, peças desse tipo não serão permitidas. De agora em diante, vou ler todas e proibir uma por uma. Há algumas em cartaz que já deveriam ter sido proibidas. A do

${ }^{191}$ FRIAS FILHOS, Otavio. O tribuno da imprensa. Revista Piauí, n. 91, 2014

192 Ibidem

${ }^{193}$ Entrevista da atriz Tereza Rachel à autora em 2/9/2011. 
Nelson Rodrigues, por exemplo. Mas essa é só pornográfica. Dias Gomes é pior, é também subversivo. E vão embora daqui. ${ }^{194}$

A peça de Rodrigues em cartaz era "Toda Nudez Será Castigada", que estreara no Teatro Serrador, em 21 de junho. A comparação com seu desafeto irritou ainda mais Dias Gomes, que se inspiraria nessa declaração de Lacerda para, 33 anos depois, em 1998, dar à sua autobiografia o nome de "Apenas um Subversivo", na qual afirma que na primeira versão da peça "O Bem-Amado", de 1962, o linguajar do populista e corrupto prefeito Odorico Paraguaçu era uma caricatura "do hiperbólico estilo oratório" do governador $^{195}$.

O final do sermão que Lacerda passou no grupo de atores, pouco antes de entrar em seu carro oficial, é simbólico da percepção que o poder tinha da produção cultural: “Se querem fazer a revolução, peguem em armas!", bradou -e aqui vale voltar à já mencionada frase do nazista alemão Goering, citada por Paulo Francis no prefácio do livro “O Berço do Herói”: "Quando ouço falar em cultura, sinto vontade de sacar o revólver".

A censura à peça do mito do falso herói mobilizou o meio cultural no País. Diversas mensagens de apoio chegaram a Dias Gomes e a toda a equipe da peça, e grupos dedicaram suas encenações à obra censurada. No sábado, dia 24 de julho, dois dias após à não-estreia, quem resolveu abraçar a causa foi o respeitado advogado Sobral Pinto -o mesmo que em 1949 havia ajudado o amigo católico Carlos Lacerda a fundar a “Tribuna da Imprensa” e que em 1964 apoiara a intervenção militar para afugentar o comunismo do Brasil. Conhecido pela retidão na conduta e por nunca trair suas convicções, uma semana depois do golpe, mandou uma carta ao presidente Castello Branco dizendo que ele não tinha legitimidade para governar o País, pois não havia sido escolhido pelo povo e, portanto, sua presidência era inconstitucional ${ }^{196}$.

O jurista passou a defender Dias Gomes, o comunista que 12 anos antes, em 1953, cometera o "crime" de viajar a Moscou e fora demitido por Lacerda com a ajuda do jornal que Sobral ajudara a fundar. Independentemente de quem estava de um lado

\footnotetext{
${ }^{194}$ GOMES, Dias. O Berço do Herói e as armas do Carlos. Revista Civilização Brasileira. Ano 1, n. 4, 9/1965, apud. GOMES, Dias (1998). Apenas um subversivo. Rio de Janeiro: Bertrand Brasil, p. 219-220 195 GOMES, Dias. Apenas um subversivo. Rio de Janeiro: Bertrand Brasil, 1998, p. 187 196 Informação do documentário "Sobral Pinto - O Homem que não Tinha Preço" (2013; direção Paula Fiúza).
} 
ou de outro, o novo embate se dá em torno da censura ${ }^{197}$, e Sobral Pinto entrou em cena porque acreditava no direito inquestionável à liberdade de expressão. A ele, um nome respeitado pela direita, os censores passaram a dizer que a peça seria liberada, era só questão de tempo. O advogado, que assumia processos dessa natureza muitas vezes sem cobrar honorários, pediu paciência aos produtores.

Apesar de o superintendente da Polícia Judiciária ter dado parecer favorável à peça, a liberação não saía, e os dias se passavam. Durante duas semanas, o elenco se aprontou, com figurino e maquiagem, para a estreia que nunca acontecia. Eles então perceberam que a demora fazia parte de outro tentáculo da censura: a do sufocamento econômico das produções culturais. Sem o lucro da bilheteria, os profissionais não recebiam e eram obrigados a partir para outros projetos ${ }^{198}$.

No dia 5 de agosto, 14 dias após a censura, a "Folha de S.Paulo" voltou ao assunto pela quarta vez, a primeira de forma opinativa. Um artigo na capa da "Ilustrada" condenando a censura à "O Berço do Herói” era assinado pelo ensaísta e crítico literário Tristão de Ataíde. Trata-se de pseudônimo de Alceu de Amoroso Lima, um dos fundadores da Pontifícia Universidade Católica, do grupo de católicos influentes, formado também por Sobral Pinto, e que também ajudara Lacerda a fundar a "Tribuna da Imprensa" em 1949. O texto da "Folha" tem como título "O Trigo e o Joio". Nele, o autor faz um comparação entre a censura -que determina autoritariamente o que é trigo e o que é joio, para aniquilar o segundo- e a parábola cristã, que tem como princípio a liberdade e permite que os dois cresçam lado a lado para que, "a seu tempo, sejam distinguidos, e o bem possa vencer o mal". Ele, que havia assistido a um ensaio de "O Berço do Herói”, não gostara da peça, o que relata no artigo. "Mas pouco importa se ela é teatralmente fraca" porque o "terrorismo cultural dos censores transcende o caso particular da peça de Dias Gomes".

Quem cunha a expressão "terrorismo cultural”, como nos lembra Napolitano, é justamente um liberal. E, por isso, a censura a “O Berço do Herói” e esse texto de Alceu

\footnotetext{
${ }^{197}$ Vale aqui lembrar que, paradoxalmente a essa postura de Lacerda com o teatro, o governador teve participação no fomento ao cinema, inclusive ao Cinema Novo. Em 1963, criou a Comissão de Auxílio à Indústria Cinematográfica (Caic), que taxava segmentos da diversão como teatro e circo para financiar a produção de filmes. Por um lado, após pressão da Igreja, tirou de cartaz "Os Cafajestes" (1962), de Ruy Guerra, dez dias após a estreia e já com um público de dois milhões de espectadores; poroutro, premiou "Vidas Secas" (1963), de Nelson Pereira dos Santos, entre outras produçõ es. $198 \mathrm{O}$ ator Clóvis Bueno, em entrevista à autora em 2/9/2011, afirmou que o elenco os produtores não puderam pagar o elenco.
} 
Amoroso Lima, assim como o engajamento de Sobral Pinto na causa, se mostram chave para o entendimento de algo que se passou logo nos primeiros instantes da ditadura: a falta de liberdade de expressão tornou-se o epicentro da tensão criada entre os militares e os liberais, que pouco antes, em grande parte, haviam apoiado o golpe. A partir daí, a expressão "terrorismo cultural" seria endossada pelo Partido Comunista, que começava já a falar em uma coalizão dos "setores democráticos contra a ditadura". "Firmava-se, assim, no campo da cultura, uma aliança entre setores de esquerda (pecebista) e do liberalismo na busca de uma frente de oposição ao regime"199.

A censura, se por um lado seria eficiente para evitar a circulação de ideias não favoráveis ao governo, por outro, acabaria como um tiro no pé. E ela foi só uma das pontas do que Napolitano chama de "tripé repressivo" do regime em relação à produção cultural. Nas outras duas pontas estão a produção de informações e a vigilânciarepressão, ambas a cargo das Delegacias de Ordem Política e Social (Dops), das inteligências militares e do sistema Codi-Doi (Centro de Operações de Defesa Interna Destacamento de Operações e Informações).

Nos primeiros quatro anos da ditadura, o "objetivo principal era dissolver as conexões entre a 'cultura de esquerda' e as classes populares, estratégia manifestada no fechamento do CPC [Centro Popular de Cultura, da UNE], do Iseb [Instituto Superior de Estudos Brasileiros] e dos movimentos de alfabetização de base". A pressão, além da censura direta, se dava por meio dos IPMs (Inquéritos Policiais-Militares) e de processos judiciais, 'implantando o chamado 'terror cultural', que transforma va todos os intelectuais críticos em potenciais subversivos 'inimigos da Pátria'.

Ainda que os resultados práticos dos IPMs tenham sido pífios, em termos de punições efetivas, para desgosto da "linha dura", causaram bastante insegurança entre intelectuais de vários matizes, alimentando a imagem do regime como uma 'ditadura obscurantista e anticultural'. Esta perspectiva alimentou a aliança de vários setores intelectuais -liberais, socialistas e comunistas-, reforçando uma cultura de oposição ${ }^{200}$.

199 NAPOLITANO, Marcos. 1964 - His tória do regime militar brasileiro. São Paulo: Contexto, 2014, p. 104

${ }^{200}$ Ibidem, p. 100 
A repercussão em torno da proibição de "O Berço do Herói” crescia. Foi tornada pública uma carta, com 1.500 assinaturas, dirigida ao presidente Castello Branco que defendia que a proibição de uma peça com texto já aprovado pela Censura era algo inconstitucional. A classe teatral do Rio reuniu-se em assembleia para decidir como agir. Entre as várias propostas, uma delas foi a de que parte de uma obscura peça de Lacerda fosse encenada antes de todos os espetáculos. Irônico como sempre, Dias Gomes escreveu em seu artigo da "Civilização Brasileira" que isso não foi aprovado "porque resultaria na punição de um inocente: o público". Acabou vencendo a ideia de fazer uma noite de vigília em frente ao Teatro Princesa Isabel, que contou também com a presença de jornalistas, cineastas, músicos etc.

A polêmica chegou aos discursos do Congresso, e o governo estadual achou por bem se manifestar, divulgando um despacho do secretário de Segurança Pública, Gustavo Borges. A secretaria havia sido criada três anos antes, em 1962, por lei assinada por Lacerda, que reestruturava o Estado na Guanabara após a transferência da capital federal para Brasília, em 1960. Borges era o primeiro a ocupar o cargo ${ }^{201}$.

O documento assinado por ele acusava os produtores de terem feito alterações no texto aprovado pela Censura, de forma premeditada, já vislumbrando um choque com censores. O objetivo seria usar a polícia para fazer "propaganda gratuita" em notícias "pré-fabricadas visando demonstrar que o 'terrorismo cultural' [e aqui ele cita o termo publicado dias antes em artigo de Tristão de Ataíde na "Folha"] vem sendo aplicado pelas autoridades". "A verdade", no entanto, afirmava o secretário de segurança, é que “esses senhores estão engajados na implantação de uma ditadura cultural, através do abuso da liberdade democrática e em estrita obediência à recente diretriz do PCB”.

O despacho prosseguia com a operação de demonstrar que a censura era legal conforme aponta Kushnir, a ditadura militar e outros períodos de exceção na história brasileira tiveram a preocupação de criar um aparato jurídico a fim de dar aos atos de arbítrio aparência de legalidade ${ }^{202}$. Voltava à cena no despacho de Borges o decreto 20.493, de 1946, que sobreviveria por mais de quatro décadas, em períodos ditatoriais e democráticos, até a Constituição de 1988. Com base nele, o secretário de segurança aplicou aos produtores de “O Berço do Herói” multa de Cr\$1.000, “uma vez que os

\footnotetext{
${ }^{201}$ Informação da Secretaria de Segurança Pública e de Gustavo Borges está no site da Polícia Civil do Rio de Janeiro. (policiacivil.rj.gov.br)

${ }^{202}$ KUSHNIR, Beatriz. Cães de Guarda - Jornalistas e censores do AI-5 à Constituição de 1988. São Paulo: Boitempo, 2004, p. 81
} 
artistas não observaram o que fora aprovado pela Censura". Citou o artigo 50 da lei, o qual obrigava os artistas, no ensaio geral, a seguir as determinações do censor 'tanto em relação ao texto, como em relação à indumentária, aos gestos, marcações, atitudes e procedimentos no palco". Era o censor se fazendo de diretor.

Além da multa, a proibição ficou clara quando ele escreveu que se "reprove totalmente" a exibição da peça, mencionando então o tal do artigo 41 do regulamento, que o chefe da Censura não sabia de cor na conversa com Dias Gomes. De acordo com os oito pontos desse artigo, será negada a autorização sempre que a obra:
a) contiver qualquer ofensa ao decoro público;
b) contiver cenas de ferocidade ou for capaz de sugerir a prática de crimes;

c) divulgar ou induzir aos maus costumes;

d) for capaz de provocar incitamento contra o regime vigente, a ordem pública, as autoridades constituídas e seus agentes;

e) puder prejudicar a cordialidade das relações com outros povos;

f) for ofensivo às coletividades ou às religiões;

g) ferir, por qualquer forma, a dignidade ou o interesse nacionais;

h) induzir ao desprestígio das forças armadas. ${ }^{203}$

O coronel Borges pontuou os supostos problemas do texto, relacionando-os com cada um dos itens previstos na lei. A peça, disse, fere a alínea "c", sobre os maus costumes, ao "glorificar o lenocínio e a corrupção dos costumes". Lenocínio, em outras palavras, é exploração da prostituição -em Cabo Jorge, há uma "casa de raparigas". Também acusava de ofender o decoro público, previsto na alínea "a", "pelo emprego de palavras de baixo calão". E os censores se deram ao trabalho de contá-las: "34 vezes". "O Berço do Herói”, de acordo com o despacho, ofende as religiões, o que é vetado pela alínea 'œ”, “ao fazer grosseiras e intempestivas referências à Virgem Santíssima e ao apresentar o vigário em dança grotesca". E, de novo, valeu-se de base quantitativa: "Além de 23 referências antirreligiosas".

A referência à Virgem Santíssima aparece em diálogo entre Chico Manga e um personagem chamado Florindo, que jura pela "Virgem Santíssima" não ter roubado um certo dinheiro, ao que o outro retruca: "Não meta a Virgem nessa história, senão vão

\footnotetext{
203 Câmara dos Deputados (http://www2.camara.leg.br/legin/fed/decret/1940-1949/decreto-20493-24janeiro-1946-329043-publicacaooriginal-1-pe.html; acesso em 22/6/2016)
} 
acabar duvidando da virgindade dela". Já o vigário dança em torno da estátua de Cabo Jorge, na praça central, ao lado do Prefeito, do Major e do Vendedor, todos com barrigas grandes, ao som do coro: “À sombra desta estátua / uma cidade cresceu, / cresceu, cresceu, cresceu, / à sombra dela cresceu. / Barriga também cresceu / de muita gente cresceu."

Até aí, a Censura estava tratando de questões, no dizer de Lacerda, "pornográficas". É bom lembrar que esse tipo de censura moral costuma encobrir o verdadeiro sentido dos vetos, sempre político, como nos alerta Kushnir. A capa do "resguardo à moral e aos bons costumes" reveste o ato censório "de um suposto movimento pendular entre o direito à liberdade e o risco de abuso". Dessa forma, a censura se dá, inclusive em períodos democráticos, como o apoio de setores da sociedade, que não só a desejam como a exigem ${ }^{204}$.

A essência da censura pós-1964, na verdade, gira em torno Doutrina da Segurança Nacional, que surgiu durante a Guerra Fria, a partir da política anticomunista do Conselho de Segurança Nacional dos Estados Unidos -por sua vez, pautada pela Doutrina Truman, de combate ao comunismo internacional. No Brasil, foi propagada pela Escola Superior de Guerra e orientou, a partir do golpe, a elaboração de toda a estrutura de repressão, do SNI e o Dops (Departamento de Ordem Política e Social) à censura. Também é a base da reorganização do Departamento Federal de Segurança Pública, determinado pela lei 4.483, de 16 de novembro de 1964, que mescla a censura às diversões públicas ao combate aos inimigos dos "interesses da União".

No despacho sobre "O Berço do Herói”, o secretário de Segurança Pública deixou para a última linha a preocupação com a parte "subversiva" da obra. O problema estava em infringir a alínea " $h$ ", que proíbe a indução do desprestígio às Forças Armadas, ao "ridicularizar um herói da FEB [Força Expedicionária Brasileira], além de várias outras aleivosias [traições]". Em seu artigo publicado em setembro na "Civilização Brasileira”, Dias Gomes tenta responder o despacho ponto a ponto, citando inclusive o artigo de Tristão de Athaíde. Na autobiografia, diz saber que a questão central era a ridicularização do herói da FEB, que não foi aceita pelos militares.

Não adiantava espernear, a peça seguiria proibida. Porque Dias Gomes não se contentava em ser pornográfico. Ele insistia em ser subversivo, e isso já era demais.

\footnotetext{
${ }^{204}$ KUSHNIR, Beatriz. Cães de Guarda - Jornalistas e censores do AI-5 à Constituição de 1988. São Paulo: Boitempo, 2004, p. 131
} 
Três meses antes da censura à “O Berço do Heróí, no dia 26 de abril de 1965, entrava no ar a TV Globo, no canal 4 do Rio de Janeiro, 15 anos após a primeira transmissão de televisão no Brasil, em 1950, pela Tupi de São Paulo. A emissora de Roberto Marinho, dono do jornal "O Globo", era tocada nesses primeiros meses por funcionários da Rádio Globo, entre eles o general Lauro Medeiros (ex-chefe das comunicações do Exército, tornou-se diretor técnico do novo canal), o locutor Rubens Amaral (que disse as primeiras palavras no ar e assumiu a direção-geral), e Mauro Salles (diretor de jornalismo). Desse primeiro grupo fazia parte também Moysés Weltman, o amigo comunista de Dias Gomes, que se tornaria responsável pela programação artística da TV, para a qual iria indicar, entre outros nomes, o da novelista Janete Clair. Enquanto os militares demitiam o escritor da Rádio Nacional e o vetavam no teatro, o pequeno estúdio de televisão do Jardim Botânico se preparava para ser o cenário do segundo ato da saga do falso herói e de sua luta contra a censura. 


\title{
3. SEGUNDO ATO
}

\author{
Hoje não tem novela
} "Roque Santeiro" 1 


\subsection{Capítulo 4 \\ $O$ veículo subversivo}

"Foi instalada a antena que vai levar pioneiramente aos lares paulistas o mais subversivo de todos os veículos de comunicação." Quinze anos antes de Dias Gomes ser chamado de subversivo por Carlos Lacerda em razão da peça de teatro "O Berço do Herói”, no Rio, o adjetivo era usado por Assis Chateaubriand, em São Paulo, para se referir à grande novidade que ele trazia ao Brasil: a televisão. A frase estava no discurso proferido pelo dono dos Diários Associados a políticos, empresários, técnicos e artistas, em um estúdio do bairro do Sumaré, poucas horas antes de ser transmitido de lá, no dia 18 de setembro de 1950, a programação inaugural da primeira emissora de TV da América Latina, a Tupi.

Havia em todo o mundo apenas três estações de televisão -na França, na Inglaterra e nos Estados Unidos-, e a suposta subversão a que Chatô se referia estaria disponível no Brasil para os 200 presenteados por ele, entre eles o presidente Dutra, com televisores que havia contrabandeado para o País. Quase um ano depois, em 20 de janeiro de 1951, entrou no ar a estação carioca da Tupi. Apesar da empolgação diante da nova mídia, o empresário gabava-se, em 1952, do fato de a revista "O Cruzeiro", de seu grupo empresarial, com a vendagem de 550 mil exemplares -na edição da cobertura da morte do popular cantor Francisco Alves, em um acidente de carro da Via Dutra, no dia 27 de setembro- ter quase dez vezes mais leitores do que a soma de telespectadores das suas duas estações de $\mathrm{TV}^{205}$.

Até 1960, a Tupi ganharia alguns concorrentes, e o mercado começaria a se formar aos poucos: em São Paulo, a TV Paulista (1952) e a Record (1953), e as cariocas TV Rio (1955) e TV Continental (1959). Ainda dos Diários Associados seriam inauguradas a TV Itacolomi (1955), em Belo Horizonte, e a TV Cultura de São Paulo (1960), que depois, em 1969, passaria às mãos do governo do Estado.

O rádio, entretanto, era ainda o grande veículo de comunicação de massa do País, e a penetração da televisão caminharia a passos lentos. Dez anos após a inauguração, em 1960, existiam apenas 598 mil aparelhos no País, menos de 1\% da população, segundo dados da Abinee, a associação de fabricantes. O censo do IBGE apontou nesse ano que

${ }^{205}$ MORAIS, Fernando. Chatô: o rei do Brasil. São Paulo: Companhia das Letras, 1994, p. 502 
$4,3 \%$ dos domicílios possuíam televisores, ante $35 \%$ com rádio -o número torna-se um pouco mais relevante se considerarmos as residências urbanas, mas ainda baixo: 9,5\% com TV, contra $61 \%$ aparelhados com rádio ${ }^{206}$.

Apesar disso, já em 1961, Lacerda percebeu o potencial político do "veículo subversivo". Acostumado a conduzir agressivas campanhas contra seus inimigos primeiro na imprensa escrita e depois no rádio, "fez um pronunciamento nos estúdios da TV Excelsior do Rio acusando o então presidente Jânio Quadros de estar preparando um golpe de Estado". Sobre o episódio, Inimá Simões comenta:

O discurso, virulento, não provocou a renúncia de Jânio, até porque sua transmissão ficou nos limites da Cidade Maravilhosa, mas mostrou que a TV já era um meio expressivo o suficiente para se mandar recados políticos, atacar opositores e mobilizar a opinião pública. Lacerda foi o nosso primeiro político a reconhecer a força da TV para conquistar corações e mentes, fato confirmado nas eleições dos Estados Unidos em que os candidatos Richard Nixon e John Kennedy se confrontaram diante das câmeras [1960] $]^{207}$.

Antes disso, em 1959, o presidente Juscelino Kubitschek já alertara Armando Falcão, no momento em que o convidou para ser seu ministro da Justiça, do perigo: "Ministro, por favor, nunca perca de vista o Lacerda. Se deixarmos à disposição dele a televisão e o rádio, depressa vamos acabar no chão" ${ }^{208}$. E, em uma demonstração de que a censura não é restrita a períodos ditatoriais, Falcão logo passou a "ter encontros regulares com os responsáveis pela programação política e jornalística" das emissoras de TV, de forma a controlar a lista dos entrevistados, "delas excluindo", conforme admitiu, os "radicais e os demolidores".

A partir de 1964, os militares demonstrariam saber como ninguém dessa "força para conquistar corações e mentes" da TV e do perigo de "acabar no chão" se a deixasse com os "demolidores". Assim, a penetração do veículo subversivo de Chatô, sempre sob

\footnotetext{
206 Para a quantidade total de aparelhos no país em 1960, dados da Abinee (Associação Brasileira de Indústria Elétrica e Eletrônica) citados em RAMOS, José Mário Ortiz; BORELLI, Silvia H. Simões. A telenovela diária. In: ORTIZ. Renato; BORELLI, Silvia Helena Simões; RA MOS, José Mário Ortiz. Telenovela - his tória e produção, 2a edição. São Paulo: Editora Brasiliense, 1991, p. 55; dados do censo de 1960 do IBGE estão em CALABRE, Lia. A participação do rádio no cotidiano da sociedade brasileira (1923-1960). Rio de Janeiro: Fundação Casa de Rui Barbosa, sd.

${ }^{207}$ SIMÕES, Inimá. Nunca fui santa (episódios de censura e autocensura). In: BUCCI, Eugênio (org.). A TV aos 50. São Paulo: Editora Fundação Perseu Abramo, 2000, p. 46

${ }^{208}$ FALCÃO, Armando. Tudo a declarar. São Paulo: Nova Fronteira, 1989, p. 355
} 
controle do Estado, só iria se ampliar. No ano do golpe, havia no País pouco mais de 1,6 milhão de televisores. O crescimento, fomentado por incentivos do governo, que em 1965 inaugurou a Embratel, facilitando as transmissões, seria exponencial: 4,9 milhões em 1970; 10,2 milhões em 1975 e 19,6 milhões em 1980209. No mercado public itário, a participação da TV entre o total de anúncios, que havia sido de $1 \%$ no ano da inauguração, iria se tornar líder dentre todos os veículos em 1963, com 32,9\%. Em 1964, somou $36 \%$, ante $23,4 \%$ do rádio, $19,5 \%$ das revistas e $16,4 \%$ dos jornais ${ }^{210}$.

Foi na instalação da ditadura que a telenovela, veiculada desde 1951, se consolidou como o grande gênero da TV brasileira, sendo chamada na imprensa de "mania nacional" e de "doce epidemia"211. Em 1964, 31 estrearam, e a Colgate Palmolive, que patrocinava produções, contratou para o seu departamento de televisão no Brasil a cubana Gloria Magadan, que fazia novelas na Telemundo, canal hispânico dos Estados Unidos. No ano anterior, quando Dias Gomes escreveu a peça "O Berço do Herói”, havia entrado no ar a primeira telenovela brasileira diária, o que se tornou possível graças à chegada do videoteipe -desde 1951, quando foi lançada a primeira do País, "Sua Vida me Pertence", elas eram apresentadas ao vivo, o que dificultava a exibição todos os dias. Com Tarcísio Meira e Glória Menezes como o casal protagonista, "2-5499 Ocupado" se iniciou em 22 de julho de 1963, ainda exibida às segundas, quartas e sextas. Ao longo dos capítulos e com o sucesso de audiência, a Excelsior decidiu torná-la diária ${ }^{212}$ e o romance televisivo chegou à liderança no Ibope, o que fez a emissora, em 1964, colocar três novelas na programação -a concorrente, a Tupi, chegou a ter quatro histórias no ar simultaneamente. Diante do crescimento, era preciso investir em contratações, e foi nesse fatídico ano da história do País que Janete Clair, já famosa autora de radionovelas, estreou na TV. Entre setembro e dezembro de

\footnotetext{
${ }^{209}$ Dados da Abinee em RAMOS, José Mário Ortiz; BORELLI, Silvia H. Simões. A telenovela diária. In: ORTIZ. Renato; BORELLI, Silvia Helena Simões; RA MOS, José Mário Ortiz. Telenovela - história e produção, 2 $2^{a}$ edição. São Paulo: Editora Brasiliense, 1991, p. 81.

${ }^{210}$ Dados da Thompson, com as 30 maiores agência, citados em MICELI, Sergio. A noite da madrinha. São Paulo: Companhia das Letras, 2005, p. 294.

211 RAMOS, José Mário Ortiz; BORELLI, Silvia H. Simões. A telenovela diária. In: ORTIZ. Renato; BORELLI, Silvia Helena Simões; RA MOS, José Mário Ortiz. Telenovela - história e produção, $2^{\text {a }}$ edição. São Paulo: Editora Brasiliense, 1991, p. 62

212 Teledramaturgia.com.br
} 
1964, a Tupi do Rio veiculou “O Acusador”, uma trama policial que se passa no interior de Pernambuco sobre dois gêmeos, em que um assume o lugar do outro ${ }^{213}$.

Enquanto a telenovela inaugural de Janete Clair terminava, entrava no ar, em 7 de dezembro, o drama que pela primeira vez mostraria a capacidade desse formato para conquistar corações e mentes no Brasil: "O Direito de Nascer", sobre o filho bastardo de uma moça rica que é criado pela empregada negra sem saber de nada. $\mathrm{O}$ original cubano de 1946 foi comprado por Boni, ex-estagiário de Dias Gomes na Rádio Clube que dava seus primeiros passos na TV, e por Walter Clark, ambos empregados da TV Rio na ocasião. Uma mala com US\$ 5.000 foi entregue ao autor, Félix Caignet, no México, por Dercy Gonçalves, que voltou com outra lotada com as folhas dos roteiros. Como a TV Rio não quis produzir a novela, Boni e Clark fizeram um acordo com a Tupi de São Paulo. A estação paulista produziu e exibiu a novela em São Paulo, e a transmissão carioca ficou com a TV Rio. Ambas se tornaram líderes de audiência. Em 13 agosto de 1965, o encerramento do drama televisivo se deu de forma sem precedentes, com o elenco desfilando em carro aberto do centro de São Paulo até o ginásio do Ibirapuera, de onde o último capítulo foi apresentado ao vivo. No dia seguinte, a festa foi no Rio, com o Maracanãzinho abarrotado para a encenação. "O estádio superlotado dava uma mostra do poder das novelas sobre as massas. Numa espécie de neurose coletiva, o povo gritava o nome dos personagens e chorava". Posteriormente, festa semelhante aconteceria no estádio do Mineirão, em Belo Horizonte ${ }^{214}$.

$\mathrm{O}$ acordo entre emissoras diferentes para transmitir "O Direito de Nascer" era possível porque as TVs tinham ainda alcance local, com programações independentes e muito identificadas com a cidade de origem. Mas, naquele ano de 1965, uma nova emissora nascia e não demoraria a consolidar o formato de rede nacional -o que interessava, e muito, aos militares, que queriam uma unificação política do território. $\mathrm{O}$ aniversário do golpe foi em uma quinta-feira, dia $1^{\circ}$ de abril, e a inauguração da TV Globo estava marcada para a segunda seguinte, dia 5. Era a primeira televisão do País com um prédio exclusivamente construído para essa função, com três andares e cerca de 9 mil metros quadrados, no número 22 da rua Von Martius, no Jardim Botânico. O

\footnotetext{
213 Para as informações sobre a consolidação da telenovela e a estreia de Janete Clair em 1964, XEXÉO, Artur. Janete Clair: a usineira de sonhos. Rio de Janeiro: Relume, 2005, p. 59; a sinopse e o período de exibição de "O Acusador" estão em teledramaturgia.com.br.

214 Para a compra dos originais, OLIVEIRA SOBRINHO, José Bonifácio de. O livro do Boni. Rio de Janeiro: Casa da Palavra, 2011, p. 131-137; para a festa de encerramento, teledramaturgia.com.br.
} 
canal, cuja concessão havia sido dada a Roberto Marinho por Juscelino Kubitschek em 1957, começara a ser preparado três anos antes e, ao ser inaugurado, contava com 200 funcionários, parte deles vindos da Rádio Globo. Os equipamentos eram os mais modernos, importados graças a um acordo de financiamento firmado em 1962 com o grupo norte-americano Time-Life. Os profissionais brasileiros não tinham experiência com aquela tecnologia de ponta, o que fez com que a inauguração tivesse de ser adiada para 26 de abril ${ }^{215}$. Logo no primeiro dia, a Globo exibiu um seriado que pode ser considerado embrião de suas novelas. "Rua da Matriz", veiculado por dois meses, tinha entre os autores Moysés Weltman, o amigo de Dias Gomes, também do PCB.

Dois meses depois da inauguração da Globo, o acordo com a Time-Life virou polêmica nacional. Em 20 de junho, Lacerda fez um pronunciamento para acusar o contrato de ilegal, uma vez que a Constituição vetava a participação de capital estrangeiro em empresas de comunicação do País. Entre essa briga e a que compraria no mês seguinte, quando censurou “O Berço do Herói”, o governador, que também já fazia duras críticas ao regime militar que havia ajudado a colocar no poder, inspirou uma curiosa piada. Em 3 de julho, a coluna de turfe "O Cabresto", da "Folha de S.Paulo"216, zombou do governador se utilizando do grande sucesso do País no momento, a novela "O Direito de Nascer”: "Com base na oposição violenta ao namoro de Albertinho com a prima, uns e outros dizem que quem escreveu 'O Direito de Nascer' foi o Lacerda'. Na mesma coluna, um anúncio fictício brincava com o novo hábito de ver novelas: "Senhora fina, por motivos de viagem ao exterior, vende cadeira especial, tipo sanfona, própria para assistir a novelas emocionantes. Equipada com gavetas para lenços contra choro". Algumas páginas antes, a coluna "Política na Opinião Alheia"217, com frases pinceladas de diferentes jornais, mostrava a imprensa dividida em relação ao regime militar. O "Correio da Manhã" dizia que Lacerda estava aliado à "linha dura" para derrubar Castello Branco. "O Estado de São Paulo", que a "revolução afirma-se em cada dia que passa". A "Última Hora" denunciava que, "enquanto o governo fala em inimigos, os adversários declarados do regime de liberdade são os homens da linha

\footnotetext{
215 Informações sobre o adiamento da inauguração são do engenheiro Herbert Fiuza, da equipe que instalou a TV Globo, em vídeo do projeto Memória, da Globo (http://globotv.globo.com/redeglobo/memoria-globo/v/webdoc-cronologia-inauguracao-da-globo-1965/2580478/; acesso em 29/6/2016). 216 KHAN, Ali. O Cabresto. Folha de S.Paulo, 3/7/1965, p. 9

217 Política na opinião alheia. Folha de S.Paulo, 3/7/1965, p. 4 [matéria não assinada]
} 
dura". O "Diário de Notícias" comemorava a recuperação da economia, ao mesmo tempo que, para a "A Tribuna da Imprensa", o País estava "imobilizado e estagnado".

A liberdade na imprensa, em oposição ao rigor censório que Dias Gomes enfrentava com "O Berço do Herói”, se explica porque os quatro primeiros anos do regime, até a decretação do A1-5, são marcados pela "coexistência de práticas autoritárias com algumas liberdades individuais", com a repressão cultural focada no teatro. Nessa fase, a censura estava sendo sistematizada, estruturada e centralizada na capital federal, transferida do Rio para Brasília havia cinco anos. E, embora já houvesse no Brasil censura prévia para teatro, cinema, rádio e televisão, ela só seria estendida à imprensa depois de 1968, ainda de maneira informal, e legalmente com a publicação do decreto-lei $\mathrm{n}^{\mathrm{o}} 1.077$, de 26 de janeiro de $1970^{218}$. Na fase pré-AI-5, "vivia-se uma ditadura suficientemente forte para reprimir os movimentos sociais e políticos, mas taticamente moderada para permitir que a esquerda derrotada na política parecesse triunfar na cultura, o que alimentou o mito da "ditabranda".

Episódio envolvendo "O Direito de Nascer" evidencia que nem nesse período a ditadura foi "branda", e que a censura já mostrava seu lado violento, desmantelador e multifacetado ${ }^{219}$. Ainda não centralizada no governo federal, nem sempre se preocupava com os limites legais, apesar da busca dos militares por criar aparato jurídico para tentar justificar atos arbitrário, e agregava entre suas armas a pressão econômica, a tortura psicológica e a chantagem. "O Direito de Nascer" já havia sido mudada das 20h30 para as $21 \mathrm{~h} 30$, por determinação do Juizado de Menores do Rio (porque Soror Helena era mãe solteira do protagonista Albertinho Limonta, "um mal exemplo"), quando a Censura de Lacerda ameaçou exigir que seu horário passasse para 23h30. A alteração não só inviabilizaria a própria novela, como representaria a rúna da emissora, que se encontrava em dificuldades financeiras e tinha em "O Direito de Nascer" praticamente o único alicerce.

Walter Clark marcou um encontro com o secretário de segurança, Gustavo Borges, o mesmo que em julho assinaria o despacho com as razões da proibição da peça “O Berço do Herói”. De acordo com o diretor da TV Rio, ele exigiu que Carlos Heitor

\footnotetext{
218 Ver KUSHNIR, Beatriz. Cães de Guarda - Jornalistas e censores do AI-5 à Constituição de 1988. São Paulo: Boitempo, 2004, p. 42; e STEPHANOU, Alexandre. Censura no regime militar e militarização das artes. Porto Alegre: Edipucrs, 2001, p. 14. 219 Os adjetivos atribuídos à censura no período são de STEPHANOU, Alexandre. Censura no regime militar e militarização das artes. Porto Alegre: Edipucrs, 2001, p. 14.
} 
Cony, que publicava crônicas contrárias ao governo no "Correio da Manhã", deixasse a emissora, onde escrevia uma comédia de costumes. Também queria a saída de Roberto Campos, que não era contrário ao governo, mas crítico a Lacerda. Rindo, o secretário respondeu assim aos apelos de Clark para não alterar o horário da novela: "Você quer resolver o problema, meu filho? Então você tira de lá o Cony, e eu revejo a decisão de 'O Direito de Nascer'”. O diretor concordou, mas na saída teve que ouvir outra: "Tem mais. Aqueles escrotos da turma do Roberto Campos eu também quero que saiam". Clark tirou o Cony, raciocinando que "eram tempos de macarthismo tupiniquim, e eles tinham a força para caçar comunistas que quisessem". E concluindo que, "como os caras não podiam foder o Cony no 'Correio da Manhã' sem agredir a liberdade de imprensa, decidiram pegá-lo na TV”. Campos pôde continuar, provavelmente por "ordem de Brasília"220, o que evidencia a aflitiva situação de ordens, contraordens e critérios confusos -ou da falta completa de parâmetros.

$*$

Com a suspensão das eleições presidenciais do final de 1965, a ditadura deixava claro que viera para ficar, e 1966 começava sem ilusões para o País. O clima político era dos piores quando, na madrugada de 10 de janeiro, teve início um temporal com estragos sem precedentes no Rio de Janeiro, que durou cinco dias e devastou a cidade e os arredores, deixando 200 mortos e 50 mil desabrigados. Considerada a mais grave da história na região, a enchente demarcou o momento de virada da Globo, de uma jovem TV de pouco mais de oito meses para a emissora que conquistou corações e mentes dos cariocas -o que logo faria com o restante do País.

Walter Clark, que começara a carreira na TV Rio aos 20 anos e aos 24 havia se tornado seu diretor comercial, tinha sido contratado por Roberto Marinho no final de 1965 para tentar alavancar a audiência e o faturamento da Globo, que patinavam. A programação era muito elitizada, com concertos para a juventude e até cursos de inglês. Com o apoio de Moysés Weltman, o amigo de Dias Gomes autor da clássica radionovela "Jerônimo, o Herói do Sertão"221, e de outros pioneiros do canal, Clark

\footnotetext{
220 A his tória da censura a "O Direito de Nascer” está em CLARK, Walter, com PRIOLLI, Gabriel. O campeão de audiência - uma autobiografia. São Paulo: Editora Best Seller, 1991, p. 148-151. 221 Veltman, Henrique. Do Beco da Mãe a Santa Teresa. São Paulo: H. Veltman, 2010, p. 58
} 
repensou a programação às pressas, em dezembro, para reestreá-la na entrada de 1966, sob o slogan Ano Novo, Ano Globo. A nova grade começou relativamente bem, mas "ainda faltava um grande lance, algum evento que cristalizasse a imagem da emissora no conceito do público e que criasse uma aura de simpatia". E o grande lance seria a decisão do novato diretor de colocar as câmeras na marquise do prédio da emissora durante a enchente, de onde mostraram as ruas virando rios, casas desabando e pessoas ilhadas. A programação normal foi interrompida por três dia para dar lugar à transmissão da tragédia. Uma campanha, batizada S.O.S Globo, arrecadou roupas, remédios e mantimentos as vítimas. "Daí em diante, a Globo passou a ser amada pelos cariocas" 222 .

Estava mais do que na hora de a esquerda fazer um debate mais profundo sobre a sua relação com a televisão. Dois meses após a enchente, em março, a "Revista Civilização Brasileira" publicou o artigo "Problemas estéticos na sociedade de massas". Espécie de manifesto sobre o papel da arte na indústria cultural, era assinado por Ferreira Gullar, um dos principais pensadores do PCB, muito próximo de Dias Gomes, de quem esteve ao lado em várias discussões sobre esse tema. No artigo, Gullar "percebe a irreversibilidade da cultura de massa e não teme a 'realidade produtiva da idade industrial"”. Para ele, "a arte não deve abrir mão da sofisticação estética, mas precisa assumir negociações necessárias para atingir e conscientizar politicamente um grande público". Especificamente sobre a televisão:

Reconhece um conteúdo predominantemente conservador: ali, a alienação funcionaria a partir de um duplo mecanismo de mitificação, o de mostrar um real inacessível, de beleza plastificada nos "seres que parecem viver uma vida de sonho", e o de ocultar um outro real, "a fome, a miséria, a injustiça, a exploração e sobretudo as verdadeiras causas desses fatos”. No entanto, mesmo diante disso, Gullar acreditava, naquele momento, em uma positividade que estaria presente na essência da televisão. Para ele, haveria nessa mídia uma natureza de fundo democratizante, revelada pela exigência interna das emis soras em aglutinar na sua grade de programação elementos variados -“díspares pornatureza, estilo, gênero e situação his tórica”-, que

222 Sobre a enchente, ver CLARK, Walter, com PRIOLLI, Gabriel. O campeão de audiência - uma autobiografia. São Paulo: Editora Best Seller, 1991, p. 174-177. 
multiplicados e postos em choque poderiam "contribuir para formar, no espectador, uma complexa visão de seu próprio mundo.223

$\mathrm{O}$ artigo, conforme apontou o pesquisador Reinaldo Cardenuto, era "sintoma de um tendência entre artistas e intelectuais do PCB: a de tentar infiltrar-se criticamente na indústria cultural em formação, acreditando poder atuar dentro das restrições próprias aos meios de comunicação em massa". Era a "teoria da brecha". A discussão era nova, mas a presença de comunistas na televisão não. Grande parte dos profissionais pioneiros da TV vinham do rádio, que, como vimos, empregava diversos membros do Partido. Da mesma forma que acontecia com as rádios, as estações de TV logo teriam roteiros e programas criados por profissionais do teatro de esquerda. O "Teatro dos Nove", por exemplo, surgiu do Teatro Arena, como relata Álvaro de Moya, um dos fundadores da Excelsior, do qual se tornou diretor. Em 1961, um ano após a inauguração da emissora, Moya teve a ideia de criar um programa só com textos nacionais. Para a estreia, a peça escolhida foi "Eles Não Usam Black-Tie", de Guarnieri, o que fez com que o diretor, apesar da fase democrática do Brasil, tivesse de driblar um censor para colocar o espetáculo no $\operatorname{ar}^{224}$.

Dias Gomes seria um dos esquerdistas a realizar trabalhos esporádicos para a televisão em seu início, atividade que começou quando ele entrou para a lista negra dos autores, após a demissão da Rádio Clube, em 1953. Menos visada que o rádio no momento, a TV Tupi comprou seus textos escritos sob pseudônimo, até que Sangirard Jr., simpatizante dos comunistas e diretor da agência Standard Propaganda, que produzia para a televisão, resolveu finalmente colocar o nome do dramaturgo nos créditos de seu roteiro para o "Teatrinho Kibon", da Tupi. Nessa ocasião, Dias chegou a ser contratado pela agência para fazer teleteatros semanais. Como conta no diário, suas razões eram financeiras, e ele ainda não via um caminho artístico ou revolucionário no novo veículo. Para o dramaturgo, até ali, o dilema entre a qualidade artística, "a arte

\footnotetext{
${ }^{223}$ CARDENUTO, Reinaldo. A sobrevida da dramaturgia comunista na televisão dos anos de $1970-\mathrm{O}$ percurso de um realismo crítico em negociação. In: NAPOLITANO, Marcos; CZAJKA, Rodrigo; MOTTA, Rodrigo Patto Sá. Comunistas Brasileiros - Cultura política e produção cultural. Belo Horizonte: Editora UFMG, 2013, p. 88. No artigo de Cardenuto, ele diz que o texto foi publicado em 1965, mas o ano, na verdade, foi 1966. Em 1965, Gullar havia iniciado essa discussão como artigo "A cultura posta em questão", também na "Revista da Civilização Brasileira".

${ }^{224}$ MOYA, Álvaro de. Glória in Excelsior - Ascensão, apogeu e queda do maior sucessoda televisão brasileira. São Paulo: Imprensa Oficial, 2004, p. 49
} 
pela arte", e a necessidade de se falar para grandes plateias, "a arte engajada", se dava com o rádio.

Mesmo em 1966, apesar do crescimento da TV e da consolidação da Globo após a enchente do Rio, Dias estava focado no teatro, que se mantinha, para ele, como o veículo da revolução. Os profissionais do teatro, organizados em movimentos de crítica política desde o fim da década de 1950, seguiram combatentes no pós-1964 e, tanto que as peças se tornaram o primeiro foco dos militares, ainda que a censura se desse de forma errática. Apesar da proibição de “O Berço do Herói”, em 1965, Dias Gomes conseguiu levar aos palcos seu espetáculo seguinte. Em 23 de setembro de 1966, no Teatro Jovem e sob a direção de Ziembinski, estreou "O Santo Inquérito", uma inequívoca crítica à ditadura militar, que usava "a caçada dos hereges da Inquisição como uma forma de reflexão sobre a censura, a perseguição e a tortura" aos opositores do novo regime. Em uma entrevista para "O Jornal", em 12 de outubro, ao falar da peça, deixou claro o seu objetivo:

A época em que vivemos é de angústia, apreensões e até delações. Temo que os ódios ultrapassem as fórmulas da paz. Teríamos, então, o caos. Considero essencial a liberdade de qualquer ação para podermos debater, sempre, mesmo com rispidez, nossas ideias e pensamentos. ${ }^{225}$

Ainda que a crítica à ditadura pudesse ser encenada nos palcos e até comentada em jornais, a sombra da repressão seguia no encalço do autor. A própria montagem havia sido um sacrificio, uma vez que os patrocinadores, temerosos de uma nova proibição depois do que acontecera com “O Berço do Herói”, sumiram. Dias teve de correr atrás de financiamento alternativo, o que conseguiu com a ajuda do editor comunista Ênio Silveira, da Civilização Brasileira, que reuniu companheiros pecebistas para se quotizarem² ${ }^{26}$. A iniciativa expõe uma condição importante da época: se, por um lado, a militância oferecia riscos, por outro, organizava uma rede de proteção entre seus membros, em uma "relação intrincada com custos e beneficios".

225 As informações sobre "O Santo Inquérito" e esse trecho da entrevista de Dias Gomes estão em SACRAMENTO, Igor Pinto. Nos tempos de Dias Gomes - A Trajetória de um intelectual comunista nas tramas comunicacionais, doutorado na UFRJ, 2012, p. 222

226 GOMES, Dias. Apenas um subversivo. Rio de Janeiro: Bertrand Brasil, 1998, p. 225 
A militância comunista implicava riscos -como o de perseguição, de prisão e, em casos-limite, de morte-, além de exigir disciplina e obediência às ordens da direção do PCB na clandestinidade, sem contar o preconceito socialmente diss eminado contra o comunismo. Mas também oferecia uma rede de proteção e solidariedade entre os camaradas no Brasil e no exterior, o sentimento de pertencer a uma comunidade que se imaginava na vanguarda da revolução mundial e podia dar apoio e organização a artistas e intelectuais em luta por prestígio, poder, distinção e consagração em seu campos de atuação, para si e para o Partido. ${ }^{227}$

O raciocínio pode se aplicar melhor a artistas menos consolidados do que a Dias Gomes, nome de repercussão internacional. Mas vale lembrar que ele entrou no Partido quase duas décadas antes de se tornar bem sucedido na carreira, e que, menos do que uma questão pragmática, o engajamento de artistas e intelectuais ao PCB, "além das razões políticas mais abrangentes", passava pela procura de "legitimidade", para "marcar posição e ganhar (ou evitar perder) prestígio em suas atividades, lutando por um lugar de destaque e -no limite- pela hegemonia em cada campo, não só de seu grupo, mas também das ideias comunistas" ${ }^{228}$.

Mas o preço a se pagar pela militância política ficava cada vez mais alto, e é daquele ano de 1966 o primeiro registro de fichamento de Dias Gomes pelo Serviço Nacional de Informações. Em 13 de abril, dois meses antes de o SNI completar dois anos de existência, o autor foi incluído em uma "relação de brasileiros integrantes de diretorias de entidades que possuem intercâmbio cultural com os seguintes países comunistas: URSS, China e Cuba"229 - constava como presidente do Instituto de Intercâmbio Cultural Brasil-URSS. O órgão de inteligência do governo, que tinha o papel de vigiar opositores, logo se debruçou sobre as atividades cultura is de esquerda. $\mathrm{O}$ calhamaço que Dias Gomes acumulou ao longo de toda a existência do SNI tem 432 páginas, sendo 94 documentos, a maior parte delas com carimbos de "confidencial", "sigiloso" e algumas com o de "urgente". O último registro foi feito a apenas dois meses da assinatura da lei que extinguiu o órgão, assinada por Fernando Collor em 12 de abril de 1990 -em 13 de fevereiro o SNI registrou uma viagem de Dias Gomes ao exterior,

\footnotetext{
227 RIDENTI, Marcelo. Brasilidade revolucionária. São Paulo: Editora Unesp, 2010, p. 12

228 Ibidem para a ponderação sobre perdas e ganhos dos artistas comunistas.

${ }^{229}$ Informação n ${ }^{\circ}$ 303/SNI/ARJ, SS16-107, 13/4/1966
} 
em uma lista de brasileiros "com antecedentes negativos" que estavam embarcando para outros países: o autor havia ido em 21 de outubro de 1989 para... os Estados Unidos ${ }^{230}$.

Sem ter conhecimento desse grau de monitoramento de suas atividades e animado com a aprovação de "O Santo Inquérito" pela Censura, Dias acreditou haver um outro caminho para “O Berço do Herói’. Nesse ano de 1966, vendeu os direitos da peça a Herbert Richers, para a produção de um filme. Por precaução, antes das filmagens, o produtor enviou a Brasília o roteiro, escrito pelo dramaturgo. Mas o general Riograndino Kruel, superintendente da Polícia Federal e cujo irmão, Amauri Kruel, havia integrado a FEB nas batalhas da $2^{\mathrm{a}}$ Guerra, assim como o falso herói da peça, respondeu com um recado: "Diga ao Dias Gomes que pode tirar o cavalinho da chuva porque, enquanto nós estivermos no poder, essa peça não será encenada nem filmada". 231

Com uma obra liberada e outra proibida, o autor tentava entender o que podia e o que não podia naquele Brasil confuso. E realmente não era uma tarefa fácil. Em 22 de agosto, relatório da CPI da Câmara sobre o caso Globo - Time Life, considerou o acordo inconstitucional, pois a empresa norte-americana estaria participando da organização intelectual e administrativa da emissora. Seis meses depois, em 28 de fevereiro de 1967, Castello Branco assinou uma lei com modificações ao Código Brasileiro de Telecomunicações, que, apesar de manter o veto à participação de estrangeiros em empresas de radiodifusão, não tinha efeito retroativo e, portanto, isentava a Globo dos acordos assinados anteriormente. Para não sobrar dúvidas, em outubro, o consultor-geral da República, Adroaldo Mesquita da Costa, emitiu parecer considerando não haver sociedade das empresas e, assim, legalizando oficialmente a situação da TV Globo ${ }^{232}$.

Se facilitava com um caneta, o governo complicava com outra. Uma portaria de maio desse mesmo ano estabeleceu a censura prévia de filmes, programas de rádio e TV,

\footnotetext{
${ }^{230}$ Cópias dos documentos foram obtidas para esta pesquisa através da autorização da viúva do autor, Bernadeth Lyzio, uma vez que a emissão, pelo Arquivo Nacional, só pode ser liberada por familiares; o documento sobre a viagem citado: Ministério da Aeronáutica, Secretaria de Inteligência da Aeronáutica, Informe $n^{\circ}$ 023/90/22/A GINT-RJ, 13/2/1990

231 A história da censura ao filme está em GOMES, Dias. Apenas um subversivo. Rio de Janeiro: Bertrand Brasil, 1998, p. 223.

${ }^{232}$ Informações sobre a lei e o parecer que legalizaram a situação da Globo estão no site do projeto Memória da emissora (memoriaglobo.globo.com).
} 
novelas, músicas, peças de teatro e de toda manifestação artística ${ }^{233}$. Ficava cada vez mais dificil entender o que podia e o que não podia. E ia piorar muito.

${ }^{233}$ A informação sobre a portaria está em KUSHNIR, Beatriz. Cães de Guarda - Jornalistas e censores do AI-5 à Constituição de 1988. São Paulo: Boitempo, 2004, p. 116. 


\subsection{Capítulo 5}

\section{A gente se vê na Globo}

"O ano que não terminou" começou de forma trágica para a família Dias Gomes. Em 21 de janeiro de 1968, o garoto Alfredo, filho do casal, então com oito anos, viu uma mariposa preta no sobrado da família. Um amiguinho havia the dito que isso era sinal de morte próxima ${ }^{234}$. Nesse dia, Marcos Plínio, o caçula, com dois anos e meio, sentiu-se mal, e foi levado para o hospital. Morreu subitamente de parada cardíaca, o que fez Dias Gomes dar um murro na parede da UTI e Janete Clair teve de ser dopada. O casal foi passar uma temporada na casa de praia de um amigo, no Recreio dos Bandeirantes, mas o isolamento só aumentou a dor, e os dois voltaram para o sobrado da família. Janete, que já estava na Globo, resolveu então se exilar em seu mundo fictício, que a realidade estava insuportável, e escreveu uma novela atrás da outra. Foram sete seguidas, cinco anos sem férias ${ }^{235}$.

Dias também tentava refúgio no trabalho, mas para ele isso foi mais dificil. $\mathrm{O}$ clima era de terror, com centenas de peças censuras, entra elas montagens de "A Revolução dos Beatos" em diversos estados. Na Bahia, um grupo teatral conversou com um "coronel encarregado de dizer o que podia e o que não podia ser encenado". Um dos atores resolveu the perguntar: "O coronel não acha que desse modo os senhores vão terminar por acabar com o teatro?". A resposta foi transparente: "Mas é isso mesmo. Teatro é uma coisa que precisa acabar"236.

De fato, o teatro era, ao lado dos movimentos estudantis, grande foco de preocupação em 1968. Em 23 de fevereiro -mês em que a classe teatral havia realizado um concentração na porta do Teatro Municipal do Rio contra a censura-, documento confidencial elaborado pelo Dops e depois encaminhado ao SNI trata, simultaneamente, de "atividades subversivas no plano estudantil" e de "peças teatrais subversivas" 237 . Sob o intertítulo "clima de agitação", constata que "a propaganda que esses grupos [de

\footnotetext{
${ }^{234}$ Entrevista de Alfredo Dias Gomes, filho do dramaturgo, à autora em sua residência, no Rio, em $11 / 5 / 2011$.

${ }^{235}$ Dias Gomes fala da morte em sua autobiografia (p. 226), não menciona a data, mas apenas que foi em um domingo de 1968. O dia exato foi obtido em edição do "Correio da Manhã" de 23 de janeiro, que lamentou a morte e falou do enterro, ocorrido na véspera. O refúgio de Janete Clair no trabalho está em XEXÉO, Artur. Janete Clair: a usineira de sonhos. Rio de Janeiro: Relume, 2005, p. 81-82.

236 GOMES, Dias. Apenas um subversivo. Rio de Janeiro: Bertrand Brasil, 1998, p. 227

${ }^{237}$ Secretaria de Segurança Pública - Dops - Informe nº 21 - ACE 3853, em 1/3/1968
} 
estudantes e simpatizantes do movimento estudantil] alimenta [sic] identifica-se pelo ódio e intransigência contra uma classe legítima e necessária à boa ordem da sociedade, qual sejam as Forças Armadas, apresentadas como se não passasse [sic] de câncer nacional". O nome de Dias Gomes surge na parte que trata da peça "Auto dos 99\%”. A obra, explica a próprio relatório, havia sido criada pelo CPC, da UNE, e proibida em 1962 pelo governo. Apesar disso, "os estudantes utilizaram quatro atores do CPC, dentre eles Oduvaldo Vianna Filho, e a apresentaram. De acordo com o documento, o TAB (Teatro do Autor Brasileiro) pretendia realizar, em março, uma retrospectiva de peças do "ex-Centro Popular de Cultura" (o CPC havia sido extinto pela ditadura, por isso o "ex"), incluindo "Auto dos 99\%". O grupo teatral, de acordo com o Dops, era formado por Giannni Rato, Armando Costa, Oduvaldo Vianna Filho e Dias Gomes.

Essa foi uma breve incursão do dramaturgo em grupos de teatro, até porque o TAB, diante do clima do País, seria criado e encerrado no mesmo ano, em 1968. O Dops afirmava que seus formadores eram ex-integrantes do CPC, "que tinha por objetivo transmitir ao povo peças teatrais de rua, nas quais se mostravam as agruras existentes no Nordeste e nos demais estados". Dias Gomes, apesar de ter vários amigos no CPC, na verdade nunca integrou formalmente ao grupo, "por discordar fundamentalmente de sua visão", que, na opinião dele, privilegiava a política em detrimento à obra de arte. Para o dramaturgo, a "obra é tanto mais política quando mais artística ela for. Em primeiro lugar, você tem que fazer uma obra de arte. Se ela for válida como obra de arte, ela o será politicamente. Se não, não será nada"238. Além disso, tinha um espírito demasiadamente livre, que chamava de "rebelde", para conseguir se enquadrar em regras de grupos, além das já determinadas pelo próprio Partido Comunista.

Ao abordar problemas com o movimento estudantil, o documento do Dops cita a Frente de Estudante do Calabouço, formada por "elementos comensais do restaurante central dos estudantes". O Calabouço servia, desde o início dos anos 1950, refeições a baixo custo para estudante, e se tornara palco de reuniões e de manifestações políticas. Pouco mais de um mês após a elaboração desse relatório, seria o cenário do primeiro assassinato de um estudante pela ditadura militar. Em 28 de março, o secundarista paraense Edson Luís de Lima Souto, de apenas 18 anos, seria morto por policiais que

\footnotetext{
${ }^{238}$ Declarações que estão na íntegra da entrevista de Dias Gomes a Marcelo Ridenti, da qual o sociólogo utilizou trechos em RIDENTI, Marcelo. Em busca do povo brasileiro - artistas da revolução, do CPC à era da TV. Rio de Janeiro: Record, 2000.
} 
tentavam evitar uma passeata dos jovens contra o aumento do preço do restaurante, que, com o golpe, passara a ser administrado pelos militares. Era o banho de sangue que faltava para incendiar a oposição ao regime.

Diversas manifestações foram organizadas, sempre reprimidas com extrema violência, e uma sequência delas, ocorrida entre 19 e 21 de junho no Rio, foi chamada de Semana Sangrenta. A última teve 23 baleados, quatro mortos, dezenas de feridos e centenas de presos. O ápice seria a Passeata dos Cem Mil, na qual artistas, intelectuais, jornalistas e as mais diversas personalidades foram às ruas da capital carioca na companhia dos estudantes, tudo amplamente noticiado pelos meios de comunicação.

Em São Paulo, também nesse movimentado mês de junho, o Oficina publicava uma série de anúncios provocativos na "Folha de S.Paulo" para anunciar a $1^{\text {a }}$ Feira Paulista de Opinião, com frases como "Que pensa você do Brasil de hoje?" e "Ganhou mandado de segurança contra a censura" ${ }^{239}$. Dias Gomes havia sido convidado por José Celso Martinez Corrêa, criador do Oficina, a participar do festival, para o qual elaborou "O Túnel”. Na história, havia um congestionamento absurdo, com todos entalados no trânsito desde 1964. Pouco adepto do teatro formalmente mais agressivo como o do Oficina, Dias se mostrava mais disposto a essas experimentações naquele momento, provavelmente em razão da radicalização do política do País. Mas sua incursão no teatro radical seria freada pela Censura, que vetou "O Túnel", assim como estava fazendo com outros textos do autor 240 .

Em desespero para conseguir levar algo aos palcos, pediu ajuda do ex-presidente João Goulart, exilado no Uruguai. Viajou para lá com o roteiro de 'Dr. Getúlio, sua Vida e sua Glória”, escrito com Ferreira Gullar, preso ao corpo com esparadrapo, temendo a fiscalização da alfândega. O presidente deposto gostou e concordou em dar algum dinheiro. Mas não foi muito. Apenas pagou a estadia da equipe em Porto Alegre, onde o espetáculo estreou em 10 de agosto, levado pelo Oficina -depois seguiria em temporada para o teatro João Caetano, no Rio. O Oficina havia sido fundado em 1964, com artistas ligados ao CPC, posto na ilegalidade com o golpe, e essa seria a primeira vez que uma companhia política encenava um texto de Dias Gomes. Trata-se da história de uma

\footnotetext{
239 Versões originais consultadas no acervo do jornal.

${ }^{240}$ As informações sobre "O Túnel" estão em SACRAMENTO, Igor Pinto. Nos tempos de Dias Gomes A Trajetória de um intelectual comunista nas tramas comunicacionais, doutorado na UFRJ, 2012, p. 234; e na autobiografia, em que Dias Gomes diz ter preparado a peça para a Feira Brasileira de Opinião (p. 227). Pesquisa com outras fontes, inclusive jornais da época, dá conta de que se realizou nesse ano a Feira Paulista de Opinião. A versão nacional aconteceria em 1973.
} 
escola de samba cujo enredo do ano seria a vida de Vargas. Enquanto o drama do ditador é encenado na quadra da escola, seu presidente vive sob ameaça de perder o poder, conquistado no voto dos integrantes, para um bicheiro. A trama metalinguística em torno de Vargas, personagem com o qual os militares tinham uma relação ambígua, acabou passando pela Censura.

O espetáculo ainda estava em cartaz no Rio quando, em 13 de dezembro, após reunião no gabinete do presidente da República, Costa e Silva, o ministro do Trabalho, Jarbas Passarinho, disse "às favas" os "escrúpulos de consciência" antes de votar a favor do A1-5. O ato institucional fechava o Congresso, acabava com o habeas-corpus e dava ao presidente o poder de cassar mandatos e de suspender direitos políticos em caráter definitivo. Foi anunciado naquela noite na televisão, pelo ministro da Justiça, Gama Filho, e pelo locutor contratado pelo regime, Alberto Curi. Uma onda de cassações e prisões se anunciava, começando no mesmo dia com a detenção de JK. Dias Gomes resolveu se refugiar no apartamento de um amigo. Carlos Lacerda, que três anos antes defendera o País do autor "subversivo" ao censurar "O Berço do Herói”, foi encarcerado pelos militares no primeiro amanhecer pós A1-5. De certa forma, ficou mais fácil entender o que podia e o que não podia no Brasil: nada podia.

No mesmo dia em que assistiu ao anúncio do AI-5, o telespectador da Tupi acompanhou mais um capítulo da nova novela das oito da emissora. "Beto Rockfeller" estava no ar havia pouco mais de um mês, desde 4 de novembro. A partir do argumento de Cassiano Gabus Mendes e com roteiro de Bráulio Pedroso, tinha como protagonista um anti-herói. Charmoso, o rapaz trabalha como vendedor de sapatos e consegue subir na vida, frequentando as altas rodas paulistanas, às custas de muita malandragem, aplicando golpes dos mais diversos.

Se para a literatura, o cinema e o teatro, o anti-herói era um figura comum -Cabo Jorge, de "O Berço do Herói”, é um desertor, que abandona os campos de batalha e passa a viver em bordéis, e a peça tem como tema justamente o mito do falso heróipara a telenovela isso era novidade. Concebida a partir da experiência das radionovelas, até aquele momento a novela de TV tinha forte influência do estilo melodramático, especialmente do cubano, utilizando adaptações de textos estrangeiros, com mocinhos e 
mocinhas idealizados, diálogos empolados e ambientação distante da realidade brasileira -algumas, da linha "capa e espada", tinham príncipes e princesas. Em "Beto Rockfeller", a linguagem "era coloquial, repleta de gírias e de expressões populares".

Reproduzindo fatos e fofocas retiradas de notícias de revistas e jornais da época, o enredo procurava reproduzir o ritmo dos acontecimentos no interior da própria narrativa. A preocupação central de Bráulio Pedroso era trazer o cotidiano vivido para o vídeo, o que significava "escrever uma novela com uma proposta realista", trabalhando inclusive a representação dos atores o mais próximo possívelda realidade. ${ }^{241}$

Não foi uma quebra abrupta no estilo. Seguia uma sequência de experiências anteriores, testadas muitos anos antes inclusive em fotonovelas e radionovelas, que buscavam uma modernização do formato, o que, naquele momento, significava aproximá-las da realidade do telespectador ${ }^{242}$. Em 1965, a Tupi exibira "O Cara Suja", adaptação de Walter George Durst de original mexicano, que fez sucesso com um protagonista "feirante, um homem do povo". "Ninguém Crê em Mim", escrita pelo pecebista Lauro César Muniz para a Excelsior em 1966, contara a história de uma jovem à procura do assassino do pai, enredo então inusual e moderno. "Antônio Maria", que havia estreado em julho de 1968 e estava no ar quando "Beto Rockfeller" foi lançada, também testou um personagem principal "que tinha um pé na pobreza", com uma linguagem realista, em um processo de "aclimatação do melodrama ao Brasil"243. Mas, diante da força do protagonista malandro interpretado por Luiz Gustavo, "Beto Rockfeller" despertou os profissionais da TV para uma nova fase e, por isso, se tornou um marco.

Apesar de a novela da Tupi não ter sido um estrondo de audiência, seu avanço estilístico soou como alarme para a TV Globo. Desde o início de 1966, a produção de novelas era comandada na emissora por Glória Magadan. A cubana, que fazia novelas

${ }^{241}$ RAMOS, José Mário Ortiz; BORELLI, Silvia H. Simões. A telenovela diária. In: ORTIZ. Renato; BORELLI, Silvia Helena Simões; RA MOS, José Mário Ortiz. Telenovela - história e produção, $2^{\text {a }}$ edição. São Paulo: Editora Brasiliense, 1991, p. 78

242 Ibidem

${ }^{243}$ Ibidem para "aclimatação do melodrama ao Brasil", p. 74; os comentários anteriores sobre as anteces soras de "Beto Rockfeller" são de NEGRÃO, Walter. O processo de criação da telenovela. In: LOPES, Maria Immacolata Vassallo (org.). Telenovela - Internacionalização e Interculturalidade. São Paulo: Edições Loyola, 2004, p. 206. 
para a Colgate-Palmolive, levou para dentro da Globo "os seus anos de janela na produção dos mais lacrimogêneos melodramas que a América Latina já viu’. Ao contratá-la, Walter Clark sabia que "novela era o produto mais eficaz para fisgar os telespectadores e mantê-los fiéis à emissora" ${ }^{244}$. O monopólio de Magadan havia acabado em 1967, quando Boni, recém-contratado, levou Janete Clair para salvar uma novela, "Anastácia, a Mulher sem Destino", cuja trama estava também sem destino e ia muito mal de audiência -é um episódio famoso: Janete inventou um terremoto para matar quase todos os personagens, recomeçando com apenas quatro deles e um novo enredo.

Boni tinha clara a necessidade de se investir nas telenovelas, porque elas "têm um ingrediente fundamental: são um grande formador do hábito de ver televisão"245. Naqueles primeiros anos de Globo, Janete, apesar de já ter feito histórias mais próximas da realidade nacional em suas radionovelas, tinha de rezar a cartilha de Magadan, que acreditava no seguinte:

“A única função da novela é entreter. Porque se pensamos em fazer algo de caráter mais elevado corremos o risco de não ser entendidos, nem de atingirmos a grande massa. A telenovela é um produto a ser vendido comercialmente, como um geladeira, um tipo de tecido ou um par de sapatos. Não é literatura, nem subliteratura. É um produto industrial.”246

Impregnado da "brasilidade revolucionária", Dias Gomes não se conformava com o fato de a chefe de sua mulher não admitir "que se contasse uma história passada no Brasil, com temática e personagens brasileiros". Certa vez sugeriu a Janete: "Diga a essa senhora para realizar novelas passadas aqui no Brasil, tratando de nossa cultura e de nossos problemas". E a mulher the respondeu: "Ela disse que o Brasil não é um País romântico e que não se pode admitir uma novela com um galã com o nome de João da Silva. Ele tem que se chamar Albertinho Limonta ou Ricardo Montalbán"247.

\footnotetext{
244 CLARK, Walter, com PRIOLLI, Gabriel. O campeão de audiência - uma autobiografia. São Paulo: Editora Best Seller, 1991, p. 178

245 Depoimento a vídeo sobre a inauguração da Globo do projeto Memória (memoriaglobo.globo.com). 246 ORTIZ, Renato e RAMOS, José Mário Ortiz. A produção industrial e cultural da telenovela. In: ORTIZ. Renato; BORELLI, Silvia Helena Simões; RAMOS, José Mário Ortiz. Telenovela - his tória e produção, 2 $2^{\mathrm{a}}$ edição. São Paulo: Editora Brasiliense, 1991, p. 160

${ }^{247}$ MATTOS, David José Lessa (org.). Pioneiros do rádio e da TV no Brasil. São Paulo: Códex, 2004, p. 77
} 
Mas João da Silva logo se tornaria um nome ideal para mocinho da Globo. A emissora, que como todas as TVs nascera local, seria a primeira a se tornar uma rede nacional, com apoio do governo militar. Entre uma série de incentivos, em 28 de fevereiro de 1969, um decreto-lei assinado pelo presidente Costa e Silva isentava as TVs do pagamento de impostos na importação de equipamentos. Essa franquia, como conta Gaspari, "foi concedida ao mesmo tempo que se renovava o parque de telecomunicações do Páis".

Havia sido inaugurada a estação receptora de sinais de satélites de Itaboraí, e em fevereiro de 1970 o País praticamente interligava-se por um sistema de transmissão por micro-ondas. O benefício estava ao alcance de todas as emissoras, mas para a TV Globo, inaugurada em 1965, foi um duplo incentivo. Tecnicamente, significou um pulo-do-gato, pois permitiu que ela se modernizasse, transformando-se na primeira rede nacional de televisão. Financeiramente, além de reequipá-la ao dólar oficial, permitiu que a diferença cambial atenuas se o custo da liquidação de um contrato com o grupo americano Time-Life. ${ }^{248}$

Gaspari afirma que o governo abriu para os veículos de comunicação "as portas do céu e do inferno". No mesmo momento em que o ministro da Justiça "apedrejava" a mídia com o acirramento da censura e da perseguição aos profissionais inconvenientes ao governo, o da Fazenda afagava o setor, negociando isenções e financiamentos Enquanto "Correio da Manhã" e "Última Hora", por exemplo, viveram "o ocaso" em razão da repressão da ditadura, acontecia "a alvorada do que viria a ser o maior império de comunicações da história do Brasil: o Sistema Globo de Comunicação”.

Em 1969, seu proprietário, Roberto Marinho, ainda não era um dos homens mais ricos do mundo, com um fortuna avaliada, nos anos 90, em mais de 1 bilhão de dólares. Pelo contrário, a TV Globo estava amarrada a uma dívida de 3,75 milhões de dólares com o grupo americano Time Life (...) Com maneiras gentis e um senso de lealdade fora do comum na política brasileira, Roberto Marinho era um adversário feroz pela astúcia, um aliado insuperável pelo sentido de oportunidade. A ditadura trans formava-se num

248 GASPARI, Elio. A ditadura escancarada. São Paulo: Companhia das Letras, 2002, p. 215, citando entrevista com José Bonifácio de Oliveira Sobrinho e entrevista de Joe Wallach, diretor da TV Globo, à revista "Imprensa" de março de 1990, pp. 46-50. 
milagre, e a televisão em cores, em seu ícone. Em 1969, a Rede Globo era formada por três emissoras (Rio, São Paulo e Belo Horizonte). Em 1973 seriam 11.249

O cerceamento à cultura se armava com novas leis, e as redações de jornais viviam clima de terrorismo mesmo antes da aprovação, em 1970, da censura prévia à imprensa. Como diria o futuro ministro da Justiça Armando Falcão, em sua autobiografia, "suspensas as garantias constitucionais clássicas [a partir do AI-5], a censura política foi uma consequência lógica, imediata e inevitável”. Afinal, resumiu, "na guerra, como na guerra"250. Gaspari conta que "a mordaça imposta à imprensa a partir de 1968 era confusa, onipresente e errática."

Passada a blitz do A1-5, os censores foram dispensados, e a tesoura foi instrumentalizada através de sucessivos encontros de autoridades com proprietários de empresas jornalísticas. Criou-se, assim, uma rotina de comunicações entre a Censura e as empresas, quase sempre telefônica, informal 251 .

Em novembro de 1968, havia sido sistematizada juridicamente a repressão a obras cinematográficas e teatrais. Assim, "O Berço do Herói” foi só a primeira peça de Dias Gomes censurada no regime militar. Com o avanço da ditadura, praticamente toda a sua obra estaria vetada, inclusive o filme "O Pagador de Promessas", vencedor da Palma de Ouro de Cannes. O dramaturgo não desistia e, mais que isso, quando tudo parecia desmoronar, escreveu uma peça, "Amor em Campo Minado", que não só criticava a ditadura como questionava o papel do intelectual de esquerda. Provocou mais uma vez os donos do poder e, de quebra, irritou seus companheiros, que o acusaram de "dar armas ao inimigo".

O cerco se fechava. Quando escrevia as últimas cenas dessa peça, recebeu um convite para conversar com o Boni, da Globo. Estava sufocado do ponto de vista artístico e financeiro, com as despesas da família sendo pagas pela mulher. Preocupada com o marido por diferentes razões - a morte recente do filho, as dificuldades para

\footnotetext{
249 GASPARI, Elio. A ditadura escancarada. São Paulo: Companhia das Letras, 2002, p. 217

${ }^{250}$ FALCÃO, Armando. Tudo a declarar. São Paulo: Nova Fronteira, 1989, p. 371

251 GASPARI, Elio. A ditadura escancarada. São Paulo: Companhia das Letras, 2002, p. 215, p. 217 218.
} 
trabalhar, os riscos da militância- Janete exigiu que a Globo o contratasse, na lembrança do filho Alfredo, na época com nove anos. "Eu só continuo se vocês o contratarem", teria dito ${ }^{252}$. Boni conta que, desde que contratara Janete, pensava também em chamar Dias para escrever novelas, mas "tinha medo, vergonha, achava que iria ofendê-lo". Então perguntou para a autora o que ela pensava da ideia. "Liga para ele. Está muito mal de dinheiro. Não diga que eu falei, mas está mal, sempre me pergunta se você não falou dele", respondeu Janete. O diretor the explicou que tinha vergonha de procurá-lo, pois imaginava que ele considerava a telenovelas "um subgênero". "Não, ele precisa", explicou a mulher ${ }^{253}$.

Independentemente dos detalhes da contratação, o fato é que, naquele momento, e por diferentes razões, todos -comunistas, televisão e ditadores- queriam colocar o João da Silva nas novelas.

252 Entrevista de Alfredo Dias Gomes, filho do dramaturgo, à autora em sua residência, no Rio, em $11 / 5 / 2011$.

253 Entrevista de Boni à autora, no Rio, em 12/9/2011. 


\subsection{Capítulo 6}

\section{O meu, o seu, os nossos comunistas}

Se documentos do Serviço Nacional de Informações acusariam Dias Gomes de utilizar o codinome Vitório para suas atividades subversivas, na TV Globo ele estreou sob outra alcunha: Stela Calderón. Magadan havia sido demitida e deixara uma novela em fase de pré-produção. A emissora pediu para o dramaturgo roteirizá-la. "A Ponte dos Suspiros" se passa em Veneza, nos anos de 1500, e Dias, agoniado como o enredo "alienante", conseguiu o verdadeiro malabarismo de encaixar nele uma sutil crítica à deposição de João Goulart, aliviando sua consciência ${ }^{254}$. A novela foi ao ar de 6 de junho a 15 de novembro de 1969 . No dia $1^{\circ}$ de setembro, a Globo coroava sua capacidade de transmissão para todo o Brasil com o lançamento do "Jornal Nacional", grande projeto de integração nacional cujo lançamento era abençoado pelos militares. Não dava mais para perder tempo com princesas italianas nas telenovelas.

Dias pôde trocar Veneza pela Bahia em "Verão Vermelho", estreia de seu verdadeiro nome como autor de novelas, no ar a partir de 10 de janeiro de 1970 . Um pouco antes, em 10 de novembro de 1969, Janete havia lançado sua primeira novela pós-Magadan, que também apostava em diálogos coloquiais e cuja divulgação não deixava dúvidas sobre os novos rumos da Globo: 'Em 'Véu de Noiva' tudo acontece como na vida real. A novela-verdade" 255 . No mesmo ano, Jarbas Passarinho, o ministro do "às favas" os "escrúpulos de consciência", declarava ao "Jornal da Tarde" que "seria ideal existir uma cultura que se fundasse na 'crença da nacionalidade', e não uma cultura importada, uma "forma de colonialismo cultural'". Em coro, o chefe da Censura Federal dizia que "o objetivo do Estado era conseguir que somente o talento e a criatividade, sem apelações, deem Ibope nos programas de televisão brasileira". Assim como as TVs e o governo, o mercado publicitário percebia que as tramas nacionais haviam se transformado em bom negócio -um supervisor de mídia da ColgatePalmolive, que tanto tinha investido em novelas com roteiros estrangeiros, concluiu que

\footnotetext{
${ }^{254} \mathrm{O}$ codinome Vitório está em documentos do SNI levantados para essa pesquisa; a história da crítica à deposição de Goulart, em GOMES, Dias. Apenas um subversivo. Rio de Janeiro: Bertrand Brasil, 1998, p. 258 .

${ }^{255}$ Para a divulgação de "Véu de Noiva", SACRAMENTO, Igor Pinto. Nos tempos de Dias Gomes - A Trajetória de um intelectual comunista nas tramas comunicacionais, doutorado na UFRJ, 2012, p. 250.
} 
as adaptações acabavam se tornando mais caras e menos interessantes para o público do que os textos originais de autores nacionais ${ }^{256}$.

Assim, o respaldo da indústria cultural a uma programação ideal para o governo militar -"nacionalista" e "de qualidade"- abriu espaço para importantes nomes da arte de esquerda, calados pela censura no teatro e no cinema, ameaçado pelos Inquéritos Policial-Militares e, mais do que nunca, interessados em levar sua abordagem crítica da situação do País à grande plateia com a qual a TV contava.

O campo da televisão absorve escritores considerados mais eruditos, e passamos a nos defrontar com novelas de autores com experiência no teatro e no cinema. Este movimento, que já havíamos constatado no momento anterior, se cristaliza, particularmente porque os adaptadores de textos (Durst, Benedito Ruy Barbosa etc.) passamagora a escrever suas próprias novelas. ${ }^{257}$

Esse encontro aparentemente inusitado de interesses teve a Globo como seu principal palco -especialmente ao industrializar a produção de telenovelas-, e Dias Gomes talvez seja "o exemplo mais marcante dessa incorporação" da esquerda pela indústria cultura ${ }^{258}$, que se fortalecia durante a ditadura.

O grande sucesso da MPB no mercado fonográfico e da teledramaturgia feita por autores comunistas empregados pela Rede Globo são os exemplos mais paradoxais de uma linguagem artística tributária do nacional-popular triunfante na indústria cultural, ao mesmo tempo que vigiada pela censura estatal.

Uma boa parte dos dramaturgos ligados ao Partido Comunista Brasileiro (PCB), como Dias Gomes, Oduvaldo Vianna Filho e Paulo Pontes, contribuiu para diversificar o estilo, a temática, a linguagem das telenovelas, aprofundando a tendência "realis ta" e "sociológica" já anunciada por Beto Rockfeller, em 1968. ${ }^{259}$

\footnotetext{
${ }^{256}$ RAMOS, José Mário Ortiz; BORELLI, Silvia H. Simões. A telenovela diária. In: ORTIZ. Renato; BORELLI, Silvia Helena Simões; RA MOS, José Mário Ortiz. Telenovela - história e produção, $2^{\mathrm{a}}$ edição. São Paulo: Editora Brasiliense, 1991, p. 74

257 Ibidem, p. 93

258 Ibidem

${ }^{259}$ NAPOLITANO, Marcos. 1964 - His tória do regime militar brasileiro. São Paulo: Contexto, 2014, p. $176-177$
} 
O historiador Nahuel Ribke calcula que pelo menos 50\% das novelas exibidas pela Globo entre 1968 e 1979 sejam de dramaturgos teatrais críticos ao regime -foram 32 entre 67 títulos, sendo nove de Dias Gomes e sete de Lauro César Muniz, que também foi membro do $\mathrm{PCB}^{260}$.

Voltando ao princípio dos anos 70, sob o governo Medici, quando se consolidou o processo de modernização conservadora da sociedade brasileira, a atuação dos artistas de esquerda foi marcada por certa ambiguidade: por um lado, a presença castradora da censura e a constante repressão a quem ousava protestar, que implicou a prisão, o exílio e até a morte de alguns deles; por outro lado, cresceu e consolidou-se uma indústria cultural que deu emprego e bons contratos aos artistas, inclusive de esquerda, com o próprio Estado atuando como financiador de produções artísticas e criando leis protecionistas aos empreendimentos culturais nacionais. O governo e a mídia, especialmente a televisão, iam desfigurando as utopias libertárias, transformando-as em ideologias de consolidação da nova ordem nacional. A mistura de romantismo e realismo dos movimentos culturais revolucionários dos anos 60 banalizava-se, por exemplo, nas telenovelas. ${ }^{261}$

Como não poderia deixar de ser, o triângulo era frequentemente tenso. Afinal, se era consenso que o Brasil deveria ser abordado, o retrato do País obviamente era bem diferente na visão da esquerda e dos militares. E a indústria cultural, de certa forma, dependia dos dois lados. Lembra-nos Napolitano:

As alianças entre esses grupos também eram tensas, precárias e fluidas. Os empresários liberais da cultura aceitavam a arte de esquerda, mas impunham certos limites para não perder as benesses do Estado. O Estado autoritário de direita precisava de artistas de esquerda com trânsito na classe média, mas não podia aceitar a radicalização de suas posições (daí a contraditória política cultura do regime). A esquerda se debatia para afirmar qual o melhor caminho da crítica. ${ }^{262}$

\footnotetext{
${ }^{260}$ RIBKE, Nahuel. Telenovela writes under the military regime in Brazil: Beyond the cooption and resistance dichotomy. Media, Culture \& Society, 2011

${ }^{261}$ RIDENTI, Marcelo. Em busca do povo brasileiro - artistas da revolução, do CPC à era da TV. Rio de Janeiro: Record, 2000, p. 323

262 NAPOLITANO, Marcos. A "estranha derrota" - Os comunis tas e a resistência cultural ao regime militar (1964-1968). In: In: NAPOLITANO, Marcos; CZAJKA, Rodrigo; MOTTA, Rodrigo Patto Sá. Comunistas Brasileiros - Cultura política e produção cultural. Belo Horizonte: Editora UFMG, 2013, p. 327
} 
A própria intenção revolucionária dos autores tenderia a ser diluída por algo que Ridenti chama de "mercado de contestação". Pouco tranquila, a incorporação mercadológica da chamada "brasilidade revolucionária" faria que, com o tempo, viesse a deixar de ser "revolucionária" ainda que mantivesse a "brasilidade":

Os aspectos questionadores iam-se diluindo diante da poderosa indústria cultural que se firmava, até mesmo criando um lucrativo mercado de contes tação à ordem estabelecida.

Muitos dos cineastas, compositores da canção populares, atores, dramaturgos e outros artistas contestadores nos anos 1960 viriam a fazer sucesso, por exemplo, na maior instituição da indústria cultural brasileira atual: a Rede Globo de Televisão (...) que floresceu sob as asas da ditadura militar. ${ }^{263}$

Em meio a esse "triângulo amoroso" de alta voltagem, Dias Gomes seguiria sob forte vigilância dos militares. Em 19 de fevereiro de 1971, foi obrigado a depor no Cenimar (Centro de Informações da Marinha), conhecido pelas torturas e "desaparecimentos". Sabia que Walter Pontes, integrante do Comitê Cultural do qual fazia parte, havia sido preso e, sob tortura, entregara os companheiros. Naquele momento ia ao ar a sua segunda novela, "Assim na Terra como no Céu”, que tinha na trama um mistério sobre a morte de uma personagem, Nívea. No Cenimar, o encarregado do inquérito recebeu Dias falando sobre um pedido que o autor havia feito para que o depoimento fosse adiado -queria ganhar tempo para avisar o maior número de pessoas, dentro da Globo especialmente. O militar quebrou o clima de pânico do escritor dizendo: "Só adio com uma condição. O senhor vai me dizer quem matou a Nívea". Respirando aliviado, e irônico como sempre, o escritor respondeu: "Isso eu não confesso nem sob tortura".

Folclórica, a cena dá conta de como a consagração midiática, de certa forma, pode ter servido de escudo a Dias, que enfrentou sete IPMs, mas nunca foi preso -fato do qual zombou em seu livro de memórias: 'Uma falha em minha biografia que me envergonha, uma injusta lacuna, pois, por tudo que fiz, sem modéstia, eu acho que merecia uma honrosa cadeia”. Alfredo, filho do autor, lembra que o pai prestava

${ }^{263}$ RIDENTI, Marcelo. Brasilidade revolucionária. São Paulo: Editora Unesp, 2010, p. 143 
depoimentos todos os anos durante a ditadura, e que a Globo sempre dizia para avisá-la, pois, em caso de qualquer problema, "o doutor Roberto" seria acionado.

Outro episódio é revelador dessa condição da emissora como protetora de seus empregados "subversivos". Na noite da promulgação do A1-5, enquanto os militares prendiam JK e se preparavam para levar Lacerda à cadeia, a Globo livrava Walter Clark de ter o mesmo destino dos políticos "inimigos". Assim como Boni e outros diretores de TV, Clark flertara com o comunismo na juventude. A exemplo do que aconteceu com várias pessoas ligadas às artes -Dias Gomes, inclusive, como dissemos- tinha como missão arrecadar dinheiro para o Partido. Anos depois, em sua autobiografia (1991), se lembraria disso fazendo troça das "noites de discussões intensas sobre o futuro do Brasil proletário, tudo naqueles apartamentos luxuosos, ultraburgueses". Já afastado do PCB, mas com esse passado comprometedor, voltava para casa em 13 de dezembro de 1968, quando, por sorte, parou para tomar um chope e telefonou para a secretária a fim de saber os números do Ibope do dia. Ela the disse que mudasse de rota, pois na Globo haviam sido informados de que ele seria preso ao chegar em sua residência. A situação foi contornada por dois militares que a Globo havia contratado para fazer a ponte entre a emissora e o governo, Edgardo Manoel Erichsen e Paiva Chaves. Eles logo “ajeitaram as coisas"264. Sobre Erichsen, Boni foi direto:

Era um representante dos militares na TV Globo. Um agente duplo, servia aos interesses da TV Globo e dos militares. Foi indicado pelo próprio governo. Já que servia a dois senhores, tentava dourar a pílula dos dois lados. Às vezes trazia total irritação dos militares com a gente e às vezes conseguia liberar coisas nossas lá. Como a gente convivia com isso, quando ele trazia uma solução era festejado. Quando não trazia, era odiado. Situação extremamente esdrúxula ter um sujeito do outro lado mediando a seu favor. Era dificil. ${ }^{265}$

Além de salvar a pele de funcionários da emissora e de fazer o meio de campo com a censura, no auge da repressão aos movimentos armados de resistência, negociou diretamente com os militares a exibição de vídeos com depoimentos de militantes de

\footnotetext{
264 CLARK, Walter, com PRIOLLI, Gabriel. O campeão de audiência - uma autobiografia. São Paulo: Editora Best Seller, 1991, p. 199

265 Entrevista de Boni à autora, no Rio, em 12/9/2011.
} 
esquerda "arrependidos"266.

Clark, apesar de já não estar mais no Partido quando entrou na Globo, era um simpatizante, como boa parte dos dirigentes da televisão. Moya, da Excelsior, explica que a benevolência por parte dos executivos da TV -sem um engajamento direto- tinha dois aspectos significativos. O primeiro era que isso limitava a influência do PCB na programação. "Muitas vezes o Partido queria se meter nos roteiros, mas a TV não aceitava". O segundo tinha a ver com a estratégia para a proteção dos artistas. "Os comunistas nem queriam que a gente se envolvesse muito para não se queimar e seguir na direção dando abrigo a eles." ${ }^{267}$ Nesse contexto se dá a já anedótica história de que Roberto Marinho disse certa vez "Dos meus comunistas cuido eu"268. O jornalista Henrique Veltman lembra que o empresário se reuniu com a célula do PCB do jornal " $\mathrm{O}$ Globo", em sua sala, pouco antes do golpe. Falou que haveria mudanças no Brasil em breve e expôs um trato: "Se as coisas penderem mais para o lado de vocês, o que eu duvido, queria pedir para me contratarem para ser redator, não me deixarem fora desta casa. Mas, se penderem mais para o meu lado, podem ficar tranquilos, nada acontecerá com vocês" 269 .

Apesar dos "cuidados" de Roberto Marinho e da piadinha sobre a personagem que havia morrido na novela, Dias Gomes teve de carimbar os dez polegares na ficha policial e responder a uma série de perguntas. Acima das digitais, o papel trazia uma foto do autor com uma placa indicando a data, além de informações básicas, como nome, endereço, cor (branca), cabelos (castanhos), barba (raspadas) e bigode (sim). No depoimento, confirmou que em 1967 participara de um encontro de intelectuais a convite de Walter Pontes, mas que the disseram que não se tratava de reunião do Partido Comunista, e sim que tinha o propósito de apreciar teses a serem levadas ao VI Congresso do Partido Comunista Brasileiro. Falou ter sido transportado ao local de olhos vendados, para que não soubesse o endereço. Respondeu não se recordar de muitos participantes. Perguntaram-lhe sobre Ferreira Gullar (sempre chamado na documentação da inteligência de José Ribamar Ferreira) e outros artistas. Dias afirmou não se recordar. Quando the perguntaram se teria adotado o codinome Vitório, disse que

\footnotetext{
${ }^{266}$ KUSHNIR, Beatriz. Cães de Guarda - Jornalistas e censores do AI-5 à Constituição de 1988. São Paulo: Boitempo, 2004, p. 312

267 Entrevista de Álvaro Moya à autora, em São Paulo, em 19/8/2011.

268 Site do Projeto Memória da Globo; http://www.robertomarinho.com.br/mobile/obra/-dos-meuscomunistas-cuido-eu.htm (acesso em 14/5/2016)

269 Entrevista de Henrique Veltman à autora, em São Paulo, em 29/3/2011.
} 
não, até porque não era do Partido. Negou, negou, negou. E assinou afirmando ter dado as declarações de forma espontânea, sem qualquer coação física e moral.

O depoimento foi utilizado pela inteligência militar quando entrou em pauta o projeto do autor de escrever a novela "Marcado para Morrer". Em 28 de maio de 1971, reportagem publicada em "O Globo" sobre a obra seguiu, com suas declarações ao Cenimar, anexadas a um despacho encaminhado ao chefe do Cisa (Centro de Informações da Aeronáutica). O documento alerta para o fato de ele ser um "notório comunista indiciado em IPM", cuja nova novela tem como protagonista um "NAZISTA NEURÓTICO e dificilmente não será destinada a assemelhar o 'GOVERNO DA DITADURA BRASILEIRA' ao 'REGIME TOTALITÁRIO DA ALEMANHA NAZISTA', levando o público a identificar um-com-o-outro-e-vice-versa [as aspas, hifens e letras maiúsculas estão no original]."

Afirma ainda que o dramaturgo "é comunista ativo" e que "todas as suas peças são recheadas de temas a gosto das ideias marxistas. É voltado para a socialização do Brasil através da implantação do regime comunista". Lembra a famosa viagem a Moscou em 1953 e uma outra também suspeita, a Cuba, em 1968 (Dias menciona na autobiografia uma viagem à ilha comunista em 1963, para o lançamento do filme "O Pagador de Promessas", quando tomou um drinque com Raul Castro em seu apartamento, e outra, "anos depois", sem precisar a data, na qual conversou com Fidel por alguns minuto $\mathrm{s}^{270}$ ). $\mathrm{O}$ documento sugere que a novela "não venha a ser exibida em nenhum horário"271.

Por pressão do governo ou não, a Globo desistiu dessa trama, e o autor escreveu para o seu lugar "Bandeira 2", cujo protagonista é um simpático chefão do jogo do bicho, Tucão, interpretado por Paulo Gracindo. Foi a terceira novela de Dias Gomes, após "Verão Vermelho" e "Assim na Terra como no Céu" (ao final de "Bandeira 2", a Censura exigiria a morte de Tucão, uma vitória "do bem contra o mal", mas Dias driblaria essa intenção ao colocar um outro bicheiro segurando a alça do caixão, numa sugestão de que iria tomar o lugar do morto ${ }^{272}$ ).

Com a ampliação da teledramaturgia nacional, relatório do Cisa encaminhado ao SNI em 9 de junho tem como assunto algo que, àquela altura, se tornava uma das

\footnotetext{
270 GOMES, Dias. Apenas um subversivo. Rio de Janeiro: Bertrand Brasil, 1998, p. 189-191

271 Documentação encaminhada ao SNI, memorando $n^{\circ} 1336 / \mathrm{SI}$ - Gab, aviso $n^{\circ}$ 406/SI - Gab, de 5/7/1971, ao Ministério da Justiça.

272 A novela quase na maioridade. Veja, São Paulo, p. 80, 12/7/1972 [matéria não assinada]
} 
grandes preocupações do poder: "A infiltração comunista na TV". Ali, há o alerta de que as telenovelas, que se mostravam importante na estratégia de unificação nacional, passaram a revelar outra faceta, a de "imoral" e "subversiva"273.

O informe lista os problemas:

1. Ultimamente vem sendo levadas nas emissoras de TV algumas telenovelas de autoria de elementos ligados à ala intelectual das esquerdas brasileiras.

2. Essas peças trazem mensagens de desagregação de família, rebelião da juventude e espírito antirreligioso e principalmente apologia ao adultério. Algumas delas:

a. SIMPLESMENTE MARIA - faz apologia da mãe solteira [adaptação de Benedito Ruy Barbosa de original peruano, exibida na Tupi]

b. O CAFONA - procura mostrar a rebelião da juventude através do "happening" [autoria de Bráulio Pedroso, Globo]

c. IRMÃOS CORAGEM - mostra a imagem favorável ao adultério e a venalidade da lei [Janete Clair, Globo]

d. ASSIM NA TERRA COMO NO CÉU - caracteriza-se por uma posição antirreligiosa [Dias Gomes, Globo].

3. Todas essas telenovelas foram vetadas pela Censura Federal. Mais tarde forma liberadas para 18 anos.

4. A liberação nessa faixa de idade traz prejuízos aos patrocinadores porque elas não podem ser levadas ao vídeo antes das $22 \mathrm{~h}$.

5. Visando mudar essa faixa de idade, as empresas de TV procuraram usar todos os meios de pressão contra os órgãos da Censura. Algumas alcançaram sucesso, como "Os Irmãos Coragem", que saiu da faixa de 18 para 12 anos e está com uma audiência de 70\% (Ibope).

6. Atualmente a Censura Federal está analisando a peça [novela] "O HOMEM QUE DEVE MORRER", de autoria de JANETE CLAIR, esposa do novelista DIAS GOMES (esquerdista).

a. A estória é passada em Santa Catarina. Pela análise do "script", feita por este Centro, apresenta as seguintes mensagens:

1) Luta de classe numa região carbonífera.

2) Existência de preconceito racial, no sul do Brasil.

3) Desagregação da família, mostrada por várias cenas de adultério.

4) Apelo contrário à democratização de massa.

5) Antirreligiosidade de massa, no sentido de pôr em dúvida os princípios religiosos do cristianismo.

${ }^{273}$ Ministério da Aeronáutica, Gabinete do Ministro, Informação $n^{\circ}$ 040/Cisa - BR, 9/6/1971 
b. Como a peça deverá ser vetada [e aqui o texto datilografo é riscado e, por cima, à caneta, se anota "ainda será apreciada"] pela CENSURA FEDERAL, a revista "VEJA" (anexa) publicou uma notícia fazendo promoção favorável à peça.

c. Como a TV GLOBO já investiu cerca de $\mathrm{Cr} \$ 8.000 .000,00$ nesta telenovela, já foi sentida a presença de seus dirigentes a na área da POLÍCIA FEDERAL, no sentido de conseguirem a liberação da mesma. ${ }^{274}$

Além da preocupação do governo com as telenovelas, deve-se ressaltar a inclusão de Janete Clair na lista "problemática". Na época, a novelista, em razão da tradição mais romântica de suas histórias, era vista como "alienada", em oposição ao marido, "engajado", até porque nunca se filiou ao PCB. Essa imagem foi, de certa forma, cristalizada na memória nacional. Xexéo, na biografia da escritora, escreve que "os mesmos motivos que levaram o público a adorar as novelas de Janete Clair faziam os críticos rejeitá-la". "Doses exageradas de romantismo, nenhuma concessão ao realismo, excesso de escapismo. Não era o que a classe intelectual esperava de uma artista sob o tacão da ditadura". Reportagem publicada na "Veja" em fevereiro de 1971 -quatro meses antes da entrada do relatório no SNI, portanto- impunha a diferença entre o casal de autores. Sob o título "Novela a dois", revelava que ambos ganhavam o mesmo salário ("10.000 livres por mês"), desfrutavam de "idêntico sucesso", mas representavam "escolas opostas": "Janete não hesita em apelar para os dramalhões para prender a audiência, Dias Gomes tenta romper com isso, procurando fazer um crônica mais profunda da sociedade"275. Dois anos depois, em 1973, após conseguir 100\% de audiência em um capítulo de "Selva de Pedra", seria questionada, também pela "Veja", se não seria "muito cômodo poder falar para milhões de pessoas e só mostrar o lado positivo da vida". Considerou a acusação injusta ${ }^{276}$. Novamente, em 1974, quando ia ao ar sua trama "Fogo sobre Terra", enorme sucesso de audiência como sempre, seria novamente bombardeada pela crítica e responderia: "Tudo o que eu quero é contar uma boa história. De uma maneira simples, direta, popular. Minha responsabilidade, meu compromisso é com o grande público. Escrevo para milhões de espectadores. Não posso usar uma linguagem que faça o deleite de meia dúzia de intelectuais frustrados."277

\footnotetext{
274 Ibidem

275 Novela a dois. Veja, São Paulo, p. 58, 10/2/1971 [matéria não assinada]

${ }^{276}$ A arte popular das novelas. Veja, São Paulo, p. 3-5, 24/1/1972 [matéria não assinada]

277 XEXÉO, Artur. Janete Clair: a usineira de sonhos. Rio de Janeiro: Relume, 2005, p. 95
} 
A avaliação da inteligência do governo sobre a novelista era, obviamente, sigilosa, logo, ninguém poderia fazer ideia de que ela estivesse em listas de "subversivos". Em meio ao romantismo, a autora tratava, sim, de problemas nacionais "Irmãos Coragem", de 1970, o primeiro marco da teledramaturgia da Globo, falava de reforma agrária. Além disso, a Censura, que muito afetou suas obras, era discutida sob o ponto de vista da "moral e dos bons costumes", como era habitual, o que escondia seu fundamento político. Um dos intelectuais que tinham críticas ao estilo de Janete era Ferreira Gullar, o que a deixava magoada, pela proximidade do escritor com a família. Somente anos mais tarde, em 1978, o poeta comunista entenderia a lógica janetiana. Ele colaborava informalmente com Dias Gomes na novela "Sinal de Alerta", que tratava do problema da poluição ambiental. Os dois discutiam o destino de um personagem, "uma operária casada que, para a história ir em frente, teria que viver um caso de amor com um colega de fábrica”. Para Gullar, uma vez que a mulher era honestíssima, a traição não seria plausível. Janete observava a discussão e resolveu opinar: 'Não é plausível, mas ia ser lindo. Mandem o realismo à merda. Ela deve ter o caso e ficar grávida. $\mathrm{O}$ público ia adorar." Ideólogo dos mais importantes do PCB, Gullar finalmente cedeu: "Nós somos dois míseros realistas. Janete Clair é a verdadeira artista."278

O despacho do Cisa ao SNI também joga luz sobre a forma como a TV -e a Globo em especial- negociava com a ditadura a fim de evitar a censura nas novelas. Ribke atesta que o formato da telenovela, em capítulos, dificultava o trabalho dos censores, uma vez que se podia apresentar uma sinopse mais leve e, ao longo do caminho, subir o tom da crítica. Fora isso, a opinião de diferentes censores e dos variados níveis hierárquicos do governo, mais ou menos tolerantes, muitas vezes eram díspares. Essa característica, aliada ao poder industrial da telenovela, propiciava um ambiente de permanente tensão e negociação entre a Globo e a ditadura. Os autores e suas tramas eram consagrados pela audiência, e censurá-los drasticamente embutia um risco de desagradar a opinião pública ${ }^{279}$. Joe Wallach, que entrou na Globo como representante da Time-Life e permaneceu como diretor até 1980, abordou, em sua autobiografia (de 2011), essa negociação com o governo militar, citando a participação direta de Roberto Marinho:

\footnotetext{
278 Ibidem para a história de "Sinal de Alerta" (p. 91).

${ }^{279}$ RIBKE, Nahuel. Decoding television censorship during the last brazilian military regime - The censor as negotiator and censorship as a semi-open interpretative process. Media History, vol. 17, $\mathrm{n}$. 1. 2011
} 
As novelas passaram a ser severamente censuradas e sempre tínhamos que lutar para que elas fossem ao ar. Os militares desejavam cortar partes delas, de modo que a tensão sempre foi muito grande, por vezes causando grandes dificuldades. Roberto Marinho foi o grande líder nessa luta. 280

A conclusão do relatório do Cisa expõe os perigos, a partir da infiltração comunista na TV, que a telenovela, na visão da ditadura, passava a representar ao País:

A infiltração nos meios de divulgação vem aumentando de maneira gradativa e cada vez mais agressiva. A telenovela, que é atualmente o veículo de maior receptividade na massa, tem trazido mensagens de desagregação da família, rebelião da juventude e principalmente a apologia ao adultério. Os temas usados pelos autores esquerdistas visama atingir os objetivos comunistas a longo prazo. ${ }^{281}$

Se em 1971, Dias Gomes apareceu em três processos do SNI, em 1972 estaria em cinco. Em 11 de julho, relatório também do Cisa dava conta de que, a partir das várias prisões e apreensões de documentos efetuadas com o AI-5, foi possível constatar “o empenho do Partido em procurar por todos os meios recrutar (...) intelectuais com o objetivo de, através dos mesmos, aplicar o programa político marxista-leninista, visando a destruição do regime democrático brasileiro, para implementar um regime comunista." 282

Poucos dias depois, em 24 de julho, o SNI registrava cópia de relatório de IPM instaurado no $1^{\circ}$ Distrito Naval para apurar atividades do comitê cultural do $\mathrm{PCB}^{283}$. E então surgia documentada, pela primeira vez, a impressão do governo militar sobre "O Berço do Herói”, uma vez que, na ocasião da censura da peça, em 1965, os despachos haviam sido redigidos pelo governo Lacerda.

Alfredo Dias Gomes, apesarde alegar não ter participado de reuniões do Comitê Cultural do Partido, tem feito sub-repticiamente

\footnotetext{
280 WALLACH, Joe. Meu capítulo na TV Globo. Rio de Janeiro: Top Books, 2011, p. 57

${ }^{281}$ Ministério da Aeronáutica, Gabinete do Ministro, Informação $n^{\circ}$ 040/Cisa - BR, 9/6/1971

282 Centro de Informações da Aeronáutico, ACE A0477953, 11/7/1972

283 SNI, Agência Rio de Janeiro, Encaminhamento no 05119/72/ARJ/SNI, 24/7/1972
} 
campanhas contra o regime do País, com a publicação de obras literárias e dentre eles "Teatro de Dias Gomes", onde se pode observar a tentativa de levar à subversão e à destruição da imagem dos heróis brasileiros na tragédia “O Berço do Herói”. O livro com prefácio pelo Sr. Paulo Francis datado de 3 de novembro de 1964 foi editado em 1972, que lhe confere um caráter atual, possuiuma série de frases contrárias ao atual regime e comentários irônicos e até um reconhecimento de que a mesma é subversiva, logo no início pelo prefaciante.

O conteúdo não trazendo nenhum fundo moral procura infundir uma imagem deformadora da vida brasileira, vivendo do culto dos falsos heróis, numa cidade em que os incautos são explorados pelas pessoas mais representativas do local, tais como o prefeito, o padre e o major e até por um general do Exército Brasileiro, de outro local que procura encobrir a verdade, para ocultar erros anteriores. O progresso naquela obra é traduzido por criação de novos lupanares e cassinos.

A preocupação do autor em criar uma falsa imagem de heróis e militares é evidente. Na página 579 do Volume II de suas obras completas encontramos: "Branca deve ter morrido na cama, como os generais" e nas suas peças os heróis morrem em situações pouco compatíveis com o heroísmo. ${ }^{284}$

A análise conclui que "as novelas escritas pelo Sr. Alfredo Dias Gomes também traduzem o seu temperamento nitidamente subversivo e a participação deste escritor no Movimento Comunista Brasileiro". Curiosamente, "Irmãos Coragem" é tratada aqui como se tivesse sido escrita por ele, e não por Janete Clair:

A novela "Bandeira 2" critica as autoridades brasileiras, pois nela se observa o jogo clandestino exercido no Brasil e o governo constituído não impedindo que grupos contraventores se organizem para explorar esse tipo de comércio ilícito. "Irmãos Coragem” é uma demonstração, em forma de crítica, do latifundiário dos garimpos, principalmente na opressão aos garimpeiros com cobertura ostensiva de autoridades policiais. ${ }^{285}$

O tema da "infiltração comunista nos meios de comunicação" volta à baila em um relatório secreto do SNI de 15 de setembro ${ }^{286}$. Desta vez, a fim de concluir que o

\footnotetext{
284 Ibidem.

285 Ibidem

286 SNI, Agência Rio de Janeiro, Informação nº 11816/72/ARJ/SNI, 15/9/1972
} 
objetivo dos comunistas é tomar o poder nos órgãos de comunicação, o relatório é aberto com uma citação a Stalin: "A imprensa é o mais poderoso instrumento com o auxílio do qual o Partido, cotidianamente e a todo momento, fala com a classe trabalhadora na língua que the for necessária". Nas considerações iniciais, o SNI diz que a infiltração de comunistas nas áreas culturais havia diminuído desde a "revolução de 1964”, especialmente após a promulgação do AI-5. Com as punições impostas a partir do quinto ato institucional, "embora não tivesse ocorrido um saneamento total, constatou-se que os mais agressivos ou fugiram ou calaram-se e assim os órgãos de comunicação social passaram a viver em ambiente de relativa tranquilidade" -mas há a "presença de remanescentes, aliás em número bastante significativo". Admite o documento que a "Lei de Segurança Nacional e a Lei de Imprensa determinaram o estabelecimento de uma autocensura dentro dos órgãos de comunicação”. A prática, largamente disseminada, como pontua Kushnir, "preservava as empresas, mas também fazia delas colaboradoras de um esquema repressivo"287.

$\mathrm{Na}$ Globo, o advento da autocensura, que seria muito presente também nos telejornais, teve início com Dias Gomes, na narração de Walter Clark. Além dos já mencionados Edgardo Manoel Erichsen e Paiva Chaves, os "assessores militares" da emissora que haviam livrado o diretor da prisão na promulgação do AI-5, foi contratado José Leite Ottati, aquele censor "mais amável e compreensível" que fora, em 22 de julho de 1965, à porta do Teatro Princesa Isabel informar a Dias Gomes sobre a censura a "O Berço do Herói”. Aposentado da Censura estadual do Rio, virou censor interno da Globo. Segundo Clark, Dias era "impermeável a qualquer recomendação de prudência", e, em uma cena de "Bandeira 2", ele "exagerou", colocando a seguinte frase na boca do bicheiro Tucão, que citava o famoso colunista social de "O Globo": "Televisão tem que estatizar mesmo! Televisão que tem Ibrahim Sued no ar não merece moleza do governo!". Depois de enfrentar "um terremoto" na emissora, com a reação da direção ao "exagero" de Dias, Clark colocou o censor para ler tudo o que o dramaturgo escrevesse, "fazendo a censura mais rigorosa que fosse possível". Clark contou: "Daí pra frente, passei a jogar o jogo: o Dias escrevia o que queria e eu punha no ar o que podia. Não ia oferecer o meu pescoço em holocausto, para ele posar de campeão da liberdade (...) Preferia decidir o que ia ou não para o ar do que ouvir isso dos censores do regime."

\footnotetext{
${ }^{287}$ KUSHNIR, Beatriz. Cães de Guarda - Jornalis tas e censores do AI-5 à Constituição de 1988. São Paulo: Boitempo, 2004, p. 190
} 
Boni tem na lembrança que a contratação de Ottati havia ocorrido anteriormente, por indicação de Dercy Gonçalves, outra grande vítima da censura e de quem os militares chegaram a "sugerir" a demissão para a Globo. "Foi a Dercy que nos indicou o Ottati. Ela disse: 'O cara dá um jeito nas minhas peças para passar na Censura'. Ele penteava os textos e nos atrapalhou muito, porque tínhamos a Glória Magadan, que era muito conversadora. Os dois se juntavam, e estávamos perdidos." ${ }^{288}$ Do lado dos militares, acabou sendo considerado um traidor, conta Boni:

O Ottati era censor no tempo da censuras de costumes. Conhecia aquilo que ia pegar na Censura, "is so aqui passa, isso aqui não passa", porque os critérios eram absolutamente subjetivos. Estava lá para minimizar os problemas, não para corromper ninguém da Censura, mesmo porque, quando veio trabalhar para a gente passou a ser odiado do outro lado, ele mudou de lado. Ele lia uma novela e dizia: "Isso aqui não passa". Chamávamos is so de “pentear". Ele dizia: "Essa história passa se tirar essa palavra, trocar es se troço. Não fala "o cara se vingou", fala "o cara ficou com raiva". Ele tinha a cabeça do censor. ${ }^{289}$

Dias diria mais tarde que a censura interna chegava a ser pior do que a do governo. "Eu ia a Brasília, discutia com os censores, às vezes conseguia liberar alguma coisa. Mas contra a censura da empresa não se pode fazer nada." De qualquer forma, para uma ou para outra, acabou desenvolvendo uma técnica que atesta que o fato de ser "impermeável a qualquer recomendação de prudência" passava longe da falta de noção: "Você aprende a jogar com a censura. Muitas vezes, eu fiz cenas para serem cortadas, uma forma de entregar aquele boi de piranha. Você entrega um boi para passar o outro" 290 .

O SNI lista ainda "infiltrados" em redações de jornais e nomes do "setor dos chamados 'intelectuais'", entre eles Alex Viany, Vera Gertel, Luiz Jorge Werneck Vianna e Antonio Callado. Sobre Dias Gomes, repete as informações do documento do Cisa, das peças "O Berço do Herói” e "O Túnel".

\footnotetext{
288 Entrevista de Boni à autora, no Rio, em 12/9/2011.

289 Ibidem.

290 As declarações são de entrevista ao "Roda Viva" (TV Cultura) em 12/6/1995; disponível em http://www.rodaviva.fapesp.br/materia/405/entrevistados/dias gomes_1995.htm (acesso em 29/6/2016).
} 
É também mencionado o programa "Flávio Cavalcanti”, "em que nossos maiores compositores estão sendo expostos aos maiores ridículos perante milhões de telespectadores, sob a descortesia irreverente de um chamado 'júri jovem”". "A atuação desse júri vem oferecendo um espetáculo chocante junto ao público não só pelos insultos que dirige aos mais lídimos representantes de nossa música popular mas também porque promove um aguçamento no conflito de gerações", assinala o SNI. Essa passagem é simbólica de uma tendência na televisão da época: o cerco da Censura aos programas de auditório, que foram extremamente prejudicados, apesar de terem sido acusados de porta-vozes do governo na estratégia de "alienar as massas". Atrações comandadas por Flávio Cavalcanti, Dercy Gonçalves e Chacrinha, por exemplo, tinham bem menos poder de negociação do que as telenovelas em razão do formato, ao vivo e mais popular, além de uma participação inferior no faturamento das emissoras. Isso sem contar que, diante do governo, os apresentadores tinham menos prestígio do que os autores de novelas ${ }^{291}$.

Mais para frente, o documento do SNI menciona show no teatro João Caetano, com patrocínio do DCE da PUC, em que Gonzaguinha cantou músicas "pornográficas" como "Bota na Tua Bunda" e "Acuda Mãe, Acuda Pai, Acuda Gente". Vem em seguida uma descrição das atividades "subversivas" de Chico Buarque e Nara Leão. Ao final, na conclusão, lembra que, apesar desse "mar de subversão", ainda havia "heróis", como Nelson Rodrigues.

Do que foi exposto, conclui-se que o perigo da influência comunista sobre os meios de divulgação é latente (...) Em meio a tudo isso, há que se reconhecer o denodado es forço de determinados jornalistas que corajosamente abraçaram a causa democrática e procuram, apesardas violentas críticas dos seus opositores, veicular mens agens de otimismo, de esperança, de harmonia e de reconhecimento pelo esforço que o governo vem empreendendo no sentido de alcançar os seus objetivos estratégicos e cujos resultados já se fazem presentes. É um punhado de heróis em meio à

\footnotetext{
291 Para Cavalcanti e a censura a programas ao vivo ver RIBKE, Nahuel. The genre of live studio audience programmes in a political contexto: The Flávio Cavalcanti Show and de brazilian military regime. Screen, vol. 54, ed. 3, 2013; The brazilian military regime and television censorship: between the internal logics of production and the political context. Revista de História, n. 169, 2013; e OLIVEIRA, Lúcia Maciel Barbosa de. "Nossos comerciais, por favor!”: a televisão brasileira e a Escola Superior de Guerra: o caso Flávio Cavalcanti. São Paulo: Beca Produções Culturais, 2001.
} 
turbulência desse mar de subversão, e que estão a merecer o apoio das autoridades constituídas e o estímulo necessário para que continuem a utilizar as suas penas a serviço do Brasil, e entre os quais destacamos os nomes de Nelson Rodrigues, Gustavo Corção e Raul Giudicelli. ${ }^{292}$

$*$

Um dos principais representantes da imprensa alternativa, que ganhava força no auge da repressão com a tentativa de driblar a Censura oficial e a autocensura dos grandes veículos, o semanário "Opinião" publicou uma ousada entrevista de Dias Gomes em 4 de março de 1973 -que, logo nas primeiras linhas, lembra a censura a " $\mathrm{O}$ Berço do Herói”, acusada de ser um "ato ilegal do então governador Carlos Lacerda"293.

A reportagem registrava um momento crucial para o dramaturgo: se até ali sua carreira era marcada por peças teatrais, a partir daquele momento o seria pela criação da telenovela "O Bem-Amado", que, com o corrupto -e encantador- prefeito Odorico Paraguaçu e seus desmandos em Sucupira construía uma "alegoria do Brasil, mostrando a sobrevivência da tradição do autoritarismo e do coronelismo sob uma armadura modernizante" 294 . No ar havia pouco mais de um mês, a produção tinha por base peça homônima sobre a qual Dias falara no diário, no início da década de 1960. Era a primeira novela em cores da televisão brasileira e a mais cara já produzida no País ${ }^{295}$, cartão de visita do que seria chamado de "Padrão Globo de Qualidade". O selo envolvia apuro técnico mas também buscava excelência artística, o que levou a emissora a reforçar a contratação de profissionais ligados ao Cinema Novo, à MPB, ao CPC e a outros grupos de teatro engajado, além de dar cada vez menos espaço a programas de auditório e a tudo que pudesse ser considerado "popularesco". Se, por um lado, abria ainda mais as portas para a esquerda intelectual, por outro, o Padrão Globo se conectava

\footnotetext{
292 SNI, Agência Rio de Janeiro, Informação no 11816/72/ARJ/SNI, 15/9/1972

293 SILVA. Abel. Do Pagador de Promess as ao Bem-Amado. Opinião, 4/3/1973, p. 19

${ }^{294}$ A análise de "O Bem-Amado" como "alegoria do Brasil" está em SACRAMENTO, Igor Pinto. Nos tempos de Dias Gomes - A Trajetória de um intelectual comunista nas tramas comunicacionais, doutorado na UFRJ, 2012, p. 293-311.

295 Reportagem da Veja de 31/01/1973 afirma que o investimento inicial foi de 2 milhões de cruzeiros e a previsão era de 8 milhões no total.
} 
à imagem propagada pela ditadura do "Brasil grande", do "Ninguém segura este País"296 -eram tempos de convivência entre os Anos de Chumbo e o Milagre Brasileiro. "O Bem-Amado" também elevou a um novo patamar de prestígio o horário das $22 \mathrm{~h}$, reservado para as novelas de Dias Gomes -a faixa das 20h, de maior audiência, era de Janete Clair (com um tempo, foram contratados outros nomes para revezar com o casal, entre eles Bráulio Pedroso, Walter Negrão, Walter George Durst, Lauro César Muniz e Cassiano Gabus Mendes). Com menos cobrança em relação ao Ibope e, teoricamente, mais liberdade com a Censura por ser dirigido a um público mais velho, a faixa das $22 \mathrm{~h}$ era mais favorável a experimentações técnicas e temáticas, ideal para a brecha desejada por Dias para suas mensagens críticas.

A entrevista ao "Opinião", cuja manchete é 'Do 'Pagador de Promessas' ao "Bem-Amado", é exemplar do discurso adotado pelo autor comunista para justificar sua "polêmica" adesão, no dizer da reportagem, às telenovelas, principal fonte de lucro da emergente indústria cultural brasileira. Se até meados dos anos 1960, ele não via outro caminho para a sua arte política que não o dos palcos, a partir de sua entrada na Globo e do sucesso de suas novelas, a TV passou a ser defendida por ele como um poderoso meio de comunicação para atingir uma enorme plateia popular.

O autor afirma ter transferido o seu "laboratório de experiências, momentaneamente, para a televisão", apesar de acreditar que os meios de comunicação de massa divulguem "a cultura da classe dominante". Mas também assume que um dos motivos de ter deixado o teatro havia sido o "processo de intimidação e castração imposto à dramaturgia brasileira depois de 64". Apesar de ainda considerar o teatro como a "arte conscientizadora por excelência", admite que as telenovelas, dentro das limitações impostas, oferecem uma nova rota:

Claro que uma determinada telenovela, ou até mesmo a maioria das telenovelas, pode ter um efeito acomodatício, alienatório, anestesiante. Também uma peça de teatro (ou quem sabe a maioria das peças de teatro encenadas entre nós) pode ter o mesmo efeito, podendo-se estender a alegação ao cinema. Mas nem o cinema, nem o teatro, nem a novela, como formas de expressão, têm nada a ver com isso. E do mesmo modo que o

\footnotetext{
296 SACRAMENTO, Igor Pinto. Nos tempos de Dias Gomes -A Trajetória de um intelectual comunista nas tramas comunicacionais, doutorado na UFRJ, 2012, 293-311
} 
teatro pode ser um elemento conscientizador, também a novela pode desempenhar esse papel. Podemos levar esse objetivo às últimas consequências? Talvez não. Existem fatores limitativos, como censura e o caráter de grande indústria que cada vez mais assume a televisão. Mas o cinema também é uma indústria e também sofre censura. E no teatro a contradição básica arte-comércio é, queiramos ou não, um fator castrativo. Enfim, o artista, numa sociedade como a nossa, é sempre um homem ilhado. E em nossa pequena ilha temos que construir alguma coisa, sem cairmos na posição cômoda e suicida de cruzarmos os braços porque estamos cercados de água (ou de limitações) por todos os lados e ficarmos à espera do navio que virá nos salvar. ${ }^{297}$

O entrevistador, Abel Silva, volta a mencionar a censura a "O Berço do Herói”. Afirma que, na ocasião, Dias havia escrito em artigo que "jamais abriria mão de sua liberdade de expressão e que nenhum artista pode furtar-se a participar da luta contra a censura". E pergunta: "Como autor de telenovela, você ainda permanece fiel a esta posição de total independência quanto à censura?” Dias relativiza o significado de "independência". Diz que, no momento, todos são dependentes do sim ou não da Censura. E encerra com uma visão pragmática: "A independência, que consistiria em escrever peças para guardar na gaveta (como eu tenho algumas), na televisão seria quixotesca, destituída de qualquer sentido. Muitas vezes o fato de aceitarmos as regras do jogo não importa em abrir mão da liberdade de expressão, mas num desafio".

No encerramento da entrevista, o repórter pergunta se entre "O Pagador de Promessas" e "O Bem-Amado" o dramaturgo vê "continuidade, involução ou progresso". Na resposta, fica clara a estratégia do autor de "ajuste do seu passado para justificar a sua trajetória", que seria uma continuidade do seu projeto teatral, na qual ele "estabelece uma coerência entre o passado e o presente, afirmando que não importava tanto o meio ou instrumento de comunicação, mas a própria comunicação popular". Sempre, entretanto, ressaltando o tamanho da plateia da TV em comparação com a do teatro. E volta a usar o termo "quixotesco".

Acho que é uma evolução dentro do que me propus na TV: encontrar uma linguagem comum a uma plateia de milhões de pessoas, a mais heterogênea que já tive, composta de elementos de todas as classes sociais,

297 SILVA. Abel. Do Pagador de Promessas ao Bem-Amado. Opinião, 4/3/1973, p. 19 
do intelectual ao marginal. Faço parte de uma geração de dramaturgos que levantou entre os anos 50 e 60 a bandeira quixotesca de um teatro político e popular. Esse teatro esbarrou numa contradição básica: era um teatro dirigido a uma plateia popular, mas visto unicamente por uma plateia de elite. De repente, a televisão me ofereceu essa plateia popular. Recursar, virar as costas, seria incoerente, burro e reacionário. ${ }^{298}$

Esse sua nova argumentação soava como um rebate à ideia de que ele havia sido "cooptado" pela indústria. Reportagem da revista "Veja" sobre a estreia de "Assim na Terra como no Céu", em 1970, começava com a seguinte questão: "A telenovela mancha a carreira de um escritor ou dramaturgo?" e seguia com a "defesa do escritor": "A televisão é o mais poderoso veículo de divulgação de cultura de massa do nosso tempo."299 Dias costumava dizer que era estimulado pelas pessoas mais próximas, a quem respeitava, mas criticado por "intelectualóides, uns idiotas que achavam que estava cometendo uma traição, aderindo ao sistema, à alienação que era considerada a telenovela". Certa vez, foi hostilizado em um debate de estudantes, que fizeram uma peça em que um personagem dizia: "Dias Gomes, nós jamais o perdoaremos por isso"300. Em oposição, colocava-se como "infiltrado", apesar de ter consciência das contradições dessa opção.

O que a Globo me deu... A minha geração de dramaturgos nos anos 50, 60 sonhou com quê? Sonhou com um teatro político e popular. A geração Guarnieri, Vianinha, eu, Boal, era esse o nosso sonho. Nunca conseguimos fazer um teatro popular. Nunca conseguimos um teatro de plateia popular. Enquanto fazíamos no palco uma peça contra burguesia, na plateia estava sentada a própria burguesia. Era uma contradição que nunca conseguimos resolver. Para se fazer um teatro popular, era preciso mudar o regime, porque o regime é que impedia o teatro popular, desde que nos obrigava a cobrar um

\footnotetext{
298 Os trechos estão em SILVA, Abel. Do "Pagador de Promessas" ao "Bem-Amado". Opinião, São Paulo, pág. 19, 4/3/1073; para a adoção de um novo discurso por Dias Gomes, ver SACRAMENTO, Igor Pinto. Nos tempos de Dias Gomes - A Trajetória de um intelectual comunista nas tramas comunicacionais, doutorado na UFRJ, 2012, p. 264-276; e Idem. Por uma teledramaturgia engajada - A experiência de dramaturgos comunistas com a televisão dos anos 1970. In: NAPOLITANO, Marcos; CZAJKA, Rodrigo; MOTTA, Rodrigo Patto Sá. Comunistas Brasileiros - Cultura política e produção cultural. Belo Horizonte: Editora UFMG, 2013, p. 107-127.

299 O autor e o meio. Veja, São Paulo, pág. 73, 29/7/1970 [matéria não assinada]

300 As menções a críticas estão em entrevista do autor In: JÚNIOR, Gonçalo. Pais da TV. São Paulo: Conrad, 2001, p. 85.
} 
entrada que o povo não podia pagar, e o governo que deixava o povo em condições de não poder pagar essa entrada. Então era uma contradição insolúvel. Quando a Globo me chama, o que eu penso: Muito bem, a Globo estáme dando uma plateia popular, aquilo com que eu sonheino teatro o tempo todo, está me dando uma plateia que vai de A a Z. Vai desde de o intelectual até a cozinheira, faxineiro. Tenho o direito, quer dizer, politicamente está correto recusar? Não. É uma estupidez. "Ah bom, mas você está fazendo isso de dentro de um órgão que apoia o regime.” Mas e daí? Aquele espaço ali [da minha telenovela] é meu. Se depois daquilo, você tem algo de que discorda, tudo bem. Quando escrevo um livro, ele vai para uma livraria, exposto numa vitrine que tem de tudo. Tem obras do mesmo lado que são contrárias ao meu pensamento. E não quero dizer com isso que o sonho do teatro popular tenha se resolvido com a telenovela, de modo algum. Porque são cois as completamente diferentes, são gêneros diferentes. Mas em termos políticos foi resolvido, porque no Brasil, uma coisa intrigante, a telenovela -esse gênero folhetinesco considerado sub-literário, melodramático- se desenvolveu e se transformou no maior produto de consumo cultural. Nem o livro, nem o cinema, nada alcança o consumo da novela. Esteticamente, ele se desenvolve e acaba dando, ainda que prejudicado pelas limitações e pelas censuras de diversas naturezas, um retrato da vida brasileira. E se incorpora à cultura do País. ${ }^{301}$

Era uma postura em consonância com o Partido Comunista. Desde que os dogmas jdanovistas de realismo socialista foram substituídos, no fim dos anos 1950, pelo realismo crítico luckasiano, a esquerda incorporou a estratégia de "frentismo cultural" de Georg Luckás, como nos lembra Napolitano.

Com base no princípio frentista, os comunistas defendiam a ocupação de todos os espaços possíveis dentro do sistema, negociando até certo ponto o próprio conteúdo de suas ideias, materializadas em peças de teatro, filmes, canções e novelas. Ao longo dos anos de 1960 e 1970, os agentes culturais ligados ao Partidão foram fundamentais na consagração de um conteúdo peculiar da industrial cultural brasileira, sobretudo no cinema, na TV e na música popular, de ampla aceitação junto ao público consumidor da classe média. ${ }^{302}$

\footnotetext{
${ }^{301}$ Declaração retirada de íntegra de entrevista cujos trechos estão em RIDENTI, Marcelo. Em busca do povo brasileiro - artistas da revolução, do CPC à era da TV. Rio de Janeiro: Record, 2000. 302 NAPOLITANO, Marcos. A "estranha derrota" - Os comunistas e a resistência cultural ao regime militar (1964-1968). In: NAPOLITANO, Marcos; CZAJKA, Rodrigo; MOTTA, Rodrigo Patto Sá.
} 
"O Bem-Amado" seguiu com sucesso de público e crítica e sem incômodo da Censura por mais de cem capítulos. Mas, quando faltava menos de um terço para a novela acabar, a Divisão de Censura de Diversões Públicas decidiu emitir um parecer com os "problemas". Os pareceristas apontaram a "extrapolação" da "nuance puramente regional": "As situações afloradas, pelo seu duplo sentido, a essa altura dos acontecimentos, podem ser claramente interpretadas como alusivas à conjuntura nacional, particularizando instituições, pessoas ou mesmo outros valores consagrados". Dos 177 capítulos, 133 foram liberados sem alterações e 44 com cortes. Conforme aponta estudo de Rollemberg:

São, basicamente, de dois tipos. De um lado, visam a situação e termos que debocham de instituições e da autoridade constituída e apontavam os arbítrios do poder. Na mira de Dias Gomes, o prefeito, coronéis, o coronelismo, forças armadas, polícia, Igreja, latifúndio, propriedade. Na mira da Censura, a crítica do autor. O segundo tipo de corte refere-se à "moral e aos bons costumes", igualmente ironizados e desmoralizados, apontando a hipocrisia dos moralistas: casamento, adultério, família, virgindade, sexualidade, drogas. Adefesa da autoridade (traduzida por segurança nacional) e da "moral e bons costumes", os dois pilares do regime. Os dois alvos de Dias Gomes. Os dois alvos da Censura. ${ }^{303}$

Dentre os cortes que a Globo foi obrigada a fazer, ficaram famosos os dos termos “coronel”, usado para o prefeito Odorico, e "capitão", para o cangaceiro Zeca Diabo. A cinco capítulos do encerramento, o personagem cabo Ananias foi obrigado a perder a patente. Muitas vezes os episódios já estava gravados e editados, e o diretor, Paulo Ubiratan, era obrigado a cortar os filmes com gilete, perdendo cenas inteiras ${ }^{304}$. Dois meses antes de "O Bem-Amado" acabar, o nome de Dias Gomes voltara a desfilar no gabinete do SNI. O documento, de 15 de agosto de 1973, elencou o

Comunistas Brasileiros - Cultura política e produção cultural. Belo Horizonte: Editora UFMG, 2013, p. 329

303 ROLLEMBERG, Denise. O Bem-Amado e a Censura - Uma relação rigorosa ou flexível? In: NAPOLITANO, Marcos; CZAJKA, Rodrigo; MOTTA, Rodrigo Patto Sá. Comunistas Brasileiros Cultura política e produção cultural. Belo Horizonte: Editora UFMG, 2013, p. 75

${ }^{304} \mathrm{As}$ informações sobre a censura às patentes militares e à palavra "coronel" estão em GOMES, Dias. Apenas um subversivo. Rio de Janeiro: Bertrand Brasil, 1998, p. 276; para os cortes de Ubiratan, COURI, Norma. Playboy entrevista Dias Gomes. Playboy, São Paulo, p. 49-87, dez/1985. 
dramaturgo entre "elementos indiciados em inquéritos por subversão, assaltos, fugas de presídios e sequestro de avião". A novela terminou em 9 de outubro, mês em que o governo começou nova ofensiva contra a guerrilha do Araguaia - era o auge da repressão contra a luta armada. No dia 17 , Heitor Ferreira, secretário de Golbery do Couto e Silva e de Ernesto Geisel que circulou no centro do poder durante a ditadura, anotava em seu diário que Roberto Marinho, em conversa com Geisel, "queixara-se de humilhações, mas reconhecera que 'a censura está bem nessa questão de terrorismo'. Resumindo o que dele ouvira, o futuro presidente do País contaria depois: 'Aberturas etc., acha besteira. Liberdade, é essa aí mesmo. O importante é o Brasil tocar pra frente." $" 305$

Não muito tempo depois dessa conversa, o próprio Roberto Marinho iria censurar a obra seguinte de Dias Gomes, "O Espigão". A intensão da novela era criticar o crescimento desordenado das cidades, com o avanço dos arranha-céus, e outros efeitos desumanos do progresso -em alusão ao "milagre econômico" da ditadura. O vilão seria um empresário do ramo imobiliário. Ao saber da sinopse, Sérgio Dourado, proprietário de uma empresa do Rio que comprava casas para demolir e construir prédios altos (e um grande anunciante do jornal "O Globo"), telefonara para o dono da Globo, que, imediatamente, mandou cancelar a novela -em 1977, Dourado não conseguiria evitar a bem-humorada "Carta ao Tom", composta por Vinicius Morais e Toquinho, sátira a “Carta ao Tom 74", cujos versos diziam "Minha janela não passa de um quadrado / a gente só vê Sérgio Dourado / onde antes se via o Redentor”. A saída para a censura interna a "O Espigão" foi mudar o protagonista, de empresário do setor imobiliário para dono de uma cadeia hoteleira, que tentaria derrubar um tradicional casarão a fim de construir um prédio para abrigar um grande hotel. A novela foi então exibida de 3 de abril a $1^{\text {o }}$ de novembro de $1974^{306}$.

Poucos meses depois, seria rompida de forma inesperada essa rotina de Marinho em relação à censura, ora impondo seus próprios vetos, ora acatando cortes do governo, ora tentando reverter proibições. Em 1975, o dono da maior rede de televisão do País iria, de mãos dadas ao seu principal autor comunista, pela primeira vez confrontar publicamente a censura governamental.

\footnotetext{
305 GASPARI, Elio. A ditadura derrotada. São Paulo: Companhia das Letras, 2003, p. 234-235 306 A informação sobre a censura a "O Espigão" está em GOMES, Dias. Apenas um subversivo. Rio de Janeiro: Bertrand Brasil, 1998, p. 278-280; as datas de exibição dessa novela, assim como as de todas as outras utilizadas neste trabalho, são do site teledramaturgia.com.br.
} 
O falso herói de Dias Gomes de fato não havia morrido e voltaria para assombrar o triângulo entre a oposição, o poder e a televisão. 


\subsection{Capítulo 7}

\section{Emprego para Camões}

Dias Gomes conheceu Lauro César Muniz em 1963. Encontraram-se por acaso no escritório de Oswaldo Massaini, que no ano anterior ganhara prestígio em razão da Palma de Ouro para "O Pagador de Promessas", do qual havia sido produtor.

Muniz ainda trabalhava como engenheiro e frequentava a Escola de Artes Dramáticas à noite, mas sua vida estava mudando naquele ano, quando estreou a peça que the daria projeção: "O Santo Milagroso". Ele fora ao escritório de Massaini, na rua do Triunfo, região central de São Paulo, para conversar com o produtor sobre a adaptação cinematográfica de sua obra, o que aconteceria em 1965 (assim como "O Pagador de Promessas", o filme "O Santo Milagroso" teria produção de Massaini, e Leonardo Vilar no papel principal). Ao saírem, Muniz ofereceu uma carona a Dias, que tinha como ídolo duplamente, pelas carreira teatral e trajetória política. Entraram no fusquinha azul marinho novo, com banco de tecido, que o dramaturgo novato pagava à prestação. Era início de noite, fim de expediente, mas São Paulo não tinha trânsito, e o carro parava apenas nos semáforos. Passaram pelas avenidas Ipiranga, São Luís e pela praça da República, até chegar ao hotel em que Dias estava hospedado.

No caminho, o dramaturgo estreante ia se divertindo com a ironia debochada de seu ídolo. Dias falava mal de São Paulo, da paisagem ("Aqui a gente abre a janela e dá de cara com outro prédio") à política ("Um absurdo ter um feriado para a Revolução de 32, aristocrata e separatista"). Ao comentar o premiado filme francês que acabara de ser lançado, "Trinta Anos esta Noite", fingia não entender a densidade do enredo, cujo protagonista vive a angústia da finitude do ser, do conformismo burguês e da insatisfação sexual, até se suicidar ("Imagina um cara se matar só porque não deu uma trepada").

Onze anos de passaram quando os dois trabalharam juntos na TV pela primeira vez. Em 1974, Dias vomitava sangue às golfadas quando Muniz foi chamado às pressas para escrever alguns capítulos de "O Espigão". O dramaturgo paulista, que também militava no PCB, começava a fazer novelas para a Globo. Dias o recebia deitado na cama, de pijama, para tentar, apesar da enfermidade, the orientar sobre os dez capítulos de "O Espigão" que the couberam. Era a primeira vez que contava com ajuda na árdua 
tarefa de produzir uma média de 30 laudas diárias para as telenovelas ${ }^{307}$-esse ritmo insano do processo industrial da produção era, aliás, mais presente em suas críticas às novelas do que qualquer outro aspecto ${ }^{308}$. Janete Clair às vezes aparecia com um café ou uma água para o visitante, mas não opinava. Dias havia sofrido uma bronquiectasia rompimento de uma veia do pulmão-, que os médicos disseram ser consequência de uma tuberculose que tivera à época do golpe militar e que não pudera tratar corretamente por ter ficado foragido.

Muniz estava absolutamente envolvido com o discurso do Partido Comunista e se incomodava com o tema central de "O Espigão", a ecologia, ainda longe de se tornar moda. Achava menor que a luta de classes. Em um dos diálogos que criou, colocou em um personagem o seu pensamento, dizendo algo como "O problema mesmo não é o verde, mas as lutas pelos direitos dos oprimidos". "Não, não", disse Dias ao ler o roteiro. "Pode manter a ecologia", reprimiu, consciente de que abordar os danos do progresso era, além de algo de vanguarda, uma forma de questionar o resultado do "milagre econômico" propagado pela ditadura ao Brasil -no processo de criação, havia feito uma pesquisa para descobrir como o progresso interferia nos relacionamentos humanos, na qual constatara que, quanto mais neuroses e engarrafamentos, menos solidariedade.

Apesar desse pequeno contratempo ideológico, os dois autores comunistas se deram bem e logo depois escreveram juntos o roteiro do filme "O Marginal" -que investiga as razões que fazem de um homem um criminoso-, dirigido por Carlos Manga e produzido por Massaini. Também nesse ano de 1974, Dias e Janete receberam para avaliação a sinopse de "Escalada", que, aprovada, se tornou a primeira novela das $20 \mathrm{~h}$ de Muniz. A trama estreou em 6 de janeiro de 1975 e, de linha realista assim como as de Dias, rompeu com o tom mais melodramático de Janete, comum para esse horário.

Em uma das visitas à casa do casal, Muniz não sabia como agir quando o amigo, que era calvo, surgiu de peruca, todo vaidoso. Janete entrou na sala, e ele, passando a mão pelos fios artificiais, comentou com ela: 'É, acho que vou usar, não está incomodando". "Usa sim, ficou bom", disse a mulher. Dias se virou para Muniz e

\footnotetext{
${ }^{307}$ As informações que envolvem Lauro César Muniz são de entrevista do dramaturgo à autora, em São Paulo, em 11/4/2011.

${ }^{308}$ Esse aspecto da crítica ao processo industrial da telenovela foi observado pela autora na pesquisa dos principais periódicos da época e também está em SACRAMENTO, Igor Pinto. Nos tempos de Dias Gomes - A Trajetória de um intelectual comunista nas tramas comunicacionais, doutorado na UFRJ, 2012, de onde também foi tirada a informação sobre "O Marginal" (p. 327).
} 
perguntou: “O que você achou?". Ele, encabulado, se fingiu de morto: "Achei do quê?”. "Da peruca". "Ah, sim... Ficou boa." A cabeleira falsa seria uma das características pitorescas mais marcantes do adorável vilão de sua próxima novela, "Roque Santeiro". Com Sinhozinho Malta, voltaria a utilizar o coronelismo como metáfora do poder no País -e aproveitaria para brincar com a sua própria vaidade.

A agência de Salvador do SNI registrou, em 31 de janeiro de 1975, uma entrevista de Dias Gomes para a "Tribuna da Bahia"309. Ao encaminhar ao escritório central cópia da reportagem, o informe coloca como o primeiro item de observação que as declarações do dramaturgo contêm "severas críticas à Censura no Brasil”, e grifa alguns trechos. O primeiro a ser destacado, na abertura da entrevista, conta que a "carreira de autor teatral tem sido muito acidentada, devido às frequentes proibições de suas peças, como 'A Invasão' e 'O Berço do Herói', censurada no dia da estreia”. Em seguida, são sublinhadas duas de suas declarações: 1) "Teatro não dava para a minha sobrevivência pois uma censura rígida proibiu meu trabalho" e 2) "Ainda há pouco, o presidente Geisel, numa reunião com atores em Manaus, considerou a nossa censura inepta. Imagine que absurdo proibir a pesquisa da realidade brasileira e taxá-la de subversiva". Ao ser questionado pelo jornalista sobre a forma de agir da censura nas telenovelas, dá detalhes:

Ela proíbe diretamente determinados temas e interfere às vezes na condução da estória. Vou te dar um exemplo. Na novela "Fogo sobre Terra", da Janete, exigiram que o personagem Pedro Azulão fosse preso no capítulo 150. Observe os critérios que ela usa nos horários: às sete horas os temas devem ser mais leves que os das oito, porque, segundo eles, há mais crianças vendo TV às sete. Às dezhoras, são mais liberais, e assim por diante. Depois (irônico) o que não permitiriam à meia-noite? Será que os censores fazem is to para tranquilizar suas próprias consciências? Ou estão no tempo em que se botavam crianças para dormir às seis horas? Veja que absurdo:moral variar com o horário. É possívelque à meia-noite não haja mais moral... Censura é um negócio pré-histórico. ${ }^{310}$

309 SNI, Agência de Salvador, Informação no 0054/19/SNI/ASV/75, 31/1/1975

310 Apertos levaram Dias Gomes à TV. E ele gostou. Tribuna da Bahia, 29/1/1975 
O repórter pergunta se ele vê sinais de abertura. "Acho que sim. Agora, pelo menos, já se pode escrever a palavra censura”. O tom de esperança é cortado pelo de ironia no encerramento da entrevista, quando é questionado se gostaria de "acrescentar alguma coisa para terminar o bate-papo": "Olha, tenho um amigo chamado Camões que foi despedido do jornal 'O Estado de São Paulo'. Sabe se tem emprego aí pra ele?’

Dias se refere à famosa decisão do periódico paulistano de publicar poesias no lugar dos textos censurados. Versos de "Os Lusíadas”, de Camões, apareceram 655 vezes nas páginas do jornal entre 2 de agosto de 1973 e 3 de janeiro de 1975, principal período em que censores do governo se instalaram na Redação do jornal. Em 1974, a manchete "Os Lusíadas - Canto Primeiro" substituiu a notícia de que o governador Laudo Natel havia proibido a divulgação de informações sobre casos de meningite ${ }^{311}$, em meio à grave epidemia que o País enfrentava e sobre a qual era proibido escrever.

Desde março de 1974, quando Geisel tomara posse, o País vivia sob a sua promessa de abertura "lenta, gradativa e segura". Aventava-se a ideia de que finalmente seria criado o Conselho Superior de Censura, previsto em lei desde 1968, que incluiria membros do governo e da sociedade civil para avaliar recursos em cortes ou proibições de obras. Mas também havia sinal de que a repressão cultural não esmorecia, muito pelo contrário. Foi nessa época realizado o primeiro concurso para técnico de Censura, cargo criado pela lei $n^{\circ}$. 5.536, de 1968. O objetivo era reforçar a equipe do Sigab (Serviço de Informação do Gabinete), ligado ao Ministério da Justiça e responsável por telefonemas e bilhetinhos com recados do poder à imprensa. O órgão fazia uma ponte mais direta das ordens do presidente do que o SCDP (Serviço de Censura de Diversões Públicas) -que, desde 1972, com o arrefecimento das guerrilhas urbanas e rurais, assumira o trabalho censório, que havia ficado a cargo do DPF (Departamento de Polícia Federal) ${ }^{312}$ depois do AI-5.

Além da histórica censura à epidemia de meningite, foram proibidos nesse período notícias relativas ao fim do "milagre econômico" e o início da recessão e até a respeito da discussão sobre o possível fim da censura.

\footnotetext{
${ }^{311}$ MAYRINK, José Maria. Acervo mostra as marcas da censura. O Estado de S. Paulo, http://topicos.estadao.com.br/acervo-estadao, 23/5/2012

312 O contexto da censura está em KUSHNIR, Beatriz. Cães de Guarda - Jornalistas e censores do AI5 à Constituição de 1988. São Paulo: Boitempo, 2004, p. 123.
} 
O otimismo cauteloso de Dias Gomes na entrevista, que chamou a atenção do SNI, poderia ser trocado por pessimismo se ele soubesse que, além de a volta da liberdade de expressão estar distante, o governo Geisel iniciaria, acobertado pelo discurso da "abertura", o desbaratamento do Partidão. Até aquele ponto, os pecebistas viviam uma espécie de liberdade vigiada, ainda que episódios de violência tenham ocorrido. Inclusive por razões estratégicas, era importante para o governo resguardar um discurso de esquerda contrário à luta armada, como fazia o PCB, especialmente contando com formadores de opinião de peso, como Dias Gomes. Amigo de Carlos Marighella, que trocou o PCB pela guerrilha, o dramaturgo achava a opção da guerrilha romântica e teve com o guerrilheiro uma discussão sobre o assunto, mas contou que "felizmente, ele teve a delicadeza de não forçar a barra", porque, "se tivesse forçado um pouco, talvez tivesse entrado" 313 .

Após a dura repressão ao movimento estudantil e à luta armada, cujo fim, em novembro de 1974, é marcado pelo aniquilamento da Guerrilha do Araguaia, como relata Gaspari, "em 1975 não havia subversivos no Planalto, estudantes na rua, muito menos terroristas em ação". "Temendo a normalidade, o aparelho de segurança do governo precisava de uma ameaça. Fabricou-a no PCB. Viu no Partidão 'o maior perigo para as instituições democráticas'."’314

Dias Gomes não era mais formalmente um membro do PCB. A saída ocorrera há não muito tempo, por volta de 1973, sem que ele apontasse um motivo único. Em sua autobiografia, iria comparar a desfiliação à "tranquilidade dos casamentos que terminam simplesmente porque os cônjuges se dão conta de que não existem mais motivos para viver juntos".

De minha parte prevaleceu uma profunda autocrítica: após quase 30 anos de militância, chegava à conclusão de que era um péssimo ativista. Certa vez, numa entrevista, defini-me como anarco-marxista-ecumênico, e não estava brincando. Conservando ainda os mesmos ideais que me haviam levado ao Partido, era obrigado a reconhecer que nunca me ajustara à disciplina partidária, que ela me incomodava e me tolhia. Sempre discordara

\footnotetext{
313 RIDENTI, Marcelo. Em busca do povo brasileiro - artistas da revolução, do CPC à era da TV. Rio de Janeiro: Record, 2000, p. 172

314 As informações sobre a censura à recessão e à discussão sobre o fim da censura, além do contexto de repressão ao PCB estão em GASPARI, Elio. A ditadura derrotada. São Paulo: Companhia das Letras, 2003, p. 404, 457-458; a frase de que o Partidão é "o maior perigo para as in stituições democráticas" foi tirada pelo autor de um relatório do CIE (Centro de Informações do Exército).
} 
da linha do Partido em vários aspectos e sempre fora obrigado a recolher minhas discordâncias em nome do centralismo democrático e de um objetivo maior. Procurara ser disciplinado, refreando minha tendência natural à indisciplina. Isso não me fazia feliz nem ajudava o Partido. ${ }^{315}$

Em entrevista a Ridenti, levantou um outro aspecto, além da disciplina: a sensação da falta de apoio -em um momento em que se cristalizavam a sua posição de autor de telenovelas de sucesso e o escudo que essa consagração e a própria influência politica da Globo the conferiam:

Depois de 68, quando a ditadura se tornou mais rígida, e durante o período em que respondi a mais inquéritos policiais-militares, no começo dos anos 70, sentique o Partido me abandonava. Não tive assim, vamos dizer, uma solidariedade efetiva do Partido nos momentos piores por que eu passei. Entendo que também o Partido não estava em condições de fazer isso, porque todo o comitê central estava exilado, muitos tinham sido as sassinados, outros tinham abandonado o País. O Partido estava destroçado. Is so fez com que eu me sentisse muito isolado, na verdade eu me sentia totalmente isolado, um livre atirador, não havia partido nenhum atrás de mim, mas is so forçou um pouco psicologicamente a minha decisão de daí em diante partir como livre atirador mes mo (...) Sempre fui um mal militante e acho que individualmente, como livre atirador, como escritor, era muito mais útil do que militando no Partido, nas tarefas, vamos dizer, cotidianas do Partido ${ }^{316}$.

Apesar da desfiliação, após 30 anos de militância célebre, Dias seguia com a sua imagem colada à do Partido. Inclusive para a máquina da repressão. Em 9 de abril de 1975, seu nome surgiu em um relatório da agência carioca do SNI cujo assunto era "atividade soviética"317. Era a informação de que um representante da rádio e TV de Moscou esteve na Globo a fim de tratar da participação da emissora no Festival Internacional da TV, em abril. A inteligência "esclarece que os soviéticos têm se infiltrado nos meios culturais e artísticos nacionais conquistando e utilizando nomes de projeção, reconhecidamente de esquerda. E que, nos meios de comunicação de massa,

\footnotetext{
315 GOMES, Dias. Apenas um subversivo. Rio de Janeiro: Bertrand Brasil, 1998, p. 268-269

316 Declaração que está na íntegra da entrevista de Dias Gomes a Marcelo Ridenti, da qual o sociólogo utilizou trechos em RIDENTI, Marcelo. Em busca do povo brasileiro - artistas da revolução, do CPC à era da TV. Rio de Janeiro: Record, 2000.

317 SNI, Agência Rio de Janeiro, Informação nº 133/60/75/ARJ/SNI
} 
objetivam divulgar "mensagens subliminares, ou mesmo ostensivas, buscando a massificação de ideias em torno da liberdade do sexo, da 'aldeia global', do desestímulo à luta pelos princípios democráticos, da dissolução da família, da deturpação e desmoralização de medidas governamentais, dos problemas das minorias raciais etc.” E então, para finalizar, o informe cita alguns dos "grandes colaboradores dessas ideias, que se encontram responsáveis pela programação da TV Globo", como (o diretor de jornalismo) Armando Nogueira, Janete Clair e Dias Gomes, que, por "coincidência" (a palavra está entre aspas no original), "produzem e divulgam os programas de maior audiência da emissora". Assim, a preocupação do SNI é a de que a participação da TV Globo no festival russo possa vir a ser uma mostra "irreal do Brasil, de seu povo e de seu governo, já que possivelmente os esquerdistas ali infiltrados deverão ter a missão de representar, através de seus trabalhos, aquela TV'.

O Brasil "irreal” que Dias construía naquele início de 1975 seria representado pela fictícia cidade nordestina de Asa Branca. 


\subsection{Capítulo 8}

\section{Boa noite, censura}

Em uma trilogia formada pelas novelas "Assim na Terra como no Céu", "Bandeira 2" e "Espigão", exibidas entre 1970 e 1974, Dias Gomes abordou problemas urbanos do Brasil tendo o Rio como cenário. Em 1975, o País seria sintetizado pela pequena Asa Branca, um povoado do interior do Nordeste que precisava de um herói falso- para sobreviver. Pela primeira vez -e justamente quando se vivia a esperança, se não do fim, ao menos do abrandamento da censura-, o autor faria uma novela para as 20h, horário de maior audiência, portanto, o principal faturamento do canal.

A decisão foi de Boni, que deixou Janete magoada ao deslocá-la para as 19h, faixa das tramas mais "água com açúcar", considerado de menor prestígio ${ }^{318}$. A estreia da nova produção de Dias, batizada de "Roque Santeiro", estava prevista para o final de agosto e, em 8 de maio, por telefone, o autor conversou sobre sua nova história com Nelson Werneck Sodré, ex-militar e historiador comunista, seu amigo de longa data, o mesmo a quem, no dia do golpe militar, pedira que escrevesse um discurso de resistência para ser lido na Rádio Nacional. Assim se deu a conversa:

- Como é? Já está amarrado no pé do tronco?

- Eu já.

- Já começou?

- Já. Sendo chicoteado pelo feitor.

- Qual é o assunto agora, o tema geral?

- Bem, o tema, muito sigilosamente...

- Diga só aquilo que você puder dizer, porque eu não perguntaria se supusesse que fosse uma...

- Eu estou fazendo uma pequena safadeza. Fiz uma adaptação e um disfarce do "Berço do Herói”.

- Ah, vai ser difícil.

- Mas eu tirei o problema militar, fiz então... torci a coisa um pouco, ficou a mesma coisa, mas...

- Sem farda, não é?

\footnotetext{
318 Sobre a decisão de Boni em relação a Dias e Janete, ver GOMES, Dias. Apenas um subversivo. Rio de Janeiro: Bertrand Brasil, 1998, p. 281; e XEXÉO, Artur. Janete Clair: a usineira de sonhos. Rio de Janeiro: Relume, 2005, p. 79.
} 
- Mas de uma maneira mais simpática e tal, mas no fim dá tudo no mesmo. Eu tenho a impressão que, com isso, ninguém pode dizer nada. Eu tiro a farda e [gargalhadas]

- É, aí é o importante. O importante é você despir o cidadão.

- É. Tirou a farda, acabou, ninguém nota, tenho a impressão que não vão nem perceber nada.

- Você vai despir formalmente e vestir no conteúdo.

- Exatamente.

- [gargalhadas] Tá bom.

- Estou esperando a resposta da Censura.

- Você já mandou os primeiros materiais?

- Não. Mandei a sinopse para que eles se pronunciem, depois é que vamos ver. Mesmo assim, mesmo liberado, fica sujeito, depois, a um exame.

- É, claro, sinopse é sinopse.

- De qualquer maneira, é a liberação inicial. Estou esperando.

- É possível, eles veem muito o lado Federal da coisa.

- Vamos ver, o pessoalda televisão acha que não tem problema.

Uma ou outra pessoa já reconheceu, aí é que está meu receio, porque, percebendo, eles ficam com o pé atrás.

- Não, passaram-se anos e, depois, as pessoas que podemreconhecer são pessoas que não vão fazer nada.

- Meu receio é que se espalhe, afinal de contas, foi ontem.

- Ah, sim, sim.

- Eu tenho a impressão que eles não têm onde se pegar, só se for uma coisa as sim de marcação, e tal.

- É claro, mas você é a liberalidade. Evidentemente, para enfrentar o problema dessa confrontação, se ela ocorrer... Eu penso que não ocorrerá.

- Bem, se eles liberarem, iniciaremos. Não tem problema, o pior será se vetarem de início.

- Dá para des envolverbem?

- Dá, dá muito bem.

- Com aqueles costumes de província.

- É.

- Aquilo é um manancial muito rico.

- Passei o negócio pra cangaço e tal.

- É, cangaço, muito boa ideia, um bom paralelo, aliás, muito adequado [gargalhadas]. ${ }^{319}$

\footnotetext{
319 O diálogo está em BAFFA, Ayrton. Nos porões do SNI - O retrato do monstro de cabeça oca. Rio de Janeiro: Objetiva, 1989, p. 124-125.
} 
Nos bastidores da produção da novela, circulavam boatos de que "Roque Santeiro" era uma adaptação de "O Berço do Herói”, mas os comentários eram velados, todos temiam que o governo pudesse desconfiar de que a novela tinha praticamente a mesma história da peça censurada. A fim de driblar a censura, Dias colocou, no lugar de Cabo Jorge, Roque, um fabricante de imagens de santos que havia sido dado como morto ao tentar proteger a cidade em uma briga com um bandido. Ele reapareceria vivo 17 anos depois, ameaçando o progresso da cidade, que passara a girar em torno de seu falso heró́smo, gerando turismo em busca de seus "milagres". Major Chico Manga virou Sinhozinho Malta e Antonieta, a Viúva Porcina (para a versão televisiva, ele inspirou-se em Adélia, arrumadeira de pensão em que morara nos anos 1940, que prestava favores sexuais aos estudantes e acabou se casando com um deles, filho de rico usineiro pernambucano $)^{320}$. A história se passaria em 1960, antes, porém, do golpe militar, a fim de evitar maiores problemas. O autor confidenciou a Boni que a novela era uma versão da peça, falou inclusive que havia sido editada em livro, mas que iria tirar os aspectos mais sensíveis, aproveitando apenas os personagens. À época da apresentação da sinopse, o executivo procurou se certificar: "Você não vai dar conotação política, né?". "Não", ele respondeu. "Vou apenas usar a história, que é boa." 321

A resposta inicial do governo que Dias esperava chegou em 16 de maio, em oficio encaminhado à Globo por Rogério Nunes, diretor da DCDP (Divisão de Censura e Divertimento Público) ${ }^{322}$. Ele solicitava a apresentação dos textos dos capítulos, em grupos de 20 a 30. A exigência se justifica va, explicou, porque a sinopse de "A Fabulosa Estória de Roque Santeiro e sua Viúva, a que Era sem Nunca Ter Sido" -nome provisório da novela - tratava de "problemas sociais da região nordestina envolvendo diferentes classes, o que requer da Censura, na apreciação dos episódios, o máximo de atenção e cuidado para com as cenas e diálogos". Como a Globo pedia a exibição para as 20h, a DCDP necessitava dos capítulos para se manifestar sobre a classificação etária, dizia o oficio, "a ser depois confirmada com a verificação dos tapes". Em 5 de junho,

\footnotetext{
${ }^{320}$ As informações sobre a produção são de entrevista à autora de Emiliano Queiroz em 1\%/9/2011, de nota da Folha de S.Paulo de 10/07/1975 (Ilustrada, pág. 40) e de FILHO, Daniel. Antes que me esqueçam. Rio de Janeiro: Editora Guanabara, $3^{\mathrm{a}}$ edição, 1988, p. 175-177; sobre a inspiração para a Vúva Porcina, GOMES, Dias. Apenas um subversivo. Rio de Janeiro: Bertrand Brasil, 1998, p. 59.

321 Entrevista de Boni à autora, no Rio, em 12/9/2011.

322 Divisão de Censura de Diversões Públicas, Ofício no 534/75-SC/DCPD, 16/5/1975
} 
Edgardo Erichsen, o diretor da Globo cujo papel era fazer a ponte entre os militares e a emissora, encaminhou os dez primeiros capítulos de "Roque Santeiro". Pouco depois, no dia 24, mandou para a Censura um pacote que ia do $11^{\circ}$ ao $20^{\circ}$ episódio.

Enquanto isso, a produção da novela, que seria a primeira em cores às $20 \mathrm{~h}$, seguia a todo o vapor. A cidade cenográfica, construída em Guaratiba, a uma hora de ônibus do Rio, consumiu dois meses de trabalho e quase 400 mil cruzeiros, um investimento bem acima da média. Durante quase quatro meses, o elenco ia e voltava diariamente. Além disso, dois estúdios foram alugados de Herbert Richers. Daniel Filho assumiu a direção e escolheu o elenco a dedo. Francisco Cuoco foi escalado para ser Roque; Lima Duarte interpretaria Malta e Betty Faria, a Viúva Porcina. Houve um intenso trabalho de pesquisa e laboratório com os atores, com a contratação até de psicólogos. Mais comum no cinema, esse tipo de preparo era uma novidade na televisão.

A direção de arte ficou a cargo dos responsáveis pela encenação de "A Paixão de Cristo", em Nova Jerusalém, Pernambuco. A ideia era dar um tratamento menos exuberante, mais regional e realista. O elenco trabalhou o sotaque e assistiu a filmes e a documentários sobre o Nordeste e as crenças brasileiras. O objetivo era deixar claro que a trama não era uma crítica às pessoas que acreditam em milagres. Daniel Filho queria mostrar "que todos nós acreditamos em milagres, que era muito fácil a gente pertencer a Asa Branca". O ator Emiliano Queiroz, que interpretava Zé das Medalhas (comerciante que vendia medalhinhas e outros souvenires com a imagem de Roque), levou o pai, ourives, joalheiro e topógrafo, para uma palestra aos colegas. Outros artistas foram chamados para falar sobre cordel e ajudar a criar o clima do interior da Bahia. No início de julho, tiveram início as gravações em estúdios, além de algumas cenas externas. Cenas aéreas foram registradas em fazendas de Recife. Era grande a euforia de fazer a primeira novela em cores das $20 \mathrm{~h}$, especialmente por ser a estreia de Dias Gomes no horário. O autor acompanhava tudo de perto, da escalação do elenco às gravações.

Em 30 de junho, menos de uma semana depois de a Globo ter enviado a segunda remessa de capítulos da novela para a Censura, a DCDP redigiu um parecer a respeito de "O Berço do Herói”, sem que nenhuma montagem da peça tivesse sido solicitada. O documento, com texto truncado e erros de português, é assinado pelo técnico de censura Antonio Gomes Ferreira. Vale transcrevê-lo. 
Peça desataviada de aspectos ideológicos mas contundente em suas afirmações e ataques ao modus faciendi de figuras consideradas possuidores de valores morais acima da média dos seus compatriotas... É uma peça afoita e carente de estudo coerente e, principalmente, patriótico, para esclarecer ou desanuviar possíveis dúvidas que certamente advirão a todos que venham tomar conhecimento de fatos semelhantes. O erro é possívela todo ser humano, a qualquer povo, mas não é admissível que ele se perpetue conscientemente, como efeito do orgulho ou da vaidade ou da loucura do poder, do domínio... Se há erro, que seja solucionado com tal, porque a Pátria só é digna dos seus filhos, se se fundamente na verdade, na honra, no espírito de liberdade e respeito aos valores indeléveis da virtude, que dignifica o homem e imortaliza um povo, diante de Deus e do consenso nas nações.

É muitas vezes irreverente, tendencioso e prosélito. Sua mensagem exige plateia esclarecida, evitando assim deturpações e generalizações. Seu erro é criar nos menos esclarecidos a dúvida sobre os demais vultos de nossa história, e agredir os militares da Revolução, como se encontra nas orelhas do livro.

Relata o DRAMA do pracinha da FEB -CABO JORGE- tido como herói e, posteriormente, surgindo são e salvo, louco de saudades de as terra e de sua gente. Mas a vaidade dos seus e a insanidade dos usurpadores deramlhe morte desastrosa numbordel, preparada friamente, covardemente. ${ }^{323}$

Na conclusão, o censor aponta as 12 páginas em que foram feitos cortes por ferirem o artigo 41 do decreto 20.493/46, o mesmo citado na censura que proibira a estreia da peça dez anos antes. À época, o secretário de Segurança Pública do Rio, Gustavo Borges, dissera que a obra violava três alíneas das oito presentes no artigo ("a", “c" e ' $P$ '). Agora, para o técnico de censura, eram sete das oito, apenas a alínea "e", que vetada conteúdo que pudesse "prejudicar a cordialidade das relações com outros povos", não foi citada. Diante disso, o parecer sugere a liberação para maiores de 18 anos, "solicitando especial atenção para o ensaio geral e fiscalização permanente durante o espetáculo, visto a peça se propor exploração ou improvizações [sic] negativas, de fundo ideológico, ou antirevolucionário ou regime vigente [sic]".

Apenas três dias após esse exame sobre a peça, dois técnicos de censura da mesma DCDP entregaram parecer a respeito da novela, avaliando os capítulos enviados

\footnotetext{
${ }^{323}$ Ministério da Justiça, Departamento de Polícia Federal, Divisão de Censura de Diversões Públicas, Parecer $n^{\circ}$ 5848/75, 30/6/1975
} 
pela Globo. Maria José Bezerra de Lima e L. Fernando começam a análise com um resumo da história, para concluir que ela contém as seguintes "implicações":

\author{
Amores clandestinos; \\ Visitas de rapazes às moças, após as 23 horas; \\ Tendência ao amor livre (João Ligeiro); \\ Sabotagem (o corte de energia pelo professor); \\ Distúrbios civis (as beatas contra a boate); \\ Agitação conclamando o povo a participar, em favor dos bons \\ costumes, contrariando o alvará da Prefeitura, envolvendo o padre como \\ mentor intelectual; \\ Depreciação da autoridade do delegado; \\ Justiça pelas próprias mãos; \\ Referência ao terrorismo, levando a população ao pânico..$^{324}$
}

A liberação se dá com a condição de que a novela seja situada nos anos 1960, e não na época atual. Para isso, exigem, é preciso tirar referências da atualidade, como à Jaqueline Onassis, minissaia, "Programa Silvio Santos" e "Jornal Nacional". Segue então uma lista de seis cortes, como as palavras "brasileira" (em "realidade brasileira") e "sabotagem, bomba", além de "todas as cenas do quarto de Porcina, onde ela e Roberto aparecem [Roberto Matias, ator que faz o papel de Roque Santeiro em um filme sobre o herói]". Apesar disso, os técnicos encerram o parecer afirmando que, "superadas as implicações supramencionadas e atendidas as partes condicionadas, somos pela liberação da presente novela para o horário das 20 horas, ou seja, imprópria para menores de 12 anos, vez que o tema abordado não o influirá negativamente na formação psicossocial e moral do jovem adolescente dos dias atuais".

No dia seguinte, 4 de julho, Rogério Nunes enviou ofício à Globo informando que, a partir da verificação dos capítulos 1 a 20, a novela havia sido aprovada para as 20h, mas que a liberação estava condicionada à verificação das gravações, o que não era praxe nem estava previsto na lei. Ele reforça as condições colocadas pelos técnicos no parecer, afirmando que "merecem especial cuidado da direção as cenas em que Tito e Linda se encontram deitados, assistidas pelo marido". O último parágrafo tem tom mais ameaçador:

\footnotetext{
324 Ministério da Justiça, Departamento de Polícia Federal, Divisão de Censura de Diversões Públicas, Parecer $n^{\circ} 6114 / 75,3 / 7 / 1975$
} 
Permanece a exigência da remessa antecipada dos textos dos capítulos subsequentes e a produção deve cuidar de manter os assuntos no mesmo nível apresentado até agora, pos to que, ocorrendo maiores implicações de ordem moral ou social, poderão servetados os outros capítulos ou mudado o horário da novela. ${ }^{325}$

Três dias depois de assinar esse documento, em 7 de julho, Nunes mandou arquivar o parecer sobre a peça "O Berço do Herói”. À caneta, sublinhou o seguinte parágrafo datilografado pelos técnicos: "Seu erro é criar nos menos esclarecidos a dúvida sobre os demais vultos de nossa história e agredir os militares da Revolução, como se encontra na orelha do livro". O diretor da DCDP anotou, à mão, que não existia pedido de liberação da peça. "O exame foi determinado de ofício em virtude da apresentação assinada por Ênio Silveira, o que constitui a orelha do livro", justificou. E mandou "formar processo e arquivar". Era um claro indício de que os militares queriam avaliar o conteúdo da peça antes de decidir sobre a novela porque certamente sabiam da "safadeza" que Dias Gomes aprontara, driblando a censura imposta à obra em 1965.

Enquanto isso, como era de se esperar, a repercussão sobre a nova novela das oito seguia forte na imprensa. Em meio a uma série de notas a respeito da escalação do elenco e do início das gravações, em 15 de julho a "Ilustrada", da "Folha de S.Paulo", publicou uma entrevista com Lima Duarte, que se preparava para interpretar Sinhozinho Malta. Ele falava de sua carreira na TV, após a experiência de conhecer o País através do Teatro Arena: “A televisão é o meu campo de trabalho, é onde estou, uma opção. Por isso meu sonho é fazer o Brasil nela". Sobre a expectativa para a estreia de "Roque Santeiro", comentou:

O público das 8 horas da noite estava merecendo uma mudança no horário, que aconteceu a partir de "Escalada", de Lauro César Muniz. Tanto ele como Dias Gomes são autores que têm o espírito do Brasil. Agora é preciso que também a parte de realização, interpretação, tenha essa brasilidade. As pessoas que trabalham com a arte no Brasil se instruem através de fontes universais sem aprender uma lição fundamental que elas ensinam: que a gente pode ser universal na medida em que se aprofundar no

325 Divisão de Censura de Diversões Públicas, ofício sem número, 4/7/1975 
que é nosso, porque esse ninguém vai saber fazer melhor. Porque um Laurence Olivier é um excelente Hamlet, mas vai ele fazer um Zeca Diabo pra ver quem é o melhor. Não há universo maior do que o da gente. Um artista deve ser o intérprete do seu tempo e da sua gente. Brasil não é essa vidinha Zona Sul, ess e chopinho, es se biquíni, esse solzinho. ${ }^{326}$

A imprensa demonstrava ter informações sobre as dificuldades com a censura. Em 12 de julho, nota da "Ilustrada" havia dito que a novela poderia estrear às $20 \mathrm{~h}$ ou às 22h ("Tudo depende da Censura"). No dia 15, colocou o seguinte aposto em "Roque Santeiro": "a nova novela das oito, provavelmente".

Em pouco tempo começaria a ficar mais claro o que "provavelmente" iria acontecer, e que os militares não estavam para aceitar "safadezas" de autores comunistas. O País enfrentava a nova onda de perseguição ao PCB, a máquina repressiva estava fora de controle, e a inteligência idem, prestando-se a disputas internas entre os militares e até a bisbilhotar a vida do próprio presidente (Geisel descobrira que o CIE, Centro de Informações do Exército, produzia uma lista diária com todas as pessoas que iam visitá-lo em casa e teve dificuldades para encerrar a xeretagem ${ }^{327}$ ).

O desespero dos militares se agravara em novembro de 1974, com as eleições legislativas, cujo resultado foi péssimo para o governo. Representante da oposição, o MDB recebeu 4 milhões de votos a mais do que a Arena, governista, para o Senado, ficando com 16 das 22 vagas em disputa. Na Câmara, conseguiu 44\% das vagas (161 contra 203 da Arena), além da maioria em assembleias de Estados importantes, como São Paulo, Rio de Janeiro e Rio Grande do $\mathrm{Sul}^{328}$. Tornara-se evidente a falta de respaldo à ditadura na sociedade, que, diante do resultado eleitoral e do fim da luta armada, colocara a volta da democracia no centro do debate nacional.

Em 16 de junho, um informe do CIE (Centro de Informação do Exército), intitulado "Estudo e Apreciação sobre a Revolução de 64", "sustentava que a abertura ‘já andou demais', que era 'o momento de envolvê-la em hábil entorpecimento"”. Especificamente sobre a censura, defendia:

\footnotetext{
${ }^{326}$ LAGO, Graça. Fazer televisão, a alternativa de Lima Duarte. Folha de S.Paulo, São Paulo, p. 40, $15 / 7 / 1975$

327 GASPARI, Elio. A ditadura encurralada. São Paulo: Companhia das Letras, 2004, p. 105-106 ${ }^{328}$ SCHWARCZ, Lilia M. e STARLING, Heloisa M. Brasil: uma biografia. São Paulo: Companhia das Letras, 2015, p. 469; BALTAZHAR, Ricardo et al. Tudo sobre a ditadura militar. Folha de S.Paulo, 23/3/2014; disponível em arte.folha.uol.com.br/especiais/2014/03/23/o-golpe-e-a-ditadura-militar
} 
A abertura pode realizar-se com o setor de comunicações, mas sempre sob controle. Deve-se reconhecer que a censura, efetivamente, exercia in loco por pessoas tantas vezes despreparadas e sem discernimento lançou descrédito sobre esse necessário meio de controle. Impõe-se uma reestruturação. Escolher pessoas a dedo. Para cada jornal de grande cidade, para cada grupo de publicações não muito empenhativas, haveria um censor. Assim também para cada canal de televisão bastaria um único censor. Não teriam sua sede no órgão de comunicação, a não serque fosse impossível outro modo. Nem visitariam o órgão. Havendo algum órgão comunicador que se recuse a colaborar a autocensurar-se (será talvez o caso de $\mathrm{O}$ Estado de $\mathrm{S}$. Paulo), um censorse instalaria outra vez dentro do órgão de comunicação. Só que, garantia-se, seria um censor inteligente e bem-dotado, incapaz de mesquinharias e culto. Abertura vigiada nos meios do comunicação, sim [grifo nosso]. ${ }^{329}$

O mesmo relatório afirmava que o "combate atual do mundo é PELA POSSE DA MENTE HUMANA", assim mesmo, com letras maiúsculas. Nesse clima de pressão e de desgoverno, Geisel foi à TV em $1^{\circ}$ de agosto, em cadeia nacional, deixar claro os limites da "distensão". Em um longo discurso com 18 páginas, 3.704 palavras -foi de saneamento básico a salário-maternidade-, guardou as últimas para esclarecer que os falatórios sobre a abertura "absolutamente não correspondem à realidade, mas constituem fruto da imaginação e, por vezes, além do que contém de intriga e de ação negativista, representam apenas o desejo íntimo de seus autores". Conhecido como "páde-cal", o pronunciamento rejeitou o fim do AI-5, a revogação do decreto-lei $\mathrm{n}^{\circ} 477$ (que previa punição a alunos e professores "subversivos"), a revisão da Lei de Segurança Nacional, a promulgação de uma anistia ampla e afirmou textualmente que "o governo não abrirá mão dos poderes excepcionais de que dispõe" 330 . E encerrou: "Assim, ajude-nos Deus!"

Deus nos acuda foi a correria para gravar e editar os dez primeiros capítulos de "Roque Santeiro" a tempo de serem liberados pela Censura. A estreia estava marcada para 27 de agosto, e no dia 14 do mês a Globo encaminhou ofício a Rogério Nunes informando que estavam à disposição os seis primeiros episódios, marcando para o dia seguinte a exibição para os censores. No dia 15, uma sexta-feira, foi avaliado esse

\footnotetext{
329 BAFFA, Ayrton. Nos porões do SNI - O retrato do monstro de cabeça oca. Rio de Janeiro: Objetiva, 1989, p. 49-55

${ }^{330}$ Para o descontrole do governo, GASPARI, Elio. A ditadura encurralada. São Paulo: Companhia das Letras, 2004, p. 81-126; para o discurso pá-de-cal, íntegra no site http://www.biblioteca.presidencia.gov.br/ e NAPOLITANO, Marcos. 1964 - História do regime militar brasileiro. São Paulo: Contexto, 2014, p. 247.
} 
primeiro pacote, e Nunes recebeu novo informe da emissora, marcando para a segundafeira seguinte, dia 18, a apresentação do sétimo capítulo ao décimo.

Em 20 de agosto, a uma semana do lançamento, veio a bomba. A mesma censora que havia lido a íntegra dos 20 primeiros capítulos e os aprovados para as 20h, "vez que o tema abordado não influirá negativamente na formação psicossocial e moral do jovem adolescente dos dias atuais", mudou misteriosamente de opinião. Ao assistir aos tapes, Maria José Bezerra de Lima, em parceria com Gilberto Pereira Campos, escreveu:

Efetivamente, os dez capítulos iniciais da telenovela "ROQUE SANTEIRO”, de autoria de Dias Gomes, conduzem-se numa atmos fera fortemente acentuada de movimentação dramática e psicológica, tornando, sobremaneira, sua apresentação inadequada para o telespectador juvenil, quer pelo impacto de cenas e diálogos, quer pela mensagem, quer pelo grau de influência dos personagens (revoltados, prostitutas, adúlteros, levianos, aproveitadores, fanáticos etc.).

É, sem dúvida, uma estória mística de cunho sócio-rural com matizes de parareligiosidade [sic] e nela se envolvem os habitantes de um vilarejo Asa Branca-, que cresceu à sombra de um mito. Entretanto este mito, Roque Santeiro, tido como santo milagreiro, não morrera heroicamente em defesa de sua cidade, mas continuava vivo, des frutando do produto de seu roubo, dinheiro e objetos sacros.

De um lado, verifica-se em toda a extensão dos capítulos examinados a verticalização de apelos negativos que vão desde cenas irreverentes e diálogos gratuitos até a indução da crendice.

Por outro lado, nota-se que a ofensa à moral, à ordem pública e aos bons costumes, bem como o achincalhe à igreja, a emotividade exagerada e os regis tros contínuos de cenas amorosas (para os quais sugerimos veto [grifo do original], considerando sua veiculação na TEVÊ) a tornam, flagrantemente, problemática, cujos diálogos (ver, em especial, capítulo 2, pág. 17 [fala do personagem Roberto Matias: “O pior é que acabei ficando na mão. Nem a filha do coronel, nem as pistoleiras, nada. Jejum total'] extrapolam a regularidade da linguagem televisiva.

Em síntese, há aspectos intoleráveis para a faixa das 20 horas. A começar pelo tema-mensagem, que é, sem sombra de dúvida, ímpar para este horário, mormente quando se sabe, por analogia, que o mesmo geralmente aborda temas atenuados, sem afetações e implicações de quaisquerordem. 
Enfim, se liberada para o horário das 20 horas, o seu

desenvolvimento, fatalmente, levará o agente fruidor juvenil a receber carga incomum de apelos e de influências, por certo, negativas.

Em vista do exposto, opinamos, feitos os cortes assinalados abaixo, e levando em consideração a sua forte temática, negativa, sob todos os sentidos, para uma classificação etária inferior, pela liberação da telenovela “ROQUE SANTEIRO” com a IMPROPRIEDADE DE 16 ANOS, ou seja, exibição a partir das 22 horas. $^{331}$

Além de mudar a classificação para as $22 \mathrm{~h}$, os técnicos ainda exigiram diversos cortes, alguns deles de cenas inteiras. No mesmo dia, Rogério Nunes enviou ofício à Globo, informando a nova classificação ${ }^{332}$. Segundo ele, "a censura procedida nos dez primeiros capítulos gravados permitiu uma melhor avaliação da novela por parte deste órgão, levando-o, consequentemente, a reconhecer que há aspectos intoleráveis para a faixa das 20:00 horas". A classificação ficava para as 22h, informou, além de alertar: "Sujeita, ainda, a vários cortes, a fim de suprimir cenas e situações inconvenientes pela televisão".

Além de drásticos, os cortes tinha, algumas vezes, motivações incompreensíveis. No capítulo 1, por exemplo, Sinhozinho Malta comentava com a Viúva Porcina as críticas que estava recebendo por ter construído um aeroporto que passava em suas terras só para valorizá-las. Dizia que a obra iria beneficiar a cidade e, já que tinha que valorizar as terras de alguém, melhor que fosse as dele. Nenhum corte nisso, apenas na última frase: "Que fui quem pariu a ideia. Tô certo ou tô errado?". A palavra "pariu" estava grifada, um indício de que a questão aí pudesse ter sido moral... Já o corte seguinte, no mesmo capítulo, era claramente político, em uma frase inteira de Roberto Matias, ator que estava na cidade para um filme em que faria o papel de Roque Santeiro: "E quando a gente reclama melhores condições de trabalho pro ator, dizem que a gente é ditador subversivo". Já uma cena do capítulo 2 censurada na íntegra mistura a questão moral (boate) à política (incitação a distúrbios civis, conforme apontou a Censura), além de envolver a igreja. Na missa, o padre se dirige aos fiéis:

\footnotetext{
${ }^{331}$ Ministério da Justiça, Departamento de Polícia Federal, Divisão de Censura de Diversões Públicas, Parecer 7019/75, 20/8/1975

332 Divisão de Censura de Diversões Públicas, ofício sem número, 20/8/1975
} 
Padre: Meus amigos, com tudo is so Paulo quis dizer que o culto da carne em lugar do espírito leva a perdição. E eu quis lembrar as palavras do profeta neste momento porque, como todos sabem, anuncia-se para depois de amanhã, nesta cidade, a abertura de uma casa noturna, um lugar onde será feito, todas as noites, o culto da carne. O que equivale a dizer, meus irmãos, o culto do demônio. Vamos permitir que isso aconteça?

(Close de Pombinha e Mocinha, que balançam negativamente com a cabeça.)

Padre: Vamos assistir de braços cruzados a essa invasão do vício e do pecado em nossos costumes?

(As beatas bebem, fanatizadas, as palavras do padre.)

Padre: Dizem que is so é resultado do progresso, do crescimento da cidade... O preço que todos devemos pagar...

(O padre solta uma gargalhada sarcástica.)

Padre: Mentira! Conversa! Patifaria! Safadeza! O patrono desta cidade, Roque Santeiro, se voltasse hoje à terra onde nasceu, ia ficar escandalizado com tanta hipocrisia, tanta sem-vergonhice. ${ }^{333}$

Mais para frente, em uma fala do diretor do filme que está sendo rodado em Asa Branca sobre Roque Santeiro, Dias Gomes provoca a Censura. E o comentário do personagem sobre a exigência da Viúva Porcina de ler o roteiro do filme é cortado pelos censores: "Tem mais esta. Ainda tenho uma censora! Fazer cinema no Brasil é pra herói! Só pra herói!"

São violentos os cortes exigidos para os capítulos 9 e 10. No 9 , uma sequência inteira em que a filha de Sinhozinho Malta diz a ele desconfiar de que a mãe não se suicidara, e sim havia sido assassinada. Ao final, tem início a passagem em que o ator Roberto Matias, disfarçado de padre, aparece para um encontro amoroso com Porcina. Não há nada forte do ponto de vista sexual na cena, e o problema parece ser mesmo o fato de ele estar de batina. Essa passagem e a sua continuação, que ocupam boa parte do capítulo 10 , foram completamente riscados.

Apesar da quantidade de cortes, seria possível realizá-los a tempo da estreia. A dificuldade era remanejar a novela das $22 \mathrm{~h}$ para as $20 \mathrm{~h}$. Estava no ar "Gabriela", uma adaptação de Walter George Durst do romance de Jorge Amado, que sofria também com

\footnotetext{
${ }^{333}$ Ministério da Justiça, Departamento de Polícia Federal, Divisão de Censura de Diversões Públicas, Parecer 7019/75, 20/8/1975; script com cortes em anexo
} 
exigências da Censura ${ }^{334}$. A estratégia foi tentar liberá-la para o horário anterior, enquanto se recorria de todas as formas da classificação de "Roque Santeiro".

Àquela altura, já se instalava o pânico na equipe de produção. Mas o pensamento ainda era de que, como sempre ocorria, a Globo chegaria a um entendimento com o governo. Daniel Filho corria para adiantar ao máximo as gravações. Havia naquele momento 30 capítulos gravados, sendo os dez primeiros, os enviados para a Censura, editados e finalizados. A uma semana da estreia, enquanto gravava uma cena, o diretor, ao ver a dedicação da equipe e sabendo da ameaça que a novela sofria, resolveu reunir a todos e alertar sobre o risco.

Com as chamadas no ar, os "assessores militares" da Globo se movimentavam a fim de reverter a situação. Walter Clark foi mais de uma vez à Brasília negociar com representantes do governo. Entre os boatos que chegavam à Globo, um deles foi o de que a novela fora vetada por ter preconceito religioso, racial e por fazer parte de um plano subversivo para desestabilizar o País. A informação teria sido obtida em depoimento de um comunista preso. Boni questionou Dias, que negou. O executivo voltou a conferir o texto e nada encontrou que pudesse respaldar essa teoria conspiratória $^{335}$.

A Globo tanto acreditava que o veto seria revogado que só enviou o pedido para classificar "Gabriela" para as 20h, a fim de exibir "Roque Santeiro" às 22h, no dia do último capítulo de "Escalada". Ou seja, na véspera da estreia da nova novela. "Gabriela" terminaria em outubro, assim, a Globo teria três meses para elaborar uma nova produção para as $20 \mathrm{~h}$. A resposta foi rápida, e desta vez com peso maior. Não foi assinada Rogério Nunes, diretor da Divisão de Censura e Diversões Públicas (DCDP), mas por Moacyr Coelho, diretor-geral da Polícia Federal. Se o País esperava avançar para uma abertura, o oficio era demonstração de retrocesso, afinal, a Censura havia

\footnotetext{
${ }^{334}$ As informações sobre a censura de "Roque Santeiro" estão nos documentos da DCDP levantados para esta pesquisa; para a informação de que "Gabriela" sofria vários cortes, MARCELINO, Douglas Attila. Para além da moral e dos bons costumes: a DCDP e a censura televisiva no regime militar, monografia de graduação em história na UFRJ, 2004, apud SACRAMENTO, Igor Pinto. Nos tempos de Dias Gomes - A Trajetória de um intelectual comunista nas tramas comunicacionais, doutorado na UFRJ, 2012, p 330.

335 Para a decisão de Daniel Filho, FILHO, Daniel. Antes que me esqueçam. Rio de Janeiro: Editora Guanabara, $3^{\mathrm{a}}$ edição, 1988, p 177; informações sobre Boni são de sua entrevis ta à autora, no Rio, em 12/9/2011; para a ida de Walter Clark à Brasília, reportagem Um herói impróprio para as 20 h. Jornal da Tarde, p. 19, 27/8/1975 [matéria não assinada], que fala também que Marinho teria viajado para a capital federal com o objetivo de tratar da censura à novela; na lembrança de Boni, em entrevista à autora, eles não viajaram à Brasília para negociar como o governo.
} 
saído das atribuições diretas do Departamento da Polícia Federal (DPF) em 1972, ao menos teoricamente -ainda que a DCDP estivesse, no organograma, subordinada ao DPF, gozava de certa autonomia. Apesar de, na abertura do informe à Globo, o coronel Coelho ser quase amável, uma versão torta do "hay que endurecer, sin perder la ternura", a resposta que ele dá em seguida está longe de ser terna.

Apraz-me acusaro recebimento do ofício sem número, de hoje datada, no qual essa empresa solicita modificação de horário da telenovela intitulada "GABRIELA" (...).

Em atenção ao assunto, cumpre-me informar a V. S. que não nos é dado o prazer de atender à solicitada, visto que a referida novela vem mostrando, ultimamente, cenas e situações que agridem os padrões normais da vida no lar e na sociedade, tornando o espetáculo inconveniente para qualquer horário de televisão, mas que a Censura, em virtude de haver estabelecido no início uma classificação etária, e ciente de que se aproxima do seu término, vem tolerando as apresentações, para evitar transtornos à emissora, com a retirada de todos os capítulos comprometedores, co mo também pelo fato de não haver, em época oportuna, advertido para a possibilidade de interromper o programa, pelos motivos indicados. ${ }^{336}$

O diretor da Polícia Federal, dessa forma, ameaça veladamente tirar "Gabriela" do ar, o que deixaria a Globo sem a novela das oito e a das dez, seus dois principais programas. Ele explica por quê:

Como exemplo de inconveniências pode-se apontar o personagem que mantém ostensivamente casa com sua concubina; a dona do cabaré que promove festa comemorativa da amancebia de sua afilhada com influente político, de que resultou na agressão à amásia deste, contratada por sua mulher; o chefe de família que mantém contato voluptuoso com a empregada, em sua própria casa; o personagemque revela anomalia sexual; favorecimento a autor de crime de homicídio, por parte de autoridades e outros aspectos desaconselháveis para espetáculos televisionados. ${ }^{337}$

\footnotetext{
336 Serviço Público Federal, ofício sem número, 26/8/1975
}

${ }^{337}$ Ibidem 
Ao final, vem uma aberta intimidação em relação a "Roque Santeiro", a mostrar que a "liberação" para as $22 \mathrm{~h}$ na verdade significava proibição taxativa. Estava mais do que claro que seria melhor a Globo nem cogitar um contorcionismo para colocar a obra no ar, fosse qual fosse o horário.

Relativamente à novela “A FABULOSA ESTÓRIA DE ROQUE SANTEIRO”, cujos dez primeiros capítulos gravados foram liberados para apresentações após as 22:00 horas, dá para notar, já no seu início normalmente suavizado pela produção para obter a classificação etária baixaque será conduzida numa atmosfera fortemente acentuada de movimentação dramática e psicológica, tornando sua transmissão inadequada para o telespectador juvenil, quer pelo impacto de cenas e diálogos, quanto pela mensagem, quer pelo grau de influência dos personagens, dentre estes aparecendo revoltados, prostitutas, adúlteros, levianos, aproveitadores, fanáticos etc.

A forte temática -negativa sobre todos os aspectos-poderá conduzir a uma situação intolerável para o meio de comunicação a que se destina, o que somente revelará o exame da gravação dos capítulos subsequentes. Isto ocorrendo, a novela será, inevitavelmente, proibida, ficando desde já a critério dessa empresa assumir o risco de ver interrompida, a qualquer tempo, a transmissão do programa [grifo nosso], visto que a Divisão de Censura de Diversões Públicas tem instruções no sentido de não mais tolerar, como o faz com a novela "GABRIELA", as cenas e situações que agridam os padrões normais da vida no lar e na sociedade ou que possamferir, por qualquer forma, a dignidade ou o interes se nacional. ${ }^{338}$

Quando o documento chegou à Globo, foi entregue a Boni, que imediatamente avisou Roberto Marinho. Levou uma bronca do chefe: "Você colocou a empresa em risco. Como você põe a empresa em risco dessa forma?" O executivo argumentou que não havia visto nada que pudesse ser censurado. Que lera os capítulos, assistira às gravações. Não existia problema com militares, preconceito religioso ou racial. Era uma grande comédia, por que haveria de se preocupar? "Era rodar e correr pro abraço."

O dono da Globo quis ler os capítulos e assistir às fitas. Fortemente pressionado, Boni só não abandonou a emissora naquele momento porque pensava que haveria uma solução, e queria brigar por ela. Ele sugeriu ao patrão que procurasse o ministro da

${ }^{338}$ Ibidem 
Justiça, Armando Falcão, de quem o empresário era amigo próximo. Mas os dois estavam brigados, e Marinho não quis dar o braço a torcer, queria marcar posição: "Ele não pode fazer isso comigo", respondeu.

Rapidamente as cópias dos roteiros e os tapes formam levados à sala de Marinho, que leu os textos e assistiu a uns cinco episódios ao lado de Boni. O tom era de humor. Sinhozinho, que abria um armário para escolher suas perucas, lambia a mão da Viúva Porcina imitando cachorrinho. Havia um lobisomem. Na porta da igreja, uma placa dizia ser proibido entrar de bermuda, shorts e frente única. O padre, interpretado por Milton Gonçalves, dizia que "quem tem fé voa". E a política aparecia mais diretamente em uma frase de um personagem que afirmava que "a oposição só sabe contestar, não sabe governar" 339 . Roberto Marinho concordou com Boni: o veto era "sacanagem". "Não tem nada para censurar", afirmou. Achou, inclusive, que podia haver algo de pessoal, talvez com o dedo de Falcão para prejudicá-lo. Ou, quem sabe, a questão teria sido levada ao ministro, que preferiu não agir para evitar ser acusado de ajudar o amigo. A situação era tão inesperada e fora dos padrões que se buscavam hipóteses das mais variadas, algo que pudesse acrescentar lógica à proibição. Fosse qual fosse a teoria aventada, o fato é que Marinho ficou muito irritado. E a sua decisão surpreendeu a todos: fazer um editorial para ser lido no "Jornal Nacional" no dia seguinte, quando "Roque Santeiro" deveria estrear. Para Boni, o "Dr. Roberto", como era chamado por seus funcionários, se sentiu "humilhado":

Acho que ele se sentiu humilhado, preferiu o editorial. O dr. Roberto era muito inteligente, esperto, sensível. Acho que ele percebeu que a coisa era com ele e não com a novela. Se alguém pensa que era conivente com os militares, acho que era o contrário, os militares é que eram coniventes com ele. Eles eram parceiros na ideologia. O dr. Roberto tinha pavor da implementação do comunismo no Brasil, não por questões de interesse financeiras, mas ideológicas. Achava que o Brasil tinha que ser um País de economia de mercado. Então ele e os militares rezavam a mesma cartilha. A diferença que havia entre os dois é que o dr. Roberto nunca foi um homem violento. Era essa coisa poliana. Você falava em tortura, ele não acreditava,

\footnotetext{
${ }^{339}$ As cenas citadas são do primeiro capítulo da novela, visto pela autora no acervo da TV Globo, no Rio; todos os outros 35 já gravados foram apagados para que as fitas fossem reaproveitadas; Boni contou em entrevista à autora ter feito um memorando determinando que, por economia, devia-se guardar o primeiro capítulo, alguns do meio e o último, como história, e reaproveitar o restante; as exceções eram apenas para novelas de muito sucesso.
} 
achavam que eram pessoas que queriam salvar o País. Ou fingia que não acreditava. Eles tinham a mesma ideologia, eram parceiros, mas o dr. Roberto nunca foi subserviente. Nesse momento [da censura de "Roque Santeiro"], acho que teve medo de ligar [para o Armando Falcão] e fazer um pedido, porque aquilo ia ser cobrado de maneira muito maior. Então ele engoliu. Em um primeiro momento, botou a culpa em mim, depois percebeu que não era comigo, era com ele, e assumiu a responsabilidade de que aquilo era uma atitude arbitrária da Censura. ${ }^{340}$

Ao mesmo tempo que se preparava o texto-bomba, duas operações de guerra foram armadas. A primeira, com os funcionários de Brasília, para tentar reverter até o último minuto a proibição -seria difícil, acreditavam, mas não impossível, visto que outros vetos haviam sido revogados anteriormente. Ofícios como o assinado pelo diretor-geral da Polícia Federal, de tom mais duro, também costumavam ser utilizados pelo regime a fim de assustar a emissora, que cedia mais facilmente às mudanças exigidas nas obras. Podia ser apenas uma ameaça para intimidar a Globo...

A segunda operação urgente naquela véspera da estreia ficou a cargo de Daniel Filho, que começou a editar um compacto de "Selva de Pedra", novela de Janete Clair exibida entre 1972 e 1973, que chegou a ter episódio com 100\% de audiência. No pior cenário, a reprise ficaria no ar até que uma nova novela fosse produzida para as $20 \mathrm{~h}$.

Marinho convocou o diretor de jornalismo, Armando Nogueira, para ir à sua sala escrever com ele o editorial. Boni achou por bem se certificar de que o empresário sabia que "Roque Santeiro" era uma versão de "O Berço do Herói”. Sim, informantes em Brasília já haviam alertado o empresário. Em uma primeira versão, o editorial escrito por Nogueira era cauteloso, prolixo e colocava panos quentes na situação. À mão, Marinho mudou o texto para que a mensagem ficasse mais clara e direta.

Na noite de 26 de agosto, o último capítulo de "Escalada", de Lauro César Muniz, foi exibido sem que se soubesse o que entraria no ar em seu lugar no dia seguinte. Não foi uma noite fácil, e Boni a passou em claro. Sentia que um certo divórcio havia ocorrido em sua relação com o patrão, e chegou a se questionar: Será que a culpa por aquela situação em que a emissora se encontrava não seria dele? Não

340 Declaração à autora, em 12/9/2011. 
deveria ter previsto que algo assim pudesse acontecer com uma novela de Dias Gomes às $20 \mathrm{~h}$, baseada em uma peça censurada pelos militares? Teria sido ingênuo ${ }^{341}$

Não. A culpa do executivo não tinha razão de ser. Nunca uma telenovela havia sido inteiramente censurada até então, a negociação entre emissoras de TV e governo sempre prevaleceu para esse tipo de programa tão caro a ambos. Um veto drástico, que pudesse prejudicar a emissora financeiramente, não era algo que a própria Censura desejasse. Isso está claro em um livro lançado poucos meses antes por um censor tido como exemplar, que dava cursos para técnicos da Censura na Academia Nacional de Polícia - "Censura \& Liberdade de Expressão", de Coriolano de Loyola Cabral Fagundes, se tornaria uma espécie de manual para os profissio nais da área. O autor fala das novelas de TV em uma passagem na qual faz um alerta para que a cassação de certificado de filmes não seja arbitrária e considere o investimento na produção:

O mesmo se dá com programa em série, gravados em videotape para a televisão, sobre os quais há contratos com patrocinadores, envolvendo vultosíssimas somas, estando já acertando inclusive o horário de transmissão. Será lícito dar ouvidos a meia dúzia de donas de casa frustradas, as quais em cartas e queixam à Censura contra determinada telenovela, e prejudicar financeiramente a empresa produtora, legalmente estabelecida e pagadora de impostos que revertem em benefício da coletividade?

Tampouco é válida a tese de uma censura alheia aos problemas financeiros das empresas produtos de filmes cinematográficos ou outros programas gravados para a televisão. Como órgão do governo federal, que se esforça por propiciar ambiente de estímulo para a iniciativa privada, cujo fortalecimento econômico-financeiro reflete na maior arrecadação de impostos e, consequentemente, em mais meios de promover o bem-estar social, a Censura não pode se constituir num entrave capaz de conduzir à bancarrota essas organizações ${ }^{342}$.

Por isso, todos na emissora tiveram esperança até a última hora. Mas, no dia seguinte, ao menos os dois jornais do grupo Estado já davam como certo que "Roque Santeiro" não iria ao ar. Em "O Estado de S. Paulo", uma nota discreta, com dois

\footnotetext{
341 Todas essas informações sobre a véspera da "não estreia" de "Roque Santeiro" são de entrevista de Boni à autora, pessoalmente, no Rio, em 12/9/2011, com alguns detalhes depois checados por ele com outros funcionários da emissora, enviados por e-mail nos dias posteriores.

342 FAGUNDES, Coriolano de Loyola Cabral. Censura \& liberdade de expressão. São Paulo: Editora Taika, 1974, p. 88-89
} 
parágrafos, tinha como título "Suspensa exibição de novela", e informava que a Globo “decidiu cancelar a exibição (...) devido aos cortes impostos" pela Censura, "que reduziriam cada capítulo a 15 minutos no máximo". "A decisão foi tomada ontem à noite em reunião do elenco e do autor com diretores da emissora", afirmava o texto, encerrado com a informação de que uma comitiva planejava ir à Brasília tentar uma audiência com o presidente Geisel ${ }^{343}$. O "Jornal da Tarde" avançou o sinal. A reportagem abria a página 19 , tinha como título "Um herói impróprio para as $20 \mathrm{~h}$ ", e o subtítulo era "Roque Santeiro enfrenta a censura. E não estreia hoje". O tom era editorializado:

Dias Gomes escreveu uma novela para ir ao ar às $20 \mathrm{~h}$. Por isso, não carregou no sexo, na violência, nem nos conflitos entre pais e filhos. Também evitou qualquer conotação política. Mas a Censura Federal parece ter visto Roque Santeiro com outros olhos e só liberou a novela para as $22 \mathrm{~h} .{ }^{344}$

A reportagem falava em clima de "velório" nos bastidores e trazia declaração de Dias Gomes contra a censura: "Os problemas que isso tudo vem trazendo à televisão são imensos". O autor afirmava ainda que "Roque Santeiro" era a novela "mais leve" já escrita por ele, afirmação da qual a reportagem, apesar de contrária à censura, discordava, dizendo não ser essa a impressão do resumo publicado no boletim da Globo, que transcrevia:

A história de uma homem consagrado como herói e em torno do qual gira a vida de toda uma cidade. A novela traz como proposta a discussão da necessidade de mitos em determinados momentos históricos. Particulariza o caso da fictícia cidade de Asa Branca onde, há dezessete anos, Roque Santeiro, um jovem sem maiores perspectivas, foi transformado em herói ao salvar a população de um ataque de cangaceiros, o que lhe valeu a glória e a morte. ${ }^{345}$

\footnotetext{
${ }^{343}$ Suspensa exibição de novela. O Estado de S. Paulo, 27/8/1975 [matéria não assinada]

${ }^{344}$ Um herói impróprio para as $20 \mathrm{~h}$. "Roque Santeiro" enfrenta a censura. E não estreia hoje. Jornal da Tarde, 27/8/1975, p. 19 [matéria não assinada]

345 Ibidem
} 
O "JT" também informava que a "Globo deve divulgar uma nota hoje", mas ninguém imaginava que a tal nota seria um editorial lido por Cid Moreira no "Jornal Nacional". Às 17h, a Globo teve uma resposta definitiva de seus "assessores militares": Nada feito. Naquele momento, há havia 36 capítulos completamente finalizados e 51 escritos. Iam todos para a gaveta. Cancelar uma novela cujas chamadas já estavam no ar era, para a Globo, como quebrar a palavra diante dos telespectadores e dos anunciantes. No dizer de Boni, "aquilo desmoralizava nossas competências"346. Algo impensável para o Padrão Globo de Qualidade. Ideologias à parte, era uma questão estratégica naquele momento deixar claro que a culpa era do governo.

Após a última notícia do "Jornal Nacional" daquele 27 de agosto de 1975, entrou no ar a abertura de "A Fabulosa Estória de Roque Santeiro e de sua Fogosa Viúva, a que Era sem Nunca Ter Sido". Os arranjos especiais eram de Dori Caymmi (o jovem que aos 20 anos havia participado da produção musical de "O Berço do Herói’) e a sonoplastia, de Antônio Faya. A coordenação musical tinha a assinatura de João Araújo e a produção, de Nelson Motta. O produtor havia elaborado a trilha completa da novela, com músicas especialmente compostas para cada personagem, todos mostrados a ele por Daniel Filho. Foi grande a sua frustração ao saber que o público veria apenas a abertura, e apenas uma vez ${ }^{347}$.

Uma sequência de xilogravuras do artista J. Borges ia passando ao som de um baião que começava assim: "Quem sabe não quer falar / quem fala não quer dizer / Eu vou mostrar pra vocês / a história que o povo conta / É história feita de fé, de ambição e de glória / é história dentro da história, é favor prestar atenção"348.

Após a abertura, em vez de os personagens aparecerem, o locutor do "JN", Cid Moreira, voltou à tela. Por cerca de dois minutos, leu o editorial em que a Globo assumia pela primeira vez, desde o golpe, discordância com os militares. Sabia exatamente o significado daquela locução e estava tenso. Por orientação do "dr. Roberto", usou um tom sóbrio, mas não tão forte. O texto já tinha força suficiente ${ }^{349}$.

\footnotetext{
346 Entrevista de Boni à autora.

347 Entrevista de Nelson Motta à autora em setembro de 2011.

${ }^{348}$ A abertura e a íntegra do primeiro capítulo foram vistos pela autora no arquivo da TV Globo. Há no YouTube um trecho da abertura.

${ }^{349}$ Entrevis ta de Cid Moreira à autora em setembro de 2011.
} 
Desde janeiro que a novela "Roque Santeiro" vem sendo feita. Seria a primeira novela colorida do horário das oito da noite. Antecipando-se aos prazos legais, a Rede Globo entregou à Censura Federal o script dos 20 capítulos. No dia 4 de julho, finalmente, o diretor de Censura de Diversões Públicas, Sr. Rogério Nunes, comunicava à Rede Globo: os vinte primeiros capítulos estavam aprovados para o horário das oito "condicionados porém dizia o ofício- à verificação das gravações para obtenção do certificado liberatório". O mesmo ofício apontava expressamente os cortes que deviam ser feitos e recomendava que os capítulos seguintes, a partir dos 20 já examinados, deviam manter -palavras textuais da Censura- "o mesmo nível apresentado até agora". Todos os cortes determinados foram feitos.

A Rede Globo empregou todos os seus recursos técnicos e pessoais na produção da novela "Roque Santeiro". Contratou artistas, contratou diretores, contratou cenógrafos, maquiladores, montou uma cidade em Barra de Guaratiba, enfim, a Globo mobilizou um grandioso conjunto de valores que hoje é necessário à realização de uma novela no padrão da Globo. Foram mais de 500 horas de gravação, das quais resultaram os 20 primeiros capítulos, devidamente submetidos à Censura.

Depois de examinar devidamente os capítulos gravados, o Departamento de Censura decidiu: a novela estava liberada, mas só para depois das dez da noite. Assimmesmo, com novos cortes. Cortes que desfigurariam completamente a novela.

Assim, a Rede Globo, que até o último momento tentou vencer todas as dificuldades, vê-se forçada a cancelar a novela "Roque Santeiro". No lugar de "Roque Santeiro", entra em reapres entação, e em capítulos concentrados, a novela "Selva de Pedra", com Regina Duarte e Francisco Cuoco. Dentro de alguns dias, porém, -esse é um compromis so que assumimos com o público, a Rede Globo estará com uma nova novela para o horário das oito. Para isso começou hoje mesmo a mobilização de todo o nosso patrimônio: o elenco de artistas, os técnicos, os produtores, enfim, todos os profissionais que aqui trabalham com o ânimo de apurar cada vez mais a qualidade da televisão brasileira.

Foi desse ideal de qualidade que nasceu a novela "Roque Santeiro" e é precisamente com esse mesmo ideal que, dentro de alguns dias, a Globo estará apresentando no horário das oito da noite uma novela -esperamos-de nível artístico ainda melhor que "Roque Santeiro". 350

350 Íntegra do editorial publicada pelo jornal “O Globo” em 28/8/1975. 
Apesar do tradicional "Boa noite" de Cid Moreira, naquele 27 de agosto de 1975 os telespectadores despertaram para o pesadelo da censura. 


\subsection{Capítulo 9}

\section{Despertar lento e gradual}

Dias Gomes assistiu ao editorial na sala de Walter Clark, e a expectativa era a de que o canal seria cassado. O executivo passou 20 minutos colado ao telefone, em diversos contatos com os representantes da Globo em Brasília, até ouvir que essa hipótese da cassação estava descartada ${ }^{351}$.

Boni acompanhou a leitura do texto por Cid Moreira em sua sala, ao lado do diretor Daniel Filho, e os dois caíram em $\operatorname{prantos}^{352}$. O chamado "todo-poderoso" da Globo passou mal -sentiu uma forte dor de cabeça e pensou estar tendo um derrame. Levado à clínica São Vicente, foi medicado com calmantes e apagou. Às 6h estava acordado e agoniado para receber alta. Como o médico não aparecia, trocou de roupa e "fugiu" da clínica, direto para a emissora. Claro que não encontrou ninguém no local àquela hora da manhã. Estava desesperado para saber o Ibope da noite anterior, o tamanho do prejuízo. Os números só chegavam às $11 \mathrm{~h}$. Bem antes disso, ligou para Paulo Montenegro, executivo do Ibope: "Manda alguém somar essa porcaria logo". Às 10:30, teve a resposta: a audiência havia sido "um espetáculo". Também foi animador o resultado de uma enquete que solicitara a Homero Icaza Sánchez, diretor do Departamento de Análises e Pesquisas da emissora. Dos telespectadores consultados por telefone, $71 \%$ haviam assistido ao editorial, com 100\% de aprovação, e 65\% afirmaram que iriam acompanhar a reprise compacta de "Selva de Pedra". O primeiro capítulo da novela, exibido na íntegra, deu $41 \%$ de audiência -o segundo, já em versão compactada, iria subir para $47 \%-$, sendo que o último capítulo de "Escalada" havia registrado $56 \%{ }^{353}$. A direção comemorou, conforme Boni: "Quando descobrimos que 'Selva de Pedra' estava dando uma audiência melhor do que a que esperávamos de 'Roque Santeiro', relaxamos".

Definitivamente, a consequência da censura para a Globo estava longe da "bancarrota", como temia o manual do censor Coriolano. No saldo, a perda maior parece ter ficado com o governo. Não bastasse o editorial lido no mais prestigiado

\footnotetext{
351 GOMES, Dias. Apenas um subversivo. Rio de Janeiro: Bertrand Brasil, 1998, p. 284

352 Informação dada por Daniel Filho ao Projeto Memória Globo, disponível em robertomarinho.com.br.

${ }^{353}$ Informações da entrevis ta de Boni à autora; os dados do Ibope e do levantamento da Globo estão em $\mathbf{O}$

fim de "Roque". Veja, 3/09/1975, ed. 365, p. 17 [matéria não assinada].
} 
telejornal nacional, Marinho determinou que se publicasse sua íntegra no jornal "O Globo" do dia seguinte. O título era lacônico: "Roque Santeiro". Nesse primeiro momento, entretanto, talvez por estarem desavisados, talvez por ceticismo em relação ao enfrentamento da Globo ao governo ou quem sabe por temor, outros jornais entraram discretamente no assunto e evitaram qualificar o ocorrido na noite anterior como censura. Na "Folha de S.Paulo", uma reportagem pequena, no canto de uma página da "Ilustrada" tinha como título "Globo decide não exibir "Roque Santeiro"”. O primeiro parágrafo era pouco esclarecedor - dá uma pista do quão confusa a situação soava- e, assim como a manchete, colocava a carga do cancelamento na emissora:

Embora se comentasse ontem à noite na sede da TV Globo, [sic] que a Censura Federal teria voltado atrás em sua decisão de permitir a ida ao ar da novela "Roque Santeiro" sem cortes, cancelando sua decisão anterior que liberava o espetáculo para as $22 \mathrm{~h}$ bastante cortado, a direção da empresa anunciou, em nota oficial, que não mais exibiria a novela. ${ }^{354}$

"O Estado de S. Paulo" trazia uma nota ainda menor, no pé da página, e mais favorável ao governo, sob o título "Novela é liberada mas TV a cancela". Eram apenas dois parágrafos, e o primeiro continha erro de informação ao dizer que a novela, "proibida anteontem pela Censura para exibição às 20 horas, foi ontem liberada sem cortes mas para apresentação às 22 horas", o que "não foi aceito pela TV Globo, que ontem à noite anunciou ter cancelado a exibição" ${ }^{355}$. Do mesmo grupo, mas com postura mais ousada principalmente por ser voltado a um público mais jovem, o "Jornal da Tarde” abriu uma de suas páginas culturais com letras maiúsculas: “ROQUE SANTEIRO', CAPÍTULO II"356. Acima de uma foto de Daniel Filho, um subtítulo dizia “No Rio, um dia agitado. Com discussões e choro de Daniel”. A matéria, com dez parágrafos, dava destaque à decisão tomada por parte do elenco de viajar a Brasília a fim de tentar um encontro com o presidente Geisel para falar sobre censura. Daniel Filho "desabafava": "Que importância tem o artista brasileiro em seu próprio País, já que somos artigo supérfluo e podemos ser extintos a qualquer hora?” Afirmava que o

\footnotetext{
354 Globo decide não exibir "Roque Santeiro". Folha de S.Paulo, 28/8/1975, p. 48 [matéria não assinada]

355 Novela é liberada mas TV a cancela. O Estado de S. Paulo, 28/8/1975 [matéria não assinada]

356 "Roque Santeiro", capítulo II. Jornal da Tarde, 28/8/1975 [matéria não assinada]
} 
prejuízo financeiro da emissora havia sido de Cr\$1,5 milhão, com 51 capítulos já escritos por Dias Gomes e 30 gravados (na verdade, foram 36), além da manutenção de um elenco com 40 atores, além de centenas de figurantes. O autor afirmava que os cortes haviam sido "incoerentes", pois não se referiam aos assuntos mais visados, "como adultério, conflito entre pais e filhos, choque de classes, tóxico e sexo". Abaixo do texto sobre "Roque Santeiro", outras três notícias estavam sob o chapéu "Censura". A primeira falava do fato de o Supremo Tribunal Federal ter julgado "insuscetível de apreciação judicial a censura prévia de qualquer publicação literária ou artística”. A segunda notícia dava conta de que o ministro da Justiça, Armando Falcão, havia se recusado a comparecer a um debate na Câmara sobre censura, atitude pela qual estava sendo criticado. A terceira falava da apreensão de um catálogo do artista plástico Pierre Chalita por apresentar na capa uma figura erótica.

O "JT", contudo, era um jornal menor, e a direção da Globo considerou que nesse primeiro dia não houve grande repercussão. Possivelmente, avaliou Boni, os jornais não queriam colocar a Globo como mártir. "Tinha muita gente achando engraçado, pensando: 'Bem feito para eles, bem feito!'”357 O impacto, contudo, seria bombástico quando as estrelas da TV resolveram pegar um avião para bater à porta do presidente. A decisão havia sido tomada na véspera em uma reunião da qual Dias Gomes também participara e falara sobre a possibilidade de a censura ter a ver com " $\mathrm{O}$ Berço do Herói”".

Na manhã pós editorial, 23 profissionais do primeiro time da Globo -entre eles Regina Duarte, Francisco Cuoco, Tarcísio Meira, Lima Duarte e Lauro César Muniz ${ }^{358}$ viajaram a Brasília para entregar um manifesto ao presidente, em um ato que certamente seria o mais midiático contra a censura desde o golpe. Às $11 \mathrm{~h}$, o grupo já estava no Palácio do Planalto, mas a recepção foi frustrante. Nada de Geisel, quem thes recebeu foi o subchefe da Casa Civil, Alberto de Eduardo Costa, que confessou estar diante de uma "situação desagradável". Todos falavam ao mesmo tempo. Lima Duarte mencionou a "preocupação cultural pelos efeitos da censura", Paulo Gracindo, a "castração das obras", e Carlos Eduardo Dolabella disse que eles não queriam falar com o ministro da

\footnotetext{
357 Entrevista de Boni à autora.

${ }^{358}$ A lista completa da comitiva saiu em reportagem do "Jornal da Tarde" de 29/08/1975: Regina Duarte, Beth Mendes, Betty Faria, Cláudio Marzo, Dennis Carvalho, Aracy Balabanian, Ziembisnsky, Tarcísio Meira, Débora Duarte, Glória Menezes, Paulo Gracindo, Ioná Magalhães, Lima Duarte, Dan iel Filho, Elza Gomes, Armando Bogus, Eva Tudor, Milton Gonçalves, Carlos Eduardo Dolabella, Luis Armando Queiroz, Lauro César Muniz e Francisco Cuoco.
} 
Justiça porque "censura não é caso de polícia". Pela janela, o funcionário público mostrou um helicóptero que estaria levando o presidente Geisel a compromissos.

Gracindo então leu a carta em voz alta, diante de repórteres, fotógrafos e câmeras de televisão. O texto havia sido elaborado pelo dramaturgo Paulo Pontes, um dos vários membros do Partido Comunista contratados pela Globo. Eis a íntegra:

Exmo. Sr. Presidente da República, general Ernesto Geisel,

Como artistas de televisão, teatro e cinema, tomamos a liberdade de vir aqui neste momento, movidos pela necessidade inadiável de exprimir a V. Exa. a nossa apreensão diante dos crescentes obstáculos que estamos enfrentando para o exercício da nossa atividade profissional.

Conhecemos as preocupações de V. Exa. em relação aos destinos da nossa cultura. Elas foram manifestadas em várias oportunidades, inclusive em encontro com colegas nossos em Manaus. Por isso, não pretendemos repetir o que têm sido as dificuldades destes últimos anos para a produção cultural no Brasil. As consequências são evidentes: a ação excessivamente rigorosa da censura tem empobrecido a qualidade do nosso produto cultural, estreitado o nosso mercado de trabalho e descaracterizando as nossas obras .

O País vive uma triste contradição: enquanto a sociedade se moderniza, a cultura, por efeito de um código de censura anacrônico e implacável, se avilta, se desfigura e se desnacionaliza.

Não se pode negar ao artista e criador brasileiro de hoje moderação e bom senso na aceitação dos limites cada vez mais estreitos impostos ao trabalho cultural. No entanto, o exemplo mais recente dessa situação ag ravou a nossa intranquilidade, sobretudo porque não é um exemplo isolado. Um produção de televisão envolvendo 500 profissionais, entre atores, técnicos e figurantes, teve que ser suspensa depois de dezenas de capítulos gravados e de anunciada em todo o País. Os cortes impostos à obra foram de tal ordem e em tamanha extensão que se tornou impossível sua transmissão. No momento em que o governo declaradamente se preocupa com a invasão de valores alienígenas e com a elevação do nível cultural das programações de televisão, 30 milhões de expectadores ficarão privados de assistira uma produção brasileira, com tema e ambiente brasileiros, escrita por um autor reconhecido unanimemente como um dos renovadores da narrativa teatral no Brasil.

Há, sr. presidente, uma visão distorcida de nossa atividade, que nos procura situar como uma categoria social à parte. Na verdade, numa sociedade complexa como a do Brasil de hoje, somos os responsáveis por uma diversificada indústria de diversões e produção cultural. Produzimos por 
ano, no eixo Rio-São Paulo, cerca de 300 espetáculos profissionais ao vivo, uma média de 100 filmes de longa-metragem, dezenas de novelas, shows e noticiários na televisão. É um conjunto de atividades que envolve grandes investimentos, trabalho, responsabilidades sociais. É da natureza dessa atividade sentir os impasses e as vicissitudes da sociedade e recriá-los através dos nossos instrumentos de expressão -a televisão, o palco, o rádio, o jornal, o disco, o livro etc. Sem o mínimo de liberdade, sr. Presidente, o que está em risco é a nossa sobrevivência profissional.

Sabemos que nos últimos cinco anos foram proibidas mais peças do que em toda a história republicana; sabemos que filmes, jornais, revistas, discos, livros continuam sofrendo cortes que desfiguram irremediavelmente seu sentido original; sabemos que a autocensura é o ânimo predominante no meio dos criadores e artistas.

Mas agora, diante desse medida de gravidade sem precedentes, que ameaça a atividade de 500 profissionais e destróiuma obra já previamente liberada para a TV, de um dos autores brasileiros mais representativos, não nos resta outra alternativa senão confessara V. Exa.: sr. Presidente, com perplexidade e apreensão manifestamos a nossa preocupação pelos destinos da cultura brasileira.

Respeitosamente ${ }^{359}$.

Após a leitura, o subchefe da Casa Civil pediu que a carta fosse deixada com ele para ser entregue ao presidente. Os artistas resolveram não sair dali enquanto não fossem recebidos por alguém do alto escalão. Pressionado com a presença de tantas grifes e com a cobertura da imprensa, o governo achou melhor resolver logo o impasse e em 15 minutos o grupo foi informado de que Golbery receberia um -e apenas umrepresentante da comitiva. Daniel Filho, escolhido para a missão, foi avisado de que o general daria a ele apenas três minutos. Calculou que não daria tempo de ler a carta, o que também achou que poderia soar ridículo, ficar plantado em frente ao general declamando o texto... Foi recebido de pé pelo homem que era um dos principais articuladores do regime militar. Entregou-lhe a carta, pedindo que a encaminhasse a Geisel e explicando que se tratava de um manifesto contra a censura. Golbery pegou o papel, colocou em cima da mesa respondendo que seria entregue. Os três minutos duraram uma eternidade, tão tenso estava o clima. Até que eles se despediram, e Daniel

\footnotetext{
359 A íntegra está publicada em reportagem do "Jornal da Tarde" de 29/08/1975; as informações sobre a comitiva são da mesma matéria e de FILHO, Daniel. Antes que me esqueçam. Rio de Janeiro: Editora Guanabara, $3^{\mathrm{a}}$ edição, 1988, p. 177-180.
} 
voltou frustrado ao encontro dos outros globais. Na saída, o ator Cláudio Marzo foi fotografado com o polegar para baixo, anunciando como negativo o resultado. A sensação naquele instante era de viagem perdida. Sensação completamente equivocada.

O impacto midiático era imprevisível quando até a namoradinha do Brasil batia à porta do Planalto para reclamar. A fim de reduzir danos, uma nota da Censura foi divulgada. Não era usual que eles se dessem ao trabalho de se explicar -matéria do "JT" falava que a atitude era uma "surpresa", uma mudança de hábito-, mas a história da saga do falso herói se repetia, pois, dez anos antes, diante da repercussão da proibição de "O Berço do Herói”, os censores também se viram obrigados a se justificar publicamente. A nota foi elaborada em reunião entre o ministro da Justiça, Armando Falcão, e o diretor do Departamento da Polícia Federal, Moacyr Coelho, que assinara o oficio vetando a novela para as $20 \mathrm{~h}$. O texto resumia o passo-a-passo de ofícios e dizia que a proibição se dava por "ofensa à moral, aos bons costumes, bem como achincalhe à Igreja".

O caso reverberou na Câmara, onde o manifesto dos artistas foi lido, e se decidiu pela criação de um grupo de trabalho para a elaboração de um nova legislação de censura. Deu-se extensivo debate entre deputados sobre "Roque Santeiro", com críticas e elogios à sua proibição. Mais do que a discussão entre os parlamentares, contudo, o impacto do veto e da comitiva global em Brasília levaram a censura para a boca do povo com uma intensidade inédita na ditadura. Como bem resumiu o texto-legenda da ampla fotografia do grupo de atores publicada no dia seguinte em reportagem que ocupou uma página inteira no "Jornal da Tarde", sob o título todo em letras maiúsculas, "A TEVE ENCENA UM GRANDE SUCESSO: A CENSURA":

Os artistas mais populares do País - como Regina Duarte, Francisco Cuoco, Paulo Gracindo, Glória Menezes, Tarcísio Meira, Ioná Magalhães e Lima Duarte- com a colaboração da emissora de maior audiência, a TV Globo, transformaram um rotineira decisão da Censura Federal no maior sucesso do ano. Nenhuma novela conseguiu despertar tanto interesse e provocar tantas discussões como a obrigatoriamente inédita "Roque Santeiro". E nenhum episódio fez com que as tensas relações entre as artes e a Censura se transformass em no as sunto obrigatório das discussões populares, das salas de jantar aos botequins. Mais do que is to, a proibição da novela estabeleceu uma harmoniosa unidade de protestos [grifo nosso]. 
contestadas coma mesma franqueza na Câmara dos Deputados, na Associação Brasileira de Imprensa e em reuniões de artistas e intelectuais. ${ }^{360}$

O ponto grifado, sobre o fato de a censura à "Roque Santeiro" ter estabelecido "harmoniosa unidade de protestos", revela a maneira que esse tipo de cerceamento cultural, como um remédio, muitas vezes pode trazer efeitos colaterais similares ao "mal" que pretende evitar. Porque nesse período pós AI-5 até 1978, considerado como o segundo momento da repressão à cultura na ditadura, o objeto do regime era justamente "reprimir o movimento da cultura como mobilizadora do radicalismo da classe média (principalmente estudantes)".

Ness a fase o regime se armou com novas leis, como a nova Lei da Censura, em novembro de 1968, que sistematizava a censura sobre obras teatrais e cinematográficas e criava o Conselho Superior de Censura, implantado efetivamente somente em 1979. O decreto-lei $n^{\circ} 1.077$, de janeiro de 1970, instaurou a censura prévia sobre materiais impressos. A Polícia Federal, a partir de 1972, se reorganizou para aplicar a censura com mais eficiência, cm a criação da Divisão de Censura de Diversões Públicas e a ampliação do seu corpo de censores. Para controlar a imprensa, havia os "bilhetinhos" que saíam do Serviço de Informação ao Gabinete do Ministro da Justiça (Sigab/MJ, criado em 1971) e a autocensura nas redações de periódicos da grande imprensa. ${ }^{361}$

Obviamente, não foi a censura a "Roque Santeiro" que estabeleceu a "união harmoniosa de protestos", como afirmou o "Jornal da Tarde". Ao menos não exclusivamente. Ela jogou, sim, holofotes e certamente reforçou algo que acontecia no País desde 1974, quando, na explicação do historiador Marcos Napolitano, "esboçou-se uma grande frente oposicionista formada por empresários, políticos liberais, políticos de esquerda, movimentos sociais, movimento estudantil". "Mesmo as organizações armadas de esquerda fizeram sua autocrítica e assumiram a 'questão democrática' como sua plataforma". Esse contexto de unificação e tomada de consciência da classe média contra o poder ditatorial explica também, para além da irritação de Roberto Marinho, a

\footnotetext{
360 A tevê encena um grande sucesso: a censura. Jornal da Tarde, 29/8/1975 [matéria não assinada] 361 NAPOLITANO, Marcos. 1964 - His tória do regime militar brasileiro. São Paulo: Contexto, 2014, p. 100
} 
decisão da Globo de colocar o editorial no ar -nessa segunda metade dos anos 1970, as empresas jornalísticas passariam a questionar mais abertamente a censura.

Essa força oposicionista assustou a ditadura, que foi obrigada a adotar o discurso da "abertura" a fim de mascarar a política mais rigorosa de repressão:

Este segundo momento repressivo conviveu com o auge da política cultural proativa, expressada pela Política Nacional de Cultura, ambicioso plano que combinava mecenato oficial e normatização do campo cultural e suas instituições públicas, lançado em 1975 pelo MEC, dentro da estratégia da institucionalização do regime, conhecida genericamente como "abertura". 362

Dessa forma, o ano de 1975, quando se deu o veto a "Roque Santeiro", foi especialmente nebuloso sobre o que podia e não podia no Brasil -um reflexo direto da crise em que se encontrava o governo. A censura prévia às telenovelas havia sido incluída na legislação em 21 de novembro de 1968, menos de um mês antes da decretação do AI-5. No lugar do teatro, foco do primeiro período de repressão, a TV se mostrava mais "perigosa" nesse segundo momento, mesmo para o censor da linha mais "liberal" Coriolano, que no livro de 1974, com pretensões de manual para a censura, escrevera, sob o intertítulo "Maior ou menor rigor":

O censor deve levar em conta as características do veículo pelo qual se apresentará o espetáculo, com vistas no rigor do critério do julgamento. Entendemos estarem em escala ascendente os seguintes entretenimento, dentre os principais meios de comunicação:

a) Teatros e congêneres - o censor deve sermais condescendente com espetáculos de placo em geral, porque não é um público qualquer o que lhes tem acesso. O elevador preço do ingresso, nesse setor,já é fator de seleção da plateia;

b) O cinema - neste campo o censor já pode ser um pouco menos liberal ao julgar, porque o cinema é a diversão popular por excelência;

c) Televisão - os programas de televisão são os que devem ser julgados mais rigorosamente, especialmente tendo em vista que a programação das emissoras não deixa praticamente margem

362 Ibidem, p. 101 
alguma de escolha para o espectador, além da dificuldade que se tem de evitar sejam os espetáculos de mensagens prejudiciais mostrados para jovens. ${ }^{363}$

Para Coriolano, a TV e o rádio representavam "preponderantes papéis no sentido da educação ou deseducação populares" e constituíam "poderosíssima arma de doutrinação política, que pode desacreditar qualquer líder ou forma de governo, da noite para o dia". Ele lembrava ainda que as organizações de radiodifusão tinham "significativo poderio econômico" e "grande influência política", razões pelas quais se tornava "bastante dificil a ação coercitiva do órgão censório nesse setor".

Pensamento semelhante tinha o ministro da Justiça, Armando Falcão, para quem “a televisão e o rádio são duas forças psicológicas de tamanha e tão instantânea influência que não é possível admitir que o poder público olhe para os dois com indiferença e passividade" ${ }^{364}$. Se ele admitiria em sua autobiografia, escrita já no período democrático, em 1989, que para imprensa escrita, livros, teatro e cinema "vá lá, a liberdade ampla é tolerável", para o veículo que "penetra escancaradamente nos lares, no recesso sagrado da família -aí, não!- há que haver controle, há que haver censura”. Porque, "se não houver", questiona, "como defender a pureza na formação da alma da criança, como cimentar a crenças nos bons princípios e no espírito do adolescente?"365 Conhecido como o ministro da expressão "nada a declarar", não abordaria especificamente o caso "Roque Santeiro" em seu livro de memórias, mas admitiria que as telenovelas the "criaram problemas na área da censura" e que foi "forçado a usar a tesoura com largueza". "É que todos os autores de novela são marxistas disfarçados ou assumidos, que utilizam indevidamente a novela para infiltrar a propaganda de suas ideias, de modo ostensivo ou subliminar", escreveria ${ }^{366}$.

A imprensa, com o relativo respiro dado após a saída, naquele ano de 1975, de censores do governo das Redações, entrou abertamente na cobertura da censura à "Roque Santeiro" no segundo dia, publicando reportagens sobre a comitiva global. O material de uma página do "Jornal da Tarde" trazia cinco textos, um deles dedicado à discussão gerada pelo veto à novela na Associação Brasileira de Imprensa sobre a

\footnotetext{
${ }^{363}$ FAGUNDES, Coriolano de Loyola Cabral. Censura \& liberdade de expressão. São Paulo: Editora Taika, 1974, p. 153

${ }^{364}$ FALCÃO, Armando. Tudo a declarar. São Paulo: Nova Fronteira, 1989, p. 354

365 Ibidem

366 Ibidem, p. 374-375
} 
censura em geral, e especificamente em relação aos jornais. A "Folha", em contraste com o laconismo da véspera, dava chamada na primeira página (“O 'Santeiro' leva artistas ao Presidente" ${ }^{367}$ ) e reportagem com duas colunas do alto até o pé da página, ilustrada por foto da comitiva e trazendo a íntegra do manifesto e da nota do Censura ${ }^{368}$.

No quarto dia depois da não estreia, em 31 de agosto, entrou em cena o tom mais opinativo. Na coluna "O Jornal dos Jornais" (“Folha”), espécie de precursora do papel de ombudsman (que o jornal criaria em 1989), Alberto Dines dizia que o clima de "frenesi censório" do momento se assemelhava ao do AI-5, mas que "Roque Santeiro" teve o "mérito" de fazer com que o tema da censura, restrito à elite intelectual, ganhasse repercussão nacional. O título da coluna daquele dia foi "Ascensão e milagres de 'Roque Santeiro"'.

As 5 mil pessoas que se importavam e sofriam com a censura no Brasil multiplicaram-se da noite para o dia e converteram-se em 20 milhões. Onde há um aparelho de TV no Brasil há gente irritada com as autoridades que lhes surrupiaram o espetáculo e o entretenimento.

Um dos escopos e razões da censura é atuar sob disfarce, subrepticiamente, sem mostrar-se. É por esta razão que os regimes autoritários preferem sempre a autocensura e a colaboração do censurado. Só as sim leitores e espectadores engoleme aceitam as informações que lhes são oferecidas. Mas quando a censura se desvenda, como aconteceu agora, fica evidente para a população brasileira que ela existe para roubar-lhe alguns momentos de bem-estar (...) A censura virou coisa pública, vedete. (...)

Artistas, intelectuais e técnicos quas e sempre foram favoráveis à estatização da televisão brasileira. Hoje, são eles que estão apontando a proibição de "Roque Santeiro" como a primeira incursão estadista na área da TV. $\underline{\text { O governo conseguiu, de uma penada só, esta façanha de unir }}$ empresários e profissionais numa frente única [grifo nosso]. ${ }^{369}$

Com o tempo se mostraria romântica a ideia de que a sociedade é contrária à censura -o cerceamento à liberdade de expressão sobrevive em regimes democráticos justamente porque tem suporte de parcela dos cidadãos. Mas Dines apontava para a

\footnotetext{
367 O "Santeiro" leva artistas ao presidente. Folha de S.Paulo, 29/8/1975, p. 1 [chamada não assinada] 368 Protestos de artistas contra a proibição. Folha de S.Paulo, 29/8/1975, p. 40 [matéria não assinada] 369 DINES, Alberto. Ascenção e milagres de "Roque Santeiro" - "O Jornal dos Jornais". Folha de S.Paulo, 31/8/1975, p. 6
} 
questão central levantada por Napolitano sobre a repressão à cultura: a sua capacidade, desde o início da ditadura, ter colocado esquerda e liberais em torno de um interesse unificado, a favor da liberdade de expressão. $O$ jornalista segue com elogio à postura da Globo, que fez, segundo ele, um "protesto calmo e firme" com a divulgação do editorial, um "ato de coragem que obrigou as autoridades a explicar-se, o que é raro" e, assim, "impôs às autoridades o jogo democrático" -palavras fortemente contrárias à visão esquerdista da Globo como TV oficial da ditadura. Aponta por fim para o fato de o veto ter evidenciado o conflito entre a Igreja e o governo (principalmente em razão dos direitos humanos) -na véspera, o presidente da CNBB (Conferência Nacional dos Bispos do Brasil) declarara que a instituição não tivera contato com os censores para falar sobre a novela, uma forma de deixar transparecer que não estava assinando embaixo da proibição por "achincalhar a Igreja". Desse modo, trouxe à tona o quão encurralada estava a ditadura. “'Roque Santeiro' fez um novo milagre. Transformou um mito do Nordeste em herói nacional", resumiu Dines.

$\mathrm{O}$ assunto seguiu diariamente nos jornais, com repercussões na política e entrevistas com o elenco. Nem tudo eram flores nessa onda anticensura. O diretor da Central Globo de Comunicação, João Carlos Magaldi, foi demitido por Roberto Marinho por ter distribuído o boletim de imprensa daquela semana com a capa em branco, onde se lia apenas a palavra "SILÊNCIO" - a demissão foi revogada após o apelo de Boni ${ }^{370}$. O próprio jornal "O Globo", depois da publicação do editorial, fez uma discreta cobertura, assim como outros jornais cariocas, o que Dias Gomes criticou publicamente em uma reportagem de uma página da "Folha de S.Paulo", uma semana após a censura ${ }^{371}$. O "Jornal da Tarde", que nas páginas de reportagem dera amplo espaço ao caso, sempre com tom contrário à repressão, quase um mês depois, em $23 \mathrm{e}$ 24 de setembro, publicou dois artigos do conservador Lenildo Tabosa Pessoa defendendo a censura e dizendo que, se os autores queriam levar ao ar, via Embratel, "ofensas à moral, à ordem pública e aos bons costumes", além do "achincalhe à igreja", que ao menos fizessem isso após as $22 \mathrm{~h}$-à tarde e antes desse horário, ironizou, “a juventude pode corromper-se nos cinemas" ${ }^{\prime 372}$.

\footnotetext{
370 Para a demissão de Magaldi, GOMES, Dias. Apenas um subversivo. Rio de Janeiro: Bertrand Brasil, 1998, p. 282.

${ }^{371}$ LAGO, Graça. As razões de "Roque Santeiro" por Dias Gomes. Folha de S.Paulo, São Paulo, 5/09/1975, p. 40

372 PESSOA, Lenildo Pacheco. Uma questão de horário - I e Uma questão de horário - II. Jornal da Tarde, São Paulo, 23 e 24/9/1975
} 
Na busca por uma razão mais sólida para essa decisão drástica da censura, um jornalista de "O Estado de S. Paulo" (Paulo Maia), escreveu longo artigo, em 9 de setembro, levantando a hipótese de ter sido um "golpe de marketing" da Globo para gerar curiosidade do público e posteriormente exibir o "fruto proibido"373. Em sua teoria conspiratória, levantava algo real: a sustentação da sociedade para vetos a "questões morais". Falava da rejeição da classe média "ao liberalismo conjugal" da novela "Escalada". Quem sabe a Globo, devaneava o jornalista, com o cancelamento, não estaria evitando colocar algo novamente ousado no ar e assustar o público? E, por isso, em conchavo com o governo, resolvera voltar a dar a "dose diária de açúcar com a novelinha da Janete Clair", garantindo o Ibope...

Ele foi longe demais, mas a verdade é que ninguém engolia a "ofensa a moral etc. etc." como verdadeira razão para o veto. Afinal, tantas outras novelas de Dias Gomes e de outros autores da brasilidade revolucionária traziam elementos censuráveis de sobra. Como lembra Nahuel Ribke, professor da Universidade de Tel Aviv que pesquisa a censura à TV brasileira na ditadura, várias telenovelas anteriores haviam sido liberadas com uma dose de crítica muito maior ${ }^{374}$. Havia diferença entre Sinhozinho Malta e Odorico Paraguaçu? Não. Ambos denunciavam o coronelismo e o utilizavam como metáfora da própria ditadura -e, enquanto Sinhozinho era um fazendeiro, o protagonista de "O Bem-Amado" tinha ainda o "agravante" de ser um político, o prefeito da cidade, tornando mais clara a crítica ao poder. Então por que "O BemAmado" havia ido ao ar com dois terços dos capítulos sem cortes, enquanto "Roque Santeiro" não conseguiu estrear?

A edição da "Veja" da semana da censura, que dedicou duas páginas ao assunto, muito discretamente aventou que o enredo seria uma adaptação de “O Berço do Herói”, “do mesmo Dias Gomes que escreveu 'Roque Santeiro', e que está proibida desde 1965’375. Mas isso não era suficiente para explicar. Havia inequivocamente uma questão politica mais profunda, como disse Roberto Marinho, quando deixou claro saber que a viagem dos artistas a Brasília não iria liberar a novela, porque não estava em questão

\footnotetext{
373 MAIA, Paulo. "Roque Santeiro", um epis ódio que deixa margem a dúvidas. O Estado de S. Paulo, 9/9/1975

${ }^{374}$ RIBKE, Nahuel. Decoding television censorship during the last brazilian military regime - The censor as negotiator and censorship as a semi-open interpretative process. Media History, 2011, vol. 17, n. 1.201

375 O fim de "Roque". Veja, ed. 365, 3/9/1975, p. 17-18 [matéria não assinada]
} 
algo lógico, relacionado ao conteúdo da obra ${ }^{376}$. Exceção no rotineiro processo de negociação entre TV e emissoras, que sempre evitara uma situação limite como essa, o veto a "Roque Santeiro" não podia ser explicado pelo trabalho dos censores em si e sim por uma intervenção direta das Forças Armadas ${ }^{377}$.

Por volta de duas semanas após o cancelamento, a Globo soube por seus "assessores militares" que o SNI havia gravado a conversa entre Dias Gomes e o amigo Nelson Werneck Sodré em que ele contava que iria tentar engambelar os militares fazendo ajustes em alguns personagens de “O Berço do Herói” para transformá-la em "Roque Santeiro". Essa seria a gênese da proibição, ou no mínimo uma parte dela. Boni ligou para Dias Gomes: "Você falou esse troço?" Ele confirmou. "Mas eu falei brincando..." A Globo e o autor jamais disseram ter tido essa informação à época. $O$ grampo só se tornaria público em 1987, quando o jornalista Ayrton Baffa, de "O Estado de S. Paulo", revelaria o conteúdo de diversos documentos até então secretos do SNI. Segundo Dias Gomes, em reportagens da época e em sua autobiografia, foi só aí que ele soube do caso $^{378}$.

Certamente falar sobre o grampo no calor dos acontecimentos seria algo bem mais grave do que questionar a censura. Afinal, como dissemos, o regime havia construído para o cerceamento à liberdade de expressão um arcabouço legal, com o qual buscava legitimar atos de arbitrariedade. Já a escuta no telefonema era claramente ilegal. Relatório do CIE de junho daquele 1975 recebido pelo SNI registrava que as Forças Armadas agiam "muitas vezes ao arrepio da lei”, pois não tinham "outra alternativa, senão a de chamar a si o combate, rápido e enérgico, aos diferentes agrupamentos antirrevolucionários" $" 379$.

\footnotetext{
376 Para a interpretação de Roberto Marinho sobre a caravana, entrevista de Boni à autora.

${ }^{377}$ RIBKE, Nahuel. Decoding television censorship during the last brazilian military regime - The censor as negotiator and censorship as a semi-open interpretative process. Media History, 2011, vol. 17 , n. 1.201

${ }^{378}$ As informações sobre o aviso à Globo do grampo é da entrevista de Boni à autora, que disse que "ou o Ottati ou o Edgardo" teria avisado a emis sora. A declaração de Dias Gomes sobre o fato de ter tido conhecimento do grampo apenas em 1987 não é necessariamente contraditória. É possívelque na época, como costumava ocorrer, is so the tenha soado como mais uma versão dos fatos, entre muitas. E em 1987, a reportagem de Baffa em "O Estado de S.Paulo" abriu o conteúdo do documento, tornando a questão mais clara para todos; BAFFA, Ayrton. His tórias de arquivos do SNI. O Estado de S. Paulo, São Paulo, 15/11/1987.

379 BAFFA, Ayrton. Nos porões do SNI - O retrato do monstro de cabeça oca. Rio de Janeiro: Objetiva, 1989, p. 82
} 
Chamada de "dragão" (as linhas eram grampeadas no cabo do distribuidor geral das centrais, assim surgiu a sigla DG e posteriormente o apelido) ${ }^{380}$, a escuta havia sido feita no telefone de Werneck Sodré, apontado pelo CIE como "jornalista e escritor marxista", que vinha "despontando como o provável coordenador e orientador das campanhas de cunho comuno-esquerdista desencadeadas através da imprensa, particularmente da escrita e televisionada". O grampo durou 24 horas, justo naquele 8 de maio em que ele falou com Dias Gomes sobre "Roque Santeiro". No dia seguinte à leitura do editorial no "JN", uma outra faceta da ditadura, a dos infiltrados (chamados de "besouros"), registrava uma conversa sobre "Roque Santeiro" entre Ênio Silveira, o editor da Civilização Brasileira que havia escrito a orelha do livro com o roteiro de " $\mathrm{O}$ Berço do Herói”, o ex-brigadeiro Francisco Teixeira e o ex-ministro Wilson Fadul ${ }^{381}$.

Ao mesmo tempo em que se debruçava sobre uma telenovela, a inteligência fazia pouco caso de 12 panfletos apócrifos distribuídos entre janeiro e julho daquele ano, todos contrários a Geisel. Como relata Gaspari, o "CIE descobriu que 'a autoria dessa panfletagem parece não ser esquerdista', e a atribuiu a 'grupos inconformados [...] provavelmente de militares da ativa ou da reserva, conhecedores de informes e informações versando sobre as personalidades citadas. Onde havia indisc iplina, insolência e insultos, entendeu que 'o assunto desenvolvido é o abandono pelo Governo dos objetivos revolucionários" 382 .

O falso herói de Dias Gomes estava envolvido em uma trama na qual o próprio presidente não tinha controle de seus órgãos de vigilância e de repressão. Esse panorama de disputa interna entre a linha dura os moderados deve ser considerado na explicação para a censura a "Roque Santeiro", aponta Ribke ${ }^{383}$. Não deixa de ser uma hipótese, nesse sentido, que Geisel tenha pretendido, com a proibição, demonstrar força, diante das acusações de que estava perdendo o controle. O grampo provocativo em que os militares eram, em outras palavras, chamados de bobos por não perceberam a transposição de "O Berço do Herói” para "Roque Santeiro" pode ter sido usado pela

\footnotetext{
380 Para a origem do termo "dragão", GASPARI, Elio. A ditadura derrotada. São Paulo: Companhia das Letras, 2003, p. 412.

${ }^{381}$ Para a anotação sobre Sodré no CIE e a espionagem ao almoço, BAFFA, Ayrton. His tórias de arquivos do SNI. O Estado de S. Paulo, São Paulo, 15/11/1987, p. 86-87.

382 GASPARI, Elio. A ditadura encurralada. São Paulo: Companhia das Letras, 2004, p. 80

${ }^{383}$ RIBKE, Nahuel. Decoding television censorship during the last brazilian military regime - The censor as negotiator and censorship as a semi-open interpretative process. Media History, 2011, vol. 17, n. 1.201
} 
linha mais dura para colocar o presidente na parede, obrigando-a a romper até com a Globo -o fato de o presidente estar acuado também explica a decisão da emissora de expor o governo publicamente no editorial. Em uma espécie de trama paralela, o rompimento da relação de amizade entre Roberto Marinho e Armando Falcão pode ter tornado o ministro um aliado da ideia do veto. Para Boni, o ministro pode ter unido o útil ao agradável, fazer "uma molecagem" com o dono da Globo e agradar o SNI.

O Dias por telefone se "embacaneou" com um troço que não tinha feito: "Driblei a censura, sou craque..." E não era isso, já tínhamos filtrado aquilo. Se o Armando Falcão tivesse um bom entendimento com o dr. Roberto naquele momento, poderia ter visto a novela e dito: "Olha, dr. Roberto, isso aqui tem que consertar". Mas ele não falou nada, não ligou para o dr. Roberto, não havia o que consertar. ${ }^{384}$

Independentemente da exata razão dos militares, a censura a "Roque Santeiro", ainda que, pela força de sua repercussão, seja lembrada como simbólica da repressão cultural da ditadura, deve ser vista como uma quebra na rotina de negociação que pautava a triangulação entre TV, esquerda e governo militar.

Uma semana após o editorial bomba, a agência do Rio de Janeiro do SNI encaminhava à central um documento confidencial cujo assunto era: Complexo Globo $^{385}$. Na abertura, explicava que o levantamento fora feito "atendendo a solicitação verbal da chefia do SNI”. Com 15 páginas, além da capa, listava funcionários de empresas de Roberto Marinho, da TV e Rádio Globo à gravadora Som Livre e até a gráfica. Na sequência dos nomes dos funcionários, seguem resumos de seus prontuários. O documento tem início pela televisão, e o primeiro da lista é Gianfrancesco Guarnieri, “filo-comunista”, cujos trabalhos são “veículos de ‘conscientização' e protesto”. Dias Gomes vem em segundo lugar:

\footnotetext{
384 Entrevista de Boni à autora.

385 SNI, Agência Rio de Janeiro, Encaminhamento no 098/19/75/ARJ/SNI, 4/9/1975
} 
Produz novelas para a TV Globo (núcleo das 20:00), a última delas, "Roque Santeiro", proibida pela Censura, recentemente. Comunista notório e confesso, com longo prontuário na ARJ [Agência Rio de Janeiro do SNI].

Demitido pelo AI-1 da Rádio Nacional. Integra a Base dos Artistas, que apoia o PCB, segundo depoimento de Marco Antônio Tavares Coelho. ${ }^{386}$

Janete Clair surge em terceiro, com informações obtidas também no depoimento de Marco Antônio Tavares Coelho, deputado federal cassado e dirigente do PCB, que foi preso e torturado. Incluída na Base dos Artistas, produz novelas que "adotam a linha da 'conscientização' e do protesto".

Para listar os nomes, é utilizado o alfabeto. Depois de "a)", "b)" e "c)" para Guarnieri, Dias e Janete, chega-se à letra “z)". É preciso começar novamente, e a relação prossegue com “aa)", “ab)"... até “ax)". Isso somente para os dirigentes. Há ainda a relação dos artistas, para o qual são usadas mais três repetições do alfabeto. Vale transcrever aqui alguns dos nomes com resumos dos comentários.

Lauro César Muniz - Produz novelas para a TV Globo, alternando com Dias Gomes, no núcleo das 20:00 [...] A credita que "através da novela, o público chamado de $\mathrm{C}$ pode, subliminarmente, captar uma série de dados novos para a reformulação de ideias e mesmo de vida".

Walter Clark (diretor-geral) e Boni (superintendente)- nada consta.

Borjalo - Diretor de Produção e Programação [...] Sua linha é de esquerda.

Armando Nogueira - Diretor de Telejornalismo. Caracterizado como pessoa que não admite interferência em seu trabalho, já tendo tido atrito pessoal, por esse motivo, com Roberto Marinho, que só não o demitiu por interferência de Walter Clark [...] Viajou para País da "Cortina de Ferro".

Joseph Wallach - Superintendente de Administração. Acusado de ser o homem do Time-Life na TV [...] Infão da ASP [Agência São Paulo do SNI], de março de 1975, configura a posição do epigrafado na TV como contrária ao decreto lei $n^{0} 236 / 67$.

Antônio Abujamra - Diretor do "Caso Especial" [...] Dirigiu a peça “O Berço do Herói”, de Dias Gomes, de impregnação comunista.

Fábio Sabag - Produtor artístico do setor de novelas. Signatário de manifestos de intelectuais e participante de movimento contra a Censura.

386 Ibidem. 
Nelson Motta - Dirige musicais para a TV Globo e tem coluna no jornal "O Globo" [...] É promotor do movimento "underground", na música, e da contracultura [...] Segundo se comenta, é da esquerda que, não vendo solução, aderiu à maconha, ao LSD e aos misticismo oriental. ${ }^{387}$

Motta, descrito com essa curiosa sinopse, para dizer o mínimo, volta a figurar, no mesmo relatório, na sequência de funcionários do jornal "O Globo", que tem como primeiro nome o editor-chefe, Evandro Carlos de Andrade. As informações sobre ele também valem ser transcritas, por envolverem diretamente Roberto Marinho:

Em seu longo prontuário constamvários informes que o dão como comunista; atuaria dentro da cúpula administração do Globo, beneficiando esquerdistas, com nomeações em posições chaves, e afastando os que se opõem às teses marxistas. Isto não está positivado. Em 28 de fevereiro deste ano, Roberto Marinho, em carta ao ministro Armando Falcão, defende vigorosamente o epigrafado contra acusações constantes de informes que diz ter recebido do SNI. Atribuiu as acusações a vinganças de pessoas justamente afastadas das organizações e o diz pronto a responder a qualquer acusação, comparecendo, se solicitado, ao SNI ou a qualquer órgão de informação das Forças Armadas. Nesta mesma carta, Roberto Marinho defende Henrique Caban, Luiz Lobo, Felix Athayde, Wilson Lemos Lage e José Augusto de Sousa Ribeiro. ${ }^{388}$

Três meses depois, o SNI voltaria a fazer outro estudo sobre a "infiltração comunista na TV Globo"389. Esse informe, de 5 de dezembro, assume o acesso a documentos privados, certamente obtidos por meio de infiltrados, ao dizer listar "os elementos que, em abril do corrente, estavam incluídos nas folhas de pagamento da TV Globo". Informa que Dias Gomes e Janete Clair não estão formalmente vinculados à TV porque são contratados para trabalhos específicos. Concentra-se em descrever profissionais não mencionados no informe de outubro, como os atores Mário Lago ("comunista"), Grande Otelo ("foi militante do PC") e os jornalistas Jorge Pontual ("citado como subversivo"), Ivan Lessa ("elemento da "esquerda pornográfica"”), entre

\footnotetext{
${ }^{387}$ Ibidem

388 Ibidem

389 SNI, Agência Rio de Janeiro, Informação nº 242/119/75/ARJ/SNI, 5/12/1975
} 
outros. Há inclusive profissionais acusados de ligação com movimentos armados, como a VPR, e até com o sequestro do embaixador dos Estados Unidos.

Os dois relatórios reforçavam o arsenal araponga sobre a Globo em mão dos militares, que exigiram a demissão de Dias Gomes. Roberto Marinho quis demonstrar força. Não só manteve o dramaturgo como exigiu da direção da TV que enviasse uma sinopse de novela assinada por ele dentre as que seriam submetidas à Censura para substituir "Roque Santeiro"390. Além de duas adaptações ("O Resto É Silêncio”, de Érico Veríssimo, por Marcos Rei, e "Os Cangaceiros”, de José Lins do Rego, por Walter George Durst), seguiu a proposta de "Subitamente os Homens Criaram Asas", de Dias. Edgardo Erichsen logo veio com um recado da ditadura: "Não adianta mandar o Dias que a gente não vai liberar" ${ }^{391}$. Também por esses dias o governo ameaçou inviabilizar a produção de telenovelas com a ideia de exigir que se enviasse previamente todos os capítulos da trama para a classificação, e não apenas a sinopse. Todos, inclusive os militares, sabiam que as novelas são obras abertas, cujos capítulos vão sendo escritos conforme a reação do público, o que é considerado ingrediente do sucesso $\mathrm{o}^{392}$.

Janete Clair, que seguia decepcionada por ter sido tirada do horário das $20 \mathrm{~h}$, resolveu aproveitar a crise para dar a volta por cima. "A novela das oito vai sair aqui de casa. Eu vou escrever. Nós não vamos perder esse horário”, falou ao marido. Deixou os capítulos da sua trama das 19h, "Bravo!", com um assistente, o novato Gilberto Braga, e mergulhou no desafio de convencer a Globo, os militares e ainda elaborar papéis para aproveitar os mesmos atores escalados para "Roque Santeiro"393. Se a inteligência do governo já captava nas obras "melosas" de Janete Clair a intenção de abordar problemas brasileiros, sua nova novela finalmente deixaria isso claro até para a "meia dúzia de intelectuais frustrados" que dela exigiam proximidade com a realidade nacional.

"Pecado Capital" foi aprovada pela Censura no final de setembro, e a Globo deu início à produção a jato. Da imersão no sertão baiano de Asa Branca, o elenco teve de se transpor em questão de dias para o Rio de Janeiro. Francisco Cuoco deixou Roque para trás e incorporou Carlão, um taxista honesto que se vê diante de uma mala de dinheiro

\footnotetext{
${ }^{390} \mathrm{~A}$ informação sobre o pedido de demissão e a exigência de incluir uma sinops e de Dias Gomes são de depoimento do autor ao Projeto Memória da Globo, disponível em robertomarinho.com.br; ${ }^{391}$ Para o nome das outras telenovelas, O Substituto de "Roque Santeiro". Jornal da Tarde, São Paulo, 5/9/1975 [matéria não assinada]; para o recado dos militares, entrevista de Boni à autora.

${ }^{392}$ DINES, Alberto. A Reunião dos Escoteiros - O Jornal dos Jornais. Folha de S.Paulo, São Paulo, $19 / 10 / 1975$, p. 6

${ }^{393}$ XEXÉO, Artur. Janete Clair: a usineira de sonhos. Rio de Janeiro: Relume, 2005, p. 79-80
} 
esquecida em seu carro por um passageiro -que acabara de assaltar um banco. Sem saber da origem da fortuna e sem ter como devolvê-la, ele segue a guardando, até que seu pai tem um problema de saúde e ele decide usar uma parte do dinheiro. E passa o restante da trama em dilema ético, sentindo-se culpado a cada vez que resolve tirar um punhado de notas da mala. Sua noiva é Lucinha, interpretada por Betty Faria, que se despiu da fogosa viúva Porcina para encarnar subitamente uma doce operária de fábrica. Ao som de "Dinheiro na Mão É Vendaval", de Paulinho da Viola", "Pecado Capital" revelava um herói dúbio, com um argumento rico para abordar diversas questões da atualidade brasileira. Com a declarada intenção de se aproximar do estilo do marido ("Levei meu romantismo para o lado realista"), Janete recuperou o horário das $20 \mathrm{~h}$, no qual trabalhou até a sua morte, em 1983, quando escrevia a novela "Eu Prometo"394.

A Globo corria para estrear a nova novela, quando, em 10 de outubro, menos de dois meses após a censura de "Roque Santeiro", o CIE incluía o caso em um "Relatório Especial de Informações", deixando documentada a conexão entre o grampo e a atitude da Censura, e qualificando o editorial do "JN" como "faccioso e insuflador". Eis a íntegra:

A novela de autoria de Dias Gomes que a TV Globo pretendia apresentar diariamente, no horário das vinte horas, “A FABULOSA ESTÓRIA DE ROQUE SANTEIRO E DE SUA FOGOSA VIÚVA, A QUE ERA SEM NUNCA TER SIDO”, não obteve a aprovação da Censura, para aquele horário, por ter sido considerada inadequada para o telespectador juvenil, quer pelo impacto de cenas e diálogos, quer pelo grau de influência dos personagens: revoltados, prostitutas, adúlteras, levianas, aproveitadores, fanáticos etc. É uma "estória mística, de cunho social como matizes de parareligiosidade", onde se destacam a ofensa à moral, à ordem pública e aos bons costumes, bem como achincalhes à Igreja e exagerados registros de cenas amorosas.

Acresce que os Órgãos de Informações comprovaram, em tempo útil, a correlação existente entre a novela e a peça de teatro "O Berço de Heróis" [sic], do mesmo autor, proibida de encenação e que a Editora Civilização Brasileira, no ano de 1965, publicou em livro, cujo prefácio de PAULO FRANCIS, elemento subversivo, de concepções marxistas-leninistas, nos

\footnotetext{
394 Com a sua morte, os capítulos passaram a ser escritor por Glória Perez, sua então aprendiz, sob supervisão de Dias Gomes.
} 
esclarece "que o texto aborda tema político", para mais adiante concluir "que a peça é, naturalmente, subversiva".

Alertada a Censura, iniciaram-se os entendimentos, com avanços e recuos, visando à aprovação da novela. Sentindo a possibilidade de cortes nos trechos em que as "mensagens" seriam enviadas para que "o pessoal pudesse assimilar aquilo que eu queria passar", DIAS GOMES e o grupo de esquerdistas atualmente infiltrados na TV Globo precipitaram o lançamento da novela -“a primeira novela colorida das oito"- para, depois, suspendê-la mediante um editorial faccioso e insuflador. A resposta explicativa da Censura não teve a mesma repercussão na imprensa, onde, dias depois, o mesmo cidadão, cinicamente, proclamava a "inocência" da novela com a qual ele tentava afastar "a influência da cultura estrangeira em nossa televisão".

Dias Gomes, militante do PCB, quando em 1964 foi admitido na Rádio Nacional, como produtor, fez uma adaptação facciosa da peça “Cristo Total", de autoria de uma freira religiosa, explorando e evidenciando ideias comunistas, pregando a luta de classes, lançando operários contra patrões e pobres contra ricos. Tal peça foi irradiada na Sexta-Feira da Paixão daquele ano. Por suas próprias declarações ficou comprovado que agiu sob a orientação do ex-general reformado Nelson Werneck Sodré, comunista, que apresentava em suas aulas no Iseb [Instituto Superior de Estudos Brasileiros] a História do Brasil sob o prisma marxista, cassado pelo AI-1 e que teve seus direitos políticos suspensos pelo prazo de 10 anos. ${ }^{395}$

Menos de duas semanas após esse relatório do CIE e antes de se completar dois meses da censura a "Roque Santeiro", o SNI central recebeu da agência paulistana, em 25 de outubro, a informação de que "às 8:00 de hoje apresentou-se no DOI/CODI/II EX, o jornalista Vladimir Herzog, atual diretor de jornalismo da TV Cultura-Canal 2, para prestar esclarecimento". A nota dizia que "após ser ouvido, confessou ser militante do PCB, colaborador e promotor de reuniões em proveito de reuniões da mesma organização". E encerrava informando que "o nominado permaneceu detido naquele órgão de segurança". Outra mensagem chegou às $22 \mathrm{~h} 08$, afirmando que às cerca de $15 \mathrm{~h}$ o jornalista se suicidara. O suicídio nitidamente forjado -ele teria se enforcado com a cinta do macacão de presos, que não tinha cinta, amarrando-a à cela em um altura que, para morrer, teria que dobrar os joelhos- deixava claro que não só a inteligência agia à

\footnotetext{
395 Centro de Informações do Exército, RPI n ${ }^{\circ}$ 09/75-CIE, 10/10/1975, apud BAFFA, Ayrton. Nos porões
} do SNI - O retrato do monstro de cabeça oca. Rio de Janeiro: Objetiva, 1989, p. 124-128 
revelia do governo. Pior, os porões estavam descontrolados ${ }^{396}$-poucos meses depois, em 17 de janeiro, o operário Manuel Fiel Filho "se suicidaria" no mesmo local de Herzog, segundo a versão oficial, utilizando um par de meias. Relatório do SNI feito em junho de 1975 admitira que nos Doi/Codis, o "modus faciendi" colocado pelo Exército era, "muitas vezes deformado pelo escalão executante". Este, "dispondo já de larga experiência e liberdade de ação, sabe também usá-las, quando necessário, para livrar-se do eficiente controle dos escalões superiores [...] conduzindo a situações delicadas até ao nível presidencial" 397.

A missa em homenagem a Herzog foi um protesto silencioso de 8.000 pessoas contra a ditadura. Como relatou Gaspari, "naquela tarde de 31 de outubro de 1975, a oposição brasileira passou a encarnar a ordem e a decência", enquanto a ditadura, com sua “'tigrada' e seu aparato policial, revelara-se um anacronismo que procurava na anarquia um pretexto para a própria reafirmação". Em entrevista sobre a revelação do grampo do SNI, em 1987, Dias Gomes relacionaria a censura de "Roque Santeiro" aos assassinatos de Herzog e Fiel Filho, em uma época de "maior repressão", de "drástica censura", feita "dos mais diversos tipos de pressão". Um tempo em que "era preciso tentar justificar o aparato de segurança e se procurava demonstrar que havia um grande infiltração nos meios de comunicação". O SNI realmente se empenhou nisso, e Dias Gomes seguiria como alvo. Da censura de "Roque Santeiro" até o fim da ditadura, em 1984, o serviço de informações carimbaria ao menos 59 documentos secretos sobre Dias Gomes. E o falso herói, morto havia dez anos, levaria outros dez para reaparecer vivo.

\footnotetext{
${ }^{396}$ Para o caso Herzog, GASPARI, Elio. A ditadura encurralada. São Paulo: Companhia das Letras, 2004, p. $175-180$.

${ }^{397}$ Para o relatório, BAFFA, Ayrton. Nos porões do SNI - O retrato do monstro de cabeça oca. Rio de Janeiro: Objetiva, 1989, p. 86.
} 


\section{TERCEIRO ATO}

A novela que foi sem nunca ter sido "Roque Santeiro" 2 


\subsection{Capítulo 10}

\section{Asas para voar, sem se divorciar}

Se a proibição de "Roque Santeiro" engavetara, entre outras cenas, a do padre dizendo que "quem tem fé voa", o jeito então para se voar seria criar asas. A sinopse de "Subitamente os Homens Criaram Asas", também chamada de "Quando os Homens Criaram Asas" e, por fim, de "Saramandaia", de Dias Gomes, rejeitada pela Censura para substituir a novela das $20 \mathrm{~h}$ censurada, conseguiu a aprovação para entrar no ar às 22h. Com a nova história, o autor fugia do realismo social que vinha caracterizando suas obras e utilizava o realismo fantástico, sucesso na América Latina. Assim, tentava evitar problemas com a Censura ao mesmo tempo que testava uma nova linguagem na TV. Além do personagem João Gibão, homem com asas, Zico Rosado soltava formigas pelo nariz, Dona Redonda explodia de tanto comer, Marcina, quando excitada, ficava em brasa e queimava tudo, e o Professor Aristóbolu se transformava em lobisomem e encontrava pela noite figuras como D. Pedro I e Tiradentes ${ }^{398}$. Em sua autobiografia, o autor falaria desses símbolos:

Algumas metáforas eram de fácil apreensão, como a do protagonista, João Gibão (Juca de Oliveira), que nascera com asas e era obrigado a cortálas e ocultá-las sob o gibão de couro; no final, sua determinação de deixar $\underline{\text { crescer as as as e voar era um clara alegoria a nosso anseio pelo liberdade }}$ [grifo nosso]. Ou do latifundiário Coronel Zico (Castro Gonzaga) roído internamente por um formigueiro, as formigas saindo-lhe pelo nariz. $\mathrm{Ou}$ ainda a fogosa Marcina (Sônia Braga), cujo corpo, queimando os lençóis da cama, provocava incêndios. Outras eram mais sutis e geravam as mais díspares interpretações, como Dona Redonda (Wilza Carla), que comia tanto, engordava tanto, que um dia explodia. Arthur da Távola entendeu como uma crítica à sociedade de consumo, o que nunca me passou pela cabeça. ${ }^{399}$

Apesar da traumática e tão recente censura de "Roque Santeiro", estava animado com a nova novela, e comentou entusiasmado com o amigo Lauro César Muniz: “Agora

\footnotetext{
398 A descrição dos personagens foi retirada do site teledramaturgia.com.br; http://www.teledramaturgia.com.br/saramandaia-1976/ (acesso em 14/5/2016).

399 GOMES, Dias. Apenas um subversivo. Rio de Janeiro: Bertrand Brasil, 1998, p. 286-287
} 
vou fazer uma história que me anima, descobri um caminho"400. Além de tratar com humor determinados valores morais, queria usar o absurdo para falar da realidade, conforme declarou em reportagem do "Jornal do Brasil" à ocasião do lançamento de "Saramandaia":

A tentativa é fugir do realismo. Ou seja, equilibrar realidade e absurdo. Ou transmitir a realidade através do absurdo do qual muito frequentemente ela se reveste, principalmente nos países latino-americanos, país es como o nosso. Busqueio que havia de fantástico na literatura nordestina, porque "Saramandaia" está incorporada a um painel da própria e dura realidade do Nordeste ${ }^{401}$.

No momento em que elaborava a nova novela, cuja estreia estava marcada para 3 de maio, Dias Gomes voltava a ser alvo do SNI. Em 22 de março, seu nome apareceu em um relatório produzido a partir do depoimento de dois jornalistas ${ }^{402}$, Oscar Maurício de Lima Azevedo e o fotógrafo Luiz Paulo Machado, conhecido por ter feito uma foto de Pelé, num jogo contra o México, em que ele está com uma mancha de suor na camisa no formato de coração. A prisão dos dois, ligados ao PCB, fazia parte da chamada “Operação Grande Rio”. Enquanto em São Paulo os arrastões nos DOIs pretendiam principalmente reforçar as conexões entre o PCB e o MDB (que nas eleições de 1974 conseguira vencer o partido do governo no Senado e em assembleias de importantes Estados), no Rio, o objetivo era também elaborar uma contrapropaganda comunista, fazendo com que os presos se declarassem "arrependidos". A caçada tinha ainda a intenção de expor à sociedade as “'falsas lideranças', 'desmascarando-as e desmoralizando-as, para comprometer suas atividades profissionais atuais ou futuras" "403. O fotógrafo Luiz Paulo Machado foi um dos obrigados a redigir carta se dizendo "arrependido" da militância de esquerda ${ }^{404}$. A informação da Agência Central

\footnotetext{
${ }^{400}$ BASBAUM. Hersch W. Lauro Cés ar Muniz solta o verbo. São Paulo: Imprensa Oficial, 2010, p. 111 401 Jornal do Brasil, 30/4/1976, p. 10, apud. SACRAMENTO, Igor Pinto. Nos tempos de Dias Gomes A Trajetória de um intelectual comunista nas tramas comunicacionais, doutorado na UFRJ, 2012, p. 335-336

402 SNI, Agência Central, Informação no 102/16/AC/76, 22/3/1976

403 Para essa comparação entre os porões de São Paulo e a Operação Grande Rio, GASPARI, Elio. A ditadura encurralada. São Paulo: Companhia das Letras, 2004, p. 256; os trechos entre aspas foram tirados por Gaspari de Relatório Especial de Informações de 23/03/1976.

404 Para a carta de arrependimento de Machado, GOMBATA, Marília. Dom Eugênio, agente duplo. Carta Capital, 18/10/2013, disponível em http://www.cartacapital.com.br/revista/770/dom-eugenioagente-duplo-6767.html (acesso em 13/5/2016).
} 
da inteligência militar trazia na introdução a tese principal da ditadura naquele momento, a de que o PCB formava uma frente ampla que envolvia 'todos os insatisfeitos e contestadores do regime, além de setores político-liberais e a ala progressiva da Igreja Católica". A tomada do poder, apontava o informe, seria por via democrática, para depois ser implantada a "ditadura do proletariado, mediante o afastamento e a neutralização dos antigos aliados". Na estratégia, "o setor das comunicações sociais tornou-se de suma importância". Nesse contexto, para o SNI, estavam as eleições de 1974, o fim da censura nos jornais e a "infiltração de novos elementos na imprensa". O documento detalha de que maneira os comunistas estariam reforçando a luta contra a censura através da ABI, a Associação Brasileira de Imprensa, e lista as organizações formadas em diversos veículos de comunicação, como os jornais "O Globo", "Jornal do Brasill" e "O Pasquim", e as revistas "Veja" e "Manchete". O jornalista e tradutor Luiz Mário Gazzaneo surge como "elemento de ligação com atores e escritores como Dias Gomes, Janete Clair, Bráulio Pedroso e outros, inclusive dandoThes 'assistência' política". Entre os jornalistas citados está Henrique Caban, segundo nome da Redação de "O Globo", de quem os militares tinham longa ficha, e o SNI chegou a exibir um vídeo com a "denúncia” de Maurício Azevedo para Roberto Marinho, Walter Clark e Armando Nogueira ${ }^{405}$. O empresário também teve acesso a um cheque com o qual Caban havia pago sua contribuição ao PCB. Ele manteve sua proteção ao jornalista, mas o chamou para uma bronca:

\author{
- Caban, você deu dinheiro ao Partido Comunista? \\ - Dr. Roberto, durante o Estado Novo, meu pai esteve preso e minha \\ família foi sustentada pelo Socorro Vermelho. Sempre que me pedirem \\ dinheiro para ajudar famílias de preso, eu vou dar. \\ - Mas em cheque, Caban? ${ }^{406}$
}

Uma semana após esse informe do SNI, o governo Geisel praticaria o que Gaspari qualificou de "uma das mais surpreendentes violências de seu governo" 407, e

\footnotetext{
405 Para o vídeo com a denúncia, CLARK, Walter, com PRIOLLI, Gabriel. O campeão de audiência uma autobiografia. São Paulo: Editora Best Seller, 1991, p. 224.

406 A documentação mencionada está no levantamento do SNI feita para a pesquisa. O diálogo de Caban com Marinho foi relatado pelo jornalista a Gaspari; ver GASPARI, Elio. A ditadura encurralada. São Paulo: Companhia das Letras, 2004, p. 256-257.

407 GASPARI, Elio. A ditadura encurralada. São Paulo: Companhia das Letras, 2004, p. 267
} 
Inimá Simões chamou de "provocação gratuita, despojada de qualquer racionalidade" "408: a censura da transmissão, pela TV Globo, de uma apresentação da peça "Romeu e Julieta", do balé russo Bolshoi. A gravação, em comemoração aos 200 anos da companhia de dança, seria exibida para 112 Países, em uma rede mundial de emissoras, lideradas pela norte-americana CBS. No Brasil, entraria no "Fantástico", que já estava com chamadas no ar. Diferentemente do que ocorrera com "Roque Santeiro", desta vez a Censura se preveniu e vetou também que se falasse sobre a proibição, fazendo com que a Globo não pudesse nem informar o cancelamento aos telespectadores, muito menos explicar o motivo ${ }^{409}$. O ministro da Justiça, Armando Falcão, que ordenou diretamente o veto, escreveria em seu livro "Tudo a Declarar": "No ano de 1976, organizara-se um extenso programa de comemoração da passagem da Revolução Russa de 1917. [...] Ora, naquela altura dos acontecimentos, tudo que cheirasse a propaganda da União Soviética era combatido com radicalismo."

Se qualquer ligação soviética era problema, a barra de Dias Gomes estava para lá de suja no SNI. Em 27 de abril, uma semana antes da estreia de "Saramandaia", informe confidencial o listou entre os brasileiros que já haviam feito cursos em países comunistas $^{411}$ e, em 7 de junho, outro documento o colocava entre os conselheiros consultivos do Instituto Cultural Brasil-URSS ${ }^{412}$.

A inteligência também registrou uma conversa presenciada por um "besouro" (informante) entre Dias Gomes e colegas da TV Globo sobre a pressão do governo para que alterasse o enredo de "Saramandaia", no ar desde 3 de maio ${ }^{413}$. Ele não falou desses problemas da novela com a Censura apenas pelos corredores da emissora, mas publicamente, no Encontro Nacional de Professores de Literatura, realizado na PUC do Rio, em 29 de julho. Foi uma pesada crítica, em que citava a censura ao Bolshoi e até a morte do operário Fiel Filho, conforme relato de "O Estado de S. Paulo":

\footnotetext{
408 SIMÕES, Inimá. Nunca fui santa (episódios de censura e autocensura). In: BUCCI, Eugênio (org.). A TV aos 50. São Paulo: Editora Fundação Perseu Abramo, 2000, p. 46 ${ }^{409}$ Para a rede internacional de emissoras, GASPARI, Elio. A ditadura encurralada. São Paulo: Companhia das Letras, 2004, p. 267; para a censura ao "Fantástico", SIMÕES, Inimá. Nunca fui santa (episódios de censura e autocensura). In: BUCCI, Eugênio (org.). A TV aos 50. São Paulo: Editora Fundação Perseu Abramo, 2000, p. 46

${ }^{410}$ FALCÃO, Armando. Tudo a declarar. São Paulo: Nova Fronteira, 1989, p. 374, apud GASPARI, Elio. A ditadura encurralada. São Paulo: Companhia das Letras, 2004, p. 268

411 SNI, Agência Central, Informe nº 091/16/AC/76, 27/4/1976

412 SNI, Agência Rio de Janeiro, Informação n 136/032/76/ARJ/SNI, 7/6/1976

413 BAFFA, Ayrton. Nos porões do SNI - O retrato do monstro de cabeça oca. Rio de Janeiro: Objetiva, 1989, p. 129
} 
Explicando por que está usando o absurdo em suas últimas novelas, Dias Gomes revelou que, na televisão, só pode dar uma pálida ideia da realidade nacional e que o realismo só não basta para retratá-la, pois o que está acontecendo aquié o absurdo, como a proibição da exibição do Balé Bolshoi ou o fato de um operário ter-se enforcado na prisão com uma meia de seda. Observou ele que, por exemplo, na novela "Saramandaia", não pôde focalizar o problema da seca. Por isso, só resta o folclore. ${ }^{414}$

A cobertura da "Folha de S.Paulo" abriu com uma declaração do autor relacionando diretamente o absurdo da trama à censura.

\footnotetext{
"A censura, o populismo, as contradições sociais e a cultura popular são parte de uma realidade brasileira que a estética do realismo não mais explica. A realidade brasileira é absurda e, sem o absurdo, o realismo não exprime a realidade apropriadamente. São absurdos os dias dos brasileiros, o nosso cotidiano, e por is so a realidade nacional só poderá ser explicada pela conjugação do realismo com o absurdo."415
}

Ao final, a matéria conta que Dias Gomes concordara com um professor presente ao evento que havia dito que, na TV, o debate político afundara em superficialidade sob a vigilância da Censura. "Mesmo os problemas importantes que a Censura nos deixa tocar na televisão só podem ser apresentados de forma superficial, folclórica”, disse o autor. 'Em 'Saramandaia', por exemplo, eu falo do desemprego, ou que as frentes de trabalho não resolvem nada, mas isso a Censura corta, isso eles não deixam passar. Fica então só o folclore." Em 1998, na autobiografia, escreveria sobre essa novela que, "trabalhando com símbolos e metáforas, tornava dificil o trabalho dos censores, embora não evitasse cortes e mais cortes". E confessaria um "estratagema": "Como os critérios da Censura eram extremamente variáveis e os censores eram trocados frequentemente, eu repetia uma cena vetada 20 capítulos adiante e, se novamente cortada, voltava a repeti-la até vê-la aprovada" ${ }^{416}$. Nesse mesmo ano do lançamento da autobiografia, daria mais detalhes sobre a censura a "Saramandaia" em entrevista a David José Lessa

\footnotetext{
${ }^{414}$ Folclore, a saída para Dias Gomes. O Estado de S. Paulo, 30/7/1976 [matéria não assinada] 415 Declaração de Dias Gomes transcrita em Dias Gomes e o abs urdo da realidade. Folha de S.Paulo, 31/7/1976, p. 27 [matéria não assinada]

416 GOMES, Dias. Apenas um subversivo. Rio de Janeiro: Bertrand Brasil, 1998, p. 286
} 
Mattos, para o livro 'Pioneiros do Rádio e da TV no Brasil", em que narra uma curiosa conversa que teve com censores em Brasília:

\begin{abstract}
"Saramandaia" foi também muito perseguida pela Censura. Eu a escrevi logo depois da proibição de "Roque Santeiro". Por isso, apelei para o realismo fantástico, o que deixou a Censura meio perdida. A Censura não entendia bem a novela e passou a fazer cortes aqui e ali, indiscriminadamente. Os cortes chegaram a tal ponto que não dava para continuar a história. Como acontecia sempre nessas situações, eu ia a Brasília para discutir com os censores. Lá, o chefe da Censura era uma pessoa muito amável, muito delicada e costumava dar atenção quando eu o procurava. Numa das vezes em que estive lá, disse a ele: "Gostaria que o senhor me explicasse algumas coisas. Por exemplo, vamos suporque, de hoje em diante, eu quisesse ser um bom moço e quisesse seguir a orientação da Censura. Nesse caso, gostaria de saber que critérios deveria seguir. Pergunto isso porque há vários cortes aqui no texto que até entendo o porquê, mas outros não consigo entender. Falo especificamente des se texto aqui, nesta página, que já li uma porção de vezes e não vejo nenhum motivo para cortes. Trata-se de um diálogo entre dois jovens, em que não se fala de política ou de problemas morais. Não vejo nenhuma razão para esse corte". Depois de me ouvir atentamente, o chefe da Censura leu o diálogo que lhe apontei e disse: "É. Realmente também não atino por que razão foi cortado". Em seguida, mandou chamar o censor responsável pela novela e lhe perguntou porque ele havia censurado aquele diálogo. "Fulano, o Dias Gomes está intrigado", ele disse, "e eu também. Por que você cortou isto aqui?". O censor ensaiou, então, uma pose, fez um ar de inteligente e, olhando para mim, disse:"Bem, o que o senhor colocou aí no texto, quando se lê, parece não ter problema nenhum, não é? Mas o que o senhor estava pensando quando escreveu esse diálogo, aí é que está o problema”. Vejam só, ele havia censurado o meu pensamento! A que ponto chegou a censura no regime militar! ${ }^{417}$
\end{abstract}

O tema da censura no Brasil ganharia palco internacional no final de 1976. Quando escrevia os últimos capítulos de "Saramandaia", que ficaria no ar até 31 de dezembro, Dias Gomes foi convidado para dar um seminário sobre sua obra na Pennsylvania State University, nos Estados Unidos. A cada ano, a universidade escolhia

${ }^{417}$ MATTOS, David José Lessa (org.). Pioneiros do rádio e da TV no Brasil. São Paulo: Códex, 2004, p. $82-83$ 
um dramaturgo para passar dez semanas ministrando aulas sobre a sua produção. Dois anos antes, o convidado fora Jorge Amado. A viagem estava marcada para setembro, mas Dias Gomes teve sérias dificuldades para embarcar. O problema não foi o visto norte-americano, e sim a liberação do passaporte. O governo temia que o autor fosse "fazer propaganda contra o Brasil nos Estados Unidos", conforme ele narrou em sua autobiografia $^{418}$. O tema chegou ao SNI. Em 16 de setembro, o Centro de Informações da Aeronáutica (Cisa) respondeu a pedido de busca do dia 10 daquele mês sobre o dramaturgo, em razão da solicitação de viagem. A resposta foi que nada tinha a comunicar que impedisse Dias Gomes de ausentar-se do País ${ }^{419}$. Em 28 de setembro, a Divisão de Segurança e Informações do Ministério da Justiça distribuía a notificação de que, entre "elementos que solicitaram autorização para viajar ao exterior", estava Dias Gomes, cujo currículo continha a demissão da Rádio Nacional em razão do AI-1 e IPM para apurar atividades do PCB. O documento seguiu com ampla distribuição, sendo enviado para a Agência Central do SNI, o Centro de Informações do Exército (CIE), as agências central e carioca do Cisa e o Centro de Informações da Marinha (Cenimar) ${ }^{420}$.

O autor teve de usar "o prestígio da TV Globo", conforme relatou na autobiografia, a fim de conseguir a autorização dos militares, que deixaram claro que a porta só estaria aberta para a sua volta se ele se comportasse bem na viagem. No embarque, a polícia alfandegária fez rigorosa revista da bagagem do autor e de Janete Clair, e ainda checou com superiores se os dois poderiam mesmo deixar o País ${ }^{421}$.

Na universidade norte-americana, Dias Gomes, além de falar sobre a sua obra, deu palestras a respeito da história do teatro brasileiro. "O Pagador de Promessas" e "O Berço do Herói” foram temas, cada uma das peças, de duas aulas. Ao final do curso, os estudantes encenaram "The Cradle of the Hero". E, assim, "O Berço do Herói”, proibida no Brasil por ser acusada de comunista, tinha a sua estreia mundial em um teatro de uma pequena cidade do centro mundial do capitalismo. Em 30 de novembro, reportagem do "Jornal do Brasil" anunciava a volta do dramaturgo ao País e resumia os dois meses que ele passara nos EUA. O título era: “Herói de Dias Gomes nasceu em berço norte-americano".

\footnotetext{
418 GOMES, Dias. Apenas um subversivo. Rio de Janeiro: Bertrand Brasil, 1998, p. 291

419 Ficha 004/Cisa em resposta a pedido de busca $n^{\circ} 0795 / 76-\mathrm{SI} / \mathrm{SR} / \mathrm{RJ}$ de 10/9/1976

420 Divisão de Segurança e Informações do Ministério da Justiça, Informação no 815/76/DSI/MJ

${ }^{421}$ Para as informações sobre o uso do prestígio da TV Globo e os problemas no embarque, GOMES,

Dias. Apenas um subversivo. Rio de Janeiro: Bertrand Brasil, 1998, p. 291-292
} 
No SNI, o ano de 1976 se encerrou para Dias Gomes com um apontamento internacional ${ }^{422}$. O Ministério das Relações Exteriores, por meio de seu Centro de Informações, registrou a estreia de uma montagem de "O Santo Inquérito" em Portugal, que respirava ares de liberdade desde a Revolução dos Cravos, em 1974. Seria a primeira encenação do autor no país. Antes, na ditadura salazarista, a peça "O Pagador de Promessas" havia sido censurada. O autor viajou a Lisboa para a apresentação, onde foi aplaudido pelo trabalho no teatro e pela militância política ${ }^{423}$.

$*$

Era véspera de Natal de 1976 quando a capa da "Ilustrada", da "Folha de S.Paulo", estampou a manchete: "Censura". Parecia impossível, até porque a Globo redobrara esforços para negociar com os militares desde "Roque Santeiro", mas o drama se repetia, e a novela "Despedida de Casado", que substituiria "Saramandaia" às 22h, foi vetada 12 dias antes da estreia, marcada para 4 de janeiro. Foi a segunda e última novela a ser proibida, na história do Brasil, já com os capítulos gravados.

A trama era assinada por Walter George Durst e abordava um tema tabu à época, o desquite, com a história de três casais que discutiam a relação com um psicanalista. Para os censores, pregava a dissolução do casamento ${ }^{424}$ (a Lei do Divórcio estava em discussão no Congresso e seria aprovada no final de 1977).

As dificuldades com a Censura já haviam adiado a estreia, a fim de que alguns capítulos fossem reeditados. Em vão. A Globo recebeu o veto definitivo em 23 de dezembro e, após reunião entre Boni, Joe Wallach e Walter Clark, decidiu soltar uma nota à imprensa:

A exibição da novela "Despedida de Casado", que já estava com 30 capítulos gravados, foi vetada ontem pela Censura. A Rede Globo de Televisão, diante da atitude censorial, colocará no ar, para preencher o

\footnotetext{
422 Ministério das Relações Exteriores, Centro de Informações do Exterior, Ciex n 456/76, 3/12/1976 423 Para a viagem do autor a Portugal, GOMES, Dias. Apenas um subversivo. Rio de Janeiro: Bertrand Brasil, 1998, p. 297-299.

${ }^{424}$ Para a opinião dos censores, SIMÕES, Inimá. Nunca fui santa (episódios de censura e autocensura). In: BUCCI, Eugênio (org.). A TV aos 50. São Paulo: Editora Fundação Perseu Abramo, 2000, p. 46; para a informação sobre a negociação entre a Globo e a Censura, Censura - Também é proibida a "Despedida de Casado". Folha de S.Paulo, 24/12/1976, p. 21 [matéria não assinada]
} 
horário, a novela "O Bem-Amado", em capítulos condensados, até que o departamento de produções prepare outra novela para o horário das 22 horas. ${ }^{425}$

No "Jornal do Brasil", a reportagem sobre a censura foi assinada pelo então repórter Artur Xexéo. Quase 20 anos depois, em sua coluna no mesmo jornal, ele revelaria que José Leite Ottati, o censor interno da Globo, havia the contado na ocasião ter alertado a emissora que o tema do desquite não seria aprovado pela Censura, mas a direção da Globo decidira arriscar ${ }^{426}$. Em 25 de dezembro, dia seguinte à notícia do veto, o jornalista da "Folha" Tarso de Castro escreveu sobre o novo episódio de proibição drástica na teledramaturgia. Para ele, o veto não tinha "nada de excepcional, pelo seguinte fato: uma permanente ditadura, por parte de quem quer que seja que mantenha o poder, sobre as televisões". A ditadura, apontava, era diretamente ligada ao poder da concessão do canal pelo Estado:

Não morro de amores pelos grupos que dominam as televisões -e que podem tranquilamente serclassificados pelo pior adjetivo que você tem na cabeça neste momento- mas o fato é que não existe nem mesmo a mínima liberdade para que eles façam alguma coisa. E isso se deve ao óbvio: a concessão dada para a exploração do canal é uma espécie de guilhotina preparada para cortar o pescoço de quem quer que seja na hora que interessar. É verdade que não acredito que alguém tivesse coragem -falei coragem exatamente - para tirar a Globo do ar. Mas o pessoalda Globo acredita. Digo, irmão teme irmão. E, assim sendo, o pessoalda Censura se diverte. ${ }^{427}$

Como relatamos, na ocasião do editorial sobre a censura de "Roque Santeiro", Walter Clark temeu a retirada do canal no ar, o que está longe de significar a perda da concessão, mas que já seria extremamente grave. Não se sabe se esse temor está por trás da reação mais branda da Globo ao veto de "Despedida de Casado", que divulgou apenas uma nota à imprensa, bem mais curta e menos impactante do que o editorial.

\footnotetext{
425 Censura - Também é proibida a "Despedida de Cas ado". Folha de S.Paulo, 24/12/1976, p. 21 [matéria não assinada]; reportagem posterior da "Ilustrada", em 4/1/1977, quando a novela deveria estrear, afirma que dez capítulos, e não 30, já estavam previamente gravados (SOARES, Dirceu.

Televisão. E essa novela vai passar? Folha de S.Paulo, 4/1/1977, p. 29).

${ }^{426}$ Para a informação sobre Xexéo, KUSHNIR, Beatriz. Cães de Guarda - Jornalis tas e censores do AI-5 à Constituição de 1988. São Paulo: Boitempo, 2004, p. 101

427 CASTRO, Tarso de. Despedida de conquistado. Folha de S.Paulo, 25/12/1976, p. 20
} 
Também não houve de caravana de globais a Brasília, apenas uma tentativa do próprio autor, que esteve com os censores para tentar reverter a decisão ${ }^{428}$. Certamente, um ano e meio depois da censura a "Roque Santeiro", o clima do País era outro. A ilusão da abertura ficara para trás a partir do recrudescimento da repressão, das mortes de Herzog, Fiel Filho e de outros. Só na operação anti-PCB em São Paulo, mais de 200 pessoas haviam sido pressas, e 16 dirigentes partidários foram assassinados ${ }^{429}$. Além disso, conforme lembra o livro "Brasil: uma biografia", "entre os meses de setembro e agosto de 1976, bombas foram detonadas ou encontradas e desativadas a tempo nas sedes da CNBB [Conferência Nacional dos Bispos do Brasil], OAB [Ordem dos Advogados do Brasil] e ABI [Associação Brasileira de Imprensa]". Uma delas explodira na casa de Roberto Marinho. ${ }^{430}$ Em 22 de setembro, ou seja, três meses antes da censura a "Despedida de Casado", aconteceu o atentado, como relata Gaspari:

Roberto Marinho estava deitado na cama do quarto de sua casa, no Cosme Velho, e foi atirado ao chão. Uma bomba explodira embaixo da janela. Era o terceiro atentado da noite. Primeiro sequestraram Dom Adriano Hipólito, bispo de Nova Iguaçu, e deixaram-no nu, pintado de vermelho na beira de uma estrada. Pouco depois, os terroristas foram à Gloria e detonaram um automóvel em frente à sede da Conferência Nacional dos Bispos do Brasil. Daí, subiram para a casa de Roberto Marinho. A Censura proibiu referências aos episódios.

Aquilo era pedra cantada. O general Ednardo D'Avila Mello fora demitido do comando do II Exército depois do assassinato do operário Manuel Fiel Filho, e o ministro da Justiça, Armando Falcão, avisara ao presidente Geisel que existia a "possibilidade de agressão a elemento dos meios de comunicação social, a pretexto de desagravaro Exército". Dias antes, explodira uma bomba na ABI e outra na sede do Cebrap, o centro de pesquis as paulista fundado porFernando Henrique Cardoso.

Assim como tinha garçom e cozinheiro, Roberto Marinho valia-se dos serviços do mais conhecido detetive particular do Rio. Era Bechara Jalkh. Ele trabalhou no caso por cerca de três meses e fechou o círculo. Os três atentados vinham de um mesmo núcleo. Com o tempo, soube-se que nele

\footnotetext{
${ }^{428}$ Para o encontro de Durst com os censores, SIMÕES, Inimá. Nunca fui santa (episódios de censura e autocensura). In: BUCCI, Eugênio (org.). A TV aos 50. São Paulo: Editora Fundação Perseu Abramo, 2000, p. 46.

${ }^{429}$ SCHWARCZ, Lilia M. e STARLING, Heloisa M. Brasil: uma biografia. São Paulo: Companhia das Letras, 2015, p. 472

430 Ibidem, p. 481
} 
estava um sócio fundador do Centro de Informações do Exército que servia no Serviço Nacional de Informações.

A surpresa veio num detalhe: no grupo estava um ex-repórter do

"Globo", responsável pela cobertura do setor militar. 431

Se a Censura havia proibido notícias sobre os atentados e o veto ao Bolshoi, é possível que tenha coibido a cobertura da interdição de "Despedida de Casado". Para Boni, o comportamento distinto da Globo nesse episódio em relação ao de "Roque Santeiro" deveu-se às formas como agiu a Censura nas duas ocasiões:

No caso de "Roque Santeiro", eles nos ludibriaram até a data da estreia, de forma planejada para nos causar problemas. Já "Despedida de Casado" recebeu a proibição dez dias antes, ou seja, dentro da rotina, permitindo que, na promoção, avisássemos que a novela não iria ao ar. No caso de "Roque Santeiro", o ponto de destaque foi informar que estávamos sob censura. No de "Despedida", a movimentação dos artistas foi considerada como estrategicamente melhor para mostrar que não estávamos defendendo somente os interesses da empresa. ${ }^{432}$

Esse depoimento, somado ao relato de Xexéo sobre o alerta de Ottati, dão uma dimensão de que a emissora provavelmente estava mais preparada para essa proibição, até porque já passara pela experiência com "Roque". Apesar disso, só conseguiria estrear uma nova novela seis meses depois (tempo em que manteve no ar a reprise de “O Bem-Amado"). Em 1975, "Pecado Capital", feita para o lugar de "Roque Santeiro", entrou no ar menos de três meses depois da censura (a correria certamente foi maior porque se tratava do horário das $20 \mathrm{~h}$, de maior audiência e lucratividade do que o das 22h). Em 27 de junho de 1977, estreou 'Nina", também escrita por Durst e com a mesma equipe de "Despedida de Casado". Já o roteiro foi completamente alterado: de uma contemporânea história sobre a separação de casais para uma trama de época, ambientada nos anos 1920.

O diretor da Divisão de Censura de Diversões Públicas (DCDP), Rogério Nunes, deu entrevista coletiva à imprensa, em 30 de dezembro de 1976, menos de uma semana

\footnotetext{
431 GASPARI, Elio. Uma bomba na noite. O Globo, 29/7/2015, disponível em http://oglobo.globo.com/sociedade/uma-bomba-na-noite-16986664 (acesso em 16/5/2016); o nome do exrepórter do Globo não é revelado.

432 Troca de e-mails com a autora em 9/5/2016.
} 
após o veto a "Despedida de Casado", e afirmou que "a censura sempre existiu e existirá em toda sociedade organizada". Ao ser questionado a respeito do fim desse tipo de repressão no Brasil, afastou essa possibilidade, dizendo que o governo tinha, em pesquisas, constatado a censura em pelo menos 150 países. "Ela tem início dentro de casa, no ambiente familiar", argumentou. Negou que os censores tivessem prevenção contra determinados artistas, como Chico Buarque e Dias Gomes. Em relação à proibição de "Despedida de Casado", afirmou que os motivos para dissolução dos casamentos, no enredo da novela, foram considerados contrários à moral e aos bons costumes. E foi muito claro sobre como deveria ser o relacionamento entre a Censura e a televisão:

"Não posso obrigar a televisão a remeter os textos definitivos à Censura. Se os interessados alegam inexistência de leis e não apresentam o texto [completo das telenovelas] e depois a peça é censurada, o problema é deles. Eles têm que fazer seus trabalhos em função da Censura e não a Censura em função deles." [grifo nosso] ${ }^{433}$

Também comentou um anteprojeto de lei coordenado pelo ministro Armando Falcão para atualizar a legislação censória, que era pautada principalmente no decreto 20.493, de 1946. Não eram alterações animadoras. A TV seria incluída. Não estava no decreto de 1946 porque seria lançada depois, em 1950. O objetivo dessa inclusão, claro, era um controle ainda maior. Disse que havia uma discussão para que o Conselho Superior de Censura (criado por lei em 1968 para rever decisões mas até então não implementado) tivesse o número de membros reduzido, de 15 para cinco. E sem representantes da sociedade civil, todos os integrantes viriam do governo. Para Nunes, a legislação brasileira era "liberal". "Posso comprovar isso com o grande número de cartas que nos são escritas por entidades profissionais, religiosas, câmaras municipais que reclamam contra o nosso liberalismo", afirmou.

Com essas palavras se encerrava o ano de 1976, que foi "pior que o de 1975", no balanço que Alberto Dines fez em sua coluna "Jornal dos Jornais", da "Folha", de 2 de janeiro de 1977. O jornalista ponderou que havia sido de "meia censura", pois "a nação inteira acabou tomando conhecimento daquilo que apenas a minoria do 'metier' e dos

433 Censura - O diretor diz como salva a nossa moral. Folha de S.Paulo, 30/12/1976, p. 36 [matéria não assinada] 
círculos intelectuais sabia", uma vez que os jornais estavam noticiando os vetos. Por outro lado, escreveu, o governo "permitiu que os atentados terroristas da extrema direita contra instituições e empresas jornalísticas continuassem impunes". Nessa omissão, analisou, “em código está a mensagem: 'Vocês que se cuidem’ [...] O governo deixa assim à sanha dos radicais aqueles que continuam resistindo às violências da censura oficial, numa aliança que, se não é prática, é teórica." Mais de um ano depois de ter elogiado o editorial do "JN" sobre a censura de "Roque Santeiro", Dines criticava a reação "cabisbaixa" ao veto de "Despedida de Casado":

A Rede Globo, que no caso da proibição de "Roque Santeiro" teve um comportamento digno e altamente elogiável, levando ao ar uma nota firme e discreta da sua direção informando sobre a violência, desta vez ficou totalmente cabisbaixa. [...]

O governo não teria coragem de suspender a Rede Globo se essa tivesse a hombridade de veicular uma nota discreta de registro sobre a coação sofrida. Um dia sem TV seria o caos neste País. A força da Rede Globo é muito maior do que a da censura, mas neste triste momento nacional os fortes preferem agir como fracos. Esquecem apenas que neste jogo perde-se a vitalidade. Poderio não utilizado acaba secando.

A censura redobrou de intensidade e a autocensura, seu abominável subproduto, es tá campeando. ${ }^{434}$

No primeiro dia de 1977, a coluna de TV da "Ilustrada", "Helena Silveira Vê TV", tinha a manchete "77 sob ameaça da Censura". Após discorrer a respeito dos vetos de 1976 ao Bolshoi e à "Despedida de Casado", "quando se imaginava que o episódio de 'Roque Santeiro' seria singular", encerrou a colunista: "Feliz 1977? Vamos ver."

${ }^{434}$ DINES, Alberto. Balanço e sacolejo (O Jornal dos Jornais). Folha de S.Paulo, 2/1/1977, p. 6 


\subsection{Capítulo 11}

\section{Espelho quebrado da burguesia}

Não, 1977 não seria um ano feliz para a liberdade de expressão. Em janeiro, o ministro Armando Falcão recebeu um manifesto de repúdio à censura com mais de mil assinaturas, e o seu procedimento foi encaminhá- lo à Polícia Federal. Já em 17 de fevereiro, o SNI registrava que Dias Gomes estava entre os "intelectuais" (que o documento coloca entre aspas) que haviam assinado o documento ${ }^{435}$. A informação secreta destacava o dramaturgo, além do arquiteto Oscar Niemeyer e do historiador Nelson Werneck Sodré, entre os "elementos ligados aos comunistas e soviéticos".

Uma semana antes desse informe do SNI, Dias havia gravado um depoimento para o Museu da Imagem e do Som (MIS), no Rio, em que dissera nunca ter entendido a censura, "a não ser como uma coisa surrealista". Sobre "O Berço do Herói”, respondera "ter esperança" na liberação da peça, mas não como uma "perspectiva imediata" ${ }^{436}$. De fato, a obra não seria encenada tão cedo nem nos palcos nem na sua versão televisiva. Entre o veto da novela, em 1975, e o ano de 1977, a Globo fez outras duas tentativas de liberar "Roque Santeiro", ambas negadas, com a explicação extraoficial de que a novela tinha virado um símbolo da repressão e que colocá-la no ar seria uma provocação ${ }^{437}$.

Logo ficaria claro que Dias Gomes estava certo no prognóstico cauteloso em seu depoimento ao MIS. A ditadura ganhou sobrevida com o Pacote de Abril, em que o governo fechou o Congresso por duas semanas para que pudesse alterar regras eleitorais. Com as canetadas, tornou indiretas as eleições para governador em $1978 \mathrm{e}$ ampliou de quatro para seis anos o mandato do sucessor de Geisel. Também deu força à Arena ao instituir que um terço do Senado seria escolhido por um colégio eleitoral de maioria governista (os ocupantes do cargo foram apelidados de senadores biônicos). A Lei Falcão, assinada por Geisel no ano anterior, foi ampliada, fazendo com que, nas campanhas eleitorais de deputados no rádio e na TV, os candidatos não pudessem falar (só seria permitido exibir uma imagem do político, acompanhada de um resumo de seu

\footnotetext{
${ }^{435}$ SNI, Agência Rio de Janeiro, Informação n ${ }^{\circ}$ 19/032/77/ARJ/SNI

${ }^{436}$ Dias Gomes grava seu depoimento. Jornal do Brasil, 10/2/1977 [matéria não assinada]

${ }^{437}$ Para as tentativas de liberar "Roque Santeiro" entre 1975 e 1977, entrevista de Boni à autora; para a explicação extraoficial, declaração de Dias Gomes em COURI, Norma. Playboy entrevista Dias Gomes. Playboy, ed. $125,12 / 1985$, p. 52
} 
currículo $)^{438}$. Ao justificar a lei que criou e ganhou seu nome, Armando Falcão diria, em sua autobiografia, que "um dos fatores mais decisivos para triunfar nos pleitos eleitorais sempre esteve na força da televisão e do rádio".

Esse clima de retrocesso se fez sentir em entrevista de Dias Gomes no início de maio ao "Jornal do Brasil", cujo título era uma frase pinçada de suas declarações, "Somos uma geração de quixotes":

"Muitas vezes esperei que um dos meus filhos me olhasse nos olhos e dissesse: 'Puxa, pai, vocês não podiam ter feito nada para evitar?!' Eu não saberia o que lhe responder. Talvez gaguejasse uma defesa. 'É, filho, infelizmente nós nem acreditássemos que fosse possível chegar aos negros tempos a que hoje chegamos.'."439

O endurecimento político do País, o cansativo processo industrial das telenovelas, a censura sistemática aos capítulos e até o sucesso rotineiro fizeram com que o dramaturgo se declarasse desmotivado em sua carreira televisiva. A solução encontrada por ele e pela Globo foi um projeto que prometia inovar a teledramaturgia. O autor estava livre para propor um formato, documentário, série, até filme. Com a carta branca concedida pela Globo, escolheu um tema espinhoso para o governo: a classe média. Ao falar do projeto, que iria da formação desse estrato social até a contemporaneidade, a "Folha de S.Paulo", em 4 de julho, deu à matéria a provocativa manchete "A classe média vista no espelho favorito", e informou que o nome provisório do programa era "Os Grandes Sonhos de Nossos Pequenos Burgueses" $"$. Seriam óbvias as dificuldades com a Censura, tão zelosa da "moral e os bons costumes" da burguesia.

Um documento produzido pela Agência Central do SNI nesse mesmo mês de julho, com base em reunião realizada pelos chefes das agências regionais, evidenciava a preocupação com obras que pudessem abalar a moral burguesa e deixava claro que essa

\footnotetext{
438 Para o Pacote de Abril, SCHWARCZ, Lilia M. e STARLING, Heloisa M. Brasil: uma biografia. São Paulo: Companhia das Letras, 2015, p. 468, e CPDOC da FGV, disponível em http://cpdoc.fgv.br/producao/dossies/Fatos Imagens/PacoteAbril (acesso em 17/5/2016).

439 Dias Gomes - "Somos uma geração de quixotes". Jornal do Brasil, 4/5/1977 [matéria não assinada] 440 A classe média vista no espelho favorito. Folha de S.Paulo, 4/7/1977, p. 23 [matéria não assinada]; informações sobre o projeto também foram retiradas entrevista do autor à Veja: Livre. Veja, 29/6/1977 [matéria não assinada].
} 
vigilância tinha fundamento político ${ }^{441}$. O texto, que seria distribuído às regionais e aos "analistas da área psicossocial", tratava da infiltração comunista e de sua estratégia "pacífica para a tomada do poder". Chamado de "Atuação nos meios de comunicação social na formação e condução da opinião pública", apontava mais diretamente para a "dissolução da moral e dos costumes" ao abordar o cinema e a disseminação das chanchadas, que contribuíam para "enfraquecer as barreiras morais, passo importante para a conquista de uma nação" (grifo nosso).

Apresentava questões específicas de cada veículo de comunicação. Sobre os proprietários, analisava que eles, "como é óbvio", seriam, "em princípio, contrários à doutrina marxista", mas que alguns, "seja por conviç̧ões liberais, seja por comodismo ou ainda pelo interesse puramente econômico, acabam, muitas vezes, fazendo concessões aos comunistas". Articulistas liberais de jornais eram chamados de "inocentes úteis" ao "apresentar um quadro pessimista da conjuntura nacional" em seus textos. Denunciava um "esquema muito bem planejado" em que "os elementos porventura dispensados de um veículo logo são admitidos em outros", dando como exemplo o fato de Mino Carta, depois de ser demitido da "Veja" por "algumas pressões do governo", ter sido contratado pela Editora Três para estruturar a "Isto É". Abordava a ascensão da imprensa alternativa a partir da censura prévia nos grandes jornais. Esse dispositivo censório, explicavam, "quando instituído para resguardar a moral e os bons costumes, tem como base o decreto lei de $\mathrm{n}^{\mathrm{o}} 1.077$, de 26 de janeiro de 1970, e quando por implicações político-ideológicas, o AI-5".

O relatório apontava a televisão como um veículo "de enorme poder de persuasão", que "merece destaque na luta ideológica". E relacionava o controle do Estado à outorga de concessão, além de mencionar especificamente a apreensão dos militares com as novela e seus autores esquerdistas, entre os quais listava Dias Gomes, Lauro César Muniz e até Janete Clair:

Cumpre ressaltar que, à importância desses veículos, se contrapõe um controle mais rígido por parte do Governo. A exploração das emissoras de rádio e televisão se faz através de concessão da União [...].

Salienta-se, também, que os elementos que solicitam renovação de concessão, ou outorga de nova concessão, passampor uma triagem no SNI, a

${ }^{441}$ SNI, Agência Central, Encaminhamento $n^{\circ}$ 072/19/AC/77, 26/7/1977 
qual visa a impedir que o controle das emissoras de rádio e televisão fiquem nas mãos de elementos ideologicamente comprometidos ou envolvidos em corrupção.

A infiltração no rádio e na televisão, como nos grandes jornais, se processa a partir dos segundos escalões e atua de maneira mais concreta nos noticiosos, nas novelas e nos programas humorísticos [...]

Já as novelas, que há alguns anos eram consideradas alienantes pela “esquerda festiva”, passaram devido à grande audiência [de] que desfrutam, a ser encaradas como veículos ideais para a difusão de mensagens claras ou subliminares de críticas ao regime ou exaltação do marxismo. A partir daí, vários autores especializaram-se em escrevernovelas políticas para a televisão. Entre estes destacam-se, por seus trabalhos bem-sucedidos, Dias Gomes, sua esposa, Janete Clair, Lauro César Muniz e Mário Prata, autores de trabalhos de claro teor político-ideológico, como "O Bem-Amado", "Fogo Sobre Terra", "Saramandaia", "Escalada", "O Casarão" e "Estúpido Cupido". ${ }^{442}$

Ao final, o SNI instruía os representantes das agências regionais que fossem utilizar o relatório para uma palestra a “comentar o caso da novela 'Roque Santeiro', de Dias Gomes". E demonstrava completa ignorância sobre a obra, ao dizer que "nada mais era do que o livro "Berço de Heróis", do comunista Nelson Werneck Sodré, cuja adaptação para o teatro fora proibida pela Censura".

Por fim, alertava para o financiamento público de obras da esquerda, especialmente no teatro e no cinema, o que tornava evidente uma "dicotomia entre o Ministério da Educação e o Ministério da Justiça". Citava como exemplo o caso de Tristão de Ataíde, o mesmo que, em 1965, escrevera artigo na "Folha" criticando a censura à peça “O Berço de Herói”. O escritor, relatava o SNI, recebera em um encontro nacional patrocinada pelo governo do Distrito Federal um prêmio de Cr\$90 mil por sua peça "O Último Carro". No discurso, não poupara críticas ao cerceamento à liberdade de expressão e acusara o governo de "o estar usando como inocente útil, na tentativa de provar que não existe censura no País".

Ficava cada vez mais dificil acreditar no fim da censura ou ao menos em seu abrandamento. Um novo concurso para censores foi aberto, com a inscrição de 5.000 candidatos para 58 vagas. Nota na "Folha de S.Paulo" de 2 de agosto anunciava que, na

442 Ibidem 
prova, os candidatos deveriam correr 2.000 metros em 12 minutos e se submeter a testes de nível universitário. Era preciso ter curso superior para pleitear o cargo de técnico de censura, com a atrativa remuneração mensal de Cr\$ 6.500, quase seis vezes o valor do salário mínimo da época, além de $20 \%$ de adicional pelo diploma superior, auxílio moradia, transporte e gratificação quinquenal. Os selecionados fariam um curso preparatório de seis meses em Brasília ${ }^{443}$. O primeiro concurso para censor havia sido realizado em 1974, em plena época da promessa de "abertura", e o segundo, em 1975, ano da censura a "Roque Santeiro". Antes, os censores eram "convidados" a exercer a função, e os concursos públicos, com provas psicotécnicas inclusive, foram uma tentativa de tirar a pecha que esses profissionais tinham de despreparados ${ }^{444}$. Dias Gomes foi um dos que os acusaram de não "primar pela inteligência"445.

Além de reforçar o time de censores, o governo seguia nesse ano de 1977 com a pressão para "expurgar" dos veículos de comunicação quem considerava inconveniente. Um episódio importante envolveu Lourenço Diaféria, da "Folha", preso em setembro por ordem do ministro do Exército, Sylvio Frota, representante da linha dura e aspirante a sucessor de Geisel. O "crime" do jornalista foi ter escrito a coluna "Herói. Morto. Nós”446, em que comparava a Duque de Caxias um sargento que morrera ao pular em um poço de ariranhas para salvar um garoto de 14 anos. “... Eu digo, com todas as letras: prefiro esse sargento herói ao Duque de Caxias", escreveu, em uma sequência que soou provocativa ao regime.

O Duque de Caxias é um homem a cavalo reduzido a uma estátua. Aquela espada que o duque ergue ao ar aqui na Praça Princesa Isabel -onde se reúnem os ciganos e as pombas do entardecer- oxidou-se no coração do povo. O povo está cansado de espadas e de cavalos. O povo urina nos heróis de pedestal. [...] No instante em que o sargento -apesardo grito de perigo e de alerta de sua mulher- salta no fosso das simpáticas e ferozes ariranhas, para salvar da morte o garoto que não era seu, ele está ensinando a este País, de heróis estáticos e fundidos em metal, que todos somos responsáveis pelos

\footnotetext{
${ }^{443}$ Cinco mil disputam 58 vagas de censores. Folha de S.Paulo, 2/8/1977, p. 6 [matéria não assinada]; para o valor do salário mínimo do País à época, de Cr\$1.106,40, tabela da Pró-Reitoria de Administração e Finanças da Universidade Estadual de Londrina, disponível em http://www.uel.br/proaf/informacoes/indices/salminimo.htm (acesso em 18/5/2016).

${ }^{444}$ KUSHNIR, Beatriz. Cães de Guarda - Jornalistas e censores do AI-5 à Constituição de 1988. São Paulo: Boitempo, 2004, p. 184-185

445 GOMES, Dias. Apenas um subversivo. Rio de Janeiro: Bertrand Brasil, 1998, p. 276-277

446 DIAFÉRIA, Lourenço. Herói. Morto. Nós. Folha de S.Paulo, 1/9/1977, p. 44
} 
espinhos que machucam o couro de todos.

Esse sargento não é do grupo do cambalacho.

Esse sargento não pensou se, para ser honesto para consigo mesmo, um cidadão deve ser civil ou militar. Duvido, e faço pouco, que esse pobre sargento morto fez revoluções de bar, na base do uísque e da farolagem, e duvido que em algum instante ele imaginou que apareceria na primeira página dos jornais. [...] O povo prefere esses heróis: de carne e sangue. ${ }^{447}$

A "Folha" noticiou a prisão e decidiu, como forma de protesto, publicar em branco o espaço da coluna de Diaféria. Com essa reação, o jornal acabou pressionado pelo ministro Armando Falcão, e teve de afastar Cláudio Abramo do cargo de diretor de Redação. Como pontuou a pesquisadora Beatriz Kushnir, nesse período, “o governo Geisel segurava a bandeira do fim da Censura com um mão e aumentava a máquina censória com a outra" ${ }^{448}$.

No mês do episódio Diaféria-Abramo, Dias Gomes voltaria a condenar publicamente a Censura e sua falta de critérios. Ao "Correio do Povo", edição do dia 14 de setembro, afirmou que "a realidade brasileira é tão absurda" que o governo havia proibido "Roque Santeiro", uma novela "igual a todas" que ele já havia escrito. "Se proibiram aquela, deveriam ter proibido todas as outras" ${ }^{449}$, provocou.

Em 1978, seria vetado o programa sobre a burguesia, sua primeira tentativa de criar algo diferente das novelas na TV. Nesse caso, o cerceamento mostrava outra faceta, a do silêncio, invertendo o sinal do ditado que diz "quem cala consente", no caso da Censura, "quem cala proíbe". A DCDP simplesmente não respondeu ao pedido de classificação etária da Globo. Com isso, Dias Gomes foi obrigado a voltar às novelas. Em julho, em reportagem que anunciava o lançamento de "Sinal de Alerta", o "Jornal do Brasil" escreveu que o programa da classe média havia sido "arquivado pela Censura", que "até hoje não se dignou a dar uma resposta sobre os textos enviados". O autor comentou a proibição:

No último ano trabalhei num projeto que, se tivesse saído, certamente apontaria um novo caminho para a televisão brasileira, através da

\footnotetext{
${ }^{447}$ Ibidem

${ }^{448}$ KUSHNIR, Beatriz. Cães de Guarda - Jornalistas e censores do AI-5 à Constituição de 1988. São Paulo: Boitempo, p. 204

${ }^{449}$ Dias Gomes: Escrever para a televisão é viver entre a sanidade e a loucura. Correio do Povo, 14/9/1977 [matéria não assinada]
} 
história da nossa classe média, desde 1720 até os nossos dias. "Os Grandes Sonhos dos Nossos Pequenos Burgueses", uma tele-história, ficou apenas no papel (em um canto do seu escritório há um monte de pastas onde estão guardados estes trabalhos)já que depois de dois meses de ter sido enviado para a Censura não obtivemos resposta. Então formos obrigados a parar, pois embora a censura não fosse oficial não seria conveniente ins istir. A emis sora tinha dado inteira liberdade pois era uma experiência que não visava a ibope. Eu mesmo não sabia o que ia acontecercom o projeto, pois poderia ser levado ao ar uma vez por semana, durar uma hora, não sei, mas certamente seria um novo caminho. E infelizmente uma coisa tão bonita, tão ambiciosa, ficou só no papel. Por isso reafirmo sempre que o problema não é da televisão em si mas das forças que cerceiam o seu desenvolvimento. Chegaram a ficar prontos 13 episódios, cada um deles focalizando determinado momento da vida brasileira, mas até hoje não sei o que a Censura pensa do programa e tive então que partir para outro trabalho, pois fiquei trabalhando seis meses nesse projeto. ${ }^{450}$

Ele também voltava, nessa mesma entrevista, a condenar a proibição a "Roque Santeiro": "Evidentemente foi uma frustração, me causou revolta, porque é inclusive a novela [de] que mais gosto" 451 . Em "Sinal de Alerta", retomava a crítica aos problemas da vida moderna, do progresso, a exemplo do que fizera em “Espigão". Seu foco mais específico na nova trama foi a poluição do ar. Depois de ter assumido estar cansado das telenovelas, o dramaturgo voltava a defendê-las como forma de "desenvolver a consciência" do telespectador, "fortalecer um opinião, obrigando, enfim, o governo a tomar providências", ainda que admitisse que "o comportamento da sociedade de consumo, em qualquer setor", seja no teatro ou na TV, é "absorver a contestação, transformando-a em artigo consumível e tirando-lhe o conteúdo revolucionário" ${ }^{\text {"42 }}$. Em uma entrevista que concedeu nessa época a "Encontros com a Civilização Brasileira", repetiu que sua temática televisiva era a mesma do teatro:

“Em alguns casos, como 'O Bem-Amado' e 'Bandeira 2', não passam de meras transposições, ou traduções, para um nova linguagem, de

\footnotetext{
450 ARAGÃO, Diana. Sinal de Alerta, de Dias Gomes - Uma novela sobre o direito de viver. Jornal do Brasil, 31/7/1978

451 Ibidem

452 Movimento, 7/8/1978, p. 19, apud. SACRAMENTO, Igor Pinto. Nos tempos de Dias Gomes - A Trajetória de um intelectual comunista nas tramas comunicacionais, doutorado na UFRJ, 2012, p. 358
} 
temas já explorados no palco. 'O Espigão' tinha 'O Túnel' como ponto de partida. 'Roque Santeiro', que foi proibida, girava dentro do universo comum a ‘O Pagador de Promessas', a 'Revolução dos Beatos' e 'O Berço do Herói’”, 453

"Sinal de Alerta" chegava ao fim (o último capítulo iria ao ar em 26 de janeiro de 1979) quando o autor foi surpreendido com votos de um "péssimo Natal" ao abrir sua caixa de correspondências. Era um cartão postal que reproduzia uma tela do pintor comunista Dmitriy Nalbandián, “Lenin em Gorki”, retrato realista do líder soviético. A mensagem dizia ser do Comando de Caça aos Comunistas, cuja atuação envolvia atentados, sequestros e mortes:

Sabemos que você é do Comitê Cultural do PCB, e agora está no C.B.D. Por que você não assume, como o Oscar? Ele é mais corajoso que você? Cuidado, pois você entrou em nossa relação.

O Comando de Caça aos Comunistas deseja a você, ativista da canalha comunista, um péssimo Natal e que se realize no ano de 1979 nosso confronto final. ${ }^{454}$

É provável que o C.B.D. mencionado por esse recado assustador seja Centro Brasil Democrático, que não utilizava essa sigla, e sim Cebrade. A associação foi fundada por iniciativa de Oscar Niemeyer (certamente o "Oscar" a que o cartão se refere), Ênio Silveira e Sérgio Buarque de Holanda, conforme havia registrado um documento da Agência Central do SNI de 13 de setembro daquele ano ${ }^{455}$. Difundido para todas as regionais do SNI, além das inteligências do Exército, Marinha e Aeronáutica, trazia como anexos o projeto de trabalho do Centro Brasil Democrático (promover seminários de defesa dos direitos humanos e da anistia, entre outros planos) e uma relação dos que assinaram o manifesto de fundação. Dias Gomes estava entre as quase 150 personalidades signatárias. O SNI parecia não deixar passar nada. Em 1977, além de incluir o dramaturgo no documento sobre a infiltração comunista nos veículos

\footnotetext{
453 Ibidem

${ }^{454}$ Cartão postal encontrado e reproduzido pela autora nos arquivos que estavam em poder da viúva de Dias Gomes na ocasião dos dois encontros emsua casa, no Rio, para a coleta de material para esta pesquisa; está sem data.

455 SNI, Agência Central, Informação nº 0707/19/AC/78, 13/9/1978
} 
de comunicação, anotara até um pedido de viagem desse "elemento" à França ${ }^{456}$. Em 1978, se somaram ao registro de sua participação no Cebrade outros que apontaram sua indicação para o conselho de televisão do $\mathrm{MIS}^{457}$, atuação no Instituto Cultural BrasilUnião Soviética $^{458}$ e a contribuição financeira à Convergência Socialista ${ }^{459}$.

A acusação do sinistro cartão postal de que Dias Gomes não teria coragem de assumir a participar no Centro Brasil Democrático era injusta. No final de janeiro de 1979, ele foi a Salvador para instalar a seccional baiana da associação e deu entrevista ao "Jornal do Brasil"460. Mostrava-se otimista, acreditava que o País estava "saindo do túmulo e pela primeira vez vendo alguns raios de sol". Falou sobre a expectativa da anistia política, que estava fortemente em pauta desde 1977, quando o movimento estudantil voltara às ruas, e a demissão do ministro do Exército, Sylvio Frota, por Geisel abrira caminho para uma transição negociada para a volta da democracia. Para o dramaturgo, "as anunciadas aberturas", contudo, ainda não haviam se concretizado na área cultural. Não haviam chegado ao teatro, afirmou, muito menos à televisão.

A esperança de Dias, apesar de comedida, também estava relacionada à anulação do AI-5 a partir de $1^{\circ}$ de janeiro daquele ano de 1979 (decretada por uma emenda constitucional apresentada pelo governo e aprovada pelo Congresso) e à sucessão presidencial. O general João Figueiredo, escolhido por Geisel para seguir com o processo de abertura, assumiria a presidência no dia 15 de março e diria: "Reafirmo: é meu propósito inabalável (...) fazer deste País uma democracia". Pouco mais de um ano antes, em reportagem da revista "Veja", Dias Gomes havia sido um dos chamados a opinar sobre Figueiredo, ao lado de Chico Buarque, Jorge Amado, Fernanda Montenegro e outros. Dissera não conhecer o general e não gostar de falar de coisas ilegítimas, como a eleição indireta que deveria colocá-lo no poder, mas concordara que poderia apoiá-lo com uma lista de condições, e a primeira era o fim da censura:

Se ele pretende pôr fim à censura, restituir ao povo brasileiro o direito de escolher seus governantes, dar liberdade aos sindicatos, promover a anistia de todos os atingidos por atos de arbítrio desde 1964, extinguir o AI-5 sem substituição pelas tais salvaguardas, abolir as prisões ilegais e torturas

\footnotetext{
${ }^{456}$ Ministério da Justiça, Divisão de Segurança e Informações, Informação no 588/77/DSI/MJ, 14/7/1977

457 SNI, Agência Rio de Janeiro, Informação nº 066/116/ARJ/78, 7/7/1978

458 SNI, Agência Rio de Janeiro, Informação no 79/320/ARJ/78, 21/8/1978

${ }^{459}$ Ministério do Exército, IV Exército, 0003/79, 29/11/1979

460 Teatrólogo anseia por abertura. Jornal do Brasil, 29/1/1979 [matéria não assinada]
} 
em locais ignorados, possibilitar aos estudantes a participação na via política, fazer enfim desta nação uma terra onde se respire democracia e liberdade. Se ele aceitar cumprir tudo isso, então estou com ele. Pode escrever que eu assino e depois cumpro. 461

Não seria tão simples chegar a essa "terra onde se respira democracia e liberdade", e o próprio Figueiredo, como ressaltou o livro "Brasil: uma biografia", era "didático" nesse sentido. Antes de assumir a Presidência, ao ser questionado pela imprensa sobre a volta da democracia, explicara: "Nós temos a laranja-lima, a laranjapera, a laranja-baía, que têm sabores diferentes, mas nem por isso deixam de ser laranjas [...] Assim também há democracias diferenciadas”. Ainda mais pedagógica foi sua resposta sobre a possibilidade da volta das eleições diretas: "Me respondam, o povo está preparado para votar? [...] O brasileiro pode votar bem se ele não conhece noções de higiene?" 462

A pressão da sociedade, contudo, era grande, e nesse início de 1979 a campanha pela anistia "ampla, geral e irrestrita" ganhou as ruas. Após tensa negociação, a lei 6.683 foi promulgada em 28 de agosto de 1979, anistiando, além dos militantes de esquerda, torturadores e assassinos a serviço das Forças Armadas. Em 20 de outubro, houve festa no aeroporto do Galeão para a chegada do líder comunista Luís Carlos Prestes após oito anos de exílio em Moscou. Contudo, o processo lento, gradativo e seguro da abertura estava longe de desativar os serviços de informação dos militares. A manutenção dos órgãos de segurança e inteligência foi, aliás, uma exigência do governo na transição negociada para a saída dos militares ${ }^{463}$. Assim, um livreto de oito páginas sobre Prestes vendido no aeroporto do Galeão a Cr\$10 na volta de líder comunista ao País tornou-se alvo do SNI, que registrou no material a participação de Dias Gomes, além da de Ziraldo, Ferreira Gullar, Sobral Pinto e Oscar Niemeyer ${ }^{464}$. Nesse mesmo ano, entrariam ainda para a coleção de citações ao dramaturgo no SNI uma menção a ele em depoimentos de $\operatorname{presos}^{465}$, a presença na instalação do Cebrade da Bahia ${ }^{466}$, sua atuação

\footnotetext{
${ }^{461}$ Para a maioria, Figueiredo é desconhecido. Veja, 11/1/1978, ed. 488, p. 58 [matéria não assinada] 462 SCHWARCZ, Lilia M. e STARLING, Heloisa M. Brasil: uma biografia. São Paulo: Companhia das Letras, 2015, p. 470

463 Ibidem para a exigência dos órgãos de segurança e manutenção.

464 SNI, Agência Central, Informe no 2295/31/AC/79, 23/10/1979

465 SNI, Agência de São Paulo, Informe no 0018/116/ASP/1979, 5/1/1979

466 SNI, Agência de Salvador, Informação nº 0071/116/ASV/79, 13/7/1979
} 
em favor "das esquerdas" ${ }^{467}$, a participação na noite de autógrafos de Miguel Arraes ${ }^{468}$ e em um debate sobre censura ${ }^{469}$. Esse evento, realizado na Casa do Estudante Universitário, no Rio, foi organizado pela Comissão de Luta Permanente pela Liberdade de Expressão e concentrou-se mais no campo do teatro. O dramaturgo falou da censura desde o Estado Novo como um "obstáculo à liberdade e à criatividade teatral". Seguiu seu tom de otimismo, contudo, afirmando que "apesar de todos os obstáculos e barreiras, o teatro brasileiro está sobrevivendo às ditaduras".

Fora dos palcos desde 1970, quando "O Bem-Amado" foi encenada, havia conseguido lançar apenas em livro uma nova peça, "As Primícias”, em 1978. Mas naquele ano de 1979 retomou a carreira teatral. Com o término de "Sinal de Alerta", no dia 26 de janeiro, a Globo pôs fim à exibição de telenovelas às $22 \mathrm{~h}$, e Dias iniciou a coordenação de um novo seriado, "Carga Pesada", que estrearia em maio no pacote "Séries Brasileiras", com "Malu Mulher", "Caso de Polícia" e "Aplauso". Esta última seria substituída no ano seguinte pela série "O Bem-Amado", uma continuação da novela de 1973.

A nova função de Dias na TV era bem menos exaustiva. Além de o seriado ser semanal, o autor contava com a colaboração de Gianfrancesco Guarnieri, Walter George Durst e Carlos Queirós Telles. Pôde, então, retornar ao palco em grande estilo, com uma "superprodução milionária” em parceria com Chico Buarque e Francis Hime, conforme noticiou "O Globo"470. Nas reportagens sobre a estreia do musical "O Rei de Ramos", que reinaugurava o teatro João Caetano, no Rio, o dramaturgo aproveitava para falar de censura e lembrar "O Berço do Herói”.

A partir do momento em que a própria realidade brasileira passou a ser proibida nos palcos, o tipo de teatro que eu vinha fazendo automaticamente tornou-se também proibido. Compreendi que eu não tinha mais vez, que seria impossível continuar a tentar sobreviver de teatro. Uma peça minha, "O Berço do Herói”, já havia sido proibida na noite da estreia;

\footnotetext{
${ }^{467}$ Ministério dos Transportes, Divisão de Segurança e Informações, Informação $n^{\circ}$ 575/SICI/DSI/MT/79, 3/9/1979

468 SNI, Agência Central, Informe n ${ }^{\circ} 2270 / 31 / A C / 79$

${ }^{469}$ SNI, Agência Rio de Janeiro, Informação no 043/119/ARJ/79, 19/4/1979

${ }^{470}$ MARINHO, Flavio. A volta de Dias Gomes ao teatro - Uma comédia musical, 'O Rei de Ramos'.

Parceiro: Chico Buarque. O Globo, 11/03/1979; a peça foi financiada com verba do governo estadualdo Rio, Cr\$ 2,4 milhões, através da Fundação de Teatros do Rio de Janeiro (Funterj): SACRAMENTO, Igor Pinto. Nos tempos de Dias Gomes - A Trajetória de um intelectual comunista nas tramas comunicacionais, doutorado na UFRJ, 2012, p. 364
} 
depois, "A Invasão" também foi interditada; as outras peças eram proibidas aqui e ali; eram encenadas num Estado, não eram em outros. Com o advento do AI-5 e o estabelecimento de uma ditadura rígida, eu percebi que, vivendo de teatro, ia morrer de fome. ${ }^{471}$

Nessa retomada dos palcos, experimentava um caminho bem conhecido, mas com sinal invertido. Se todas as suas novelas de TV haviam sido adaptações de peças de teatro ou ao menos se inspirado nelas, "O Rei de Ramos" se baseava na telenovela "Bandeira Dois", em torno do universo do jogo do bicho. Ao aproveitar o sucesso na TV, inclusive com parte dos atores, como Paulo Gracindo (que fizera o bicheiro Tucão na TV e agora vivia o Mirandão no teatro), atingiu um público de 60 mil pessoas em dois meses, recorde do teatro brasileiro de acordo com o "Jornal do Brasil" 472 . O retorno ao teatro foi tão bem-sucedido que ele lançou a versão da peça em livro, e "O Pagador de Promessas" foi remontada, com direção de Rangel novamente, 19 anos após seu lançamento. Nas entrevistas para falar de todos esses projetos, a censura era um assunto inevitável. À "Veja", afirmou acreditar que "O Rei de Ramos", que havia sido liberada sem cortes, teria sido vetada se encaminhada aos censores um ano antes. Assim, demonstrava acreditar no processo da abertura, apesar de admitir que o fato de a obra ser musical "amenizava" seu teor político, que era mais fácil obter autorização para um texto novo do que a liberação de um já proibido, e que, "por enquanto", só ouvia "palavras bonitas". "Quero acreditar nessas palavras, quero que os homens sejam obrigados pelo povo a cumpri-las" $" 473$.

No final de julho, o ministro da Justiça, Petrônio Portella, que substituíra Armando Falcão a partir da posse de Figueiredo, encaminhou à Presidência o ato que finalmente tiraria do papel o Conselho Superior de Censura (CSC), criado por lei havia 11 anos, poucos dias antes da assinatura do AI-5. O CSC tinha o poder de rever as decisões da Divisão de Censura de Diversões Públicas (DCDP) e foi composto por 12 membros, entre representantes da sociedade civil, como Ricardo Cravo Albim, pela Abert (Associação Brasileira de Emissoras de Rádio e TV), e Roberto Pompeu de

\footnotetext{
${ }^{471}$ Ibidem

${ }^{472}$ Dias Gomes lança amanhã o livro “O Rei de Ramos”. Jornal do Brasil, 31/5/1979 [matéria não assinada]

${ }^{473}$ MACIEL, Luís Carlos. Guerra de majestades. Veja, ed. 550, 21/3/1979
} 
Souza, da ABI (Associação Brasileira de Imprensa), além de membros do governo indicados, por exemplo, pelos ministérios das Comunicações e das Relações Exteriores. O CSC, contudo, não tinha ingerência sobre decisões relacionadas à televisão, e seu poder era limitado também para outras produções artísticas. Era hierarquicamente vinculado ao Ministério da Justiça, e qualquer decisão que não fosse unânime deveria ser submetida ao ministro. Assim, passou a ter atuação ambígua, ora considerado um avanço na conquista da liberdade de expressão, ora um retrocesso. No início de 1980, por exemplo, colocaria fim à censura de quase uma década ao musical "Calabar", de Chico Buarque (ainda que tenha determinado a classificação para 14 anos, a liberação foi sem cortes). Já um ano depois, em janeiro de 1981, referendaria a exigência da Censura de quatro cortes no filme "Estado de Sítio", do grego Costa Gravas. Um deles a do close na bandeira do Brasil em uma aula de tortura ${ }^{474}$.

A máquina censória seguia sendo reforçada, com um novo concurso para a contratação de técnicos em 1979 (outro seria realizado em 1980) ${ }^{475}$. Tudo isso no momento em que o discurso oficial falava em volta da liberdade de expressão. Pelo sim, pelo não, a Globo decidiu fazer uma nova tentativa de liberar "Roque Santeiro", decisão recebida por Dias Gomes com "espanto e ceticismo", segundo reportagem da "Tribuna da Imprensa", de 14 de setembro daquele 1979:

A verdade é que o processo de abertura na televisão ainda é muito pequeno e pressões se sobrepõemde todos os lados. Não acredito que possa haver uma guinada radical exatamente em função do meu ceticismo em relação à abertura política vigente. Esta abertura é apenas uma pequena fresta, ao lado de fora muito escuro, nublado.

$[\ldots]$

O Frota [ministro Sylvio Frota, representante da linha dura demitido por Geisel] já está reformado, mas há muitos outros Frotas por aí à espera de uma mudança. ${ }^{476}$

\footnotetext{
474 "Estado de Sítio" liberado com cortes. Folha de S.Paulo, 16/1/1981, p. 33 [matéria não assinada] ${ }^{475}$ As informações sobre o CSC e os concursos para censores estão em KUSHNIR, Beatriz. Cães de Guarda - Jornalistas e censores do AI-5 à Constituição de 1988. São Paulo: Boitempo, 2004, p. 126$127 ; 184$.

${ }_{476}$ Novela de D. Gomes pode ser liberada pela censura. Tribuna da Imprensa, 14/9/1979 [matéria não assinada]
} 
À reportagem da "Tribuna da Imprensa", Mário Lúcio Vaz, assistente de Boni, afirmou que a emissora aguardava "para os próximos dias" uma resposta da Censura. Ela chegou ainda naquele mês. E foi "não"477.

477 A informação sobre esse novo veto foi dada por Dias Gomes em entrevista à revista "Ele Ela", edição de setembro de 1979 [matéria não assinada]. 


\subsection{Capítulo 12}

\section{Democratura}

Mais um atentado da extrema direita contra um jornal foi registrado no início dos anos 1980. Desta vez, a vítima foi o nanico "A Trombeta", de Sucupira. Enquanto isso, o prefeito da cidade, Odorico Paraguaçu, estava preocupado com a alta inflação do País, que ultrapassou os $100 \%$ anuais, e levou à Brasília sua ideia para acabar com esse índice: aumentá-lo para $300 \%{ }^{478}$.

Essa é a história do episódio "O Atentado Pirotécnico", da série "O BemAmado". Com os mesmos personagens e atores do núcleo principal da novela exibida em 1973, o seriado entrou no ar em 22 de abril de 1980 e foi veiculado até 1984. Das entrelinhas e do realismo fantástico de suas produções televisivas anteriores, Dias Gomes passou a uma crítica mais direta dos problemas do País. Pouco mais de dois meses depois da estreia, reportagem da "Veja" atestava o sucesso, afirmando que a série marcava "uma nova fase na utilização de temas políticos na TV brasileira". "Depois de nortear os programas jornalísticos dos primeiros anos de 60, ser banida dos vídeos nos anos 70, esgotar-se nos humorísticos, ela [a política brasileira] estreia, enfim, na ficção", escreveu o jornalista Artur Xexéo ${ }^{479}$. A matéria citava outros programas que haviam passado a usar temas da realidade de forma mais direta, como a de um personagem da novela "O Todo Poderoso", da Bandeirantes, que havia participado da Guerrilha do Araguaia, e do protagonista de "Chega Mais", novela das sete da Globo, que escondia o seu passado como integrante da luta armada.

Dias Gomes testou esse caminho de forma muito mais radical no teatro, com “Campeões do Mundo", encenada pela primeira vez em 4 de novembro de 1980, no teatro Villa-Lobos, no Rio ${ }^{480}$. Se na TV, com “O Bem-Amado", seguia fazendo uso da comédia e da alegoria para representar a atualidade nacional, no palco o retrato era cru, direto. Ao comparar as duas obras, avaliou a diferença entre a televisão e o teatro:

\footnotetext{
${ }^{478}$ Para o episódio do atentado ao jornal, XEXÉO, Artur. O front global. Veja, ed. 673, 13/8/1989, p. 111; para o capítulo sobre a inflação, Dicionário da TV Globo - vol. 1: Programas de Dramaturgia \& Entretenimento. Rio de Janeiro: Jorge Zahar Editor, 2003, p. 394-395.

${ }^{479}$ XEXÉO, Artur. O front global. Veja, ed. 673, 13/8/1989, p. 111

${ }^{480}$ Para a data e o local de estreia de "Campeões do Mundo", SACRAMENTO, Igor Pinto. Nos tempos de Dias Gomes - A Trajetória de um intelectual comunista nas tramas comunicacionais, doutorado na UFRJ, 2012, p. 369
} 
“Campeões do Mundo" não é uma sátira. "O Bem-Amado” é. Pelo próprio caráter da televisão, apresenta uma análise superficial da realidade brasileira. Tão superficial quanto o próprio veículo que, ao contrário do teatro, se recusa a uma construção que não seja linear. Costumo comparar o trabalho em televisão à abertura de uma estrada, sempre horizontal. Lá pelo meio do caminho, como aconteceu com a nossa Transamazônica, o começo já es tá todo coberto de mato. Já no teatro o trabalho é vertical. Tem muito a ver com arquitetura. ${ }^{481}$

A peça girava em torno de diversos aspectos da vida política brasileira entre o golpe de 1964 e a anistia, em 1979. Começava com a volta de um exilado que fora anistiado, e, em "flashback" mostrava o motivo de seu exílio: a participação no sequestro do embaixador norte-americano. Tinha cenas de uma participante da luta armada sendo torturada por militares, discussões sobre o papel do PCB na oposição e até uma reflexão a respeito da disputa entre operários e intelectuais de esquerda. Era baseada no sequestro do embaixador Charles Burke Elbrik, ocorrido em 1969, mas continha referências aos sequestros do embaixador alemão Von Holleben e o do suíço Giovanni Eurico Bücher, ambos realizados em 1970. No enredo, a ação acontecia no mesmo dia em que o Brasil se sagrava tricampeão na Copa do Mundo, em 1970, com a vitória no futebol ofuscando a repercussão do ato político.

A liberação de tão forte temática pela Censura transformou a peça em um evento político, como pontua o doutorado de Sacramento a respeito da trajetória artística de Dias Gomes.

[O crítico de teatro de "O Globo"] Flavio Marinho destacou o fato de "Campeões do Mundo" ser o "primeiro sinal evidente" de que "a liberdade de expressão" voltava a ser exercida como não se via há muito tempo. [O colunista do "Jornal do Brasil"] Yan Michalski comemorou que as "asas da abertura" permitiram que houvesse a primeira peça a abrir os caminhos para que o teatro pudesse voltar a falar "de maneira direta e abrangente dos tempos mais em que não se podia falar". ${ }^{482}$

\footnotetext{
${ }^{481}$ Dias Gomes, lutando contra a censura. Com bom humor. Jornal da Tarde, 22/6/1981, p. 23 [matéria não assinada] 482 SACRAMENTO, Igor Pinto. Nos tempos de Dias Gomes - A Trajetória de um intelectual comunista nas tramas comunicacionais, doutorado na UFRJ, 2012, p. 369-370
} 
"O Bem-Amado" e "Campeões do Mundo" eram, sem dúvida, dignas de comemoração. Mas também podem ser vistas como simbólicas do quão nebuloso foi o processo da abertura política, com um oscilatório movimento da Censura. Em junho, meses antes da estreia da peça, Dias Gomes, ao falar dela em uma entrevista, dissera que sentia "muito pouco" os "ventos da abertura". "Na realidade, a abertura é uma fresta pela qual espiamos o mundo lá fora. Ainda não é uma abertura que satisfaça e que necessita ser consolidada." ${ }^{\prime 83}$ E a fresta se fechou cinco meses após a estreia de "Campeões do Mundo", quando censores estiveram na porta do teatro para intimar Dias Gomes a comparecer à Divisão de Censura de Diversões Públicas. Ao jornal "O Globo", o dramaturgo afirmou que dois meses depois do lançamento da peça, a Censura havia pedido dois cortes. Como o espetáculo já estava em cartaz, as mudanças não foram feitas, e o dramaturgo achou que "eles tivessem relevado". Segundo ele, todos os cortes se referiam a questões políticas. "Causa estranheza que cinco meses depois a Censura venha exigir esses cortes", declarou ao jornal. "Vou pedir para manter a peça como está. Cortar esses trechos é como cortar o dedo de uma pessoa. Ela continuaria vivendo, mas sem uma parte importante", comparou ${ }^{484}$. Pois a Censura optou por cortar os dedos, e o dramaturgo, por informar ao público, a cada apresentação, sobre a parte decepada. A leitura dessa nota "fazia muito sucesso entre a plateia", conforme relatou o autor ao "Jornal da Tarde", quando deu entrevista sobre o lançamento do espetáculo no Teatro Brigadeiro de São Paulo (no Rio, havia sido visto por 90 mil pessoas). Na temporada paulistana, a Censura implicaria até com "cacos" dos atores ${ }^{485}$.

Esse problema essencialmente político [da censura] relembra outros tempos. É preciso aprender a reconhecer os sinais e reagir contra eles. Uma vez a gente pode ser apanhado desprevenido. Duas, já é burrice. Por isso é que "Campeões do Mundo" presta um grande serviço. Vendo a peça, pode-se refletir sobre os erros cometidos, e não cometê-los novamente. Vamos errar, mas pelo menos sejamos criativos. ${ }^{486}$

\footnotetext{
${ }^{483}$ Por uma fresta, Dias Gomes espia a liberdade e o mundo lá fora. Tribuna da Imprensa, 26/6/1980 [matéria não assinada]

${ }^{484}$ Corte em peça leva Dias Gomes à Censura. O Globo, 19/3/1981, p. 12 [matéria não assinada]

${ }^{485}$ Dias Gomes, lutando contra a censura. Com bom humor. Jornal da Tarde, 22/6/1981, p. 23 [matéria não assinada]; para a informação sobre os "cacos", que são as improvisações feitas no espetáculo, ALMEIDA, Miguel. Um escritor com os olhos na rua. Folha de S.Paulo, 27/6/1981, p. 52. ${ }^{486}$ Dias Gomes, lutando contra a censura. Com bom humor. Jornal da Tarde, 22/6/1981, p. 23 [matéria não assinada]
} 
A mesma reportagem relatava dificuldades semelhantes enfrentadas em "O BemAmado", e Dias negou então uma declaração do ministro da Justiça, Ibraim Abi-Ackel (que entrara no cargo após a morte de Petrônio Portella, em janeiro de 1980), de que não havia censura na televisão. Os cortes à série eram tantos que, em vez de escrever os episódios com uma hora de duração cada um, como iam ao ar, o autor os fazia com uma hora e meia, prevendo já possíveis tesouradas. Duas delas, daquele 1981, foram relatadas por ele ao jornal: Em um episódio, o prefeito de Sucupira dava entrevista na TV e, "lá pelas tantas", conforme contou Dias, "um dos entrevistados pergunta o que Odorico acha do Maluf. E ele responde que o governador só tem um defeito: 'Ele vive me imitando'." Em outra ocasião, pediram a Odorico para explicar o que era o regime de democratura: "É um regime que conjumina as merescendências da democracia com os taqualmentes da ditadura. Na democracia, o povo escolhe a gente, os governantes. $\mathrm{Na}$ democratura, a gente escolhe o povo que vota na gente" ${ }^{987}$. Em 1982, ganharia repercussão um corte exigido pela Polícia Federal da seguinte frase do prefeito: 'Não tivesse eu jurado fazer de Sucupira uma democracia, mandava botar todos eles num pacote e jogava no mar"488.

A Divisão de Censura de Diversões Públicas (DCDP) também refletia as ondas oscilantes da abertura. Rogério Nunes, que dirigia a divisão desde 1972 e assinara o veto a "Roque Santeiro", havia sido exonerado em 1979. Como sinal de mudança, o ministro Portella indicou para o cargo o jornalista José Vieira Madeira, que já trabalhara em "O Globo" e no "Dia" e era considerado mais "liberal". Já Abi-Ackel o trocou em 1981, como conta a historiadora Beatriz Kushnir, pela "legítima representante da linha dura", Solange Hernandez. Apelidada de Solange Tesourinha, pela sua vocação para cortar obras, passou a exigir relatórios dos censores e anulou a decisão de três técnicos, entre eles Coriolano Fagundes (o autor do "manual da Censura"), de liberar o filme "Pra Frente, Brasil', de Roberto Farias, que falava da luta armada e continha cenas de tortura. Admitiu à imprensa em 1982, quando finalmente autorizou a exibição do longametragem, que havia sumido com os pareceres de autorização da obra porque estava

\footnotetext{
${ }^{487}$ Ibidem

${ }^{488}$ Dicionário da TV Globo - vol. 1: Programas de Dramaturgia \& Entretenimento. Rio de Janeiro: Jorge Zahar Editor, 2003, p. 395
} 
preocupada com a saúde mental da população ${ }^{489}$. Para a TV, sua gestão foi um "Deus nos acuda", na lembrança de Boni: "Dona Solange via pornografia em tudo que era lugar!" $" 490$.

Apesar de no governo Figueiredo terem-se iniciado as discussões para que a censura passasse a ser apenas classificativa (ou seja, nenhuma obra seria cortada, mas classificada para uma determinada faixa etária), concentrada na "moral e nos bons costumes", não há dúvida de que o viés político-ideológico não fora abandonado ${ }^{491}$.

A pressão sobre "O Bem-Amado" fez com que a Globo cogitasse cancelar a série, apesar do enorme sucesso de audiência. Foi quando Dias Gomes passou a abordar a censura dentro de uma lógica de mercado, num raciocínio fortemente liberal, ao afirmar ao "Jornal do Brasil", em junho de 1981, que, "se o espectador não gostar, o programa não terá audiência e sairá do ar". Assim, argumentou, "não é através da censura que vamos resolver moral ou bons costumes, pois a própria sociedade tem seus mecanismos de defesa [...] Não é preciso chamar a polícia, pois vivemos num mercado, num sistema que recusa o que não dá certo". Conforme analisou o doutorado de Sacramento, "para desqualificar a censura, Dias Gomes acabou defendendo o poder de escolha do consumidor como soberano e autodeterminável numa sociedade capitalis ta" ${ }^{\prime 492}$.

A gravidade do cerceamento à série tinha como consequência o endurecimento da censura interna na Globo. E o autor, antes de brigar com os militares, tinha que lutar contra seus próprios colegas, conforme demonstra uma carta enviada a Boni em 21 de agosto de 1981, cuja cópia, guardada por Dias, foi obtida para esta pesquisa em 2011 nos arquivos do escritor em posse de sua viúva.

Na mensagem, o dramaturgo mescla um tom forte de reclamação com sua habitual ironia, abrindo com o termo "considerandos", a exemplo da tão característica linguagem de Odorico Paraguaçu.

\footnotetext{
${ }^{489}$ Para a troca de comando na DCDP e a censura do filme "Pra Frente, Brasil", KUSHNIR, Beatriz. Cães de Guarda - Jornalis tas e censores do AI-5 à Constituição de 1988. São Paulo: Boitempo, 2004, p. 204-205; para a duração do mandato de Nunes, MARTINS, William de Souza Nunes. Os filmes nacionais e a censura cinematográfica na década de 1970. Anais das Jornadas de 2007, Programa de Pós-Graduação em História Social da UFRJ, disponível em https://revistadiscenteppghis.files.wordpress.com/2009/05/william-martins-os-filmes-nacionais-e-acensura-cinematografica-na-decada-de-1970.pdf (acesso em 24/5/2016).

490 Entrevista de Boni à autora.

491 SACRAMENTO, Igor Pinto. Nos tempos de Dias Gomes - A Trajetória de um intelectual comunista nas tramas comunicacionais, doutorado na UFRJ, 2012, p. 380

492 Ibidem, p. 382-384
} 
Ilmo. Sr.

José Bonifácio de Oliveira Sobrinho

Perdoe-me usar a "mala direta" para expor uma situação que se agrava dia a dia. Primeiramente, vamos aos "considerandos":

1 - Acabo de ser informado de que o último episódio que escrevi para o seriado "O Bem-Amado" (“O Casamento do Século”) não será gravado por falta de verba.

2 - Comunicam-me também que os episódios “O Atentado Pirotécnico" (inspirado no atentado à "Tribuna da Imprensa") e "Sucupira, Ame-a ou Deixe-a" estão definitivamente proibidos pela censura interna. E que o episódio “Zeca Diabo, Cangaceiro de Deus” está sub júdice, também ameaçado de não ir ao ar. Quanto aos demais episódios, ninguém sabe se serão liberados.

3 - Além da falta de verba para realizar o episódio "O Casamento do Século”, a Direção Geral dos Seriados, segundo estou informado, levanta problemas de comportamento de personagens, assusta-se comfrases e alusões, mostra temores quanto a isso ou aquilo, levando a indecisão, a insegurança a todo o núcleo e particularmente a mim, que, sinceramente, não sei mais o que posso, o que devo ou não devo escrever.

4 - Esse clima leva cada funcionário da Globo, desde os mais escalonados aos mais humildes, a se transformarem num censor [grifo nosso]. Quando passo pelos porteiros, já temo que um deles me chame de lado e diga: "Olhe, vi no VT aquele episódio. Acho que você deve mudar aquela cena, aquilo não passa...” Por outro lado, ouço explicações delirantes como: “Toda semana está vindo um grupo de generais assistir o VT do 'BemAmado' na sala da Presidência”. Ou então: “O SNI avocou a si a censura do 'Bem-Amado"'. Qualquer dia desses vão me dizer que é o próprio general Figueiredo que censura cada episódio, antes da famosa reunião das nove. Mesmo achando que o Brasil é um País onde o Absurdo tem carteira de reservista e CPF, não vou a tanto...

5 - Todos os episódios acima referidos foram escritos dentro da linha traçada e aprovada pela Vice-Presidência de Operações. Não avancei nem recuei um milímetro. Mas, se eu não mudei, algo deve ter mudado. Por isso é que peço um esclarecimento, pois estamos chegando a um impasse, que pode estar sendo determinado por incompreensões, inseguranças compreensíveis 
ou temores exagerados. "O Bem-Amado" é um programa que se firmou na opinião pública justamente por saber ocuparo exíguo espaço concedido até agora à teledramaturgia no processo de abertura política do País. E ouso afirmar que a Globo the deve um conceito conquistado junto a um público mais exigente que cobra da tevê uma atitude crítica e inteligente ante a realidade brasileira [grifo nosso]. "O Bem-Amado" não pode sobreviver sem uma corajosa defesa do espaço conquistado. E o que estamos vendo é uma tendência suicida a abrir mão desse espaço.

Finalmente, acho que chegou o momento de "pedir tempo", como no basquete, para orientar o time.

Cordialmente, Dias Gomes

Os episódios mencionados na correspondência tiveram problemas também com a Censura Federal mas acabaram indo ao $\operatorname{ar}^{493}$. Entre as "explicações delirantes" que Dias menciona na tentativa de esclarecer o acirramento da censura interna, a avocação do SNI para o controle de "O Bem-Amado" não parece mesmo fazer sentido a partir da documentação do órgão levantada para esta pesquisa. Isso não quer dizer que a inteligência não se preocupasse com o seriado e que, a partir disso, pudesse ter exercido pressão sobre a DCDP. A primeira menção a "O Bem-Amado" aparece em mais um documento a respeito da "infiltração nos órgãos de comunicação social"494. Elaborado pelo CIE, o Centro de Informação do Exército, em 26 de maio de 1981, deixava surgir pela primeira vez dentre os documentos com citação a Dias Gomes a discordância entre as correntes mais brandas e mais duras, com reclamações em relação à atuação mais "liberal" da Censura.

O informe falava do "clima de abertura democrática" como "altamente promissor" para as forças de esquerda. A exemplo de outros documentos já mencionados nesta dissertação, traçava uma relação estratégica entre a derrubada da "moral e dos bons costumes" e a tomada de poder pelos comunistas, conforme trechos abaixo transcritos, em que há críticas à Censura:

\footnotetext{
493 Os episódios forma conferidos no site teledramaturgia.com.br, disponível em http://www.teledramaturgia.com.br/o-bem-amado-a-serie/ (acesso em 25/5/2016); não há um episódio chamado "Sucupira, Ame-a ou Deixe-a", mas as datas de exibição nos fazem deduzir que é "I love Sucupira", apenas com o título alterado.

${ }^{494}$ Ministério do Exército, Gabinete do Ministro, CIE, Informação no 295-S/103.1-CIE, 26/5/1981
} 
O momento [de abertura] faz com que a guerra psicológica do Movimento Comunista Internacional volte-se para as técnicas pacifistas, principalmente a utilização da psicologia e dos meios de comunicação de massa, através da propaganda, de forma intensiva e de maneira insidiosa, amoral e inescrupulosa, no sentido de influir sobre um grupo social, 뜨 tentativa de conduzi-lo à criação de um clima favorável à desmoralização dos valores tradicionais nacionalistas. Essa estratégia constitui-se em uma etapa preparatória à derrubada do regime, à tomada do podere à destruição da democracia [grifo nosso].

[...]

Tais fatos são agravados pela omissão da Censura e a não aplicação da legislação pertinente.

$[\ldots]$

Cresce maciçamente o número de publicações obscenas [...], explorando o erotismo e o sexo, expostas livremente nas bancas de jornais, pregando abertamente, a dissolução dos costumes e isentas de qualquer fiscalização pelos órgãos competentes. O noticiário colorido do último Carnaval, retratando mais uma orgia sexual do que uma festa cultural, mostra o nível que atingiu a tendenciosa exploração contracultural no País [...] e não sofreu nenhuma sansão ou mesmo críticas das autoridades responsáve is pela Censura. ${ }^{495}$

"O Bem-Amado" é mencionado em um subtítulo exclusivamente dedicado à televisão, em que Janete Clair volta a ser apontada como comunista e a Globo, como "principal instrumento do Movimento Comunista Brasileiro", além de novamente relacionar os "valores sagrados da família" à política:

A Rede Globo, um dos mais importantes "centros de irradiação cultural do País", através de seu departamento de telenovelas, dominado por comunistas notórios, como Janete Clair, Dias Gomes e outros, vem se transformando no principal instrumento do Movimento Comunista Brasileiro, no afã de destruir os valores mais sagrados da família brasileira, instilando de maneira insidiosa os "NOVOS VALORES" da sociedade, com relativo sucesso.

$\mathrm{O}$ aspecto mais pernicioso verifica-se na programação do chamado "horário nobre", com a apresentação de novelas como "Coração Alado",

${ }^{495}$ Ibidem. 
"Baila Comigo", "Bem-Amado" etc. montadas sem um mínimo de sentimento ético, apresentando aos telespectadores umsistemático endeusamento do adultério, do homoss exualismo, da promiscuidade e da corrupção.

A recente novidade chamada "Amizade Colorida" vem sendo incentivada através do aviltamento do sexo e da instituição do casamento. Crimes e taras de toda a natureza, como estrupo [sic], masturbação, lesbianismo, toxicomania são apresentados comnaturalidade, como se fossem fatos normais e corriqueiros de nossa sociedade, em proporções tais que a família tradicional seja considerada exceção. ${ }^{496}$

Na conclusão, o documento afirmava que a "omissão da censura tem estimulado a agressividade" e que "a guerra psicológica" da esquerda conduz a "um enfraquecimento dos valores tradicionais, necessários ao soldado brasileiro".

Poucos dias depois, em 2 de junho, é a vez de "O Bem-Amado" ser tema de um documento da Agência Central do SNI, que analisava detalhadamente o episódio " $\mathrm{O}$ Povo de Deus e o Milagre dos Coronéis", exibido em 19 de maio, sobre uma disputa de terras entre Odorico Paraguaçu e posseiros. Na resistência à desocupação imposta pela Prefeitura, há a participação da Comissão Pastoral da Terra. E o SNI concluiu que o autor "foi assessorado por clérigos da Comissão Pastoral da Terra, por conter detalhes que certamente escapariam à sua percepção" e se baseou em "fatos do cotidiano, com enfoque sensacionalista e tendencioso". O relatório realizou uma decupagem do capítulo, com cada cena atrelada à mensagem que, para o SNI, o autor quis passar. A seguir, alguns exemplos retirados do documento:

Cena: Jagunços queimam, a mando do prefeito, as benfeitorias dos poss eiros visando expulsá-los.

Mens agem: utilização de cargo público para a prática de violência. Abuso de autoridade.

Cena: o vigário e o padre italiano da Comissão Pastoral da Terra procuram o prefeito pedindo providências para que cessem as hostilidades contra os posseiros $(\ldots)$

Mens agem: a Igreja, ao atuar no campo social, está desempenhando uma de suas missões.

496 Ibidem 
Cena: o padre estrangeiro, da Comissão Pastoral da Terra, é acusado de comunista pelo prefeito, que pede providências para a polícia.

Mensagem: Os que defendem os injustiçados são acusados de comunistas.

Cena: os posseiros, mobilizados pelo vigário, pela imprensa e pelos políticos da oposição, fazem uma passeata e invadem a prefeitura para exigir a anulação do processo de expulsão do padre estrangeiro e a posse das terras. O prefeito, ameaçado por Zeca Diabo, armado de revólver, cede e manda distribuir uma pequena parte das terras aos posseiros; a polícia se omite e não impede a ação do povo.

Mens agem: $\underline{O \text { povo unido consegue os seus objetivos. A polícia não }}$ tem força para enfrentar a massa rebelada [grifo no original]. ${ }^{497}$

No início de 1982, foi detectada pelo Cisa, da Aeronáutica, uma entrevista de Dias Gomes ao jornal peruano "Marka", em que o autor fala da série ${ }^{498}$. O SNI voltou a "O Bem-Amado" em 13 de julho do mesmo ano para informar que o programa, de “críticas e sátiras ao Governo e ao Regime de 1964”, tinha tido sete episódios censurados, entre eles "Milagre dos Coronéis" e "Atentado Pirotécnico" (seriam posteriormente liberados, com cortes), os quais haviam sido publicados em forma de livro pelo autor, sob o título "Sucupira, Ame-a ou Deixe-a"499. Até sair do ar, em 9 de novembro de 1984, o seriado iria ser mais uma vez mencionado pela inteligência, também em informe sobre a "infiltração comunista", no qual Dias Gomes foi descrito, já no apagar das luzes do regime militar (em 9 de abril de 1984), como "militante do PCB" que "criou o personagem Odorico Paraguaçu, de 'O Bem-Amado"" 500.

Sua peça "Campeões do Mundo", no entanto, mereceu mais atenção do SNI nesses início da década de 1980 do que o seriado da TV. No primeiro informe a tratar da obra, em 11 de novembro de 1980, havia uma lista de todos os membros da equipe, do autor aos atores (entre eles Dênis Carvalho, Ângela Leal e Jonas Bloch), cenógrafos etc., com um resumo a esclarecer quem tinha vínculos "subversivos". Afirma va que o dramaturgo obrigou a parcela "não subversiva" a ler obras de Fernando Gabeira (participante do sequestro ao embaixador norte-americano, que inspirou os

\footnotetext{
497 SNI, Agência Central, Informação nº 0185/19/AC/81, 2/6/1981

498 Ministério da Aeronáutica, Cisa, Encaminhamento 0030/Cisa-RJ, 17/2/1982

499 SNI, Agência Rio de Janeiro, Informe no 095/116/ARJ/82, 13/7/1982

500 SNI, Agência Rio de Janeiro, Informação no 032/16/ARJ/84, 9/4/1984
} 
personagens), Che Guevara e Alfredo Sirkis (membro do grupo armado de Carlos Lamarca). Em 1981, o SNI iria se debruçar sobre a peça em mais cinco processos. Abordou o fato de comunistas notórios como Prestes e Niemeyer terem feito elogios ao espetáculo ${ }^{501}$, de estarem sendo realizados debates com a presença de membros do Partidão após as apresentações ${ }^{502}$ e de a encenação ignorar cortes exigidos pela Censura $^{503}$, inclusive fazendo disso propaganda da "subversão da ordem" 504 . Um último documento relatava que o Conselho Superior de Censura havia revogado, em 13 de agosto de 1981, os cortes determinados pela Divisão de Censura de Diversões Pública. A decisão do CSC fora unânime, não cabendo mais, lembrava o SNI, a interferência do ministro da Justiça. Foi anexada uma reportagem de "O Globo", de 14 de agosto, sobre a reunião do CSC, que informava que um seminário sobre Censura e Televisão promovido pelo conselho conclúra que o controle ao conteúdo deveria ser feito internamente pelas emissoras, a partir de um código de ética elaborado pela Abert (Associação Brasileira de Emissoras de Rádio e Televisão).

Enquanto a sociedade exigia a volta das liberdades democráticas, o governo escondia sob a promessa de abertura, mesmo nesses anos em que o regime militar agonizava, a ampla atividade de seus órgãos de segurança. É do início da década de 1980 a maior quantidade de documentos do SNI que mencionam Dias Gomes. Desde 1966, quando o dramaturgo apareceu pela primeira vez na papelada secreta, só em 1979 os registros sobre ele passaram de cinco por ano -foram sete. Em 1980 chegaram a nove e em 1981, a dez, com a vigilância seguindo alta até o último ano da ditadura (nove em 1982; seis em 1983 e cinco em 1984).

É interessante notar que o tipo de preocupação nesses últimos anos guardava semelhança com a fase inicial do regime. Grande parte aborda seu vínculo com o PCB, que seguiu em clandestinidade mesmo após 1979, quando o governo realizou a reforma partidária, autorizando a criação de novos partidos não comunistas. O gesto conciliava uma aparência "democrática" com a tentativa de dividir a força da oposição ${ }^{505}$. O SNI registrou o apoio de Dias Gomes, entre outros nomes vinculados ao candidato do

\footnotetext{
501 SNI, Agência Rio de Janeiro, Informação no 03301160A RJ/81, 23/2/1981

502 SNI, Agência Central, Informação no 018/16/AC/81, 10/3/1981

503 SNI, Agência Central, Informe no 0965/31/AC/81, 31/3/1981

504 SNI, Agência Central, Informe nº 0108/19/AC/81, 3/4/1981

505 NAPOLITANO, Marcos. 1964 - His tória do regime militar brasileiro. São Paulo: Contexto, 2014, p. 299-304
} 
PMDB Miro Teixeira ao governo do Rio, anexando manifesto de intelectuais defendendo a versão partidária do $\mathrm{MDB}^{506}$.

Foram sete os informes sobre sua participação no Centro Brasil Democrático ${ }^{507}$. Foi o Cebrade que organizou o show em $1^{\circ}$ de maio de 1981 , em comemoração ao Dia do Trabalho, no Riocentro, quando um atentado planejado pela extrema direita deu errado e a bomba explodiu no carro dos militares, matando um e deixando o outro ferido. O episódio tornou evidente a incapacidade do regime de administrar a abertura e, no campo da política, na avaliação das historiadoras Lilia M. Schwarcz e Heloisa Starling, significou o fim do governo Figueiredo, que sabia do plano do atentado havia um mês antes e nada fizera para evitá- $10^{508}$.

A documentação do SNI que menciona Dias Gomes nesse início de década também trata, entre outros assuntos, de sua readmissão na Rádio Nacional, uma consequência da Lei de Anistia ${ }^{509}$, e do tema que seguiu caro aos militares até o apagar das luzes da ditadura: a infiltração da oposição nos veículos de comunicação, em especial na televisão, o "veículo subversivo" de Chateaubriand. Nessa documentação, Janete Clair surge novamente como parceira de Dias Gomes em sua empreitada oposicionista, e é chamada "comunista notória" 510 , em cujas novelas são incutidas "a orientação marxista-leninista, combatendo o sistema político-sócio-econômico do País"511. Já Boni, o principal executivo da Globo, que recebera um "nada consta" em informes dos anos de chumbo, em 1982, foi considerado "esquerdista" pelo SNI, que registrou que "ele teria declarado, de uma feita, que a dupla [sertaneja] Dom \& Ravel não pisaria na TV Globo enquanto ele lá estivesse, pois a dupla costuma compor e cantar músicas patrióticas de apologia ao Brasil [como "Eu te amo, meu Brasil",

\footnotetext{
506 SNI, Agência Rio de Janeiro, Informação nº 073/116/ARJ/82

507 SNI, Agência Rio de Janeiro, Informação nº 017/116/ARJ/80, 23/1/1980; SNI, Agência Central, Informe $n^{\circ}$ 0181/31/AC/80, 23/1/1980; SNI, Agência Rio de Janeiro, Informação $n^{\circ}$ 023/116/ARJ/80, 28/1/1980; SNI, Agência Rio de Janeiro, Informação no 094/116/ARJ/80, 4/6/1980; SNI, Agência Rio de Janeiro, Informe $n^{\circ}$ 039/116/ARJ/82, 22/3/1982; SNI, Agência Rio de Janeiro, Informe $n^{\circ}$ 182/116/ARJ/82, 28/12/1982; SNI, Agência São Paulo, Informe nº 0014/16/ASP/83, 14/11/1983 508 Para o atendado ao Riocentro e suas consequências políticas, SCHWARCZ, Lilia M. e STARLING, Heloisa M. Brasil: uma biografia. São Paulo: Companhia das Letras, 2015, p. 482

509 SNI, Agência Central, Encaminhamento $n^{\circ}$ 41/17/AC/80, 17/11/1980; Ministério das Comunicações, Divisão de Segurança e Informações, Informação nº 0222/81/DSI/MC, 29/4/1981

${ }^{510}$ Ministério do Exército, Gabinete do Ministro, CIE, Informação no 295-S/103.1-CIE, 26/5/1981

511 SNI, Agência Central, Informação nº 172/19/AC/80, 17/6/1980
} 
sucesso no tricampeonato na Copa do Mundo de 1970] e de apoio à obra de recuperação do País pós-1964"512.

Se sob holofotes o regime negociava a volta da democracia, nas sombras parecia estar disposto a aceitar, no máximo, como diria Odorico Paraguaçu, a democratura.

512 Ministério dos Transportes, Divisão de Segurança e Informações, Informe nº 030/SICI/DSI/MT,82, $10 / 5 / 1982$ 


\subsection{Capítulo 13 \\ Diabo morto, inferno vivo}

Sérgio Penafiel, um jornalista militante do PCB, encontra-se inesperadamente com sua mulher em um apartamento que serve como aparelho do Partido. Cercado pela polícia, o casal vive uma explosão de estresse na qual discute o casamento e a militância política. Depois de mútuas acusações, o homem pergunta se ele é um "monstro". A resposta é dura:

\footnotetext{
Não, um intelectual apenas. Capaz de gestos maiores, mas também das maiores fraquezas. Frequentemente indeciso entre morrer por uma nobre causa e viver pelos pequeninos e muitos prazeres de uma existência acomodada. Enfim, um ser admirável e desprezível ao mesmo tempo. ${ }^{513}$
}

Escrita por Dias Gomes em 1969, “Amor em Campo Minado” era uma tentativa, nos mais sombrios tempos pós AI-5, de refletir sobre o papel da esquerda, em especial o do intelectual militante -ou seja, sobre a própria condição do dramaturgo. Censurada à época, além de criticada pela oposição, a peça estreou em 12 de julho de 1984, em Recife. Era o ano de despedida da ditadura, e a trama parecia mais atual do que nunca. A esquerda estava enfraquecida e se sentia excluída do processo de transição para a democracia. O último grande movimento de unificação da oposição, as Diretas Já, havia sido derrotado em abril, quando a emenda propondo que a sociedade pudesse votar para presidente da República fora rejeitada pelo Congresso. O "sonho da grande frente de oposição" (que no final da década de 1970 unira liberais a diferentes facções da esquerda em torno de causas comuns como a Anistia e o fim da censura) vivia um processo de implosão desde o começo dos anos 1980. Na explicação do historiador Marcos Napolitano, isso aconteceu "quando a questão democrática encontrou a questão operária", a partir do surgimento da chamada "República de São Bernardo", que demonstrou a força de mobilização sindical nas indústrias metalúrgicas da região do $\mathrm{ABC}$, em São Paulo. “A entrada desse novo e vigoroso ator na luta pela democracia

\footnotetext{
513 O trecho, o resumo, a data e o local de estreia da peça "Amor em Campo Minado" estão em SACRAMENTO, Igor Pinto. Nos tempos de Dias Gomes - A Trajetória de um intelectual comunista nas tramas comunicacionais, doutorado na UFRJ, 2012, p. 394-399
} 
assustou os liberais e autoritários, que aceleraram as articulações para uma saída negociada do regime" 514 .

O marco dessa ruptura fora a maior paralisação de trabalhadores já vista no Brasil, em maio de 1978. Em quatro semanas, 100 mil trabalhadores de 55 empresas pararam. Assim ressurgia no vocabulário nacional a palavra "greve", até então esquecida, o que mudaria a história do País ${ }^{515}$. A partir do movimento dos operários e da consequente criação, em 1980, do Partido dos Trabalhadores, ambos protagonizados pelo metalúrgico Luiz Inácio Lula da Silva, que nunca militara no PCB, deu-se, no dizer de Napolitano, "uma das mais ruidosas dissidências à esquerda no contexto da transição"516. O velho Partidão, por outro lado, estava abatido com a crise do comunismo internacional.

Se a vida tinha sido dura para Sérgio Penafiel/Dias Gomes nos anos de chumbo, na "democratura" também não se mostrava fácil. Mas, ao menos, seus dramas podiam vir à tona, como comemorou o dramaturgo no "Jornal do Brasil":

Na época [que a peça foi escrita, em 1969], alguns achavam que eu tinha sido injusto com a intelectualidade de esquerda que, afinal de contas, não se corrompera e lutava com a bravura possível contra o regime militar. Outros discordavam da oportunidade de se exorcizar publicamente nossos erros e contradições. Hoje é possível is so. Uma parte da esquerda ainda pode receber mal a peça, mas há uma tendência à democracia. A peça reflete ainda um estado de perplexidade e uma ânsia de compreender o que aconteceu. Por que os nossos sonhos de justiça social, que pareciam tão solidamente enraizados numa realidade política que nos parecia real, desmoronaram em poucas horas ao sopro de ventos que talvez não dessem para derrubar nem mesmo um castelo de cartas? Partindo do pressupos to que erramos, onde erramos? E quais as origens dos erros? ? $^{517}$

O autor se aproximava do PMDB, mas não deixava de ser solidário ao PCB e, em 8 de agosto de 1984, conforme registrou o SNI, foi um dos 50 convidados da sessão

\footnotetext{
514 NAPOLITANO, Marcos. 1964 - História do regime militar brasileiro. São Paulo: Contexto, 2014, p. 248-249; 276-277

515 GASPARI, Elio. A ditadura acabada. Rio de Janeiro: Intrínseca, 2016, p. 45; 56

516 NAPOLITANO, Marcos. 1964 - His tória do regime militar brasileiro. São Paulo: Contexto, 2014, p. $278-279$

517 Dias Gomes / Perfil sem piedade de certa esquerda. Jornal do Brasil, 14/5/1984 [matéria não assinada]
} 
especial de lançamento de um filme sobre a história do Partido, que seria usado na campanha para legalizá- $\mathrm{l}^{518}$, o que aconteceria no ano seguinte (Dias Gomes nunca demonstraria simpatia pelo PT, ao contrário; para ele, o novo partido "não era inovador" e cometia "todos os erros que o PCB cometeu na sua infância" 519 ).

Enquanto tentava exorcizar seus fantasmas da política, lidava com o luto pela morte de Janete Clair, em 16 de novembro de 1983, vítima de câncer. Desde as primeiras peças de rádio que havia ditado para a então namorada datilografar, passando pela intensa troca de ideias nas telenovelas, era a primeira vez, depois de 30 anos, que ele se via sozinho diante da máquina de escrever.

Pouco antes da estreia de "Amor em Campo Minado", em julho de 1984, havia vendido os direitos de "O Bem-Amado" para a Globo, transferindo para outros roteiristas a criação dos episódios ${ }^{520}$. A série sairia do ar definitivamente no dia 9 de novembro daquele ano de 1984, apesar do apelo de intelectuais. Um abaixo-assinado foi entregue à Globo com a assinatura de Jorge Amado, Carlos Drummond de Andrade e outros, de políticos e do próprio Dias Gomes por uma nova temporada. Reportagem do "Jornal do Brasil" registrou que, na avaliação da Globo, o programa, depois de quatro anos de duração, não fazia sentido naquele momento político, que "não teria a mesma graça fazer sátira em torno da conciliação" ${ }^{521}$.

Em 12 de novembro, três dias após a exibição do último episódio de "O BemAmado", Dias esteve com o peemedebista Tancredo Neves, o candidato da conciliação à Presidência da República. O político chegou ao Teatro Casa Grande, no Rio, abraçado ao ator Grande Otelo, para discutir o fim da censura com artistas e intelectuais. No palco, dividiu a mesa com Tom Jobim, Tônia Carrero, Dina Sfat, Rubem Fonseca, Dias Gomes, Nelson Pereira dos Santos, entre outros. Ao final do encontro, prometeu acabar com a censura política ${ }^{522}$. Assim, evidenciava que não haveria um extermínio amplo, geral e irrestrito do cerceamento à produção cultural. Mas já era algo a se comemorar.

\footnotetext{
518 SNI, Agência Rio de Janeiro, Informe no 377/SS31/ARJ/SE-3/84, 8/8/1984

${ }^{519}$ FALCONE, Maria Carolina. Dias Gomes: Não haverá censura política com o presidente Tancredo Neves. Tribuna da Imprensa, 8/11/1984, p. 12

520 Troca de autores. Veja, ed. 826, 4/7/1984, p. 74 [matéria não assinada]

${ }^{521}$ Reportagem do "Jornal do Brasil" de 9/11/1984 citada por SACRAMENTO, Igor Pinto. Nos tempos

de Dias Gomes - A Trajetória de um intelectual comunista nas tramas comunicacionais, doutorado na UFRJ, 2012, p. 387

522 No Rio, Tancredo ouve artistas e intelectuais. Folha de S.Paulo, 7/11/1984, p. 44 [matéria não assinada]
} 
O ano de 1984, apesar das brisas democráticas, registrara um gravíssimo episódio de censura política. Uma semana antes da votação das Diretas pelo Congresso, que aconteceu em 25 de abril, o presidente Figueiredo assinou um decreto proibindo rádios e TVs de transmitirem a sessão. Vieram outras medidas autoritárias, como liberação para busca e apreensão em domicílios e veto a reuniões e associações. No País da piada pronta, houve, no mesmo dia da assinatura do soturno decreto, um blecaute que deixou 12 milhões de pessoas de quatro Estados em completa escuridão ${ }^{523}$.

A TV Gazeta de São Paulo decidiu descumprir a ordem, transmitindo a votação das Diretas, e teve seus transmissores lacrados, ficando fora do ar por um dia ${ }^{524}$.

A manchete da "Tribuna da Imprensa" para a cobertura do encontro entre Tancredo e os artistas foi comemorativa ('Dias Gomes: 'Não haverá censura política com o presidente Tancredo Neves" 525 ). O autor disse que "o postulado básico do documento entregue ao candidato era a extinção da censura política":

A principal reivindicação é relativa à censura, que, segundo Dias Gomes, é o maior entrave ao desenvolvimento da cultura brasileira. Lembra que não se pode ter uma cultura sadia sem ter uma cultura livre. E noss a censura, como qualquer censura, é retrógrada, sendo a nossa mais retrógrada do que as outras, por seu mecanismo e por sua inspiração autoritária. "O postulado básico é, não a abolição da censura, o que seria des ejável, mas uma utopia, pelo menos que a censura não seja política, mas que seja apenas uma censura etária, que discrimina peças, obras culturais por idade, nunca uma censura política nem uma censura moral."

Sublinha Dias Gomes que não pode admitir uma censura política. E a censura moral é uma coisa instável, uma vez que os valores morais mudam de um dia para o outro. "A sociedade evolui, os costumes se alteram, sendo muito difícil estabelecer regras. A grande censura deve ser feita, mesmo, pela sociedade, porque aquilo que a sociedade recusa é impraticável principalmente num regime capitalista, onde tudo tem que ser rentável. Encena-se uma peça. Se a sociedade a recusa por achar que ela atenta contra os seus padrões morais, essa peça tem que sair de cartaz. A própria sociedade vai recusando e fazendo a sua seleção. A sociedade é que faz a censura. Essa

\footnotetext{
${ }^{523}$ Emergência de novo em Brasília; Blecaute total atinge quatro Estados. Folha de S.Paulo, 19/4/1984, p. 1 [chamada não assinada]

524 PRIOLLI, Gabriel. A emergência e a censura na televisão. Folha de S.Paulo, 27/4/1984, p. 44

525 FALCONE, Maria Carolina. Dias Gomes: Não haverá censura política com o presidente Tancredo Neves. Tribuna da Imprensa, 8/11/1984, p. 12
} 
é a única censura aceitável. Não sei se o dr. Tancredo Neves concordará com tudo isso, mas pelo menos no Teatro Casa Grande ele declarou que em seu governo aboliria a censura política." 526

Dias Gomes percebia que a volta da democracia se dava sob forças conservadoras. "Tancredo não é nenhum revolucionário. Nós sabemos que ele não vai mudar nada e que é um homem conservador, ligado ao próprio sistema. Mas sabemos que é digno, que tem uma cara honesta, o que o outro candidato [Paulo Maluf, do PDS, partido oficialmente ligado aos militares] não tem.”

Tancredo Neves foi eleito pelo voto indireto do Congresso em 15 de janeiro de 1985. Era o fim de 20 anos de ditadura militar no País, que entrou em clima de festa. No dia seguinte, Dias Gomes voltou a falar sobre o fim da censura ao "Jornal do Brasil", classificando como "anseio utópico" a sua abolição total. "Sabemos que Tancredo Neves se comprometeu a acabar com a censura de motivação política. É um grande passo. Por outro lado, o futuro presidente deixou bem claro que a censura deve continuar a preservar a moral e os bons costumes", disse Dias. Em seguida, o autor retomou a tese liberal de deixar para o mercado a função de regular o que pode e o que não pode:

A única censura verdadeira é a da sociedade, do povo. Se o povo não vai ver uma peça, ela tem que sair de cartaz. E ninguém se sustenta profissionalmente sem dinheiro [...] Isto não quer dizer que sejamos adeptos da irresponsabilidade. Afinal existe um Código Penal para punir os abusos.E em países desenvolvidos como os Estados Unidos, França e Inglaterra não existe censura prévia [...] Hoje já temos até sexo explícito na televisão. Há alguns anos, seria inadmissível a apresentação de certas cenas de filmes brasileiros, como os que foram exibidos na TV Globo. A censura moral é sempre duvidosa. ${ }^{527}$

Em 15 de fevereiro, um mês antes da data da posse de Tancredo, a "Folha de S.Paulo" publicou a reportagem "Muda o governo, chega a nova censura" ${ }^{28}$, sobre as expectativas da elaboração de uma nova lei. O presidente da Abert (Associação

\footnotetext{
526 Ibidem

527 Ibidem

528 COURI, Norma. Muda o governo, chega a nova censura. Folha de S.Paulo, 15/2/1985, p. 31
} 
Brasileira de Emissoras de Rádio e TV), Joaquim Mendonça, disse o que esperava da Nova República citando música de Caetano Veloso: "É proibido proibir”. A pesquisadora Beatriz Kushnir aponta o nó dessa frase: A partir dela, "preconiza-se que uma interdição permite sempre uma leitura de que seria mal recebida e indesejada [...] Essa ideia não é uma afirmação inteiramente verdadeira, pois muitos setores da sociedade civil a desejam e pedem" ${ }^{\prime 29}$. Justamente por isso a censura não acaba totalmente em períodos democráticos.

A própria "Folha" demonstraria, poucos dias depois, em 24 de fevereiro, uma divisão da população sobre o tema. Pesquisa do Datafolha perguntou a mil pessoas na cidade de São Paulo o que pensavam sobre a censura prévia à televisão: 47\% se disseram contrários a qualquer tipo de censura prévia e 41,4\% acreditavam que a programação deveria ser controlada (11,2\% não tinham opinião formada). $\mathrm{O}$ levantamento mostrava que a maior preocupação era com a moral e os bons costumes, que deveriam ser o foco do controle para $56,5 \%$ dos entrevistados, seguido pela violência, para $38 \%$. A política era o temor de apenas $4 \%$. De acordo com a reportagem, as telenovelas eram naquele momento o principal alvo da Censura, apesar de apenas $11 \%$ dos entrevistados considerarem que deveria ser assim. O autor Silvio de Abreu relatava que suas duas novelas mais recentes, "Guerra dos Sexos" e "Vereda Tropical", exibidas entre 1983 e 1985, haviam sofrido, em média, cinco cortes por capítulo. Diretor de criação da TV Globo, Daniel Filho foi contundente: "A verdade é que agora, depois de 15 anos, a Censura não tem coerência e acho que uma das razões dessa falta de critérios é que a censura exercida por dona Solange Hernandez [diretora da Divisão de Censura de Diversões Públicas, a DCDP] é uma forma de pressão política”. Diretor substituto da DCDP, José Guedes afirmou que os critérios "são aqueles que dizem respeito à violência, à moral e costumes, à tensão, suspense e ferocidade, às vulgaridades e baixezas na linguagem, à família, à religião, ao civismo e ao sentido de dever". Para ele, os problemas maiores da Divisão de Censura não estavam relacionados a critérios, e sim eram "de ordem material" 530 . A demanda por mais estrutura seria

\footnotetext{
${ }^{529}$ KUSHNIR, Beatriz. Cães de Guarda - Jornalistas e censores do AI-5 à Constituição de 1988. São Paulo: Boitempo, 2004, p. 76

530 Para as informações da reportagem sobre a pesquisa, Censura prévia à TV divide população. Folha de S.Paulo, 24/2/1985, p. 49 [matéria não assinada].
} 
atendida, e a Nova República realizaria, em seu primeiro ano, um concurso para a contratação de novos censores ${ }^{531}$.

Mas o discurso de que a censura teria fim seguiu firme, inclusive após o trauma da morte de Tancredo, cujo cargo foi ocupado pelo seu vice, José Sarney, que fora presidente da Arena e do PDS (Partido Democrático Social), ambos de sustentação dos militares. Quando formou a chapa da Aliança Democrática com Tancredo, Sarney já era líder da Frente Liberal, dissidência do PDS, que se tornaria o PFL.

O presidente manteve para o Ministério da Justiça o nome escolhido por Tancredo, o advogado e deputado federal pernambucano Fernando Lyra. No dia 14 de março, véspera da posse de Sarney, o futuro ministro declarou: "A partir de amanhã a censura política está extinta no País" ${ }^{\prime 532}$. Poucos dias depois, criou a Comissão dos Perseguidos da Censura, reunida pela primeira vez em 29 de março, apenas duas semanas após a posse do novo governo. Do grupo inicial faziam parte o músico Chico Buarque, o escritor Antônio Houaiss, a cineasta Ana Carolina Soares e o cartunista Ziraldo. Dias Gomes logo se juntaria a eles. Ao anunciar a comissão, que iria elaborar uma proposta de legislação censória, Lyra assegurou: 'Não haverá censura política, e

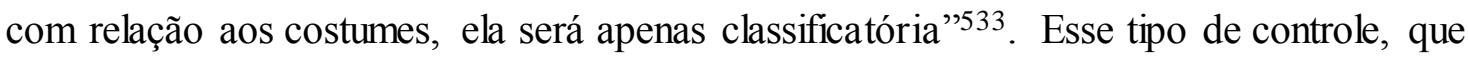
determina faixas etárias para as obras, havia surgido na legislação em 1968, na lei 5.536, a mesma que criara o Conselho Superior de Censura, assinada por Costa e Silva.

Em 26 de março, Solange Hernandez, a famigerada Solange Tesourinha, foi substituída por Coriolano de Loyola Cabral Fagundes na chefia da DCDP. Censor desde 1961, ele seria um nome mais "liberal", apesar de ter escrito em 1974 o livro que servia como um manual informal da Censura e de ter trabalhado como censor do governo dentro de Redações de jornais em 1973. Teria sido nomeado para desmontar a estrutura da Censura e extinguir a DCDP ${ }^{534}$. O clima era de celebração, conforme o título da "Folha": "Censura pendura tesoura e será só classificatória"535. Matinas Suzuki Jr.,

\footnotetext{
${ }^{531}$ KUSHNIR, Beatriz. Cães de Guarda - Jornalistas e censores do AI-5 à Constituição de 1988. São Paulo: Boitempo, 2004, p. 184

532 Censura política acaba amanhã, declara Lyra. Folha de S.Paulo, 14/3/1985, p. 6 [matéria não assinada]

533 Censurados debaterão os rumos da censura. Folha de S.Paulo, 22/3/1985, p. 50 [matéria não assinada]

${ }^{534}$ Para a data em que Fagundes entrou no cargo e a informação sobre sua atuação como censor em

Redações de jornais, KUSHNIR, Beatriz. Cães de Guarda - Jornalistas e censores do AI-5 à

Constituição de 1988. São Paulo: Boitempo, 2004, p. 79

535 Censura pendura tesoura e será só classificatória. Folha de S.Paulo, 26/3/1985, p. 36 [matéria não as sinada]
} 
contudo, em sua coluna da "Folha", percebeu a armadilha do discurso de uma "nova censura":

[...] Difícil, porém, é compreender os mecanismos que levaram os silenciados de ontem a aceitar a lógica difusa da articulação dos censorinos de hoje, ainda que para eles seja desconfortávelo capuz de carrasco.

Uma das confusões ideológicas que os intelectuais e artistas que aceitaram participar da nova interdição estão espalhando é a de que "abrandar" significa o mesmo que "diminuir" a censura. Nesta barafunda filológica, vai embutida a noção extremamente autoritária de que a censura moral é mais aceitável do que a censura ostensivamente política-como se a proibição de obras consideradas "obscenas" fosse um ato de violência impermeável aos fuzis do Estado [grifo nosso]. Trata-se de uma perniciosa visão do fato cultural [...] -até porque a censura diretamente política é conjuntural; muda-se o senhore ela transforma-se ou some. Já a crítica moral é inimiga de qualquer regime [...]

Mata-se o diabo, mas deixa-se o inferno vivo. Combate-se a censura política, mas naufraga-se no interdito moral. Até o paliativo da censura classificatória é questionávelem seu pseudo-didatismo, pois quem são estes senhores para etiquetar os desejos e os tormentos do imaginário de uma adolescente de 16 anos, hoje? 536

Sim, o diabo podia até estar morto, ou pelo menos agonizando, mas o inferno estava bem vivo. Enquanto a "Nova República" aparecia em manchetes de jornais diariamente, o SNI seguia tão ativo em 1985 que produziu oito documentos sobre o subversivo Dias Gomes. Foi uma média maior do que a dos anos de chumbo, cujo recorde havia sido cinco, em 1972.

Um dos documentos de 1985 é exemplar da esquizofrenia do período. Em 16 de agosto, a Divisão de Segurança e Informações do Ministério da Justiça encaminhou à Agência Central do SNI um informe, com o carimbo "reservado", anexando o despacho do secretário-geral da própria pasta, José Paulo Cavalcanti Filho, sobre as conclusões da comissão reunida para propor uma nova legis lação para a censura. $\mathrm{O}$ oficio indica que o despacho havia sido publicado no Diário Oficial da União no dia 13 de agosto, justamente para tornar públicas as propostas e solicitar que sugestões de qualquer

536 SUZUKI JR., Matinas. De censurado a censor. Folha de S.Paulo, 11/4/1985, p. 2 
interessado fossem encaminhadas ao ministério. Em outras palavras, era uma vigilância entre departamentos vizinhos. E para reportar algo que, além de oficial, estava em diversos jornais. A máquina montada durante 20 anos não iria se desmontar da noite para o dia. E provavelmente nunca seria desmontada, mas camaleonicamente transformada, na expressão de Gaspari ${ }^{537}$. A divisão de informações do ministério da Justiça que "dedurou" o trabalho da própria pasta sobre a censura ao SNI fazia parte de uma comunidade de informações que no governo Sarney contava com 248 órgãos ${ }^{538}$. A Nova República recebeu o SNI com 2.300 funcionários ${ }^{539}$. A Censura também manteve estrutura considerável no ano de 1985, com cerca de 200 técnicos, todos funcionários públicos concursados. A resistência desses grupos para manter seus empregos deve ser colocada na equação dos limites para a transição democrática ${ }^{540}$.

O inferno tinha seus adeptos.

537 GASPARI, Elio. Alice e o camaleão. In: GASPARI, Elio; Hollanda, Heloísa Buarque de; Ventura, Zuenir. 70/80: Cultura em Trânsito. Rio de Janeiro: Aeroplano Editora, 2000, p. 12, apud. KUSHNIR, Beatriz. Cães de Guarda - Jornalistas e censores do AI-5 à Constituição de 1988. São Paulo: Boitempo, 2004, p. 138

538 VALENTE, Rubens. Governo espionou críticos mesmo após fim da ditadura. Folha de S.Paulo, 31/5/2010, p. A4

539 GASPARI, Elio. A ditadura acabada. Rio de Janeiro: Intrínseca, 2016, p. 77

${ }^{540}$ Para o número de censores e a resistência para manter os cargos, KUSHNIR, Beatriz. Cães de Guarda - Jornalistas e censores do AI-5 à Constituição de 1988. São Paulo: Boitempo, 2004, p. 206-207. 


\subsection{Capítulo 14}

\section{A Nova República e o "sic" do SNI}

Boni almoçou com o presidente Sarney, e o vice, Marco Maciel, em Brasília, logo no início do novo governo. Conversaram sobre a escolha de Fernando Lyra para o Ministério da Justiça, e o presidente perguntou ao executivo o que seria importante fazer em relação à televisão: "O senhor poderia assinar um decreto acabando com a censura, não só do ponto de vista ideológico, mas burocrático. Se fizesse isso, passaria para a história do seu governo". Sarney the respondeu que Maciel iria tratar desse tema.

Na Globo, um dos assuntos prioritários para Boni era definir a próxima novela das oito, que substituiria "Corpo a Corpo", de Gilberto Braga, a partir de junho. Havia o desejo de ter Dias Gomes de volta ao horário, o que estava fora dos planos do autor, cansado da rotina pesada e da repetição de linguagem nas telenovelas. Em março daquele 1985, passou a comandar a Casa de Criação Janete Clair. O projeto, sugestão de seu filho Alfredo, conciliava uma homenagem à mulher com a sua tentativa de encontrar um rumo para a carreira televisiva. O filho pensara em algo independente, um centro cultural, com espaço também para música e poesia. Mas Dias não quis se arriscar, se achava péssimo administrador de negócios, e sugeriu que a Globo incorporasse uma versão adaptada da ideia como forma de buscar e treinar roteiristas. Veio a calhar para a emissora, que vivia uma crise criativa na teledramaturgia, com os poucos autores já exaustos após anos de trabalho ininterrupto, e com o desafio de propor algo para o novo momento do País ${ }^{541}$.

Dias se comprometeu a elaborar argumentos para as futuras novelas, que seriam desenvolvidos pelos talentos descobertos, sob a sua supervisão. Um sobrado no Jardim Botânico, vizinha à sede da TV, foi alugado, e o dramaturgo montou sua sala, com um quadro de um grande retrato de Janete atrás de sua mesa. Na sala ao lado, ficava Ferreira Gullar, seu assistente nesse espécie de "departamento externo" da Globo. Euclides Marinho, Doc Comparato, Joaquim Assis e Marília Garcia também formavam a primeira equipe da Casa de Criação.

\footnotetext{
${ }^{541}$ Entrevista de Alfredo Dias Gomes, filho do dramaturgo, à autora em sua residência, no Rio, em 11/5/2011.
} 
A expectativa era a de que a próxima novela das oito fosse concebida no sobrado administrado por Dias. E o cronograma estava gravemente atrasado. Surgiu então a ideia, apresentada pelo então novato autor Aguinaldo Silva, de colocar a Nova República em cena. A novela, "O Mais Querido", faria uma metáfora do País, com um clube pessimamente administrado há 20 anos pelo mesmo grupo, que agora finalmente saía do poder após vitória da oposição nas eleições. O que Aguinaldo não devia imaginar era que sua celebração da Nova República fora registrada pelos diabos sobreviventes da Velha República, os agentes de vigilância. Em 15 de abril, a Nova República completava um mês quando o Centro de Informações do Departamento da Polícia Federal encaminhou um informe ao SNI e às inteligências do Exército (CIE), Marinha (Cenimar) e Aeronáutica (Cisa) cujo assunto era: "Rede Globo de Televisão A novela 'O Mais Querido"'542. O documento mencionava a Casa de Criação Janete Clair (listando cada membro e sua função no departamento), que, "segundo vem sendo divulgado pela imprensa" (sem citar ou anexar as reportagens), foi criada para "suprir a deficiência" no departamento de teledramaturgia da Globo, "que tem tido dificuldade para produzir novelas e similares devido à exaustão criativa dos escritores".

O relatório pinça declarações de Aguinaldo a jornais, às quais atribui um "sic" que soa irônico: '[A temática de fundo da novela 'O Mais Querido' é a Nova República], esse momento de transição que todos nós, brasileiros, estamos vivendo (sic)". Também o "sic" provocativo surge quando a censura entra em pauta nas aspas do autor: “"A estória é uma metáfora bem clara, o público reconhecerá os fatos. Essa é a primeira novela a ser escrita na Nova República e eu não perderia essa chance crítica que me foi negada em tantos anos de censura', diz Aguinaldo Silva (sic)". A inserção do "sic" pelo SNI não tem razão clara. Pode, contudo, ser entendida como um discordância à fala do autor. Ou seja, a Nova República não seria um momento de transição, e a censura não havia negado a Aguinaldo Silva a chance de ser crítico.

De qualquer forma, o SNI não precisaria mais se preocupar com a novela sobre a Nova República. Ela não emplacou na Globo. A ideia para a trama das oito surgiu em um almoço da cúpula da emissora. O escritor Otto Lara Resende, que atuava como uma espécie de "assessor de luxo" de Roberto Marinho, levantou a bola para que se aproveitasse a onda democrática com a qual o telespectador estava tão sintonizado.

\footnotetext{
542 Ministério da Justiça, Departamento de Polícia Federal, Centro de Informações, Informe $\mathrm{n}^{\mathrm{o}}$ 403/01/V/85-CI/DPF, $15 / 4 / 1985$
} 
"Vamos inventar um troço qualquer, pega uma novela que foi censurada... Não tem algum texto proibido aî?" Daniel Filho embarcou: "Por que a gente não tenta de novo o 'Roque Santeiro?". Os outros presentes, Boni e Armando Nogueira, acharam uma ótima saída. Afinal, a censura estava acabada, pensaram. E nada melhor do que levar ao ar uma novela censurada para comemorar - e comprovar- o fim da censura.

Boni telefonou para Dias Gomes e perguntou se seria preciso refazer o texto. $\mathrm{O}$ dramaturgo respondeu que faria os personagens um pouco mais "nervosos, mais excitados". E o elenco? Dez anos depois, teria que ser outro? O autor achava que não, e ficou combinado que os atores de 1975 seriam consultados para saber se queriam ou não voltar ao pape ${ }^{543}$. Era preciso correr. Se a primeira versão havia iniciado sua produção quase seis meses antes da data da estreia, esta, a dois meses do lançamento, não tinha diretor, elenco nem autor, porque Dias Gomes, que havia escrito os 51 capítulos iniciais da versão de 1975, deixou claro que não iria assumir o batente diário.

A notícia saiu na "Folha de S.Paulo" em 29 de abril, com o título "Roque Santeiro', dez anos depois" ${ }^{\prime 544}$. No dia seguinte, chegou a Coriolano de Loyola Cabral Fagundes, o diretor da Divisão de Censura de Diversões Públicas, a sinopse da novela. Era a mesma de 1975, com irrisórias atualizações, e a mudança do tempo da história. Enquanto a primeira se passava em 1960 (para evitar problemas com os militares), com Roque tendo "sido morto" em 1943, a segunda era localizada no presente, em 1985, e desta vez, os 17 anos para trás, caíam em uma época propícia para o nascimento de falsos heróis, o ano da assinatura do AI-5, 1968. Abaixo, alguns trechos:

\section{O MITO}

Faz já 17 anos que Navalhada e seu bando [...] surgiram na vila de Asa Branca, ocupando a Prefeitura, exigindo dois carros e uma grande quantia em dinheiro para deixar a população em paz. Os moradores, miseráveis, fizeram um apelo a Sinhozinho Malta, único homem rico do lugar. O fazendeiro cedeu os carros, mas não possuía todo aquele dinheiro em sua fazenda, apenas metade. Era preciso parlamentar com o bandido, conseguir um prazo maior. Foi quando apareceu Roque Santeiro, um jovem tímido, que fora sacristão e tinha esse apelido devido à sua habilidade em modelar santos em barro ou madeira. Roque se ofereceu para levar o dinheiro ao facínora [...] Partiu e voltou horas depois com a resposta de Navalhada:

\footnotetext{
543 Para o almoço e as decisões sobre "Roque Santeiro", entrevista de Boni à autora.

544 "Roque Santeiro", dez anos depois. Folha de S.Paulo, 29/4/1985, p. 23 [matéria não assinada]
} 
[...] não concordara em dar prazo maior que duas horas para conseguirem o restante. Findo esse tempo, saquearia a cidade. Seria impossível conseguiro dinheiro em tão pouco tempo, o fazendeiro tratou de fugir, no que foi acompanhado por toda a população (cerca de 500 habitantes), à exceção de Roque Santeiro, que decidiu ficar [...] Roque se impôs a missão de defender a igreja, na qual havia algumas relíquias valiosas [...] Quando o bando de Navalhada invadiu a cidade, encontrou-o diante do templo [...] Santeiro caiu morto, crivado de balas. De seu corpo foram encontrados apenas restos sangrentos, atirados no rio, a um quilômetro dali. Mas no momento em que os bandidos penetravam a igreja e levavam o ostensório de ouro, caiu sobre a cidade uma tremenda tempestade e o sino começou a badalar misteriosamente [...] Os bandidos deram no pé. Quando a população voltou, no dia seguinte, tomou conhecimento do milagre e do sacrifício de Roque Santeiro. Tempos depois, uma criança teve uma visão. Estava brincando na lama do rio, próximo ao local onde o corpo mutilado de Roque fora encontrado, quando este the pareceu, besuntou suas pernas de lama e sumiu numa nuvem. A criança sofria estranhas feridas na perna e curou-se. $O$ novo milagre fez com que daí em diante a lama do riacho fosse considerada milagrosa. E os romeiros começaram a chegar [...]

\section{A EXPLORAÇÃO DO MITO}

Com a afluência de romeiros, com a divulgação do acontecido, a vila passou a ser alvo da curiosidade geral [...] Um produtor cinematográfico decidiu filmar a estória fabulosa de Roque Santeiro. Nesse ponto,já a vila crescera e adquirira foros de cidade. Dezessete anos se haviam passado [...] Uma pequena indústria se desenvolvera à sombra do mito. Imagens, medalhinhas [...] As romarias e a afluência de turistas haviam possibilitado a abertura de hotéis e restaurantes [e a boate Sexus estava prestes a ser inaugurada]. Viúva Porcina era uma das pessoas mais influentes da cidade, elegendo prefeitos e deputados pelo prestígio que lhe dava a sua condição de ex-companheira do herói-mártir. O atual prefeito mesmo, Seu Flô, fora eleito por ela [...] O vigário era talvez a única pessoa na cidade a recusar-se a dar crédito aos propalados "milagres" [...] No entanto, era obrigado a tolerar o culto $[\ldots]$

\section{ESTRUTURA DA NOVELA}

[...] As coisas estão nesse pé, quando um forasteiro chega à cidade. [Porcina, Sinhozinho e o padre Hipólito, ao encontrarem o rapaz] descobrem a verdade: Roque não somente não morrera, como nem sequer enfrentara os 
malfeitores [... Inventara toda a história e] Fugira com o dinheiro e o ostensório de ouro. Porque os bandidos não tinham atacado. Ele simulara o ataque, sozinho que ficara na vila [atirando pedaços de um animal morto ao Rio]. No primeiro encontro que tivera com Navalhada, convencera o facínora com a sua lábia a desistir da empreitada. Voltava agora pensando em pedir perdão ao padre e redimir-se, fazendo alguma coisa em prol daquela gente.

[...] A circunstância exige a revelação de outra farsa: Porcina e Roque jamais haviam se encontrado antes [...] Malta [seu amante] inventara toda aquela estória [...] A volta de Roque cria uma situação insolúvel [...] A cidade, que cresceu à sombra de um mito, estaria condenada à morte, se viesse a conhecimento público que seu mártir era um criminoso [...] Além de ser uma vergonha para todos, importaria em incalculáveis prejuízos materiais [...] Roque é uma ameaça à cidade e a única maneira de salvá-la é eliminá10.545

O resumo seguiu para a Divisão de Censura acompanhado de oficio assinado por Daniel Filho, diretor da Central Globo de Produção, pedindo a liberação da novela para as 20h. Na mensagem a Coriolano, ele relembra resumidamente as idas e vindas com a DCDP até que se chegasse ao cancelamento da novela em 1975.

Por motivos que, data vênia, entendemos ocioso enumerar agora, nem o então diretor dessa Divisão, Dr. Rogério Nunes, nem o diretor-geral do Departamento de Polícia Federal, Cel. Moacyr Coelho, deram acolhida à solicitação da TV Globo [...]

Amparados na certeza de que não mais subsistemos motivos que deram ensejo àquela decisão censória de 1975, uma vez que o Governo da Nova República, pela voz autorizada do Exmo. Sr. Ministro da Justiça, Dr. Fernando Lyra, tornou público que critérios democráticos e atualizados passariam a ser aplicados no exame classificatório dos espetáculos e diversões públicas, solicitamos que V. Sa. se digne mandar proceder a revisão de censura da telenovela "Roque Santeiro", para decidir da possibilidade para exibição às $20 \mathrm{~h} .546$

545 Trecho da sinopse anexada ao processo de "Roque Santeiro" na Divisão de Censura de Diversões Públicas.

${ }^{546}$ Carta anexada ao processo de "Roque Santeiro" na Divisão de Censura de Diversões Públicas com carimbo $\mathrm{n}^{\circ} 3.771$ 
Em 14 de maio, a "Última Hora" anunciou, com o seguinte título, a escolha da novela para o horário nobre da Globo: "Dias Gomes - Um novo tempo com 'Roque Santeiro' - Depois de dez anos ele retoma o texto de uma novela absurdamente proibida"547. A reportagem entrevistava Paulo Gracindo, que, após se despedir do prefeito Odorico, de "O Bem-Amado", seria o Padre Hipólito na nova obra (na versão de 1975, o padre se chamava Honório e era interpretado por Milton Gonçalves): “É muito gostoso trabalhar neste momento em 'Roque Santeiro', uma obra perseguida pela Censura na TV, não sei por que motivo. Mas ela está aí, vai entrar no ar em junho e dá pra gente ver o futuro com esperança, embora um pouco desconfiado. Afinal, pobre quando vê muita esmola...” Para Dias, “o fato de poder apresentar em 1985 uma novela proibida na Velha República significa um bom sinal". "A Nova República está dando o ar da graça", disse o autor.

Sim, era bom mesmo o santo desconfiar do milagre, porque quem deu o ar da graça, no dia seguinte à reportagem, foi a Censura. Em 15 de maio, Daniel Filho recebeu a resposta de Coriolano Fagundes sobre o pedido de liberação da novela para as 20h. Era um "sim", mas bem longe do "é proibido proibir...". A autorização estava condicionada ao exame de videoteipe dos dez primeiros capítulos, como em 1975. E mais:

Pedimos especial atenção da emissora para as abordagens de adultério, prostituição, insatis fação sexual, livre relação amorosa e religião, principalmente mensagens favoráveis ao movimento dissidente da Igreja $\underline{\text { Católica, que deverão receber tratamento adequado ao horário e veículo }}$ [grifo nosso].

Lembramos que sempre que a obra sofra alterações, faz-se necessána a remessa dos adendos a este Órgão. ${ }^{548}$

Coriolano se referia à Teologia da Libertação, movimento da Igreja Católica ligado à esquerda. A nova versão da novela de fato teria um padre dessa linha, Albano (Cláudio Cavalcanti), que iria se contrapor ao tradicional Hipólito. Mas ele não estava previsto na sinopse que Coriolano leu, seria criado depois. A única vaga menção ao

\footnotetext{
547 d'ALMEIDA, Regina. Dias Gomes - Um novo tempo com "Roque Santeiro". Última Hora, 14/5/1985

548 Divisão de Censura de Diversões Públicas, ofício nº 795-SE/DCDP, 15/05/1985
} 
assunto aparecia na caracterização de Hipólito, na lista de personagens que acompanhava a sinopse. Eram sete palavras, em 24 páginas. Descrito como um "padre típico do interior, o padre-povo e paternal", ele, "apesar de seu dogmatismo, [de] sua oposição à corrente renovadora da Igreja, é profundamente simpático [grifo nosso]".

Quem apontou a questão ao chefe da DCDP foi uma das duas censoras designadas a produzirem pareceres sobre a sinopse, Maria das Graças Sampaio Pinhati, conforme trecho abaixo:

$\underline{\text { Possível ridicularizacão dos padrões religiosos, de moral e conduta }}$ através da ação extremada e retrógrada do padre local e das beatas portadoras -na maioria dos casos-de problemas de ordem sexual; possível inserção de mensagens favoráveis à Teologia da Libertacão -movimento dissidente da Igreja Católica, cuja linha de ação fundamenta-se no marxismo. A sinopse faz dis creta alusão ao fato. No caso específico, o contestador desta corrente será o padre Hipólito, um personagem simpático, porém desacreditado pelo público, face a sua imagem de religioso retrógrado, com ideias inteiramente superadas. A nosso ver, se este assunto for abordado de modo parcial, poderá causaruma série de protestos da Igreja Católica, em face ao delicado e grave problema que vem enfrentando [grifos originais]. ${ }^{549}$

O outro parecer, de Joana Silveira Passos, concentrou-se nas questões morais, inclusive com a "sugestão" para que o nome da boate da novela, Sexus, fosse alterado, por ser um "indicador ostensivo da verdadeira proposta de Matilde", sua proprietária. A chefe das duas pareceristas, Maria Aurineide Pinheiro, considerou irrelevante esse detalhe, mas não o da Teologia da Libertação. Coriolano concordou e oficiou a Globo.

Essa primeira ressalva à novela trazia uma importante interrogação. Se a censura política estava abolida na Nova República, segundo discursos e mais discursos, o que explicava o veto à Teologia da Libertação na novela? Essa restrição à corrente de esquerda da Igreja deveria, então, ser considerada uma censura moral, que seria mantida pelo novo governo? A fragilidade dessa tipificação de "censuras", a política e a moral, já começava nesse primeiro oficio, antes mesmo de a novela estrear. E os censores e seus critérios mambembes não perdiam por esperar com a entrada em cena do personagem que representava a Teologia da Libertação. Padre Albano (Cláudio

\footnotetext{
${ }^{549}$ Ministério da Justiça, Departamento de Polícia Federal, Divisão de Censura de Diversões Públicas, Parecer $n^{\circ} 1542 / 85,13 / 5 / 1985$
} 
Cavalcanti), além de defender os pobres contra os ricos, ainda teria um romance com a filha de Sinhozinho, dando um verdadeiro nó entre política e moral.

Enquanto os trâmites seguiam com a Censura, com o envio dos capítulos, era grande a correria da produção. Dos três protagonistas da versão de 1975, apenas Lima Duarte, o Sinhozinho, topou voltar ao papel. Betty Faria, a Viúva Porcina, disse que ficara nervosa à época da proibição, que não se lembrava mais do tom e não se sentia confortável em retomar a novela. Cuoco, que fizera Roque, também não teve interesse, estava em um período de afastamento do vídeo. No início de maio, José Wilker foi escalado para o papel. Dias Gomes, Boni e Daniel Filho queriam Regina Duarte como a Viúva Porcina, mas ela estava fora da emissora, tentando uma carreira de produtora independente, havia três anos. Após intensa negociação, o contrato foi fechado no dia 24 de maio, a apenas um mês da estreia, e ela começou a gravar no dia $28^{550}$.

Além de Lima Duarte, apenas João Carlos Barroso, Luiz Armando Queiroz e Ilva Niño seguiram da primeira para a segunda versão no mesmo papel. Ilva Niño, aliás, é a única que estava também no elenco de "O Berço do Herói”. Na peça, em 1965, aos 30 anos, faria o papel da prostituta Ninon (que coube a Lady Francisco em "Roque Santeiro" 1, e a Cláudia Raia, em "Roque Santeiro" 2, sua estreia na TV). Nas novelas, Niño interpretou, aos 40 e depois aos 50 anos, Mina, a empregada de Porcina (que ela chamava gritando "Minaaaaaaaaaa!"). Barroso foi Toninho Jiló e Queiroz, Tito. Outros poucos voltaram, mas com papeis menores, como Milton Gonçalves (do padre principal para um promotor que apareceu em poucos capítulos), Elisângela (de Tânia, filha de Sinhozinho, para Marilda, mulher do galã Roberto Matias, interpretado por Fábio Jr.).

A cidade cenográfica foi montada no mesmo local de 1975, em Guaratiba. Mas, enquanto na primeira a construção levara mais de quatro meses, nesta, o tempo foi recorde na história da emissora: 20 dias, com 180 profissionais escalados para a maratona $^{551}$. Até a estreia, a cada dia foram gravadas em média 40 cenas, e Regina

\footnotetext{
550 Para as recusas de Betty Faria e Francisco Cuoco, entrevista de Boni à autora; para o contrato com Regina Duarte: Regina Duarte volta hoje à Globo. Folha de S.Paulo, 28/5/1985, p. 27 [matéria não assinada].

551 Para a cidade cenográfica, Dicionário da TV Globo - vol. 1: Programas de Dramaturgia \&

Entretenimento. Rio de Janeiro: Jorge Zahar Editor, 2003, p. 144
} 
Duarte chegou a ter que tirar rápidas sonecas, entre uma e outra, em colchonete colocado debaixo das araras com o figurino no camarim. Os dez capítulos a serem apresentados para a Censura, um trabalho que normalmente levaria um mês, foram aprontados em 17 dias. Dinheiro não faltava: o orçamento previsto foi de $\operatorname{Cr} \$ 250$ milhões por capítulo, o que daria, com o gasto total da novela, para pagar perto de oito superproduções cinemato gráficas dos padrões brasileiros da época ${ }^{552}$. A direção foi entregue a Paulo Ubiratan. Por orientação de Dias, Daniel Filho e Boni, o ritmo da trama ficou mais acelerado do que em 1975. Boni pediu mais "pimenta", achava a versão antiga "extremamente comportada" 553 . Para que Asa Branca fosse uma síntese do País, o cenário fez uma colagem de diferentes características das regiões brasileiras, misturando traços da arquitetura colonial carioca, nordestina e do Sul. O mesmo se deu com os sotaque, com Sinhozinho falando como nordestino, o prefeito, Seu Flô (Ary Fontoura), com toques mineiros, o delegado Feijó (Maurício do Valle), em "gauchês", e a dona da boate (Ioná Magalhães) e suas “meninas" (Cláudia Raia e Ísis de Oliveira), na língua carioca ${ }^{554}$. Aguinaldo Silva foi o escolhido para atualizar os 51 capítulos já escritos por Dias para a primeira versão e, depois, elaborar, sob a supervisão do dramaturgo, o restante da novela, tendo como assistentes Marcílio Moraes e Joaquim Assis (o projeto da novela sobre a Nova República foi engavetado).

No dia 24 de junho, a data da estreia, a "Ilustrada", da "Folha", resumiu o clima criado em torno da novela.

Com dez anos de atraso, "Roque Santeiro" chega enfim à tela da Globo, sem cortes, na versão integral concebida por Dias Gomes. E, como já se pretendia em 1975, quando a novela foi pesadamente cortada pela Censura, revestida do caráter de superprodução, com o objetivo de mudar o perfil das novelas do horário das 8. A ideia é trazê-la de volta, de acordo com Dias Gomes, 62, foi da própria direção da emissora. Afinal, raciocinou a cúpula global, nada melhor do que a proibida "Roque", símbolo da repressão

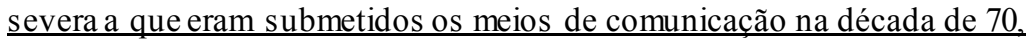

\footnotetext{
552 Para os prazos de gravação e o orçamento de cada capítulo: BARROS, Ambar de. "Roque Santeiro", um história de falsos milagres. Folha de S.Paulo, 24/6/1985, p. 24; para o descanso de Regina Duarte, entrevista da atriz Lucinha Lins à autora, em 4/9/2011.

553 Entrevista de Boni à autora.

554 Para o cenário e o sotaque da novela, Dicionário da TV Globo - vol. 1: Programas de Dramaturgia

\& Entretenimento. Rio de Janeiro: Jorge Zahar Editor, 2003, p. 144.
} 
para marcar o comeco de um novo tempo, o da "Nova República" [grifos nossos]. 555

A expectativa era a de que "Roque Santeiro" fosse realmente um marco do fim da Censura, pois "Corpo a Corpo", sua antecessora, sofrera cortes até o último capítulo, e a novela das sete, "Um Sonho a Mais", que terminaria em 2 de agosto, encarava uma repressão que seu autor, Lauro César Muniz, disse nunca ter visto nos 20 anos de ditadura militar -situação que a "Folha" denunciou em 22 de junho com a reportagem intitulada "A Censura continua como coautora das novelas" 556.

A novela símbolo da Nova República chegaria à tela sem cortes, após as ressalvas da Censura. Mas assim ela ficaria somente até o capítulo 11 . A partir do $12^{\circ} \mathrm{a}$ temida tesoura entraria em ação. O parecer sobre os dez primeiros episódios (cujos videoteipes foram enviados à Censura para a confirmação da classificação; o $11^{\circ}$ seria avaliado depois da estreia, também sem cortes) levanta questões morais, como os trajes "audaciosos" usados pelas dançarinas - mas que podem ser comparados, ponderam as três censoras que assinaram o relatório, com os das dançarinas de programas de auditório exibidos em horário livre. Há uma linguagem com "malícia acentuada", com expressões como "nos cornos dela" e "jejum total". As censoras alertam para uma música que não consta do script, cantada pelas dançarinas, e pede a apreciação da chefia, transcrevendo a letra: "Banana não tem caroço meu bem/ E não passa em qualquer pescoço neném/ Além de outras coisas mais/ Uma banana não satisfaz...” Os chefes deixam passar a banana, os trajes das dançarinas e outras malícias, em razão da "abordagem cômica"557.

E, então, na "versão integral", como comemorou a "Folha", a novela estreou. Mas a própria abertura da novela dava pistas de que tudo não passava de ilusão. Um congestionamento de carro, avistado de cima, mostra que os veículos estão confinados sobre uma vitória-régia, que nunca sairão dali (e a planta escolhida também é símbolo da ilusão: a lenda conta que uma índia esperava ser levada pela Lua mas morrera afogada ao se jogar na água por se confund ir com um reflexo do astro no rio; com

\footnotetext{
555 BARROS, Ambar de. "Roque Santeiro", um história de falsos milagres. Folha de S.Paulo, 24/6/1985, p. 24

556 A Censura continua como coautora das novelas. Folha de S.Paulo, 22/6/1985, p. 49

557 Ministério da Justiça, Departamento de Polícia Federal, Divisão de Censura de Diversões Públicas, Parecer no 3050/85, 21/6/1985; as três censoras que assinaram são Vilma Helena Sanan Domingos, Yêda Lúcia Netto Campos e Maria Angélica R. de Resende.
} 
remorso, a Lua decide transformar a índia em vitória-régia). Na música da abertura, “Santa Fé”, Moraes Moreira canta "Não sou nenhum São Tomé / no que eu não vejo eu ainda levo fé..." (A canção, aliás, também teve que passar pela Censura, como toda a trilha sonora, sendo que uma delas, "Indecente", tema da dona da boate, só conseguiu a liberação após recurso ao Conselho Superior de Censura ${ }^{558}$ ).

Foi um sucesso de cara. Reportagem da "Veja", em 17 de julho, registrou que nas três primeiras semanas a audiência foi de $72 \%$ na Grande Rio e $61 \%$ na Grande São Paulo, um feito inédito (para comparação, as duas anteriores não haviam ultrapassado, nesse período, 65\% na Grande Rio e 55\% na Grande SP). Dizia a revista que o mito, que de dez em dez anos tentava viver sua fantasia até o fim, agora finalmente chegava ao vídeo. E que já derrubava um mito: a de que era subversiva. "Ao contrário, o forte da trama é o entretenimento bem-humorado, e não a crítica política." ( $\mathrm{Na}$ verdade, ao longo dos capítulos, a crítica política seguiria presente, com diversas associações irônicas e pessimistas em relação à nova democracia ${ }^{559}$ ). A reportagem da "Veja", no entanto, ressaltava que a novela era bem diferente da peça, e que o autor considerava que, mesmo na Nova República, ainda não havia clima para a obra chegar aos palcos: “A peça mexe com os militares e está proibida até hoje”, disse Dias Gomes à revista ${ }^{560}$. Enquanto “O Berço do Herói” seguia proibida, o governo realizava vários atos públicos que ficaram conhecidos como "descensura", decretando, só no gogó, o fim da censura. O mais famoso, conforme lembra a pesquisadora Beatriz Kushnir, aconteceu em 29 de julho, "no Teatro Casa Grande, templo da resistência contra a ditadura, onde se realizou um 'enterro" "561. Na ocasião, a comissão dos censurados, entre eles Dias Gomes, entregou ao ministro Fernando Lyra o relatório para dar base ao anteprojeto de lei $\mathrm{i}^{562}$.

Por esse dias, Boni conta ter recebido uma ligação do presidente Sarney, que the disse: "Boni, você quer receber a notícia por telefone ou quer vir aqui?" Ele quis saber logo. "Está pronto o decreto acabando com a censura no Brasil. Vai sair amanhã no

\footnotetext{
${ }^{558}$ Ministério da Justiça, Departamento de Polícia Federal, Divisão de Censura de Diversões Públicas, Parecer $n^{\circ}$ 2556/85, 21/6/1985

559 SACRAMENTO, Igor Pinto. Nos tempos de Dias Gomes - A Trajetória de um intelectual comunista nas tramas comunicacionais, doutorado na UFRJ, 2012, p. 404

560 O retorno do mito. Veja, ed. $880,17 / 7 / 1985$, p. 108-109 [matéria não assinada]

${ }^{561}$ KUSHNIR, Beatriz. Cães de Guarda - Jornalistas e censores do AI-5 à Constituição de 1988. São Paulo: Boitempo, 2004, p. 80

562 Pimenta diz temer censura centralizada. Folha de S.Paulo, 30/7/1985, p. 29 [matéria não assinada]
} 
Diário Oficial", falou o presidente. Boni se emocionou (e, novamente, ficou com os olhos marejados, na entrevista para esta pesquisa, ao relatar o episódio). Pediu para o presidente the passar por fax o decreto e marcou a viagem para ir a Brasília agradecerthe pessoalmente ${ }^{563}$.

O que saiu em 13 de agosto no Diário Oficial, no entanto, não foi um decreto, mas o despacho do secretário-geral do Ministério da Justiça, José Paulo Cavalcanti Filho, com as propostas da comissão dos censurados para uma nova legislação para a censura (aquele que havia sido motivo de informe no SNI). O relatório era assinado por Dias Gomes, o jornalista Roberto Pompeu de Souza, o cartunista Ziraldo, o compositor e cantor Chico Buarque, o escritor Antônio Houaiss, a cineasta Ana Carolina Soares e a representante da Conferência Nacional dos Bispos do Brasil, Terezinha Martins Costa. O documento propunha, antes de qualquer coisa, uma mudança de termos: o Conselho Superior de Censura seria substituído por Conselho Superior de Liberdade de Expressão; a Divisão de Censura de Diversões Públicas por Divisão de Classificação de Diversões Públicas. E a Lei da Censura seria a Lei de Defesa da Liberdade de Expressão. A proposta era, basicamente, a de que as obras seriam classificadas por seus produtores, a partir de um regulamento a ser elaborado pelo Conselho Superior de Liberdade de Expressão. Depois, caso houvesse inadequação, poderia ser reclassificada pela Divisão de Classificação. As obras poderiam ser livres ou inadequadas a menores de 12,14, 16 ou 18 anos. No caso da TV, cada faixa etária podia ser exibida a partir de determinado horário (12/20h; 14/22h; 16/23h), sendo que programas não indicados a menores de 18 não poderiam ser veiculados.

O objetivo do despacho era convidar qualquer interessado a enviar sugestões sobre o tema. Com o relatório das comissões e as propostas que chegassem, Coriolano elaboraria um anteprojeto de lei para o ministro Lyra, que o encaminharia ao Congresso no início de 1986. Isso não aconteceu. E, apesar de tantos discursos e do "show 'Fim da Censura"" no Teatro Casa Grande, como ironizou Paulo Francis ${ }^{564}$, nada foi mudado na legis lação até a Constituição de 1988. Mas o "fim da censura" colou. Na lembrança de Boni, ainda que a abolição oficial só fosse ocorrer na Constituição de 1988, Lyra "criou novos mecanismos dispensando a censura prévia e ordenando o fechamento da

\footnotetext{
563 Entrevista de Boni à autora.

${ }^{564}$ FRANCIS, Paulo. Ave Sarney. Folha de S.Paulo, 8/2/1986, p. 39
} 
DCDP" 565 . Mesmo para Dias Gomes, diretamente envolvido nas discussões, ficou na memória que realmente a censura fora abolida nesse início da Nova República, conforme escreveria em sua autobiografia, em 1998:

\section{Abolida a Censura Federal -e participei dessa abolição como} $\underline{\text { membro de uma comissão constituída pelo ministro da Justiça, Fernando }}$ Lyra, para esse fim- [grifo nosso] colocava-se para a chamada "dramaturgia de resistência" um sério problema: não tinha mais sentido fazer uso da metáfora e da analogia. Por outro lado, 20 anos haviam se passado desde que os caminhos da nossa dramaturgia haviam sido obstruídos manu militari, $\mathrm{e}$ não se podia ignorar que durante esse tempo o mundo havia mudado, até mesmo a forma de leitura sofrera alteração com a "revolução" audiovisual. Tornava-se necessária, portanto, uma nova linguagem para um novo tempo. Essa constatação levou nossos dramaturgos a um estado de perplexidade que perduraria durante toda a década de 1980.566

Certamente os tempos eram outros, com avanços e retrocessos rumo à democracia, o que exigia nova abordagem por parte da produção cultural. Mas a Censura Federal não estava abolida. Apenas se transformando, "camaleonicamente". 


\subsection{Capítulo 15}

\section{Tô certo ou tô errado?}

A novela símbolo da Nova República e da volta da liberdade de expressão foi objeto de um calhamaço de 597 páginas na Divisão de Censura de Diversões Públicas. Outras 156 seriam acrescentadas entre 1987 e 1988, quando a Globo exibiria "Roque Santeiro" no "Vale a Pena Ver de Novo", e os censores voltaram a atuar nessa reprise, cortando os capítulos um por um de forma a permitir a exibição em horário livre. Ainda que parte da papelada possa parecer protocolar, como os 114 requerimentos encaminhados pela Globo para o agendamento de exibição prévia dos capítulos para censores, o volume de documentos obtidos para esta pesquisa indicam que, naquele "novo" Brasil de 1985, a temática do mito e dos falsos heróis seguia mais do que atual.

Os dez capítulos liberados sem cortes foram avaliados antes da estreia. Os primeiros a serem analisados depois, já sob o impacto da explosão de audiência, foram o 11 e o 12 . O 11 passou ileso, mas o 12 foi o primeiro a ser rabiscado, para cortar uma cena em que Zé das Medalhas (Armando Bogus) agride fisicamente a mulher, Lulu (Cássia Kiss) ao vê-la maquiada, com vestido de festa, e saber que ela havia ido conhecer a boate Sexus ${ }^{567}$. A Globo recorreu. Duarte F. Franco, cujo cargo na emissora era a de assessor de censura e que assinaria todos os recursos da novela, escreveu para Coriolano em 8 de julho pedindo a anulação do corte, alegando que "a cena atingida nada mais é do que uma discussão entre um marido enciumado e sua esposa". O chefe da censura cedeu. Nesse mesmo dia, contudo, um parecer via problemas no capítulo 15 , em uma cena em que as beatas brigavam com as mulheres da boate. As censoras determinam corte no xingamento de Matilde (Ioná Magalhães), dona da Sexus, em que ela diz "sua puta, vaca de presépio, cachorra, cretina, papa-hóstia". Ao receber o relatório, em 9 de julho, Coriolano concordou com a supressão de "puta"568. Lulu, que era rejeitada sexualmente pelo marido, voltou a dar trabalho aos censores no capítulo 17, quando disse ao padre Hipólito (Paulo Gracindo): “O Zé me evita há cinco anos. Desde que eu descobri que eu... que eu sentia prazer!" A primeira parte, do "evita há

\footnotetext{
${ }^{567}$ Ministério da Justiça, Departamento de Polícia Federal, Divisão de Censura de Diversões Públicas, Parecer $n^{\circ}$ 3082/85, 2/7/1985

568 Ministério da Justiça, Departamento de Polícia Federal, Divisão de Censura de Diversões Públicas, Parecer n ${ }^{\circ} 3097 / 85$, 8/7/1985
} 
cinco anos", tudo bem. Mas a do "descobri que eu sentia prazer", não. As censoras consideraram inadequado ao horário, "por enfocar uma problemática adulta, ou seja, a rejeição sexual por parte do marido ao constatar o prazer da esposa"569.

A chefia parecia tender a uma liberalidade maior do que as técnicas designadas para os pareceres (todas as pareceristas de "Roque" eram mulheres), e algumas sugestões de cortes acabavam barradas por Coriolano ou até pelos chefes intermediários, como a do capítulo 17. Yêda Lúcia Netto e Izabel Azevedo sugeriram retirar a expressão "se borrar de medo", dita por Porcina no capítulo 20. Chefe direta delas, Maria Aurineide Pinheiro considerou a supressão proposta "irrelevante"570.

Mas pouco depois, no capítulo 24, um alerta das mesmas censoras mobilizou a chefia. No parecer, elas sugeriram suprimir a frase "É preciso tirar o diabo do corpo", dita por Zé das Medalhas quando finalmente resolveu se relacionar sexualmente com a mulher. O aviso, no entanto, dizia respeito ao personagem João Ligeiro (Maurício Mattar), irmão caçula de Roque Santeiro. O texto era nebuloso: "Alertamos a chefia quanto à permanência de situações referentes a algum tipo de comportamento negativo de João Ligeiro, não suscitado na sinopse" ${ }^{\text {571 }}$. Coriolano concordou com o corte do "diabo no corpo" e, no mesmo dia que recebeu o parecer, 18 de julho, enviou oficio à Globo para "solicitar esclarecimentos mais detalhados sobre a telenovela 'Roque Santeiro', no que tange às situações ligadas ao personagem João Ligeiro, caracterizado na sinopse como vaqueiro destemido" $" 572$.

O que a Censura evitava perguntar com todas as letras era: "João Ligeiro é gay?" De fato, na caracterização do personagem da sinopse, está dito que "ninguém como ele para domar um burro bravo ou conduzir uma boiada". Mas, no resumo da história, os censores haviam deixado passar (ou fingiram não perceber) o trecho que dizia que, "devido à profanação da cidade", coisas estranhas vinham acontecendo, como o fato de João, "vaqueiro ágil no laço, conhecido e temido como homem valente (valentia digna de seu saudoso irmão)", estar agora, com 18 anos, "a engordar" e, o pior, "a barriga the

\footnotetext{
${ }^{569}$ Ministério da Justiça, Departamento de Polícia Federal, Divisão de Censura de Diversões Públicas, Parecer $\mathrm{n}^{\mathrm{O}} 3107 / 85,11 / 7 / 1985$

${ }^{570}$ Ministério da Justiça, Departamento de Polícia Federal, Divisão de Censura de Diversões Públicas, Parecer $\mathrm{n}^{\circ} 3111 / 85,15 / 7 / 1985$

${ }^{571}$ Ministério da Justiça, Departamento de Polícia Federal, Divisão de Censura de Diversões Públicas, Parecer $\mathrm{n}^{\circ} 3118 / 85,18 / 7 / 1985$

572 Ministério da Justiça, Departamento de Polícia Federal, Divisão de Censura de Diversões Públicas, ofício $\mathrm{n}^{\circ} 1.293 / 85-\mathrm{SE} / \mathrm{DCDP}$
} 
trouxera maneirismos delicados de mulher, chegando-se a suspeitar que estivesse para dar à luz”.

A Globo mandou um adendo à sinopse (que não consta da documentação da DCDP guardada no Arquivo Nacional) e solicitou a anulação do corte da frase do “diabo no corpo", de Zé das Medalhas, entendendo que "a fala atingida não implica em ofensa à moral e aos bons costumes". Coriolano indeferiu, "tendo em vista que o corte assinalado foi efetuado em razão do erotismo grosseiro e vulgar de que foi revestida a situação e não em função dos diálogos"573.

O medo da presença de homossexuais na trama aumentou quando surgiram dois costureiros, personagens completamente secundários que logo deixariam a história, para fazer o vestido de noiva de Porcina. De acordo com o parecer, ambos tinham "atitude ostensivamente efeminada, contrariando o que recomenda instrução normativa" da DCDP. As censoras ponderaram que o "exagero" das cenas constituía "uma espécie de sátira de tal comportamento", além da "brevidade do enfoque", o que tornaria possível a liberação para as $20 \mathrm{~h}^{574}$. Pelo sim, pelo não, Coriolano achou prudente logo oficiar a Globo, mas sem deixar a verdadeira preocupação sair do armário: "No que diz respeito aos personagens Jurandir e seu secretário, solicitamos total observância das instruções normativas da DCDP'575. No capítulo 40, foi cortada uma cena que insinuava levemente, sem nenhum contato físico, o envolvimento de Jurandir com um motorista de caminhão ${ }^{576}$.

O ano de exibição de "Roque Santeiro", 1985, está inserido no terceiro momento de repressão à cultura da ditadura, na divisão do historiador Marcos Napolitano. Apesar de ser o primeiro sem o governo militar, é ainda considerado em razão do não desmanche imediato do aparelho repressivo. Enquanto o primeiro (1964 a 1968), como dissemos, no qual foi censurada "O Berço do Herói (1965), havia se concentrado em “dissolver as conexões entre a 'cultura de esquerda' e as classes populares", e o segundo (1969 a 1978), quando houve a proibição de "Roque Santeiro" (1975), em "reprimir o

\footnotetext{
${ }^{573}$ Ministério da Justiça, Departamento de Polícia Federal, Divisão de Censura de Diversões Públicas, Ofício $\mathrm{n}^{\circ} 1.354 / 85-\mathrm{GAB} / \mathrm{DCDP}, 1 / 8 / 1985$

${ }^{574}$ Ministério da Justiça, Departamento de Polícia Federal, Divisão de Censura de Diversões Públicas, Parecer $n^{\circ}$ 3127/85, 24/7/1985

575 Ministério da Justiça, Departamento de Polícia Federal, Divisão de Censura de Diversões Públicas, Ofício $n^{\circ} 1.307 / 85-S E / D C D P, 24 / 7 / 1985$

576 Ministério da Justiça, Departamento de Polícia Federal, Divisão de Censura de Diversões Públicas, Parecer no 3161/85, 7/8/1985
} 
movimento da cultura como mobilizadora do radicalismo da classe média", esse terceiro período, de 1979 a 1985, "teve como objetivo central controlar o processo de desagregação da ordem política e moral vigentes, estabelecendo limites de conteúdo e linguagem". "A ênfase do controle censório recaiu "na moral e nos bons costumes", explica o historiador. Nesse contexto, ele analisa, o Conselho Superior de Censura, "espécie de instância revisora da censura com representantes da sociedade civil", foi instalado, em 1979, “visando dar uma roupagem 'legítima' e 'intelectualizada' para um atividade muito malvista pelas parcelas escolarizadas da sociedade. No entanto, em linhas gerais, o controle policial sobre a oposição cultural ao regime arrefeceu" 577. Apesar do arrefecimento, a retomada da democracia no governo Sarney (19851990) foi marcada por "rápidas, mas ainda hesitantes alterações de cenários e atores", como nos lembra Kushnir. "Idas e vindas, avanços e retrocessos em um momento de sedimentação pontuaram esse período. Havia uma lacuna entre as propostas apresentadas e as ações efetivamente realizadas. ${ }^{578 "}$

A documentação da censura a "Roque Santeiro" de 1985 expõe todos esses aspectos, do foco na "moral e nos bons costumes", apontado por Napolitano, sendo a questão sexual a preferida da tesoura, às idas e vindas do período ressaltadas por Kushnir, com os censores ora se mostrando mais rígidos, ora mais liberais. Dessa forma, a relação entre a TV e a Censura que marcou a ditadura, de permanente negociação e tensão, conforme a análise de Nahuel Ribke, foi mantida durante a exibição da "novela da Nova República", com a Globo tendo de permanentemente solicitar a revisão de vetos.

Às vezes, a negociação girava em torno de temas, digamos, prosaicos. Como no capítulo 53, quando se determinou o corte de uma cena em que uma seringa com soro antiofídico é aplicada por um enfermeiro no Beato Salu (Nelson Dantas). O material havia sido deixado no hospital onde ele estava internado por um capanga de Sinhozinho Malta, a fim de matar Salu, que vira Roque e poderia revelar à cidade que o herói estava vivo. O objetivo do veto, segundo o parecer, seria "aliviar a tensão" da novela ${ }^{579}$. Isso obrigou a Globo a recorrer a Coriolano, argumentando que a aplicação da seringa

\footnotetext{
577 NAPOLITANO, Marcos. 1964 - His tória do regime militar brasileiro. São Paulo: Contexto, 2014, p. 101

578 KUSHNIR, Beatriz. Cães de Guarda - Jornalistas e censores do AI-5 à Constituição de 1988. São Paulo: Boitempo, 2004, p. 75

${ }^{579}$ Ministério da Justiça, Departamento de Polícia Federal, Divisão de Censura de Diversões Públicas, Parecer no 3190/85, 19/8/1985
} 
"decorre de um acidente, ou seja, de um equívoco do enfermeiro, e não da tentativa de assassinato". Além disso, esclareceu a emissora, "Salu não morrerá". O recurso foi aceito.

A preocupação com a saúde do Beato Salu não era só da máquina estatal da "Nova República". O País inteiro estava grudado na novela. Depois de a "Veja" ter registrado o estouro de audiência das três primeiras semanas, a imprensa iria cravar, entre o final de julho e o mês de agosto, que "Roque Santeiro" era o maior fenômeno da história da televisão brasileira. Reportagens e mais reportagens traziam números, entrevistas com sociólogos, com a equipe de produção e Dias Gomes. No registro jornalístico, não parecia haver um senão, falava-se em "unanimidade", a nação estava de joelhos para o falso herói, e jornais e revistas o saudavam como mártir da "Nova República", como mostram trechos a seguir:

\section{A NOVELA CONQUISTA O PAÍS}

(Folha de S.Paulo, 31/07/1985)

É um prato cheio para teses sociológicas sobre a permanência do mito no imaginário brasileiro. Nenhuma novela conseguiu, até o momento, forjar uma força catalisadora tão poderosa quanto "Roque Santeiro", batendo por duas semanas consecutivas todos os recordes de audiência no horário [...]

Quem explica o sucesso [...] é o próprio "pai” da novela, proibida pela Censura da "Velha República" [...]: "Por ironia, a Censura acabou 'ajudando' desta vez. Talvez agora seja a hora certa de 'Roque Santeiro' ir ao $\operatorname{ar}[\ldots] "$

[Aguinaldo Silva:] "De certa forma, o grande sucesso de 'Roque Santeiro' era esperado, porque o público reconhece, efetivamente, o Brasil na novela, através da figura do herói, mitificado por uma comunidade assolada pelo "milagre brasileiro". 580

\section{E O SUCESSO DEZ ANOS DEPOIS}

(Jornal da Tarde, 8/8/1985)

[...] As perguntas, como não poderia deixar de ser, se voltam para as expectativas do escritor na Nova República, que para ele é apenas uma

580 FILHO GONÇALVEZ, Antonio. "Roque Santeiro": A novela conquista o País. Folha de S.Paulo, $31 / 07 / 1985$, p. 40 
“velha que fez plástica". Não nega, porém, que os tempos agora são de mais liberdade, tanto que "Roque Santeiro" está no ar [...]

Mas ninguém, na verdade, quer deixar o assunto política estender-se por muito tempo, e uma repórter de TV arrisca uma última e curiosa pergunta:"Dias, com quem fica o Sinhozinho Malta no fim da novela?"581

\section{A FÓRMULA QUE TINHA TUDO PARA DAR CERTO}

(Folha da Tarde, 8/8/1985)

“O sucesso é como uma mágica, a gente não pode explicar, senão perde a graça.” Dias Gomes diz que essa é a resposta que tem dado quando alguém lhe pergunta sobre o êxito da novela "Roque Santeiro", que, depois de dez anos de censura, já alcançou, em dias alternados, o maior número de pontos de audiência no horário nobre das 20 horas. ${ }^{582}$

\section{DIAS GOMES}

(Diário Popular, 11/8/1985)

[...] A novela "Roque Santeiro" atinge um dos maiores ibopes já conseguidos no horário das oito [...]

Além disso, Dias Gomes é um dos componentes da Comissão de Alto Nível do Ministério da Justiça responsável pelo sepultamento da censura no País. Como se vê, motivos não faltam para a euforia desse autor [grifo nosso].

[...] “Algumas das sugestões dessa comissão já foram aceitas e já estão sendo adotadas. Dentre algumas que podem ser aceitas está a trans formação da censura em um órgão classificatório de espetáculos -de acordo com a faixa etária- e a extinção do Conselho Superior de Censura, além da criação do Conselho Superior da Liberdade de Expressão. ${ }^{583}$

\section{MANIA NACIONAL}

Em suas primeiras semanas, a novela "Roque Santeiro" alcança índices de audiência que as outras só conseguem no final

${ }^{581}$ RICCA, Regina. A recriação de "Roque Santeiro". E o sucess o, dez anos depois. Jornal da Tardem $8 / 8 / 1985$

582 BRANDÃO, Hermínia. "Roque Santeiro", a fórmula que tinha tudo para dar certo. Folha da Tarde, 8/8/1985

583 Dias Gomes. Diário Popular, 11/8/1985 [matéria não assinada] 
(Isto É, 14/8/1985)

As noites atribuladas do empresário e playboy paulista Chiquinho Scarpa, 33 anos, não atrapalham sua mais recente mania: assistira todos os capítulos da novela "Roque Santeiro" [...]

O escritor e jornalista mineiro Roberto Drummond, 48 anos, que até hoje não perdeu um só capítulo de "Roque", teve até que mudar o horário da ginástica que faz com a filha Beatriz, 13 anos. Ela o acompanha. "Minha filha curtia rock'n roll, agora curte Roque Santeiro.” [...]

Em Brasília, o presidente José Sarney não se conteve:telefonou ao ator Paulo Gracindo para elogiar o seu padre Hipólito, fiel representante da igreja tradicionalista em Asa Branca, a terra de Roque Santeiro. Até o progressista dom Paulo Evaris to Arns, cardeal-arcebispo de São Paulo, diverte-se com as rabugices do velho padre. E, quando perde um capítulo, é acudido por irmã Lourdes, uma de suas auxiliares, que lhe conta as últimas fofocas. No Rio, o historiador marxista Nelson Werneck Sodré, 74 anos, que considera a televisão uma "imbecilização em massa", mudou de time: agora se reúne com a família para ver "Roque Santeiro".

Difícil, na verdade, encontrar quem não veja o maior sucesso da carreira do novelista Dias Gomes, 58 anos, e da história da Rede Globo. Daí os fantásticos índices de audiência. Na quinta-feira, $1^{\circ}$ de agosto, por exemplo, no Rio, 90 pontos para a novela das 8 -o que significa dizer que, exatamente às $20 \mathrm{~h} 30 \mathrm{~m}$ daquela noite, $97,8 \%$ de todos os aparelhos ligados na Grande Rio sintonizavam "Roque", marca absolutamente inédita para um $34^{\circ}$ capítulo.

Em São Paulo, onde as novelas conquistam sempre 10 a 15 pontos inferiores aos cariocas, "Roque Santeiro" atingiu 85 pontos na segunda-feira, 15 de julho, is to é, $92,4 \%$ de todos os televisores ligados na Globo naquela noite.

O recorde nacional de audiência, até a quarta-feira passada, estava com Salvador: 94 pontos no dia $1^{\circ}$ de agosto, o que chega bem perto de $100 \%$ dos aparelhos ligados. Índices como esses, até então, só tinham sido alcançados nos dez últimos capítulos das mais bem sucedidas produções da Globo -como "Irmãos Coragem", "Selva de Pedra" e "Pai Herói”, todas de Janete Clair. Extrapolando os índices das capitais para todo o País, o diretorexecutivo do Ibope, Carlos Augusto Montenegro, 31 anos, não hesita em afirmar: "Dos 18 milhões de domicílios com aparelhos de TV no Brasil, 80\% -mais de 14 milhões- estão ligados em 'Roque Santeiro'.” [...] 
Espelho do Brasil, a Rede Globo parece nunca ter refletido tão nitidamente as várias nuances do caráter nacional. “'Roque Santeiro' foi a maneira que a Globo encontrou de marcar a passagemda Velha para a Nova República", [grifo nosso] explica Paulo Ubiratan [...]

"Criou-se uma verdadeira neurose diante do sucesso", observa Dias Gomes. "O índice de audiência atingiu pontos tão altos que todos estão apavorados com meda da queda.” [...]

"Essa novela é um bendito deboche, que nos conduz a uma revisão crítica de toda a nossa atitude diante do povo", acredita o ministro da Desburocratização, Paulo Lustosa, 40 anos, que se considera uma "macaca de auditório" de Dias Gomes. Para o ministro, "Roque Santeiro" faz u ma apreciação crítica da sociedade brasileira, do comportamento das elites e dos vícios do processo político. E mostra também a exploração da crendice popular e a industrialização da esperança do povo. "A televisão brasileira sempre foi alienante. Essa novela repõe a realidade dentro da televisão", diz o historiador marxista Nelson Werneck Sodré. ${ }^{584}$

\section{UM TERÇO DO PAÍS DE OLHO NA TV}

(Isto É, 14/8/1985)

Nunca tantos brasileiros riram juntos como agora: com a média altíssima para início de novela-em torno de 80 pontos na semana passada, "Roque Santeiro" está cutucando cerca de 43,2 milhões de pessoas, um terço da população do País. Além do ineditismo e alcançar audiências só registradas nas semanas finais de uma novela, o Ibope identificou também em "Roque" um fato novo: em "São Paulo", onde um mercado fortemente competitivo dá à Globo índices sempre muito inferiores aos do Rio de Janeiro, a audiência tem encostado nos números cariocas e ultrapassado em muito a média normal da cidade para o horário, que ficava sempre entre $50 \mathrm{e}$ $60 \%$ dos domicílios com televisores e, agora, está em torno de 70 pontos [...]

Os números apontam picos de audiência espantosos nas oito grandes cidades em que trabalha o Ibope: 94 pontos em Salvador, 91 em Brasília, 90 no Rio, 86 em Curitiba, 85 em São Paulo, 84 em Porto Alegre e 79 em Belo Horizonte [...]

"Nunca houve na TV nada mais parecido com o Brasil", argumenta Montenegro, que prevê para "Roque Santeiro" um final apoteótico, com

\footnotetext{
${ }^{584}$ Mania nacional - Em suas primeiras semanas, a novela "Roque Santeiro" alcança índices de audiência que as outras só conseguem no final. Isto É, 14/8/1985, p. 32-36 [matéria não assinada]
} 
índices capazes de barrar os mais altos até hoje registrados: a chegada do homem à Lua e a vitória do Brasil na Copa do México. Nestas duas vezes -e só aí- o Ibope registrou 95 pontos, o que significa $100 \%$ do total de televisores ligados..$^{585}$

A associação entre "Roque Santeiro" e a volta da liberdade rendeu até uma provocação a Dias Gomes. Em 6 de agosto, Ruy Castro publicou em sua coluna na "Ilustrada", da "Folha de S.Paulo", uma foto em que o dramaturgo está em um dos eventos de "descensura", à frente de uma faixa em que se lê "Adeus, Censura; Começou a Nova República", acompanhado de Bernadeth Lyzio, 22, sua nova namorada, 40 anos mais nova que ele (e com quem ele iria se casar e ter duas filhas). Abaixo da imagem, uma nota com o título "Liberdade para Dias Gomes" afirmava:

A "Nova República” está rendendo belos dividendos de liberdade para o dramaturgo e novelólogo Dias Gomes. Sua novela "Roque Santeiro" está finalmente no ar pela Rede Globo, depois de ter sido proibida há dez anos pela "Velha Censura". Sua peça “Amor em Campo Minado", que passou catorze anos trancada nas gavetas, foi um sucesso no Rio e estreia quintafeira em São Paulo. E, como se não bastasse, sua nova liberdade lhe permite ser visto nas festivas comemorações pela recém-adquirida liberdade de expressão, ao lado da gatésima Bernadeth, 22 anos -sua fã desde o tempo em que usava coppertone na praia e era obrigada a ir dormir sem poder ver a novela das 8.586

Em um ano em que a revista "Veja" publicou a quase a totalidade de suas capas sobre a política ou a economia do País (39 das 53 capas, 73\%), "Roque Santeiro" foi uma das quatro sobre cultura, sendo a única a respeito da televisão. As outras culturais foram Rock'n Rio (2/1), os Menudos (6/3) e o filme “Amadeus" (26/6) ${ }^{587}$. Para a capa foi escolhida uma foto de Sinhozinho Malta prestes a beijar Porcina, e o título "Roque Santeiro' - Como é feita a novela de maior audiência da história”. Foram sete páginas de reportagens, com detalhes da produção e até entrevista com figurantes (que "se benzem e chegam a rezar" na igreja cenográfica) saudando a novela que até durante a

\footnotetext{
585 Ibidem.

${ }^{586}$ CASTRO, Ruy. Liberdade para Dias Gomes. Folha de S.Paulo, 6/8/1985, p. 30

${ }^{587}$ Porcentagem feita a partir do acervo da revista disponível em acervo.veja.abril.com.br.
} 
"barriga" (parte intermediária da história, quando a audiência normalmente registra uma queda), conseguia "espantosos" 74 pontos de média, atingindo perto de $80 \%$ dos aparelhos ligados no horário, ou seja, 60 milhões de espectadores no País (entre eles até Armando Falcão, o então ministro da Justiça em 1975, que proibira a novela de ir ao ar, "para hoje acompanhá-la assiduamente"). A revista mencionava paralelos entre a novela e a realidade nacional, desde detalhes no cenário, como um quadro mostrando Dom Pedro I e um porta-livros que imitariam objetos semelhantes da sala do presidente José Sarney, até passagens da história, a exemplo de uma cena em que várias pessoas rezavam diante da Santa Casa de Asa Branca para a recuperação de Beato Salu, uma paródia do que havia se dado durante a agonia de Tancredo Neves no Instituto do Coração, em São Paulo. "Ao rir de Asa Branca, o Brasil na verdade está rindo de si mesmo", sentenciou José Wilker na reportagem ${ }^{588}$. A reza do povo na novela funciona, Salu "ressuscita" e surge na praça no momento em que Albano, o padre progressista, iria revelar à cidade que Roque estava vivo. Ao ver o Beato, a população atribui sua cura a mais um milagre de Roque Santeiro, e Albano acaba aceitando que o mito era mais forte do que a verdade ${ }^{589}$.

De fato "Roque Santeiro" foi exaltada como um espelho do País. Se Porcina era a viúva sem nunca ter sido, Sarney era o presidente sem nunca ter sido. Se Roque Santeiro, morto, tornou-se mito, assim havia ocorrido com Tancredo Neves, como analisou Sacramento:

“O Berço do Herói” expõe as dinâmicas do gerenciamento das crenças populares envolvidas na construção de um falso ídolo. "Roque Santeiro", por sua vez, desenvolve a questão da alienação pela idolatria, com referências à corrupção que caracterizava a Nova República, repetindo longa tradição patrimonialista brasileira de manutenção das profundas desigualdades sociais. A as sociação da sacralização de Tancredo Neves à de Roque Santeiro demonstrava não apenas a longa permanência do misticismo como forma de mediação popular com a realidade, mas tornava comparável ao processo de des encanto com a morte do redentor e ao de reencantamento com a sua santificação. 590

\footnotetext{
${ }^{588}$ Um dia em Asa Branca. Veja, ed. 891, 2/10/1985, p. 132-140 [matéria não assinada] 589 Entrevista de Marcílio Moraes à autora, no Rio, em 11/5/2011.

590 SACRAMENTO, Igor Pinto. Nos tempos de Dias Gomes - A Trajetória de um intelectual comunista nas tramas comunicacionais, doutorado na UFRJ, 2012, p. 404-406
} 
Diante de tantas comparações, Dias Gomes brincou em uma entrevista: "A minha sorte é que escrevi essa novela há dez anos, porque senão iam dizer que eu estava sacaneando o Tancredo..."591. Como observaram os pesquisadores no livro "Telenovela - História e Produção", na década de 1980, as novelas "não são somente grandes sucessos de audiência, elas procuram se apresentar, para o público e para a sociedade, como narrativas legitimadas pelos temas políticos que abordam" ${ }^{\text {"592 }}$. Foi exatamente isso que constatou uma pesquisa qualitativa encomendada pela Globo. Realizada no formato de "discussion group" (grupo de discussão), com telespectadoras entre 25 e 45 anos, mostrou que o sucesso de "Roque Santeiro" tinha a ver com o "tom de sátira", o ritmo, o entrosamento entre o elenco e os personagens e que, não assistir à novela "parece estar $\underline{\text { sendo indício de alienação cultural" " [grifo nosso] }}{ }^{593}$. Mais uma ironia da passagem da ditadura para a democracia: não ver novela é que era alienação.

A audiência de "Roque Santeiro" também seguia em alta nas projeções dos capítulos feitas previamente aos censores, que não estavam gostando nada da quantidade de cenas de adultério. No lote dos capítulos 55, 56 e 57, analisados em conjunto, as censoras Izabel Azevedo e Yêda Lúcia Netto Campos assinalaram quatro problemas: o beijo entre Lulu (mulher de Zé das Medalhas) e Roque, a perseguição do lobisomem a Ninon, a ameaça de suicídio de Amparito (amante do prefeito) e a rápida aparição de dois travestis. A censora superior a elas, Maria Aurineide Pinheiro, liberou os três últimos "problemas", mas concordou com o veto ao beijo adúltero entre Lulu e Roque.

\footnotetext{
${ }^{591}$ Revista Comunicações do ISER, n. 16, 11/1985, p. 6-7, apud SACRAMENTO, Igor Pinto. Nos tempos de Dias Gomes - A Trajetória de um intelectual comunista nas tramas comunicacionais, doutorado na UFRJ, 2012, p. 405

592 RAMOS, José Mário Ortiz; BORELLI, Silvia H. Simões. A telenovela diária. In: ORTIZ. Renato; BORELLI, Silvia Helena Simões; RA MOS, José Mário Ortiz. Telenovela - história e produção, $2^{\mathrm{a}}$ edição. São Paulo: Editora Brasiliense, 1991, p. 96

593 ORTIZ, Renato e RAMOS, José Mário Ortiz. A produção industrial e cultural da telenovela. In: ORTIZ. Renato; BORELLI, Silvia Helena Simões; RA MOS, José Mário Ortiz. Telenovela - história e produção, 2 $2^{a}$ edição. São Paulo: Editora Brasiliense, 1991, p. 127
} 
Mais para frente, no capítulo 64, outro corte semelhante, desta vez do beijo do cineasta Gerson do Valle (Ewerton de Castro) e da atriz Linda Bastos (Patrícia Pillar) ${ }^{594}$. A Globo escreveu a Coriolano pedindo o cancelamento do corte, "tendo em vista que o arroubo apaixonado de Gerson não vai além do beijo forçado que ele dá em Linda e que motiva a sequência de cenas cômicas". O chefe da DCDP acolheu o recurso.

Um bloco de 12 capítulos seguiu livre depois dessa troca de correspondência, do $65^{\circ}$ ao $76^{\circ}$. Até que foi cortada uma cena inteira do capítulo 77, que mostrava Roberto Matias (Fábio Jr.) com a ex-mulher (Elisângela) na cama, seminus, "caracterizando que mantiveram relacionamento sexual', conforme apontou o parecer ${ }^{595}$. Depois, no capítulo 81, Dondinha (Cristina Galvão) se despe para se oferecer a João Ligeiro (Maurício Mattar), que a rejeita, dizendo que não a quer, nem a nenhuma outra mulher. Corte $^{596}$. No 91, as censoras implicaram com o diálogo em que Dona Pombinha (Eloísa Mafalda) diz a Flô (Ary Fontoura) que a filha deles, Mocinha (Lucinha Lins), está tão mudada que, "imagina, está usando até desodorante íntimo!"597. E um beijo entre Lulu (Cássia Kiss) e Ronaldo (Othon Bastos) foi censurado no 93, "por caracterizar infidelidade conjugal, colocada de forma justificável para o público"598 (visto que ela era rejeitada sexualmente, além de agredida, pelo marido, Zé das Medalhas).

Nessa leva a partir do capítulo 90, aliás, a tesoura correu solta, principalmente em cima do adultério. Foram suprimidos cenas com beijo entre Lulu e Ronaldo mais uma vez no 94 e entre Gerson e Linda no $95^{599}$. Desse último, novamente, a Globo decidiu recorrer, agora com o argumento de que a novela, em razão do horário eleitoral gratuito, estava começando às $21 \mathrm{~h}$. Não convenceu Coriolano. Ele respondeu que "a abordagem da infidelidade conjugal extrapola o horário previsto para a exibição, mesmo que circunstancialmente tenha sido alterado para após as $21 \mathrm{~h} " 600$. E a Censura seguiu

\footnotetext{
${ }^{594}$ Ministério da Justiça, Departamento de Polícia Federal, Divisão de Censura de Diversões Públicas, Parecer no 4446/85, 30/8/1985

595 Ministério da Justiça, Departamento de Polícia Federal, Divisão de Censura de Diversões Públicas, Parecer $n^{\circ} 4491 / 85,13 / 9 / 1985$

596 Ministério da Justiça, Departamento de Polícia Federal, Divisão de Censura de Diversões Públicas, Parecer $n^{\circ}$ 4518/85, 23/9/1985

${ }^{597}$ Ministério da Justiça, Departamento de Polícia Federal, Divisão de Censura de Diversões Públicas, Parecer $n^{\circ} 4932 / 85,2 / 10 / 1985$

598 Ministério da Justiça, Departamento de Polícia Federal, Divisão de Censura de Diversões Públicas, Parecer $n^{\circ}$ 4939/85, 4/10/1985

599 Ministério da Justiça, Departamento de Polícia Federal, Divisão de Censura de Diversões Públicas, Parecer $n^{\circ}$ 4944/85, 7/10/1985

${ }^{600}$ Ministério da Justiça, Departamento de Polícia Federal, Divisão de Censura de Diversões Públicas, Ofício $n^{\circ} 1.689 / 85-G A B / D C D P, \quad 10 / 10 / 1985$
} 
cortando o tema nos capítulos seguintes. No 96, também foi riscada uma fala de Roque dizendo que as prostitutas existem "porque alguém precisa delas". "Se Deus permite que elas vivam, que elas trabalhem...". Não podia, por emitir "juízo de valor deturpado acerca de prostituição". E uma curiosa distinção foi feita pelas censoras no capítulo 97: Elas vetaram a frase "Joga bosta no ventilador", mas deixaram passar o termo "cocozinho", "porque foi dito de forma menos incisiva e desprovida de agressividade" $" 601$.

Até a apreciação do capítulo 109, ou seja, de mais da metade da novela (que teve 209 capítulos), a Censura parece ter funcionado como se nada houvesse mudado no País, mesmo com Boni ligando "praticamente todos os dias" para reclamar com o presidente Sarney, e de ele sempre responder "Tem que acabar com isso, tem que desmontar, vou falar com o Marco Maciel..." ${ }^{902}$. As censoras que avaliaram os episódios 107, 108 e 109 sugeriram à chefia que alertasse a Globo sobre o clima de "certa angústia e tensão" que envolvia as cenas das tentativas de assassinato a Roque, a mando de Sinhozinho Malta ${ }^{603}$. Assim, em 22 de outubro, Coriolano escreveu à emissora que essa trama determinava "cuidados especiais" da Censura e solicitando "comedimento, de sorte a serem evitados 'cortes' [aspas no original] e a consequente mutilação da obra" 604 . Seria o último ofício encaminhado à emissora sobre a novela, de acordo com a documentação guardada no Arquivo Nacional. A relação entre a DCDP e a Globo mudaria a partir do momento em que, finalmente, a imprensa noticiaria a ação da tesoura.

A coluna "Radar", da revista "Veja", trouxe, na edição de 23 de outubro, uma nota com o título "Censura mutila 'Roque Santeiro", reproduzida a seguir:

\footnotetext{
Vários capítulos da novela "Roque Santeiro", entre os quais os de número 95 e 96, que foram ao ar pela Rede Globo nos últimos dias 12 e 14, sofreram cortes da Censura Federal em Brasília. Fundamentados na tese de que não devem ser mostradas cenas de infidelidade conjugal explícita, os cortes mutilaram momentos mais calorosos entre Lulu (Cássia Kiss) e
}

\footnotetext{
${ }^{601}$ Ministério da Justiça, Departamento de Polícia Federal, Divisão de Censura de Diversões Públicas, Parecer no 4956/85, 10/10/1985

602 Entrevista de Boni à autora.

${ }^{603}$ Ministério da Justiça, Departamento de Polícia Federal, Divisão de Censura de Diversões Públicas, Parecer $n^{\circ}$ 4981/85, 21/10/1985

${ }^{604}$ Ministério da Justiça, Departamento de Polícia Federal, Divisão de Censura de Diversões Públicas, Ofício $n^{\circ}$ 1.722/85-SE/DCDP, 22/10/1985
} 
Ronaldo (Othon Bastos)e entre Linda Bastos (Patrícia Pillar) e Gerson do Valle (Ewerton de Castro). Segundo o teatrólogo Dias Gomes, autor de "Roque Santeiro", a ação da Censura mostra que "a Nova República é uma velha que fez plástica”. O atual responsável pelo roteiro da novela, Aguinaldo Silva, espanta-se como silêncio dos intelectuais. "Eles parecem ter perdido o senso crítico", lamenta. "Se is so acontecesse no governo anterior, estariam todos protestando." 605

No dia seguinte à publicação da nota, Coriolano foi convocado para uma reunião com Fernando Lyra. O ministro proibiu cortes e reafirmou que a Divisão de Censura de Diversões Públicas deveria funcionar como órgão classificatório. Se não fosse possível negociar com os produtores, a Censura deveria simplesmente classificar para outro horário. Mas determinou que as cenas consideradas "muito pesadas" pelos censores deveriam ser enviadas a ele. Coriolano resumiu o encontro à "Folha de S.Paulo": "Foi uma tremenda bronca". Lyra estava "tremendamente irritado" com os cortes a "Roque Santeiro", "por entender que a Censura havia acabado no evento do Teatro Casa Grande, em julho. "Ele não quer que isso se repita enquanto estiver no Ministério da Justiça", afirmou o chefe da DCDP. Horas antes da "bronca", Coriolano almoçara com Dias Gomes em Brasília para "acertar os ponteiros". Aconselhara o dramaturgo a baixar o tom nas cenas de adultério. Os adúlteros não poderiam estar na cama, e a sequência não deveria ter nada que insinuasse que estiveram por lá. Já os beijos, antes vetados, seriam liberados, ele prometera. "Um simples beijo, por exemplo, não caracteriza adultério", sentenciou.

Todo o relato dos encontros em Brasília foram publicados no dia seguinte em uma reportagem no alto de uma página da "Ilustrada", na "Folha", com o título "Beijo, o limite da Censura na novela"606. O texto se concentrava nos cortes recentes, dos capítulos 95 a 98 (adultério, "bosta no ventilador” e prostitutas permitidas por Deus), dos quais reproduzia quatro cenas vetadas. Não falava da ocorrência frequente do problema desde o início da exibição. Dias Gomes deu entrevista dizendo se sentir "tapeado" pelo ministro, pois pensava que a Censura realmente iria acabar a partir do evento no Teatro Casa Grande. "É claro que não tomei as palavras do Lyra ao pé da

605 DIAS, Etevaldo e TEIXEIRA, Hélio. Censura mutila "Roque Santeiro" - coluna Radar. Veja, ed. $894,23 / 10 / 1985$, p. 47

${ }^{606}$ Beijo, o limite da censura na novela. Folha de S.Paulo, 25/10/1985, p. 54 [matéria não assinada] 
letra, mas ele disse que a Censura, em vez de castrar e cortar, apenas classificaria os programas na TV por horários. Agora estou estranhando o código de valores dos censores, arcaicos, de uma moral burguesa totalmente ultrapassada", afirmou o autor, que discutiu o mérito dos vetos às cenas de adultério: "Se uma mulher vive com um homem que a espanca, é uma situação imoral. Se ela procura outro para ser feliz, a situação é moralizante [...] Dizer que ela é adúltera é uma ideia arcaica”. Ele também condenou o que considerou falta de critérios: "Permitem que a Pombinha (Eloísa Malfada) chame as meninas de piranhas toda hora, mas o Sinhozinho não pode dizer 'bosta'? Absurdo também”'. E aproveitou para tentar se vacinar com uma temida interdição dos censores, na trama da paixão do padre Albano (Cláudio Cavalcanti) por Tânia (Lídia Brondi): “Em plena década de 70, fiz [a novela] 'Assim na Terra como no Céu', onde Francisco Cuoco era um padre que se apaixonava e largava a batina. Só quero ver se agora, na 'Nova República', vão proibir a paixão do padre Albano"607.

A "bronca" de Lyra teve efeito imediato, e todos os capítulos analisados a partir daí foram liberados sem cortes. Mas não sem o protesto dos censores. O que se observa nos pareceres que se seguiram é uma verdadeira guerra fria na DCDP. Os primeiros episódios a serem analisados após a determinação de Lyra foram o 110 e o 111 . No $110^{\circ}$ era exibido em "flash back" o beijo entre Ronaldo e Lulu cortado anteriormente, como havia sido combinado no almoço entre Dias Gomes e Coriolano, como uma forma de marcar a mudança de posição do governo, levando ao ar algo antes censurado. No $111^{\circ}$, havia "cena de adultério e de relacionamento sexual anormal entre Ninon e Feijó [Maurício do Valle]". Yeda Lúcia Netto Campos e Maria das Graças Sampaio Pinhati determinaram cortes nos dois casos. Chefe das duas, Maria Aurineide Pinheiro concordou com os vetos, e encaminhou à consideração de seu superior, Raimundo Eustáquio de Mesquita. Ele achou o conteúdo "demasiadamente forte" para o horário, e encaminhou a decisão a Coriolano. Que liberou tudo.

A partir do $112^{\circ}$, as censoras passaram a apontar cenas que consideravam "inadequadas" ao horário, sem dizer diretamente que estavam propondo corte, e encerrando os pareceres sempre com "à sua consideração". No lote entre o 112 e o 115, Maria Aurineide Pinheiro despachou para cima o parecer concordando com as "inadequações" (as mesmas de sempre, com cenas de adultério e de violência), sem

${ }^{607}$ Ibidem para todo o trecho acima. 
falar em veto. $\mathrm{O}$ visto de seu superior, Raymundo Eustáquio de Mesquita, é uma mensagem a Coriolano que vale ser reproduzida:

Sr. Diretor,

Os capítulos ora examinados, conforme depreendemos do parecer $\mathrm{n}^{\mathrm{o}}$ 5002 e do despacho da chefe do SCTR [Maria Aurineide Pinheiro], portam situações consideradas inconvenientes para as 20 horas [...]

Segundo orientação de V. Sa., baseada em determinação do Excelentíssimo Senhor Ministro da Justiça, de que a censura de telenovelas deve ser apenas classificatória, levamos à consideração a liberação dos capítulos apreciados para o referido horário. ${ }^{608}$

Coriolano colocou seu carimbo abaixo da mensagem e sobre ele redigiu: “Liberar, sem os cortes". Entre o 116 e o 118, a própria Maria Aurineide Pinheiro achou por bem já propor a liberação. Em sua consideração, escreveu de uma forma que pode apontar ou um ato falho ou mesmo um protesto velado:

Conforme parecer $\mathrm{n}^{\circ}$ 5008/85, os capítulos 116,117 e 118 da telenovela "Roque Santeiro" poderão ser liberado para o horário estabelecido, ou seja, 20 horas, todavia [grifo nosso], no capítulo 118, foram assinalados, no script, as páginas:

2 - Comentário de Lulu sobre o relacionamento com Ronaldo;

8, 9 - Cena de Zé das Medalhas tentando o suicídio.

Tais situações poderão ser liberadas por não apresentarem maiores implicações. ${ }^{609}$

Com esse "todavia" aparentemente mal-empregado, ela apontava o que considerava inadequado, sem afirmar que eram. No parecer seguinte, sobre os capítulos 119 e 120, seria mais direta. Ratificou as "inadequações" assinaladas pelas censoras (uma a respeito de um diálogo que fala de carência sexual e outra, da troca de beijo e carícias entre Ninon e Feijó, "caracterizando um relacionamento doentio da jovem, que exige de seu parceiro a simulação de atitudes animalescas"), e fez questão de anotar:

\footnotetext{
${ }^{608}$ Ministério da Justiça, Departamento de Polícia Federal, Divisão de Censura de Diversões Públicas, Parecer $n^{\circ}$ 5002/85, 31/10/1985

${ }^{609}$ Ministério da Justiça, Departamento de Polícia Federal, Divisão de Censura de Diversões Públicas, Parecer $n^{\circ} 5008 / 85,1 / 11 / 1985$
} 
“Tais passagens, semelhantes as já exploradas nos capítulos 111 e 112, foram liberadas pelo Sr. Diretor da DCDP, assim sendo, considero-as passíveis de liberação" ${ }^{\prime 610}$.

A partir do 121, analisado em 5 de novembro, os pareceres passaram a fazer resumos dos capítulos (apenas anotando cenas como a strip-tease de Ninon, de encontro amoroso entre Lulu e Ronaldo e da atração entre o padre Albano e Tânia), decidindo pela liberação, "seguindo a linha dos anteriores". Mas algo quebrou essa rotina "liberal". No capítulo 174, o padre Albano decide viver com Tânia, sem abandonar o clero. As censoras alertaram seus superiores. Maria Aurineide deu seu visto deixando "à consideração" da chefia, que era interinamente ocupada por Maria Lívia Fortaleza, no lugar de Raymundo Eustáquio de Mesquita. Esta sublinhou que a "situação é contrária aos princípios éticos religiosos" e sugeriu que fosse feita "remontagem, pois poderá gerar conflito entre o clero". "Corte", então, ganhava o apelido eufemístico de "remontagem". Coriolano seguia firme. "Libere-se sem cortes", assinalou.

A guerra fria se acirrou no parecer do capítulo 181. As censoras anotaram duas "inadequações": a fala de Gerson a Tito: "Pega uma vela daquelas bem compridas, sabe? E resolve o teu problema”. Entre parênteses, havia a explicação: “(Sugestão para introduzir no ânus)"; Sinhozinho Malta diz: "É seu Roberto Matias que bota ele pra comer pedra... enquanto ele come outras coisas..." [grifo original], seguida de esclarecimento: "(Referência ao relacionamento sexual)". Maria Aurineide concordou com a liberação do capítulo, com "exceção das falas maliciosas, de cunho grosseiro". E escreveu “À SUA CONSIDERAÇÃO”, usando, pela primeira vez, letras maiúsculas. Coriolano entendeu o recado e respondeu à altura: "Para liberar sem as supressões (artigo $3^{\circ}, \S \mathrm{f}$, do decreto $\mathrm{n}^{\mathrm{o}} 20.493 / 46$ )" ${ }^{\prime 611}$.

O decreto da Censura feito pouco após o fim do Estado Novo, em 1946, o mais utilizado no cerceamento à cultura durante a ditadura militar (e que justificaria as proibições de "O Berço do Herói” e da primeira versão de "Roque Santeiro"), agora, ironicamente, era escalado para liberar um "come" e um "pega uma vela bem comprida e resolve o seu problema".

A alínea ' $\mathrm{P}$ ' do artigo $3^{\circ}$, mencionada por Coriolano, afirma que compete ao chefe da Censura "avocar, para os efeitos de revisão, qualquer matéria afeta às

\footnotetext{
${ }^{610}$ Ministério da Justiça, Departamento de Polícia Federal, Divisão de Censura de Diversões Públicas, Parecer $n^{\circ}$ 5014/85, 5/11/1985

${ }^{611}$ Ministério da Justiça, Departamento de Polícia Federal, Divisão de Censura de Diversões Públicas, Parecer $n^{\circ} 31 / 86,16 / 1 / 1986$
} 
deliberações dos censores, inclusive a já censurada, quando haja manifesto desacordo entre os atos do censor e os preceitos regulamentares e instruções transmitidas". Se o chefe da DCDP tomara uma "bronca" do ministro, agora a estava retransmitindo aos subordinados por escrito.

Um último "suspiro" viria de Maria Angélica R. de Resende, alertando novamente sobre o desejo do padre Albano de viver maritalmente com Tânia, no capítulo 188, mas Coriolano carimbou um "para liberar em versão integral"612.

$\mathrm{Na}$ imprensa, a censura sairia de cena após o acerto entre Lyra, Coriolano e Dias Gomes. Na edição seguinte à da reportagem "Beijo, o limite da Censura", a "Folha" publicaria outra matéria sobre "Roque Santeiro", demonstrando para onde o noticiário se encaminharia: "No fim, Roque mata Navalhada" ${ }^{613}$. Com o País absorvido pela história, os jornais tratariam de tentar antecipar o seu desfecho. A matéria ainda faria conexões entre o enredo e a censura: "A mentira de que Roque foi morto [...] por defender a igreja vira verdade. Ele se transforma realmente no salvador de Asa Branca [...] O fim da censura também virou verdade, após a intervenção do ministro Fernando Lyra, e esta impressão de realidade [...] garante o sucesso de 'Roque Santeiro'”. Em entrevista, Dias Gomes reafirmou que "o Brasil não pode viver sem mitos", o que foi comprovado, segundo ele, pelos cortes à novela, que desmascararam "o mito do fim da censura”: “A 'Nova República' é um mito, Tancredo Neves era um mito, o milagre brasileiro foi outro mito. Infelizmente vamos precisar de muitos mitos ainda. É uma maneira de se agarrar a esperanças". A reportagem segue afirmando que "agora, o mito do fim da censura voltou a vigorar, por ordem expressa do ministro da Justiça"614.

Mas o mito do fim da censura era frágil. Com o sucesso da novela, um empresário se interessou em montar a peça que the dera origem, "O Berço do Herói”, proibida desde 1965. Mas, conforme relatou Dias Gomes à "Folha", em 9 de novembro, "foi desaconselhado por militares": "A peça discute o mito do herói de guerra e os militares não admitem isso [...] Mas espero um dia vê-la em cartaz" ${ }^{615}$. Isso só aconteceria mais de três décadas após a censura, em 25 de outubro de 1996, quando a

\footnotetext{
612 Ministério da Justiça, Departamento de Polícia Federal, Divisão de Censura de Diversões Públicas, Parecer $n^{\circ} 43 / 86,22 / 1 / 1986$

613 CEZIMBARA, Marcia. No fim, Roque mata navalhada. Folha de S.Paulo, 26/10/1985, p. 47

614 Ibidem.

${ }^{615}$ As muitas vidas de “Roque Santeiro". Folha de S.Paulo, 9/11/1985, p. 60 [matéria não assinada]
} 
peça finalmente estrearia profissionalmente, em forma de musical, dirigido por Bibi Ferreira e com o nome mudado para "Roque Santeiro"616.

Já na fase final da novela, que teria o último capítulo exibido em 22 de fevereiro, o que virou notícia, além das especulações sobre o seu desfecho, foi o desentendimento entre Dias Gomes e Aguinaldo Silva. Os colaboradores, Marcílio Moraes e Joaquim Assis, há muito vinham tendo de botar panos quentes em discordâncias dos dois sobre o rumo de personagens. Mas o que realmente deixou o criador de "Roque" enciumado foi o fato de Aguinaldo ter começado a aparecer muito na imprensa falando sobre a novela, inclusive a respeito do final da história. Além de discordar desse tipo de antecipação da trama (que tempos depois seria chamado de "spoiler"), Dias acreditava que o desfecho deveria ser dado por ele, até porque isso já estava previsto na sinopse (Roque morreria, como o cabo Jorge de "O Berço do Herói”, mas o autor mudou de ideia, deixando o falso herói vivo na novela). Boni foi acionado para informar a Aguinaldo que o final ficaria nas mãos de Dias. Houve uma tentativa de disfarçar a briga, com a sugestão de que Aguinaldo dissesse que decidira entregar o final ao criador de "Roque Santeiro" como uma homenagem. Mas nenhum dos dois tinha personalidade para tanta encenação. Aguinaldo deixou a novela antes mesmo do combinado. Dias a retomou a partir do capítulo 162, e a briga tornou-se pública, com Aguinaldo declarando que "na ficção, Roque Santeiro pode até vencer, mas na vida real Sinhozinho Malta sempre triunfa" (as provocações iriam esquentar ao longo dos anos, com Dias chamando Aguinaldo de "pessoa feia por dentro e por fora", e este dizendo que o desafeto "usava dentadura e aquela peruquinha ridícula de Gepeto"617).

Na edição de dezembro da "Playboy", Dias foi o entrevistado. Em uma conversa que ocupou 12 páginas e que tratou desde o longínquo início da carreira até a vida sexual com a nova namorada, falou-se brevemente sobre a censura na Nova República:

\footnotetext{
${ }^{616}$ MAGALHÃES, Simone. "Esta peça é maldita”. O Dia, Caderno O Dia D, 24/10/1996, p. 3 ${ }^{617}$ As informações sobre a briga foram coletadas em entrevistas com Boni, Bernadety Lyzio, Marcílio Moraes e Joaquim Assis, além de reportagens da época, entre elas: Dias retoma "Roque". Jornal do Brasil, 19/11/1985 [matéria não assinada]. E volta o autor da telenovela "Roque Santeiro". O Estado de S. Paulo, 20/11/1985 [matéria não assinada], Troca de mãos. Veja, ed. 899, 27/11/1985, p. 32 [matéria não assinada], onde está a frase de Aguinaldo; as ofensas posteriores estão em Dias Gomes acusa Aguinaldo Silva de megalomania aguda e receita internação. Jornal do Brasil, 23/01/1992, p. 1 [matéria não assinada], para "pessoa feia por dentro e por fora"; e CASTRO, Ruy. Playboy entrevista Aguinaldo Silva. Playboy, ed. 204, 7/1992, p. 31 (“dentadura e peruquinha); Aguinaldo Silva respondeu à autora que preferia não conceder entrevis ta sobre "Roque Santeiro".
} 
[Mudou] Muito pouco. Todo mundo esperava que não houvesse mais censura alguma, e is so não ocorre. Pelo simples fato de os censores serem os mesmos ainda, com as mesmas cabeças. Por mais que o ministro da Justiça, Fernando Lyra, tenha declarado no Teatro Casa Grande a extinção da censura -aliás, contando coma minha presença na mesa, pois faço parte da comissão encarregada de estudar a questão da censura-e apoie a ideia de uma classificação, apenas, de peças, filmes e livros, a censora continua. Passa o "Roque Santeiro", passa o “Amor em Campo Minado", mas a censura continua usurpando frases, trechos, cenas. 618

Pouco antes da publicação desta entrevista, no final de novembro, um episódio chamara a atenção para a complexidade do tema. O filme "O Último Tango em Paris", de Bertolucci, classificado pela DCDP para maiores de 18 anos, fora proibido pelo Juizado de Menores paulista de ser exibido em São Paulo pela TV Bandeirantes. A decisão se baseara no Código de Menores, de 1980, que vetava a apresentação, em televisão, de programas liberados para maiores de 18 anos. Esse aspecto inclusive havia sido mantido nas propostas para nova legislação da censura feitas pela comissão da qual Dias Gomes fazia parte.

Em 14 de dezembro, a "Ilustrada", da "Folha", publicou uma reportagem acompanhada de curiosa charge do cartunista Glauco, na qual um repórter pergunta a um juiz: "E a tesoura? Ainda continua?", a que o magistrando responde "Não, agora é só cortador de unha", exibindo o objeto. Na matéria, há uma passagem elucidativa:

A proibição [da exibição do filme na TV], além de demonstrar o fôlego do ideário moralista e conservador em regiões como São Paulo, consideradas modernas e liberais, chamou a atenção para um fato de que poucos haviam se dado conta: os dispositivos de censura no Brasil não estão concentrados da Divisão de Censura da Polícia Federal. Há, legalmente, um exército auxiliar, formado pelos juízes de menores [grifo nosso]. ${ }^{619}$

Aí estava um nó dificil de desatar mesmo com o fim oficial da Censura do Estado no Brasil, determinado na Constituição de 1988, que só então revogaria o todo aparato legal anterior e iria transformar a proposta classificatória em lei. A

\footnotetext{
${ }^{618}$ COURI, Norma. Playboy entrevista Dias Gomes. Playboy, ed. 125, 12/1985, p. 78

619 GONÇALVES, Marcos Augusto. O poder de vetar do Juizado de Menores. Folha de S.Paulo, 14/12/1985, p. 49
} 
"judicialização" da censura, como pontua Maria Cristina Castilho Costa, coordenadora do Observatório de Comunicação, Liberdade de Expressão e Censura (Obcom), da ECA-USP, iria se recrudescer com o passar dos anos democráticos, chegando a assemelhá-los aos da ditadura em termos de controle da produção simbólica ${ }^{620}$.

E essa sobrevivência da repressão, como dissemos, seja ela exercida pelo poder executivo ou pelo judiciário, tinha como base o apoio da sociedade, ou ao menos de uma parte dela. Em 1986, ano do encerramento de "Roque Santeiro", o governo recebeu um abaixo-assinado com 40 mil assinaturas da "Campanha nacional contra o erotismo e a pornografia nos comerciais e novelas exibidos na TV'. Os signatários defendiam uma "Nova República liberal, não libertina"621. Como aponta Kushnir:

Persistia uma parcela da sociedade ainda desejosa de tutela, como
também um governo interventor na seara pública e privada. Uma fatia mais
conservadora solicitava que o Estado ainda lhe dis sesse o que ver, a
"protegesse" e tirasse de seu mundo algo que lhe ficou como pornografia. ${ }^{622}$

A poucos dias do fim da novela, em 5 de fevereiro, o presidente Sarney, pressionado pela Igreja Católica e por manifestações da sociedade, como uma passeata de mulheres em Belo Horizonte, proibiu a exibição no País do filme "Je Vous Salue, Marie", de Godard, que faz um paralelo entre a história da mãe de Jesus e a de uma menina chamada Maria. A moça engravida, mas o filho, chamado Jesus, não é de seu namorado, José.

Se os cortes a "Roque Santeiro" haviam sido discretamente registrados na imprensa, a proibição do filme teve repercussão bombástica, com uma cobertura de tom fortemente crítico, fazendo definitivamente cair o manto do mito do fim da censura. Em um editorial com o título "Triste País", a "Folha" opinou que, com essa censura, "toda a farsa da Nova República cede lugar à violência contra o que é um direito elementar dos cidadãos". "Censurando o filme, o presidente Sarney conseguiu fazer a 'Nova República' pior -isto é, mais frágil, mais falsa, mais ridícula- do que sempre foi”,

\footnotetext{
${ }^{620}$ MARETTI, Eduardo. Em "épocas de trevas”, censura ressurge e volta a ameaçar o país. Rede Brasil Atual, 3/5/2016, disponível em http://www.redebrasilatual.com.br/cidadania/2016/05/em-epoca-detrevas-censura-volta-a-ameacar-o-pais-7049.html (acesso em 16/6/2016)

${ }^{621}$ KUSHNIR, Beatriz. Cães de Guarda - Jornalistas e censores do AI-5 à Constituição de 1988. São Paulo: Boitempo, 2004, p. 145

622 Ibidem, p. 144
} 
atacou o texto. "Humilhou os cidadãos, tratando-os como se fossem incapazes de decidir, por eles mesmos, o que devem ou não ver", completou ${ }^{623}$.

A decisão traumática de Sarney culminou com a saída de ministro Lyra, que havia se declarado favorável à liberação da obra. Ele foi substituído por Paulo Brossard, que assumiria uma postura mais conservadora. No calor da repercussão, Coriolano, também contrário à proibição do filme, concedeu entrevista à "Ilustrada" em que denunciou que o SNI controlava a DCDP624. Fazia mais de uma década que a censura de "Roque Santeiro" ocorrera após o SNI ter descoberto, por meio de grampo ilegal de um telefonema de Dias Gomes, a conexão entre a novela e a peça proibida "O Berço do Herói". Agora, com o desabafo de Coriolano à "Folha", essa conexão entre os dois aparelhos da ditadura tornava-se pública.

O SNI, aliás, ainda produziria documentação envolvendo o nome Dias Gomes até o ano da extinção do órgão, em 1990, no governo Collor. Após os oito informes gerados em 1985, haveria quatro em 1986, um em 1987, quatro em 1988 e um último em 1990. A temática seguia a mesmíssima da ditadura, como a ajuda do autor para produzir propaganda eleitoral do $\mathrm{PCB}^{625}$ e uma viagem a Cuba ${ }^{626}$. Curiosamente, em novembro de 1987, a inteligência registrou a publicação de reportagem da "Veja", "SNI: o retrato do monstro de cabeça oca", sobre a revelação do jornalista Ayrton Baffa, de "O Estado de S. Paulo", de arquivos produzidos pelo SNI na ditadura, entre eles o do grampo de "Roque Santeiro". O monstro de cabeça oca colocaria Dias Gomes pela última vez sob vigilância em 13 de fevereiro de 1990, pouco mais de um mês antes de ser extinto por Collor, ao relatar que o dramaturgo, "militante do PCB" e com “antecedentes negativos”, pedira autorização para viajar. Aos Estados Unidos ${ }^{627}$.

Outro monstro de cabeça oca, a Divisão de Censura, iria, entre 1985 e o início de 1987, cortar 261 letras de música e vetar outras 25 , fora as tesouradas frequentes às novelas, com uma equipe que ganharia novos quadros ainda em 1986, somando 220 técnicos ${ }^{628}$. Dias Gomes ainda enfrentaria dois episódios marcantes após "Roque

\footnotetext{
${ }^{623}$ Triste país. Folha de S.Paulo, 5/2/1986, p. 2 [editorial não assinado]

624 ÁLVARO, Marcia e GALVEZ, Virgínia. SNI controla Censura, diz Coriolano. Folha de S.Paulo, $11 / 2 / 1985$, p. 23

${ }^{625}$ Ministério do Exército, Gabinete do Ministro, Informe nº 087-S/102-A5-CIE, 24/2/1987

626 SNI, Agência Central, ACE nº 060789/87, 25/2/1987

${ }^{627}$ Ministério da Aeronáutica, Secretaria de Inteligência da Aeronáutica, Informe $n^{\circ}$ 023/90/220/AGINT -

RJ, 13/2/1990; a extinção do SNI foi determinada pela medida provisória no ${ }^{\circ} 150$, de 15/3/1990.

${ }^{628}$ KUSHNIR, Beatriz. Cães de Guarda - Jornalistas e censores do AI-5 à Constituição de 1988. São Paulo: Boitempo, 2004, p. 147
} 
Santeiro". A Censura ficaria de cabelo em pé com "Mandala", escrita por ele, em parceria com Marcílio Moraes, e exibida entre maio de 1987 e outubro de 1988. A novela era inspirada em "Édipo Rei”, de Sófocles, em que Édipo mata o pai e se casa com a mãe, Jocasta, sem saber que era filho deles (na TV, Édipo foi interpretado por Felipe Camargo e Jocasta, por Vera Fischer). A sinopse, quase vetada, só seria liberada com uma carta de Boni à Censura se comprometendo a não exibir o incesto. Ao longo dos capítulos, vários vetos ocorreriam, e Dias vivia perguntando a Boni, com seu velho tom irônico: “E aí, vou botar pra trepar ou não?”. E o chefe the respondia: "Vai levando por mais um tempo...". No fim, o casal chegou a dar um beijo, que foi vetado mas depois, com recurso, liberado ${ }^{629}$. Em abril de 1988, iria ao ar a adaptação de "O Pagador de Promessas", em formato de minissérie. No ano anterior, a sinopse da obra teve problemas com a DCDP e até com o Conselho Superior de Censura. O ministro Brossard considerou que a série apresentava "erotismo exacerbado". Durante a exibição, a censura foi interna, após pressão de patrocinadores para que o enredo sobre a reforma agrária, introduzido por Dias Gomes na versão televisiva, fosse suprimido. Mesmo com seus protestos, Roberto Marinho determinou o corte, passando de 12 para oito capítulos ${ }^{630}$.

O último parecer sobre "Roque Santeiro" analisou do capítulo 204 até o último, o 209 , todos liberados sem restrições ${ }^{631}$. Registrou que foram enviados à censura prévia dois finais para o Padre Albano e Tânia, sendo que em um deles os dois permaneciam juntos e no outro, ele a abandonava para ficar com a Igreja. Também duas gravações diferentes foram enviadas com o final de Roque Santeiro, que finalmente havia concordado em deixar a cidade. Em um deles, a Viúva Porcina decidia ficar com ele; no outro, com Sinhozinho Malta. Esses eram os dois principais desfechos aguardados pelo público (o primeiro havia reacendido o debate sobre o celibato e o segundo mostraria se quem vence no final é o bem/Roque ou o mal/Sinhozinho), e a gravação e o envio à Censura de duas versões serviam para evitar que o final fosse antecipado pela imprensa.

\footnotetext{
${ }^{629}$ Entrevista de Marcílio Moraes à autora; ele foi coautor de "Mandala".

${ }^{630}$ Para os problemas com a Censura Federal, SACRAMENTO, Igor Pinto. Nos tempos de Dias Gomes - A Trajetória de um intelectual comunista nas tramas comunicacionais, doutorado na UFRJ, 2012, p. 431-432; para a censura interna, GOMES, Dias. Apenas um subversivo. Rio de Janeiro: Bertrand Brasil, 1998, p. 341-342

${ }^{631}$ Ministério da Justiça, Departamento de Polícia Federal, Divisão de Censura de Diversões Públicas, Parecer $n^{\circ}$ 103/86, 14/2/1986
} 
Em 23 de fevereiro, a "unanimidade nacional" chegava ao fim. Albano decide não abandonar a luta pelos pobres na Igreja e deixa Tânia. Dividida entre a paixão por Sinhozinho e Roque, a Viúva Porcina, que transformara em moda no País os laços coloridos no cabelo e todo o visual extravagante, opta pela segurança da relação com o "coronel" da cidade, que tinha poder para mandar e desmandar, enquanto balançava a pulseira de ouro dizendo o bordão que acabou incorporado ao linguajar brasileiro: "Tô certo ou tô errado?"

A "Veja" relatou o final da novela sob o título "O milagre de 'Roque Santeiro', a novela de maior audiência de todos os tempos"632. A "Folha" acionou até uma pesquisa Datafolha para saber se os paulistanos haviam aprovado o final (56\% reprovaram) ${ }^{633}$, com um esquema de cobertura de final de Copa do Mundo para o último capítulo. Mandou até um repórter para tentar encontrar os outsiders que, à hora do encerramento de novela, ousaram assistir a um filme ou a uma peça de teatro ${ }^{634}$.

A novela proibida na ditadura terminava em clima de completa celebração. Era a novela da "Nova República" que chegava ao fim, e, assim como Roque Santeiro deixou a Asa Branca para que seu mito sobrevivesse, a censura sofrida pela novela em plena era democrática seria enterrada na memória, para deixar praticamente intacto o mito da liberdade de expressão. O primeiro livro a catalogar as novelas do País, "Telenovela Brasileira - Memória", escrito pelo jornalista e colunista de TV Ismael Fernandes, registraria que "Roque Santeiro" tornou-se "coqueluche nacional" quando "o Brasil se reuniu mais uma vez em frente à televisão para assistir à inteligente sátira nacional de Dias Gomes, censurada em 1975 e [que] só com os ares da Nova República pôde estrear e se exibir por inteiro [grifo nosso]. ${ }^{9635}$ Dias Gomes também só abordaria em sua autobiografia o "enorme sucesso, chegando alguns de seus capítulos a marcar $100 \%$ de audiência" ${ }^{636}$.

Como "Roque Santeiro", a "Nova República" foi sem nunca ter sido ${ }^{637}$.

632 O milagre de "Roque". Veja, ed. 912, 26/2/1986, p. 96-98 [matéria não assinada]

${ }^{633}$ Final de "Roque Santeiro" decepcionou. Folha de S.Paulo, 24/2/1986, p. 21 [matéria não assinada]

${ }^{634}$ Programa dos que não quiseram saber da telinha. Folha de S.Paulo, 23/2/1986, p. 81

${ }^{635}$ FERNANDES, Ismael. Telenovela brasileira. Memória. São Paulo: Brasiliense, $3^{\mathrm{a}}$ edição, 1994, p. 132; 309

${ }^{636}$ GOMES, Dias. “Apenas um subversivo". Rio de Janeiro: Bertrand Brasil, 1998, p. 224

${ }^{637}$ A frase é inspirada em trecho de artigo de Leão Serva na "Ilustrada": "Eu acho que a 'Nova República' é mais ou menos um 'Roque Santeiro', aquele que foi sem nunca ter sido”. SERVA, Leão. Baixou o Austral. Folha de S.Paulo, 1/3/1986, p. 41 
Seis meses após o fim de "Roque Santeiro", "Cobra", de Sylvester Stallone, foi censurado. Em agosto de 1986, sem assistir ao filme, o ministro Paulo Brossard, após cogitar o seu banimento completo do território nacional, subiu a classificação determinada por Coriolano, de 14 para 18 anos, e ainda pediu cortes em cenas violentas. Stallone, um ator declaradamente de direita, e seu personagem Cobra, detetive da mesma linha ideológica, também enfrentaram no Brasil outro tipo de resistência, conforme registrou a revista "Veja", na matéria "A esquerda da Censura": a de intelectuais. Entre eles, quem defendeu a proibição, por considerar o filme, que também não havia visto, "social e culturalmente nocivo", foi Dias Gomes ${ }^{638}$.

Afinal, a saga da censura não tem heróis perfeitos, em uma luta entre o bem e o mal. Ainda que o País precise acreditar nesse mito. 


\section{CONSIDERAÇÕES FINAIS}

Como a ditadura analisava, através do SNI, a presença de artistas de esquerda na televisão? O que os militares pensavam sobre a Globo, as telenovelas, Dias Gomes? Com que justificativas legais sua novela "Roque Santeiro" foi censurada em 1975, na véspera da lançamento, na Globo, e a peça que the dera origem, "O Berço do Herói”, proibida no dia do lançamento, em 1965 ? O que de fato estava por trás deste veto? Em 1985, quando a novela foi ao ar, aclamada como símbolo da Nova República, a censura realmente havia acabado? O que preocupava o governo e seus censores em cada um desses três momentos, que coincidem com o início, o meio e o fim do regime militar? Como se dava a relação entre um célebre comunista, a maior emissora de televisão do País e o Estado ditatorial?

Essas são algumas das perguntas que este trabalho pôde responder, a partir de um corpus reunido em 2011, durante um período sabático que tirei na "Folha de S.Paulo". São cerca de duas mil páginas de documentos oficiais, a maioria com carimbos de "secreto" ou "confidencial" e agora revelados pela primeira vez, além de cartas pessoais de Dias Gomes e de um diário inédito, de valor inestimável, em que o autor explica o processo de criação de "O Pagador de Promessas" e no qual confessa seus dramas para conciliar seu ideário político e a carreira artística, sempre num pêndulo entre a autenticidade dos palcos e as grandes plateias da televisão. A documentação foi costurada por entrevistas com Boni, Ferreira Gullar, Lauro César Muniz, Marcílio Moraes e diversos outros profissionais que tiveram contato com Dias Gomes, além de seu filho, Alfredo Dias Gomes, e da viúva, Bernadeth Lyzio -que possibilitou o acesso à documentação do escritor no SNI e a seu acervo particular, no qual estão o diário e as cartas.

Quando ingressei no mestrado, em 2014, com todo o material já coletado, o desafio foi transformar esse caldo de informações em um objeto de pesquisa. E ele se edificou aos poucos, até ficar claro: a força simbólica que tem "Roque Santeiro", em seus três momentos -a peça de 1965, a novela censurada de 1975 e a exibida em 1985-, para desvendar um período crucial da história do País.

Difícil imaginar um produto midiático com tamanha capacidade. Que outra obra "conseguiu" o feito de ser inteiramente censurada como novela de TV e peça de teatro, além de um roteiro para cinema que os censores nem quiseram receber? Que outra obra 
foi considerada simbólica da repressão militar à cultura e da volta da liberdade de expressão no final da ditadura - enquanto acumulava mais de 500 páginas na Divisão de Censura de Diversões Públicas? Que outra obra, com todo esse histórico, chegou a atingir $100 \%$ de audiência na televisão brasileira?

É uma saga ímpar na luta contra a censura.

Diante de um corpus riquíssimo como esse, constituído em grande parte por fontes primárias, o desafio foi sistematizá-lo para o campo da Comunicação. Seria preciso escolher um caminho metodológico que pudesse conciliar a quantidade de informações levantadas à exigência da precisão acadêmica e ao DNA jornalístico deste trabalho. Afinal, se estamos na Escola de Comunicações e Artes, que forma jornalistas (e foi onde eu realizei a minha graduação), por que as ferramentas do jornalis mo não poderiam auxiliar a pesquisa, desde a coleta de dados até a redação da dissertação?

Sem dúvida, meus 20 anos de atuação como jornalista foram importantes no levantamento desse corpus, na busca pela documentação, nas entrevistas. São métodos de abordagem que favorecem o acesso à informação e que me ajudaram, por exemplo, a chegar ao diário do escritor e às entrevistas. Para a dissertação, trilha semelhante de conciliação entre a academia e o jornalismo começou a soar possível quando, em uma aula de Metodologia da Pesquisa em Comunicação, na ECA, a professora Maria Immacolata Vassallo de Lopes ensinou: “É preciso deixar o objeto falar”. Sim, se o objeto é tão forte, vamos a ele do primeiro ao último capítulo.

"Roque Santeiro" traçou a rota.

Sendo essa uma das novelas mais importantes da televisão brasileira, acompanhar sua trajetória foi a chave para seguir no campo da Comunicação. Ainda que a História e a Sociologia tenham sido guias importantes, o que se comprova é a força de um produto midiático como revelador de um período importante do País. Não é contada aqui a história do Brasil entre 1965 e 1985. Mas, sim, é narrada como a saga de "Roque Santeiro", por trás das telas, revela aspectos de sua época.

Explorar os três momentos da obra -a peça e as duas versões da novela-, que chamei de três "atos" na dissertação, possibilitou demonstrar maneiras distintas de atuação da Censura governamental, o que deverá contribuir para outros estudos sobre a repressão à cultura, especialmente na área da Comunicação. Para isso, foi demonstrado como se construiu o aparato legal que justificou as proibições, desde o início da República. 
No primeiro ato, temos o veto a "O Berço do Herói”, em 1965, com o qual foi possível observar como o teatro, naquele momento, era o foco da Censura, que ainda se encontrava descentralizada nos Estados -a proibição partiu do governador Carlos Lacerda- enquanto o aparelho da ditadura militar era organizado em Brasilia. Também esse episódio ilustra de que maneira a censura tornou-se um "tiro no pé" para o regime, pois logo no primeiro momento conseguiu unir a esquerda aos liberais, que em parte haviam apoiado o golpe de 1964, em torno da defesa da liberdade de expressão.

Depois, no segundo ato, deu-se a análise da famosa proibição de "Roque Santeiro", na véspera da estreia, em 1975, quando a TV, em razão de seu enorme alcance, tornara-se a principal preocupação dos censores. $\mathrm{O}$ veto à novela ficou na memória como simbólico da repressão naquele período. Mas deve ser visto, na verdade, como uma ruptura do que era comum à época: a frequente e tensa negociação entre emissoras de TV e censores, em que os cortes eram negociados, evitando-se decisões mais trágicas, a exemplo do cancelamento a novela. Ele se deu em um ano peculiar da história da ditadura, quando o discurso de abertura de Geisel escondia um descontrole do aparelho repressivo -dois meses após a censura à novela, Herzog foi assassinado. Dessa forma, ao buscar o que estava por trás do editorial lido por Cid Moreira em 27 de agosto de 1975 no "Jornal Nacional", denunciando a censura a "Roque Santeiro", o que se encontra é a história da crise do regime militar, que, após o aniquilamento da luta armada, tentava justificar a manutenção de sua estrutura repressiva.

A documentação da Divisão de Censura de Diversões Públicas (DCDP) de "Roque Santeiro" de 1975 revela o passo-a-passo burocrático que culminou com a proibição. Deixa claro que o departamento não tinha base para o veto, reforçando a ideia de que a decisão foi consequência do grampo ilegal, feito pelo governo, de uma conversa em que Dias Gomes contou ao amigo Nelson Werneck Sodré que a novela era baseada na peça censurada em 1965. As reportagens da época mostram que o episódio transformou a censura em um debate nacional, extrapolando as rodas intelectuais.

Provavelmente uma das principais contribuições desta pesquisa seja a avaliação, no terceiro ato, do que se deu durante a exibição da nova versão da novela, em 1985. O que temos na memória do País é uma festa "unânime", com elogios da crítica à "novela da Nova República" e números impressionantes no Ibope, laços coloridos da Viúva Porcina tornando-se moda no Brasil e o bordão "Tô certo ou tô errado?", de Sinhozinho, entrando no linguajar nacional. O que esse clima festivo ocultou foram as 597 páginas 
que a Divisão de Censura de Diversões Públicas reuniu sobre a novela. O calhamaço, conforme foi demonstrado neste trabalho, denuncia que mais da metade dos 209 capítulos sofreram seguidos cortes. A análise desse material, com o cruzamento das reportagens da época e das entrevistas feitas para esta pesquisa, jogam luz nos obstáculos do período de redemocratização, no qual a máquina ditatorial não se desmontou, foi apenas se transformando "camaleonicamente", muitas vezes amparada por parte da sociedade favorável a um controle da produção cultural.

Os papéis da DCDP referentes à versão de "Roque Santeiro" de 1985 apresentam farto material relativo à negociação entre o governo e as emissoras, com a Globo recorrendo de vetos específicos, às vezes escrevendo para pedir a liberação de uma cena ou até uma única frase, e a Censura determinando, em tom de ameaça, o que a novela não poderia exibir -personagens homossexuais e adultério, por exemplo. A cobertura dos jornais da época ilustra como a imprensa embarcou no discurso da volta da liberdade de expressão da Nova República, ainda que importantes registros tenham sido feitos por algumas reportagens e artigos sobre a censura aos capítulos de "Roque Santeiro" (o que obrigou o governo a liberar sem cortes a segunda metade da novela).

As aulas do curso de Comunicação, Censura e Liberdade de Expressão Desafios da Atualidade, ministrado por Maria Cristina Castilho Costa, na ECA, com o auxilio de rica bibliografia, possibilitaram uma abordagem da censura em sua complexidade. Forneceram instrumentos para analisar a extensa documentação da Divisão de Censuras e Diversões Públicas levantada no Arquivo Nacional, sempre a buscar o que estava por trás dos rabiscos dos censores e a cruzar os vetos com os temas que mobilizavam o poder em cada um dos três momentos abordados.

A base conceitual obtida no mestrado tornou-se essencial para que a dissertação lembrasse sempre que a censura não estava limitada ao que ficara guardado nos registros oficiais. Ela envolvia -e sempre envolve, aliás- relações multifacetadas entre diversos setores da sociedade, os quais muitas vezes não só concordam com a repressão como a exigem. A saga de "Roque Santeiro" demonstra que, mesmo quando o Estado detinha o poder censório, o cerceamento não se limitava à sua caneta. Coexistia com a vertente "judicialista" da censura, tendo os júzes como censores, e com uma das mais poderosas, a econômica, no qual o controle é exercido por anunciantes ou mesmo pela própria televisão. Para abordar a autocensura, entre diversos documentos que foram aqui apresentados, temos a interessante carta enviada por Dias Gomes a Boni, onde o 
dramaturgo diz temer que o clima do País estivesse levando "cada funcionário da Globo, desde os mais escalonados aos mais humildes, a se transformarem num censor". Como foi dito, os três atos de "Roque Santeiro" comprovam que a censura "é ampla, geral e irrestrita". Observar seus outros tentáculos, para além do Estado, atuantes mesmo durante a ditadura, é fundamental para se entender a censura na atualidade, quando vivemos em um período democrático, onde está pressuposta a liberdade de expressão. Somam-se a isso as considerações a respeito da distinção entre a censura política e a censura "moral e dos bons costumes". Esta última, como foi visto, persiste mais facilmente em períodos democráticos, e é a base da Classificação Indicativa, que substituiu a censura a partir da Constituição de 1988. Amparada por parte da sociedade, o cerceamento moral esconde um viés político, do controle da produção simbólica.

A documentação do SNI sobre Dias Gomes se revelou um material valioso para o estudo da Comunicação, como potencial a ser investigado sob outros ângulos. Temos ali detalhes de como a inteligência do governo analisava a "infiltração da esquerda" na televisão, o poder político desse veículo e especialmente das telenovelas. Se, por um lado, elas foram importantes no projeto de unificação nacional pretendido pelo regime militar, por outro, tornaram-se veículos de "subversão", na análise dos militares. Até Janete Clair, acusada por setores da esquerda de "alienada" politicamente, pelo tom melodramático de suas histórias, era considerada perigosa pelo SNI (essa aparente contradição, aliás, poderia ser objeto de uma pesquisa específica). As 432 páginas produzidas pela inteligência militar em que Dias Gomes é mencionado auxiliaram na reconstituição de como a indústria cultural se apropriou da arte de esquerda a partir dos anos 1970, sendo o caso do dramaturgo exemplar desse processo.

O diário de Dias Gomes é provavelmente o documento de maior valor desta pesquisa. Em um primeiro momento, pode soar desconectado do objeto, pois as anotações começam em 1959 e terminam em 1962, ano anterior ao da criação de "O Berço do Herói”. O caderno brochura abarca, no entanto, um período fundamental para se compreender a obra de Dias Gomes: a elaboração de "O Pagador de Promessas", que se tornaria a base de sua dramaturgia, além de um marco para a cultura brasileira. Dessa forma, foi um privilégio demonstrar a gênese do objeto deste estudo através de um documento inédito e histórico. Ao observar o processo de criação de "O Pagador de Promessas" e, na sequência, de "A Invasão", que ele também escreve nesse período, compreende-se como chegaria a "O Berço do Herói” e a toda a sua obra posterior. 
Apesar da relevância desse documento, ele é mote de apenas um capítulo, o segundo, porque, de outra forma, haveria o risco de um desvio do objeto da pesquisa. Além disso, o olhar sobre as anotações de Dias Gomes se concentrou em prismas que se relacionam com a saga de "Roque Santeiro". Nesse contexto, o documento não foi estudado em sua totalidade, mas de forma parcial, que auxiliasse a desnudar o objeto. Espero que este seja apenas um primeiro contato com as anotações de tamanha relevância feitas por Dias Gomes. O diário é, em si, um rico objeto de pesquisa, e merece ser destrinchado em cada uma de suas 78 páginas, 6.561 palavras, nas quais se observam passagens da história do teatro, do rádio, da televisão, da arte de esquerda, enfim, da cultura nacional, para não dizer do Brasil. Isso sem falar das questões pessoais de uma biografia das mais interessantes do País.

E, por falar em biografia, considero que, de algum modo, esta dissertação possa ser caracterizada como uma "biografia de 'Roque Santeiro"'. Esse, aliás, era o projeto inicial, quando teve início a coleta de informações no período sabático: escrever um livro-reportagem com a biografia da novela. Não obstante a escolha do caminho acadêmico, creio ter chegado a esse mesmo fim. E penso que esse seja um modelo a ser explorado com outros produtos culturais, através dos quais é possível mergulhar na história do Brasil. A biografia de uma peça, um filme, uma música, uma poesia. Certamente são muitas as obras com ricas histórias a serem contadas.

A opção foi narrar os episódios cronologicamente, na maior parte da dissertação, a fim de levar o leitor a acompanhar a evolução dos acontecimentos. A narrativa vai encaixando as peças do corpus levantado, documentos do SNI, da Censura, jornais da época e entrevistas atuais que resgatam os períodos retratados, entremeando com análises da bibliografia de apoio. Assim, a biografia de "Roque Santeiro" começa em 1953, quando Dias Gomes é demitido da Rádio Clube em consequência da denúncia feita por Carlos Lacerda, em sua "Tribuna da Imprensa", de que o escritor havia viajado a Moscou a fim de colocar flores no túmulo de Stálin. Segue pelos anos do diário, entre 1959 e 1962, passando pelo fatídico 1964 até chegar à censura a “O Berço do Herói’, em 1965, pelo mesmo Carlos Lacerda, nesse momento governador do Rio.

A entrada de Dias Gomes, na Globo, em 1969, exigiu uma digressão, voltando à inauguração da TV no Brasil, em 1950, chamada de "veículo subversivo" por Chateaubriand. E assim foi possível contar um pouco da história da televisão, de seu crescimento em audiência e em poder político, do projeto militar para unificar o País 
através desse veículo e da controversa participação da esquerda na construção da teledramaturgia nacional. Protagonista desse movimento, Dias Gomes forneceu o itinerário da narrativa. Até chegar ao veto a "Roque Santeiro" em 1975, acompanha-se o início do dramaturgo na emissora, sempre monitorado pelo SNI, desde a primeira novela, que assinou sob pseudônimo de Stela Calderón porque era uma história herdada da antiga diretora de teledramaturgia, a cubana Gloria Magadan, aquela que achava que o Brasil não servia de cenário a novelas e que heróis não podiam se chamar João da Silva. Assim, este trabalho reconta como, a partir de Dias Gomes e de outros autores ligados à esquerda, "João da Silva" tornou-se protagonista da teledramaturgia, abençoado pelo projeto da ditadura militar de unificação nacional via TV.

Entre a censura a "Roque Santeiro" em 1975 e a exibição da nova versão da novela em 1985, dá-se a derrocada do regime militar, com muitas idas e vindas no caminho da volta à democracia. A saga do falso herói de Dias Gomes convida a observar, na realidade do País, inúmeras passagens em que o discurso do poder se distanciou da prática, com a abertura soando um mito. E a veiculação de "Roque Santeiro" no ano da democratização comprovou-se simbólica de como, muitas vezes, é difícil romper com o mito. Como seria possível acreditar que a novela da Nova República, que simbolizava a volta da liberdade de expressão, era censurada rotineiramente pela máquina repressiva da ditadura, que seguia intocada? Se Asa Branca não admitia que seu herói não morrera para salvar a cidade, o Brasil preferia não ver que a Nova República, como disse Dias Gomes, era uma velha com plástica.

Para a redação desta dissertação, a opção foi fazer uso do ritmo da linguagem jornalística, com o cuidado para que essa escolha não acarretasse em imprecisões acadêmicas, procurando sempre detalhar as informações e suas fontes (com o apoio, por exemplo, de 638 notas de rodapé). A coleção de cinco livros de Elio Gaspari sobre a ditadura militar brasileira, que forneceu dados e análises imprescindíveis à esta pesquisa, serviu ainda de referência nessa tentativa da somar jornalismo e exatidão. Claro que ambos deveriam idealmente andar sempre juntos, mas há certamente um grau de detalhamento que a produção jornalística muitas vezes não comporta, com suas limitações de tempo para apuração e avaliação dos fatos, e de espaço para a divulgação dos conteúdos. Se aqui fiz um esforço a fim de trazer do jornalismo um texto claro sem ferir as exigências acadêmicas, certamente saio dessa experiência com um novo patamar na busca pela precisão do trabalho jornalístico. 
6. APÊNDICES 


\title{
6.1. Relação de entrevistados
}

\author{
Alfredo Dias Gomes \\ Álvaro Moya \\ Bárbara Bruno \\ Bernadeth Lyzio \\ Boni (José Bonifácio de Oliveira Sobrinho) \\ Cid Moreira \\ Cláudia Raia \\ Clóvis Bueno \\ Emiliano Queiroz \\ Ferreira Gullar \\ Glória Perez \\ Henrique Veltman \\ Joaquim Assis \\ Jorge Adib \\ Lauro César Muniz \\ Lucinha Lins \\ Marcílio Moraes \\ Nelson Motta \\ Sebastião Vasconcelos \\ Tereza Rachel
}




\subsection{Imagens}

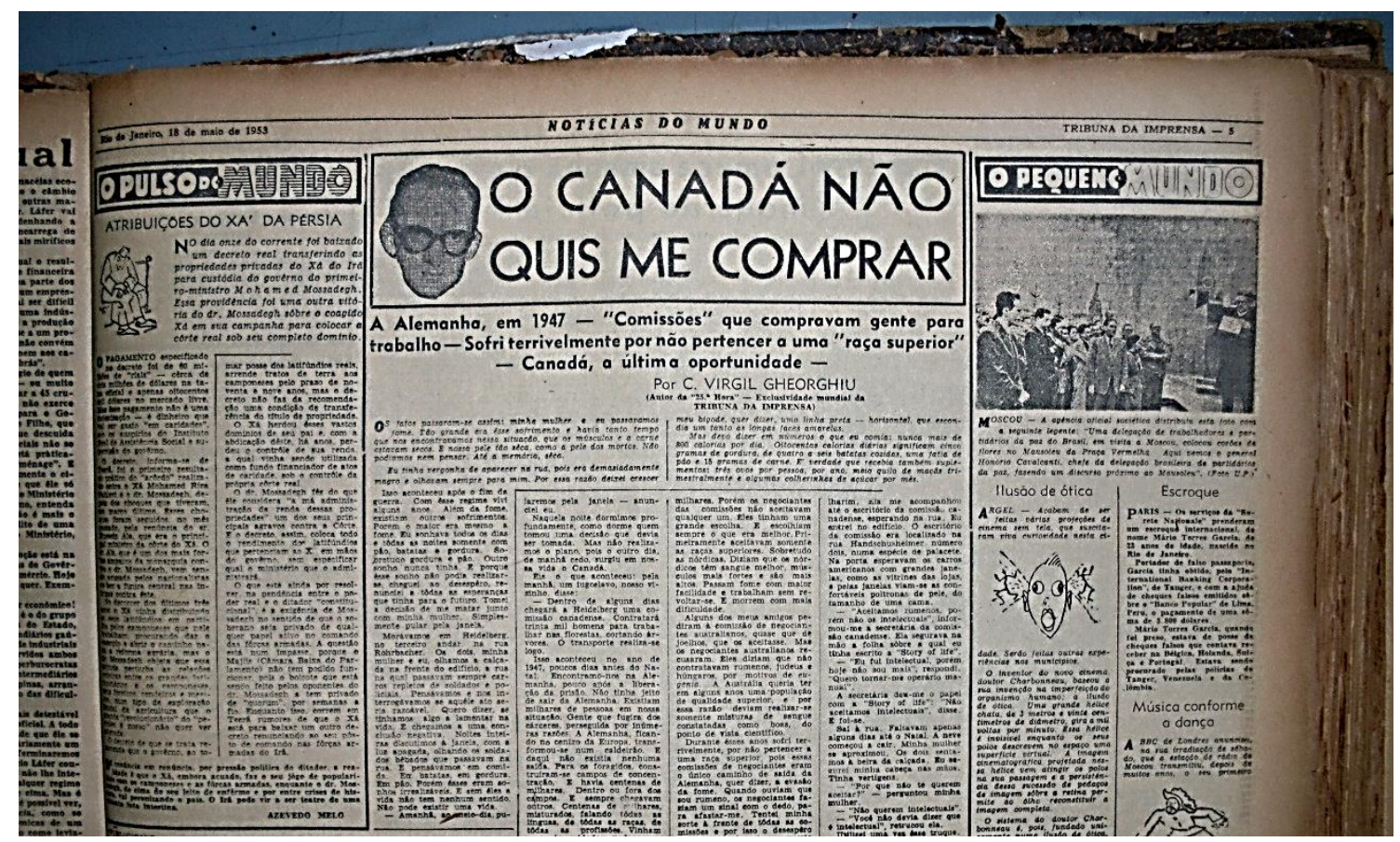

Em 18/5/1953, comitiva de Dias Gomes (foto), em visita a Moscou, é chamada de 'delegação de trabalhadores partidários da paz', na pág. 5 da 'Tribuna da Imprensa'

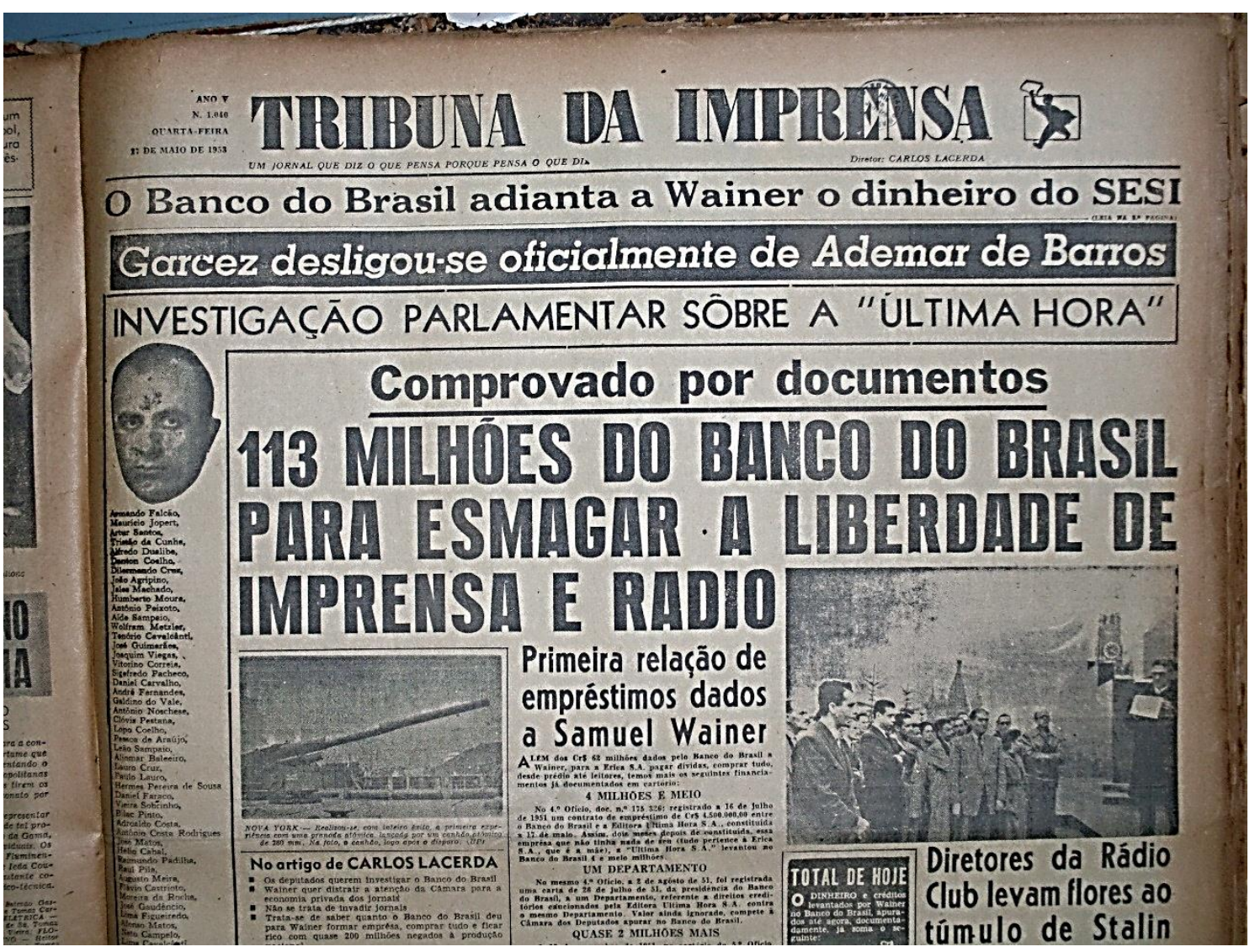

Após 9 dias, Carlos Lacerda republica a foto na $1^{\circ}$ página e a insere na guerra contra Samuel Wainer, que acaba demitindo Dias Gomes, seu funcionário na Rádio Clube 
284

de "Rafael" no final. Este personage, "Rufall mas stá sear. he gatedido ger algnas ceganherio do Pantido sen sectanirmo ( gueled decusher gre 2 -bore tage no Payido cominits sectanios gates crmante os jesios be inlemcismadan e eficieter, agresar de Undu, aposan de stare enado oser, métodn) sen sectairsmo; achm" ene comfambiran; o lorma antipitici e bera a plutía a codenir que

tuden on compitu sor ani-. Mra estan de acordo... \& puted -aten - perponag.

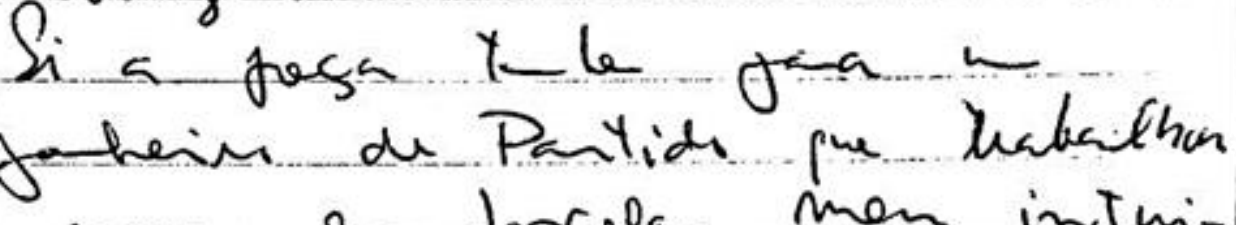
12 an a ferular men intuito ere o de verifiem a an. lenticidade dos men personagems 1 -dan dituagoer. 6 c-jambeico viluon w a jeca e nentum regano py.

Hoje, borei a peça gana fiani Rato les.

No diário, Dias narra resistência no PCB a personagem comunista de 'A Invasão' 


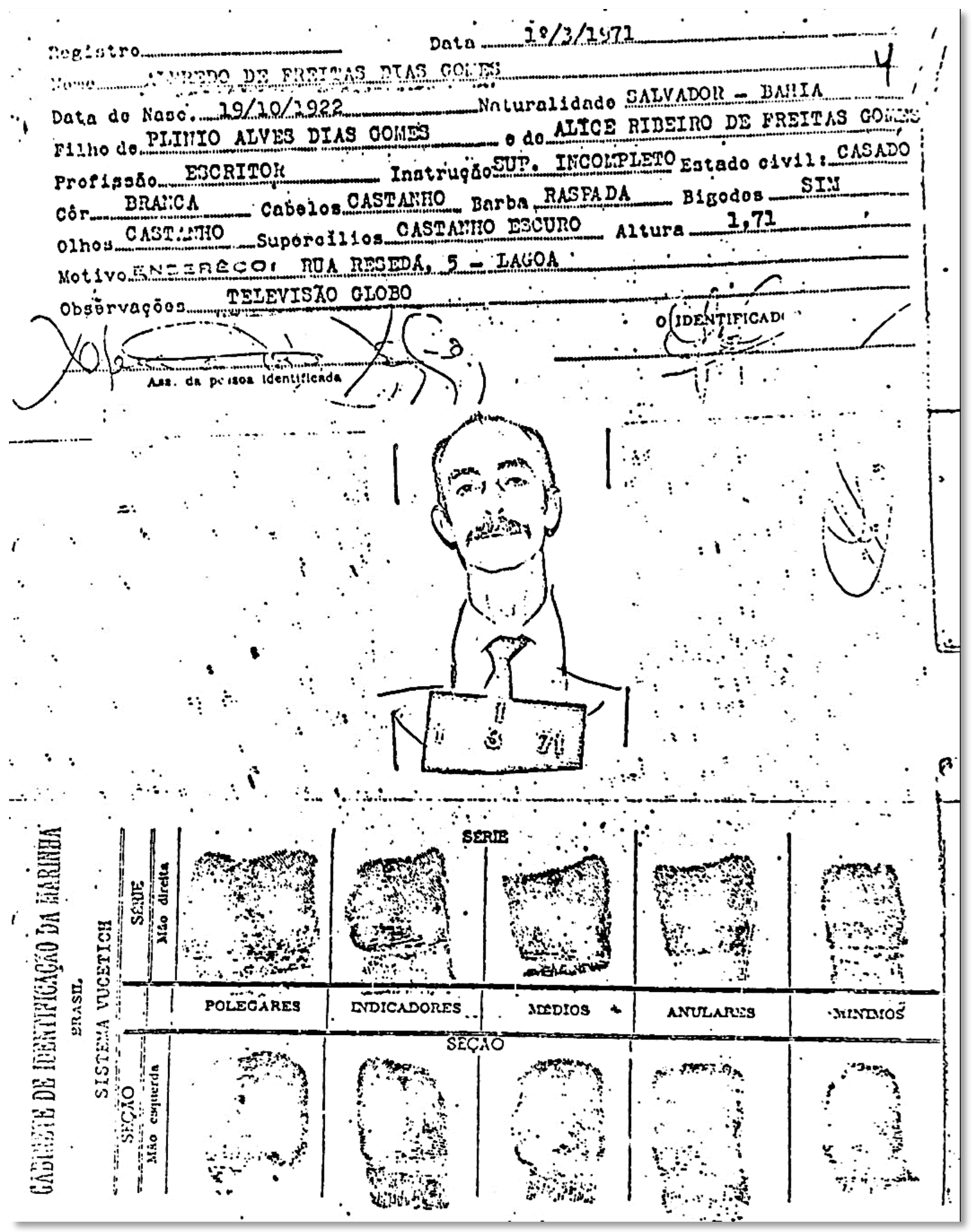

Ficha de depoimento de Dias, em 1971; antes do interrogatório, militar perguntou ao autor quem era o assassino de sua novela; sua resposta: 'Não revelo nem sob tortura' 


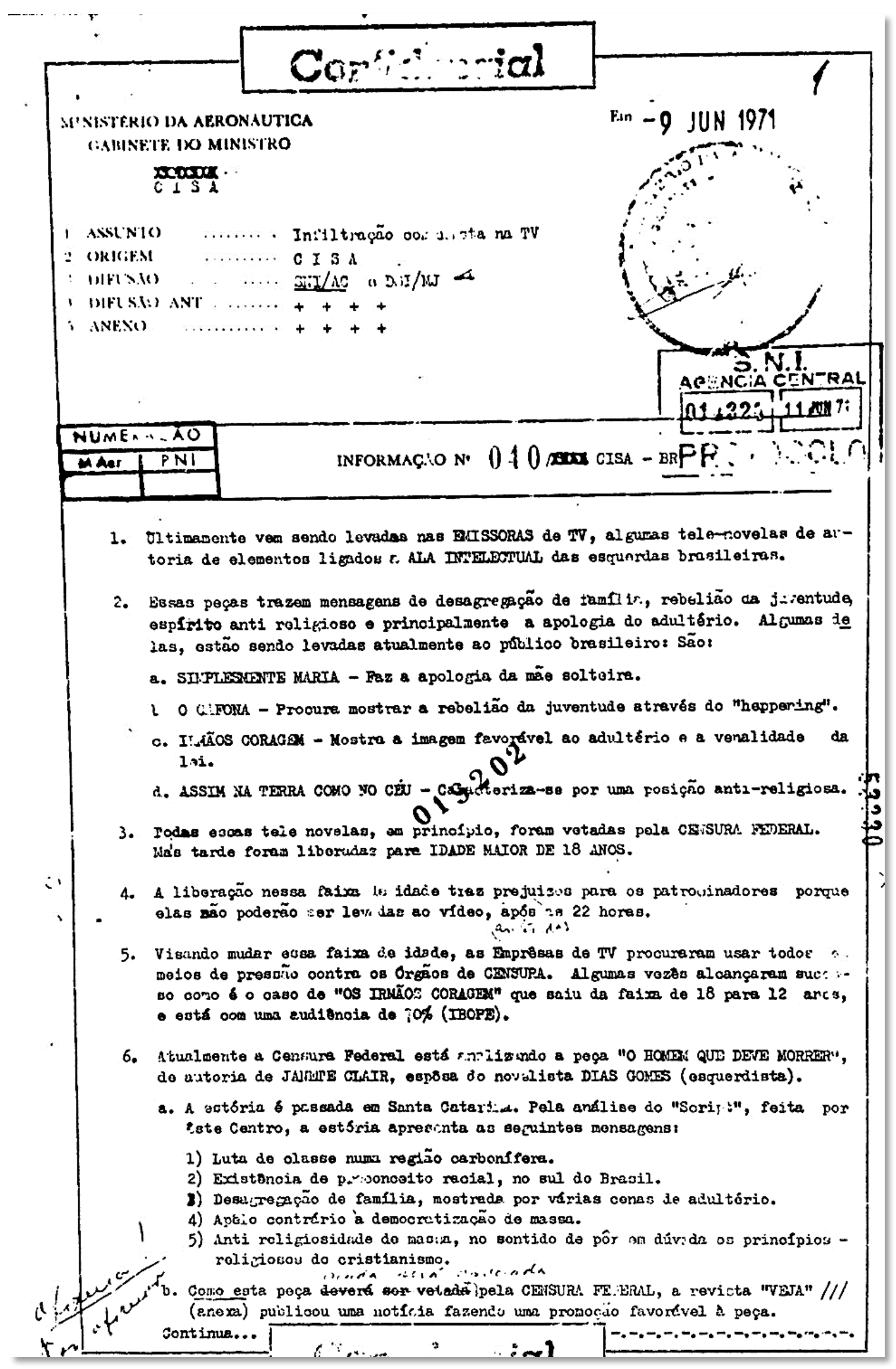

Informe enviado ao SNI sobre a infiltração comunista na TV e o perigo das novelas 
MIPISTEALO OA JUSTIÇA

DEPARTAMENTO DE. POLICIA FEDERAL

DIVISÁO DE CENSURA DE'DIVERTOES FÚBLICAS

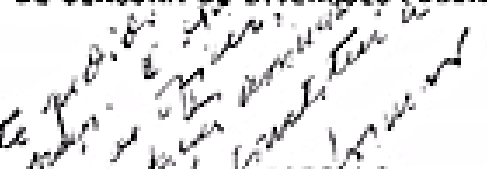

FIC HADO

8. A. DCDP

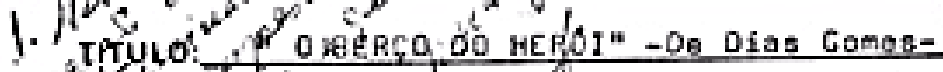

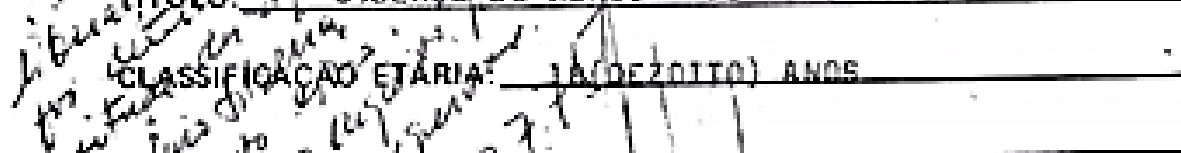

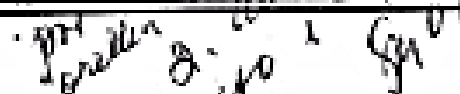

PECAGqpataviada do aspectoslidaológicos mas contundento

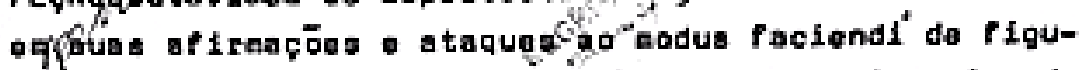
ras constelaradas possuidoras de valoras morals acina da mídia dos seus compatriotas...t una paça ofoita a caren to do astudo coaranto o, principalmonte, patríálca, pge ra beclarecer ou dosanuviar possfvala dúvidas qua certa menta oduiräo o todos que venham toma conhecieanto de/ ratos aemelhentos. O erro ó possíval o toda ser hunano, a quelquer povo, moa näo í admiagivel que tle se porpetua consolantemente, coso efolto to argulho ou da vaide da ou da leucura do poder, do donínio....Se hí erro, qua sojo soluetionado como tol, porqua a p-átrito ó á digno/ dos cous filhoe, so so pundamanta ne vardada, na hanra, no espirito de liberdade o raspeito oos volores indelévais da virtuda, que digniflce a homem e imortaliza ua povo, diante de Deus o do congenso das naçöa.

E aultos vazos irravarente, tendanoioso o prosélito.sua menaggen oxigo pletéia oselurecido, ovitando essim datur paçöas - ganeralizaçöes Stu erro Ć crier nos manos escla rocides a dúvida abre ós depale vultos de nosso história, - agredir os allitioras da Ravolução, cosa se _eneon tro ma orelbas da Livro.

Rolate O ORAMA do procinha da FEB -CABO JORGE-tido como harói a, poeteriormante, surgindo ä̌ e solve, louca do osudados do aur tarro * de gue gante. Mas a valdade do seus - I Insonidedo dos usurpaderes doram-1he morto soatroge num bordel, preparade priament, cavordemento.

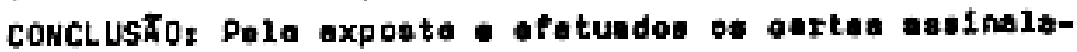
doo nas píginas $7,35,52,65,73,62,132,134,149,161,162$. 163, por farliow ad norme censórlas vigenties, móxime as

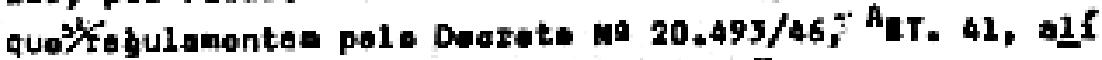

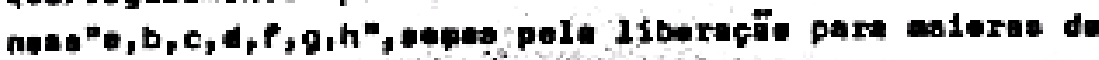

Relatório sobre 'O Berço do Herói' feito às vésperas do veto a 'Roque Santeiro'é indício de que o governo sabia que a novela era uma versão da peça censurada 


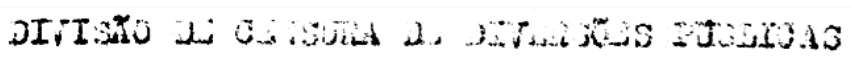

3rasilia, 04 do julino do 1975

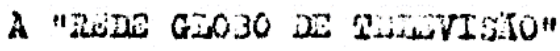

记 $2 \underline{2} \underline{\underline{A}}$

Irozados senhores:

is

Conunico a Vs. Sa. qूue 0 textos dos capituros de

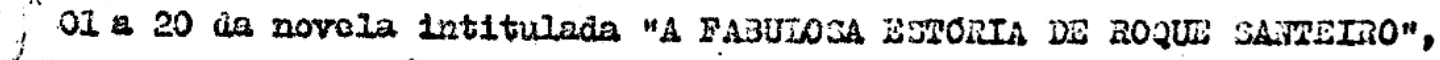
fte Dias Coines, foram aprovados para apresentagão apds as 20,00 horas, condicionados, no entanto, A rexificagão das Eravagõos, para obteng̨öo di cortificado liberatorio.

2. Hos teztos ostå asainaladas as passagens que aevem sir suprimidas, levando om conta o hordrio das apresentagöes, como

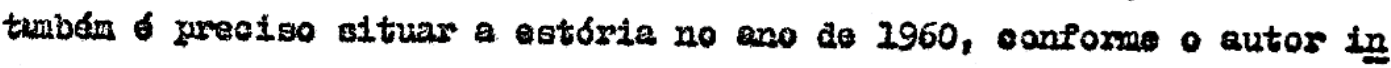
dea na sinopse, posto que constam oitações de fatos recontes, como porerônolas a Jacqueline Onassis, Prograna silvio santos, Jornal iraolo 1. 2al, ate., desaonhecidos na indieada bpoos.

4. 3. Nerecen ospocial outando da diregão as conas en que TINO - ITHDA as encontram deitados (oap. 4-pag. 07 - 08), bon como *a dos belfos entro ROBERTO LINDA, asedetidas pelo maxido (oap. 07 pas. 06-07 08).

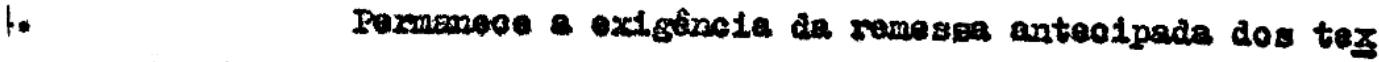
to: dos capffulos mbsequantes a a produgäo devie ouldar do manter 08 caluntos no memo nivel apresentado at acoxa, posto qua, ocorrenco

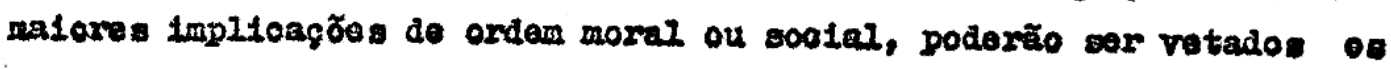
outros capitulos ou mudado o hordrio da novela.

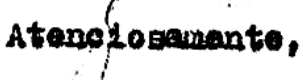

RÓGERTO IUUSS

Dirotor da DeDP

Em julho de 1975, diretor da Censura aprova 'Roque Santeiro'para as 20h, desde que feitos os cortes apontados e apresentadas as gravações dos 20 primeiros capítulos 


\section{SERVICOO PÚBLICO FEDERAL}

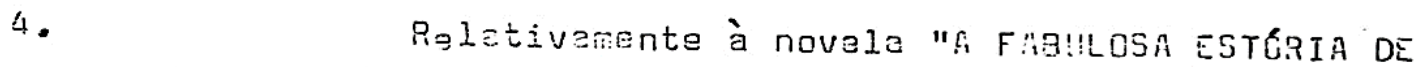
ROAUE SANTEIRO", cujos dez or:meiros capítulos gravados foram liberados para apresanteções após as 22,00 horas, dá para notar, já no seu início - normalmente suavizado pela produção pera obter classificeção etária baixa - que será conduzida/ numa atmosfera fortemente acsntuada de movimentação dramática! a psicológica, tornanco sua transmissão inedaquada pare o telespectador juvenil, euer polo impacto de cenes e dićlogos, quar oela mensagem, quer pelo orau do jnfluência dos personagens, dentre estes aparecenco revoltados, prostitutas, adúlteros,levianos, aproveitadores, fanáticos, etco

5. A forte temática - negativa sobre todas os as pactos - poderá conduzir a uma situação intolerável para omeio de comunicação a cue se destina, o que somente revelará o exame da gravação dos cepitulos subsecuentes. Isto ocorienco, a novela será, inevitavelments, proibida, ficando desda já a crị tério dessa empresa assumir o risco de ver interrompida, a qual cuer tempo, a transmiss̃̃o do programa, visto que a Divisão de Censura de Diversões públicas tem inistruções no sentido de não mais tolerar, como o faz com a novela "GABRIELA", as cenas a / situações que agridan os padrões normais da vida no lar e na sociedade ou que possam ferir, por quelcuer forme, a dignidade ou o interesse nacional.

Atenciosements

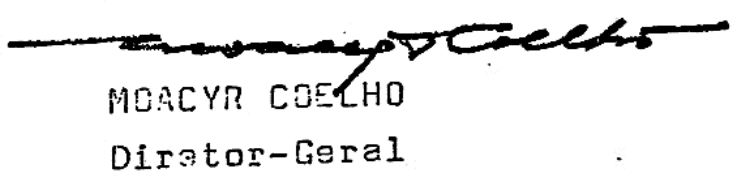

Em 27/8/1975, véspera da data da estreia, diretor da Polícia Federal determina o horário das $22 \mathrm{~h}$ e ameaça proibição; com 36 capítulos gravados, novela é cancelada 


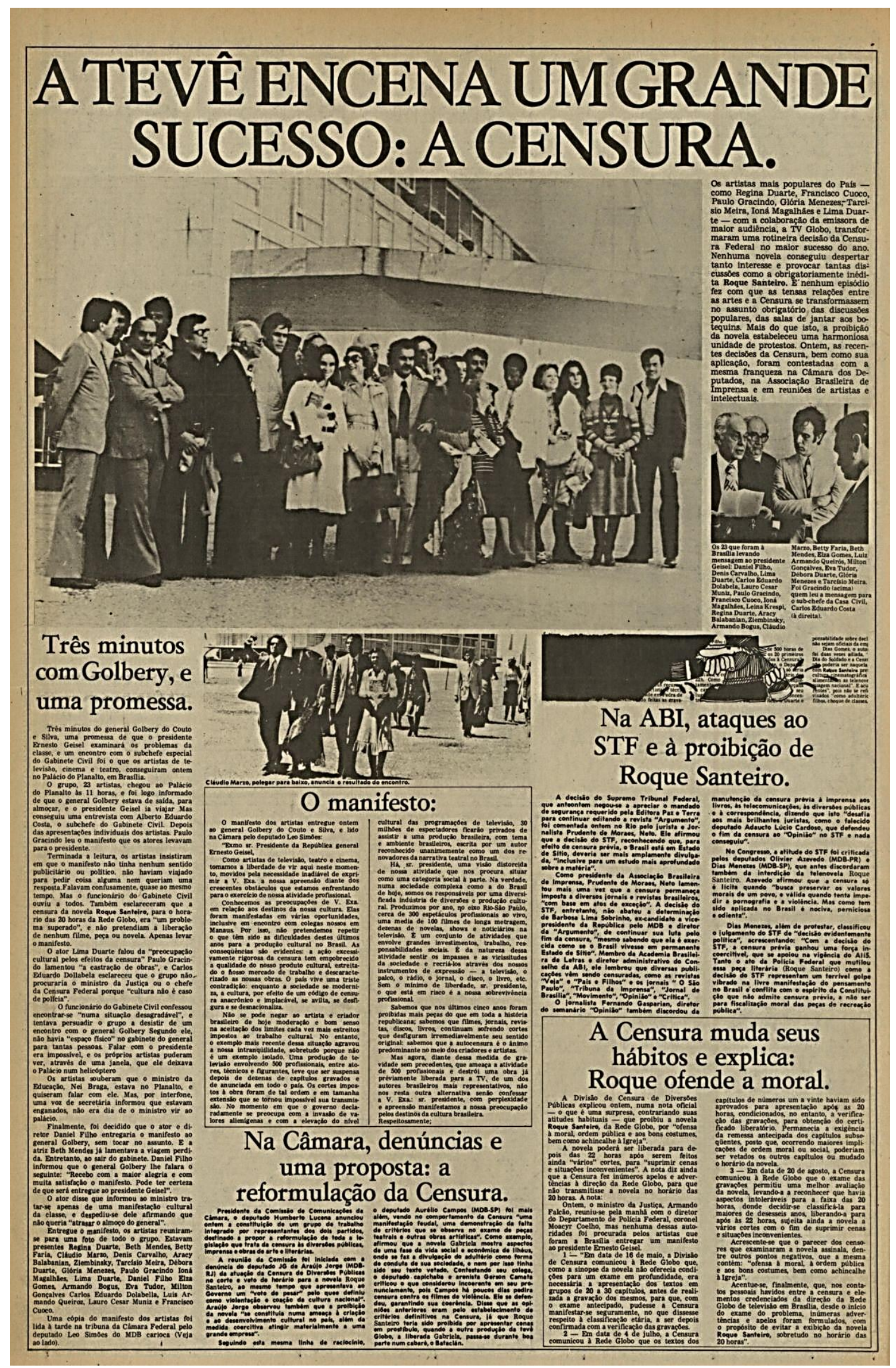

'JT' mostra globais em protesto no Planalto; censura à novela vira assunto nacional 


\title{
CONFIDENCIAL
}

\author{
complexe olobe
}

1. As empresas relacionadas abaixo Integram o Comploxo Globo, .w Isdo de ouiras, elnda desconhec1das, cujo levantamento esta lgônela solleltou à DSI/MIC, no vês que passou, o aln da nāo recobldo:

- Rádio Globo S.A.

- Rádio mundial S.A.

- Rádio EIdorado S.A.

- TV Globo.

- Jornal o Globo.

- Rio Gráflca Editora Ltda (Infão 215/72/ARJ/SNI/72)

- Som L1vre/Globo

2. A seguir, relactonam-se os nomes que so sabem integrar os quadros de cada empresa, seguldos da especificação da run. fão ocupada, quando conhec1da, - de un l1geiro comentár1o, consequente de análise de prontuário.

Os artictas que trabalham ou trabalharam para a organiza-çäo foram apenas c1tados, deste que o tempo disponfrel para epreciaçäo Individual '́ Insurfelente e eles não exercem runçāo de mando.

a. IV Giobo

1) Produzer trabalhos para a TV, sem Integrá-la:

a) GIANFRANCESCO GUARNIERI

Produz para a TV Olobo (Caso3 Espec1a1s)

F1lo-comunista. Ator. Poeta. S1gnatár1o de manifes tos de carátor polftico. Seus trabalhos são vef́culo de "conscleat1zaçäo" o protesto.

b) DIAS GOMPS

Produz novelas rara a TV Globo (núcleo das 2000 hs), a últime delas, Roque Santeiro, proibida fela Censy ra, recentemente. Comunista notór1o e confesso, com longo prontuár1o na ARJ. Domitido pelo AI-I da Rá-d10 Nacional. Integra a Base dos Artistas, que a--pola o PCB, segundo depoimento de Marco Antônto Tavares Coelho.

Relatório do SNI uma semana após o veto a 'Roque Santeiro'lista funcionários da Globo; outro seria feito após 3 meses, e o governo exigiria a demissão de Dias Gomes 
Las obras de V. I. Lenin y los libros que hablan de la vida y actividad del jefe del proletariado internacional provocan un enorme interés en todo el mundo. Según. datos de la U.N.E.S.C.O., los trabajos de V. I. Lenin ocupan el primer puesto en el mundo entre la literatura traducida.

V/O "Mezhdunaródnàya Kniga". la casa soviética para el comercio de libros mayor del mundo. le puede ofrecer a Ud. una gran variedad de trabajos de V. I. Lenin y libros sobire él.

El pedido de la literatura que a Ud. le interese lo puede hacer en las firmas de su pais que tienen relaciones comerciales con V/O "Mezhidunaródnaya Kniga".

Sabemos que você é do. Comitê curtural do PCB, e ago ra está no C.B.D.. Por que vo cếnão assume, como o oscar ? Ele é mais corajoso que você? Cuidado, pois você entrou em nosisa relação. - ..

- Comando de Caça aos Co munistas deseja a você, ati vista da canalha comunista que enxovalha nosso país, um péssimo Natal e que se realize no ano de 1979 nosso con fronto final.

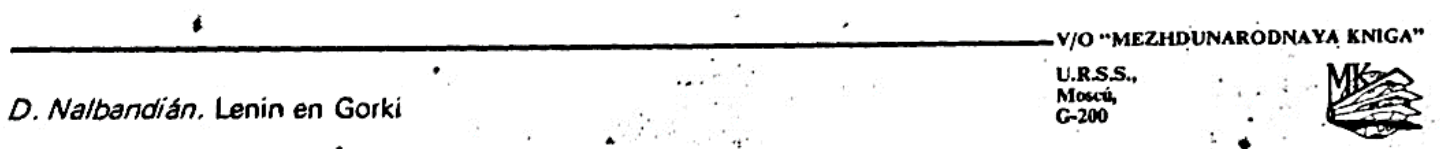

Cartão com ameaça a Dias, assinado pelo Comando de Caça aos Comunistas (1978) 


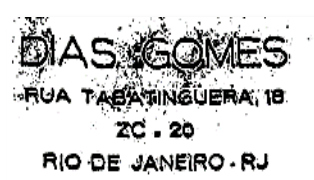

Rio de Janeiro, 21 de agosto de $1: z$ :

IImo. Sr.

José Bonifácio de Oliveira Sobrinho

Perdôe-me isar a "mala direta" para exṕor uma situação que se agrava dia a dia. Primeiramente, vamos aos "considerandos":

1 - Acabo de ser informado de que o último episódio que escrevi para o seriado O, BEM-AMADO (O UASAMENTU DO Ś́LULO) não será gravado por falta de verba.

2 - comunicam-me também que os episódios o ATENTADU PIRUTÁuNICO inspirado no atentado à Tribuna de Imprensa) e SUUUPIRA, AME-A OU DEIXE-A estão definitivamente proibicos pela censimra interna. E que $O$ episódio ZELA DIABO, LANGALEIRU LF. LEUS está sub-júdice, também ameaçado de não ir ao ar. Quanto aos demais episódios, nirnguém sabe se serão ou não liberados.

3 - Além da falta de verba para realizar o episódio u LASAABNTO DO SÉuLL, a Di Ŷreção Geral dos seriados, segundo estou informado, levanta problemas de comportamento de personagens; assusta-se com frases e alusões, mostra temores quanto a isso ou aquilo, levando a indecisão, a insegurança a todo o núcleo e particularmente a mim, que, sinceramente, não sei mais o que pooso ou não posso, o que devo ou não devo escrever.

4 - Esse clina leva cada funcionário da Globo, desde os mais escalonados aos mais mais humildes, a se trabsformar num vensor. Quando passo pelos Porteiros, já temo que un deles me chane de lado e diga: "olhe, vi no VT aquele episódio. Acho que você deve mudar aquela cena, aquilo não pąssa..." por outro lado, ouço explicações delirantes como: "toda semarıa está virıdo un grupo de generais assistir o Vt do BEN-ANADO na sala da Presidência". Ju então: "O Siv avocou a si a censura do BEM-AMALO". Qualquer dia desses vão me dizer que é fo próprio General Figueiredo que cerisucra cada episódio, antes da famosa reunião das nove. Mesmo achando que o brasil é uil paisfonde o Absurco tem carteira de reservista e $\cup P F$, nqão vou a tanto...

Em carta enviada a Boni, em 1981, Dias Gomes reclama da censura interna na Globo 

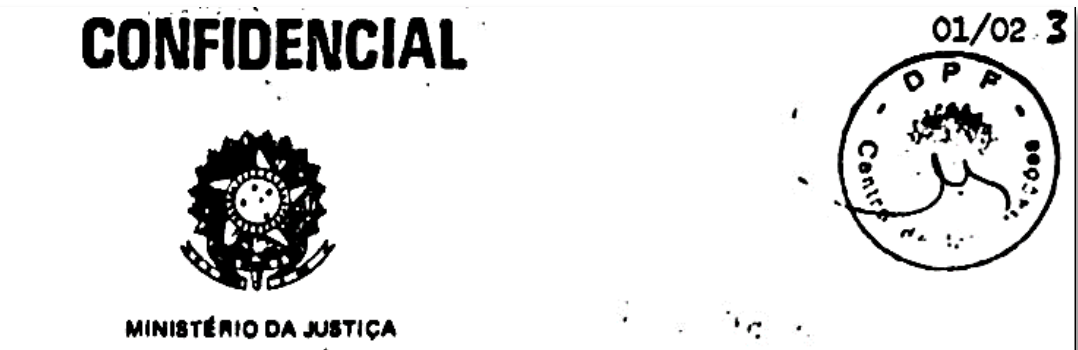
ORPANTAMENTO DE POLICIA FEDERAL

CENTRQ DE INFORMACYOES

INFORME No: $403 / 01 / \mathrm{V} / 85-\mathrm{CI} / \mathrm{DPF}$

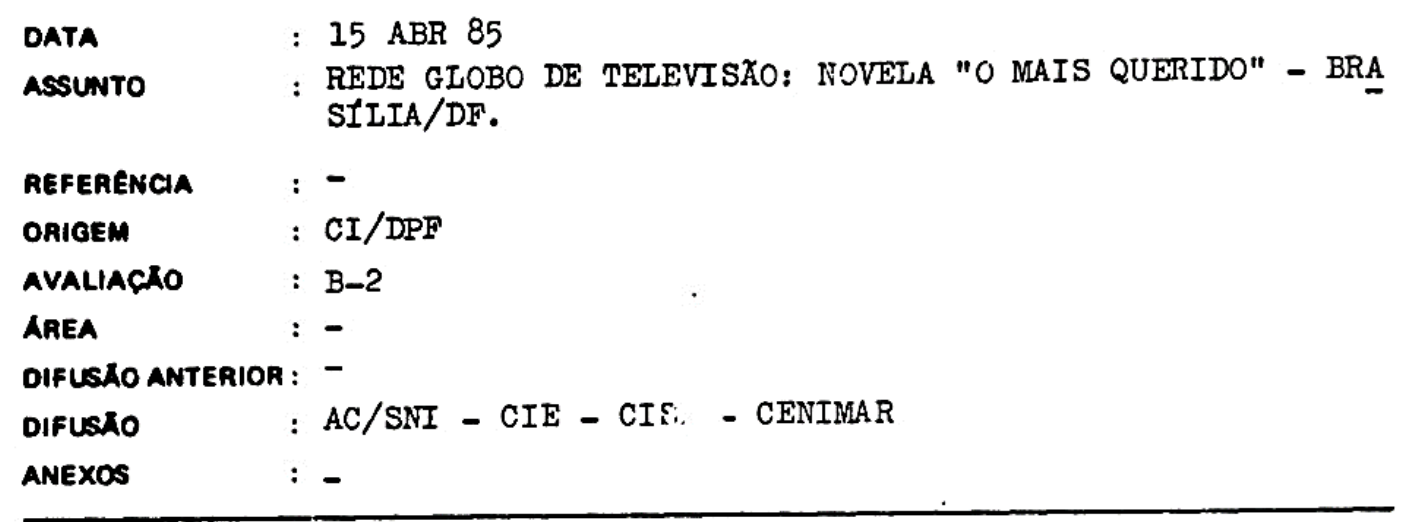

1. Segundo vem sendo divulgado pela Imprensa, a $\underline{R E D E}$ GIOBO DE TELEVISAO tem tido dificuidade para produzir novelas e simila res, devido à exaústão criativa dos escritores e a falta de terno ne cessário para a produção de novo programa, destinado a substituir o que chega ao final.

2. Para suprir esṣa deficiência, a emissora resolveu criar um setor para $\varepsilon$ formação de novos autores.

2.1. Pariindo degsa idéia, inicialmente sugerida por DA NIEI FIIHO, surEiu a CASA DE CRIACAO JANETE CLAIR, hoje já em atividą de e dirigida por DIAS GOMES.

2.2. DIAS GOMES, para exercer sua atividade, conta com a colaboração dos seguintes elementos:

- FEnTtitia GITAP: responsável pela busca e armazenamen to de idéias;

- EUCTIDES MARINHU: responsável pela elaboração de pro jetos e formatos;

- DCC COMPARATO: responsável pelo centro de estudos e treinamento de novos autores; 

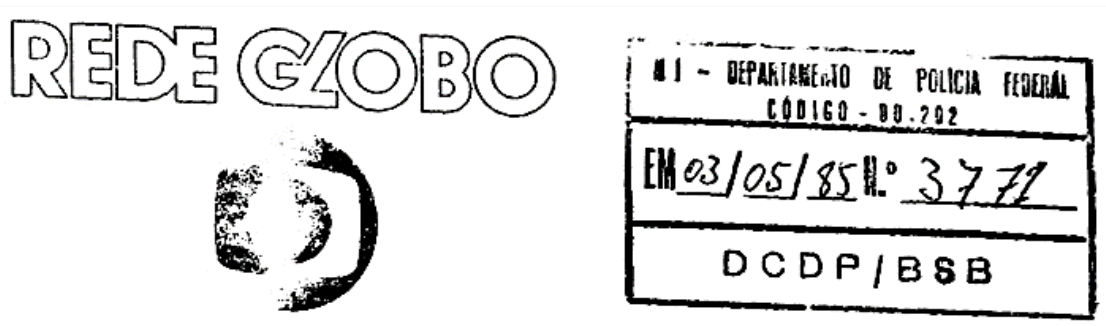

Rio de Janeiro, 30 de abril de 1985.

Ilmo $\mathrm{Sr}$.

Dr. Coriolano de Loyola Cabral Fagundes

DD. Diretor da DCDP/DPF

Brasilia, DF.

Senhor Diretor,

da, da telenovela "Juntando à presente a sinopse, atualizar da, da telenovela "ROQUE SANTEIRO", de autoria do Sr. Dias Gomes, vimos
expor e solicitar o seguinte:

são, após exam Em expediente de 04/07/75, essa Divida novela, comunir a sinopse e os "scripts" dos capítulos 01 a 20 da cita às 20 horas;

b) Entretanto, efetuado o exame dos "Vts" sa Divisão, em expediente de $20 / 08 / 75$, comunicou que havia decidido mudar a classificação inicial, ou seja, que a tele-
novela só poderia ser exibida às 22 horas;

c) Como o dito horário, na ocasião, era ocupado pela telenovela "GABRIELA", grande sucesso de audiência, a TV Globo, recorrendo à Direção dessa Divisão, primeiro e à Direção-Geral do DPF, depois, solicitou que, realizados os cortes julgados necessários, fosse re considerada a decisão, permitindo-se a exibição de "ROQUE SANTEIRO" às 20 horas;

d) Por motivos que, data venia, entendemos ocioso enumerar agora, nem o então liretor dessa Divisão, Dr. Rogério Nunes, nem o Diretor-Ceral do DPF, Cel. Moacyr Coelho, deram acolhida à solicitação. da TV Globo, deixando de levar em consideração que haviam sido fielmente cumpridas todas as exigências e determinações censórias feitas antes, duran te e depois do exame do texto da sinopse e dos capítulos 01 a 20;

e) Amparados na certeza de que não mais subsistem os motivos que deram ensejo àquela decisão censória de 1975, uma vez que o Govermo da Nova República, pela vóz autorizada do Exmo Sr. Minis tro da Justiça, Dr. Fernando Lyra, tornou público que critérios democráticos e atualizados passariam a ser aplicados no exame classificatório dos espetáculos e diversões públicas, solicitamos que V.Sa. se digne mandar pro ceder à revisão de Censura da tèlenovela "ROQUE SANTEIRO", para decidir da possibilidade de a mesma ser liberada para exibição às 20 horas. 
DIVISXO DE CENSURA DE DIVERSOES POBLICAS

OFICIO

N? 795/85-SE/DCDP

Brasilia, 15 de maio de 1985.

\section{Senhor Diretor:}

Comunicamos a V.Sa. que a sinopse da teleno vela intitulada "ROQUE SANTEIRO" de autoria de Dias Gomes, foi 1iberada para o horärio de 20:00 horas condicionada ao exame de videofita.

Pedimos especial atenção da Emissora para as abordagens de adultério, prostituição, insasisfação sexual, 1ivre relação amorosa e religião, principalmente mensagens favoráveis ao movimento dissidente da Igreja Católica, que deverão receber tra tamento adequado ao horário e veículo.

Lembramos que sempre que a obra sofra alteraçōes, faz-se necessāri a remessa dos adendos a este Orgão.

Atenciosamente,

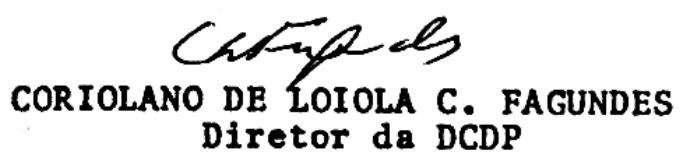

Ilmo. Senhor

DANIEL FILHO

DD. Diretor Geral da Central Globo de Produçäo

Rede Globo de Televisão

RIO DE JANEIRO - RJ

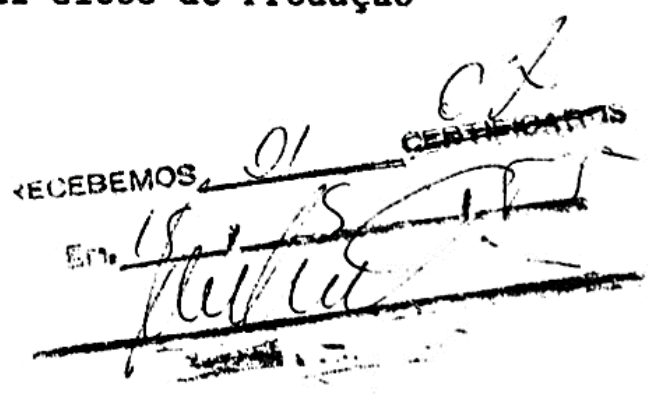

Diretor da Censura libera 'Roque', mas com ressalvas a questões morais e políticas 


\section{DIVISÃO DE CENSURA DE DIVERSOES POBLICAS}

OFICIO

$\mathrm{N}^{\circ} 1.293 / 85-\mathrm{SE} / \mathrm{DCDP}$

Brasilia, 18 de julho de 1985 .

\section{Senhor Assessor:}

Na oportunidade, dirigimo-nos a V.Sa, para so licitar esclarecimentos mais detalhados sobre a telenovela "ROQUE SANTEIRO", no que tange às situaçōes ligadas ao personagem "João Li geiro", caracterizado na sinopse como vaqueiro destemido.

At enciosamente,

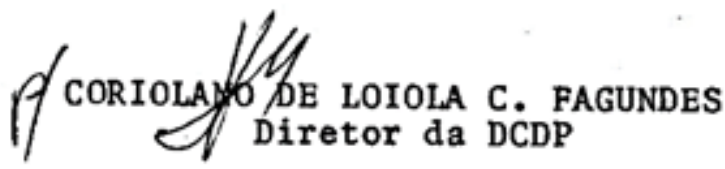

Ilmo. Sr.

DUARTE F. FRANCO

Assessor da CGP

Rede Globo de Televisão

RIO DE JANEIRO - RJ

Verdadeira preocupação da Censura não sai do armário: personagem seria gay? 


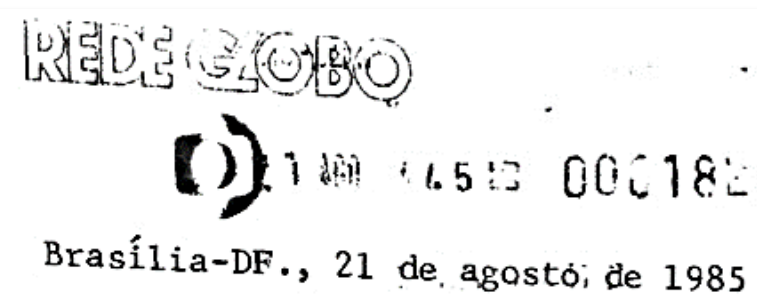

Ilmo. Sr。

Dr. Coriolano de Loyola Cabral Fagundes

DD. Diretor da DCDP/DPF

Brasilia-DF

Senhor Diretor:

Vimos como disposto na legislação pertinente em vigor, solicitar que V.Sa., se digne mandar proceder a revisão' de Censura do capítulo 53 da telenovela "Roque Santeiro", de autoria do $\mathrm{Sr}$. Dias Gomes, para decidir da possibilidade de cancelamen to do corte assinalado à página 17 do respectivo "script", tendo em conta as seguintes ponderações:

a) A aplicação do sợo antiofídico em Salú docorre de um acidente, ou seja, de um equívoco do enfermeiro, e não de uma tentativa de assassinato, como se vê claramente na cena cortada.

b) Salú não morrera, como mostram os capítulos seguintes.

Grato pela boa atenção de V.Sa., aproveita-' mos o ensejo para reiterar nossos protestos de alta estima e consi deração.

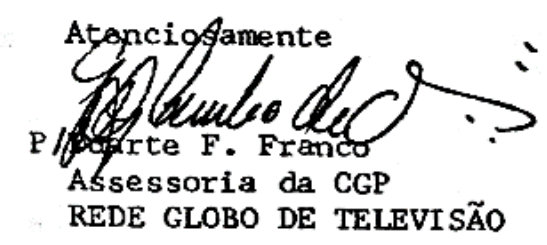

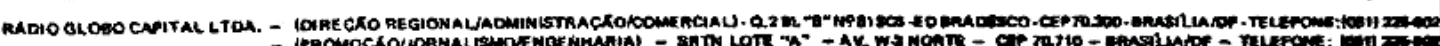


ROQUE SANTEIRO

CAP $; 97$

ia me fazer sofrer tudo que eu $j a ́$

sofri

de novo : ?

MARCDIINA

Se rocê soiresse tanto como diz, não ia.

marcar casamento escondido!

MALTA

Isso é outro assunto, outras conveniências...

Não tom nada a ver com seguro, nem com Margari-

da, Nem com a senhora!

MARCELINA Isso é que eu não sei :

Malta joga tudo.

MALTA:

Pois muito que bem, minha sogra. A senhora não

vai mesmo acreditar em mim, não é ? Então vai

Iá e conta tudo pra Tânia.... Desgraça com a feli-

cidade da menina de uma vez a Me denuncia pra

polfcia, faz o que a senhora quiser : Eu prefi-

ro me explicar no banco dos réus, a aguentar es-

sa tortura :

Marcelina se assusta.

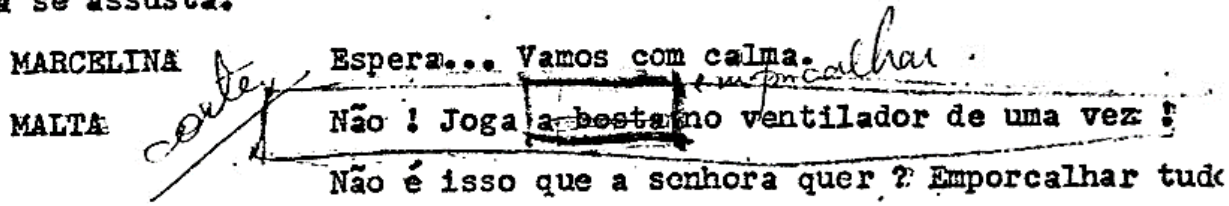

MARCSIINA Eu não quero emporcalhar nada.

MALTA:

quer enporcalhar sim. E se a senhora näo faz, el

faço...

Dirige-se parai a porta.

MAITA

Vou chamar ranta aqui, a senhora emporcalha o

futuro dela de ume vez por todas:

MARCBIINA Não! Bspera! !'

Malta pára. Volta-se para elab Marcelina entrega os pontos.

MAREELINA - Bu não posso fazer isso com ela... Afinal... Ñ̃o

tenho nenhura prova.

Malta dá o golpe final.

MALTS

Pois se não tem prova, se não pede fazer... en-

tão fecha esse esgoto que é a sua boca pra sem.

Censores vetam o termo 'bosta'; no mesmo capítulo, liberam 'cocozinho'e explicam a diferença: cocozinho 'foi dito de forma menos incisiva e desprovida de agressividade' 


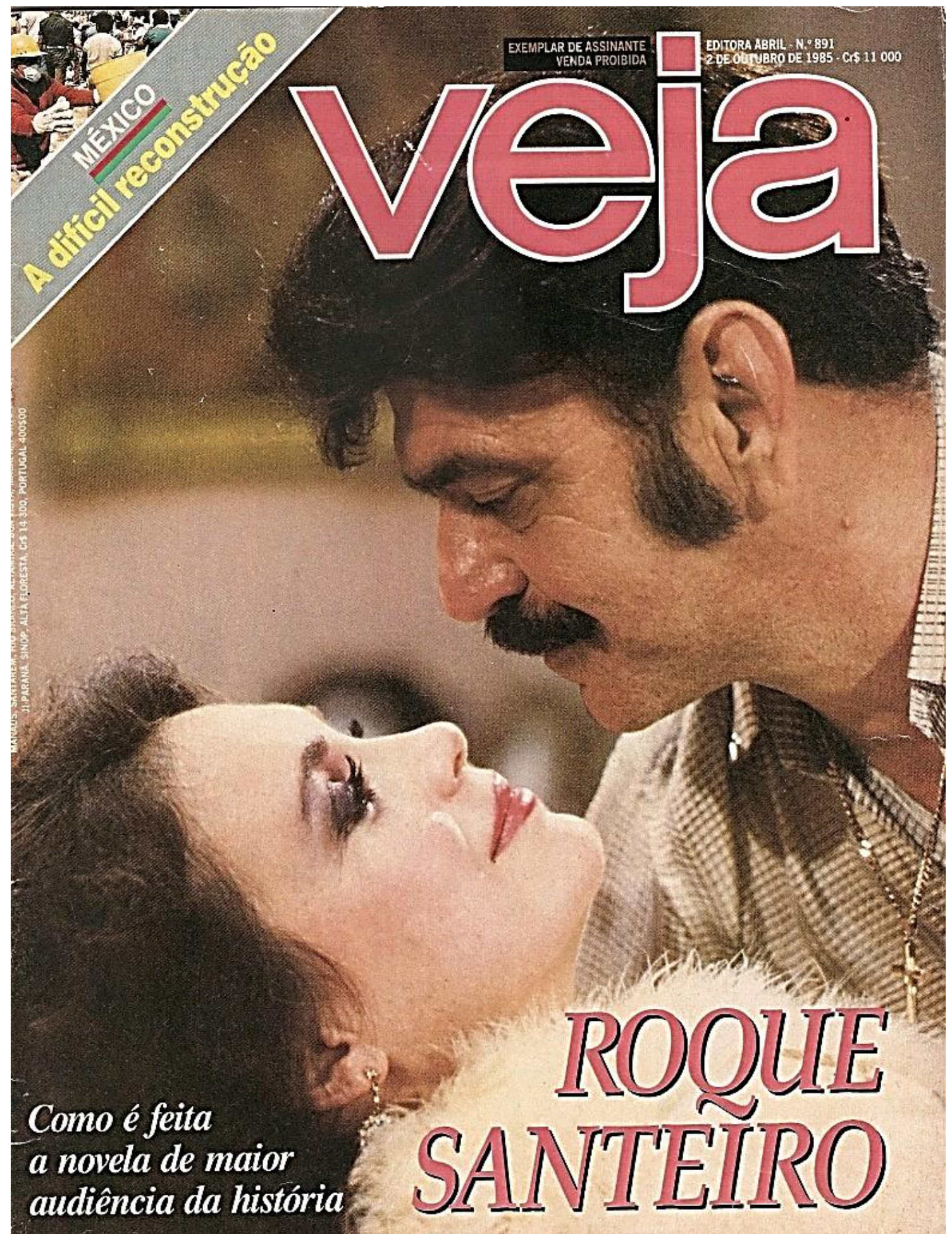

Capa da 'Veja'; euforia com o Ibope e com o fim da ditadura ofuscam a censura sofrida pela novela da Nova República, pouco noticiada: é preciso manter o mito 


\title{
7. REFERÊNCIAS BIBLIOGRÁFICAS
}

\author{
LIVROS, ARTIGOS E TESES
}

BAFFA, Ayrton. Nos porões do SNI - O retrato do monstro de cabeça oca. Rio de Janeiro: Objetiva, 1989

BASBAUM. Hersch W. Lauro César Muniz solta o verbo. São Paulo: Imprensa Oficial, 2010

BUCCI, Eugênio. Brasil em tempo de TV. São Paulo: Boitempo Editorial, 1997 . Antropofagia patriarcal. In: BUCCI, Eugênio (org.). A TV aos 50.

São Paulo: Editora Fundação Perseu Abramo, 2000

. Censura, marcos regulatórios e tecnologia. In: COSTA, Maria Cristina

Castilho (Org.). A censura em debate. São Paulo: ECA/USP, 2014

. Ubiquidade e instantaneidade no telespaço público: algum pensamento sobre televisão. Revista Caligrama. Revista de Estudos e Pesquisa em Linguagem e Mídia, vol. 2, número 3-setembro a dezembro de 2006

CALABRE, Lia. A participação do rádio no cotidiano da sociedade brasileira (1923-1960). Rio de Janeiro: Fundação Casa de Rui Barbosa, sd.

CARDENUTO, Reinaldo. A sobrevida da dramaturgia comunista na televisão dos anos 1970 - o percurso de um realismo crítico em negociação. In: NAPOLITANO, Marcos;

CZAJKA, Rodrigo; MOTTA, Rodrigo Patto Sá. Comunistas Brasileiros - Cultura política e produção cultural. Belo Horizonte: Editora UFMG, 2013

CELLARD, André. A análise documental. In: A pesquisa qualitativa. Enfoques epistemológicos e metodológicos. Petrópolis: Vozes, 2008

CLARK, Walter, com PRIOLLI, Gabriel. O campeão de audiência - uma autobiografia. São Paulo: Editora Best Seller, 1991

COSTA, Maria Cristina Castilho. Opinião pública, comunicação, liberdade de expressão e censura. In: Idem (Org.). A censura em debate. São Paulo: ECA/USP, 2014

CUNHA, Euclides (1902). Os Sertões. São Paulo: Saraiva; edição de 2011 Dicionário da TV Globo - vol. 1: Programas de Dramaturgia \& Entretenimento. Rio de Janeiro: Jorge Zahar Editor, 2003 
ELIAS, Norbert \& Scotson. John L. Os estabelecidos e os outsiders. Rio de Janeiro: Jorge Zahar, 2000

FAGUNDES, Coriolano de Loyola Cabral. Censura \& liberdade de expressão. São Paulo: Editora Taika, 1974

FALCÃO, Armando. Tudo a declarar. São Paulo: Nova Fronteira, 1989

FERNANDES, Ismael. Telenovela brasileira. Memória. São Paulo: Brasiliense, $3^{\text {a }}$ edição, 1994

FILHO, Daniel. Antes que me esqueçam. Rio de Janeiro: Editora Guanabara, $3^{\text {a }}$ edição, 1988

FRANCIS, Paulo. Prefácio de 1964. In: GOMES, Dias. O Berço do Herói. 4 a edição. Rio de Janeiro: Bertrand Brasil, 2005

GASPARI, Elio. A ditadura envergonhada. São Paulo: Companhia das Letras, 2002

A ditadura escancarada. São Paulo: Companhia das Letras, 2002

A ditadura derrotada. São Paulo: Companhia das Letras, 2003

A ditadura encurralada. São Paulo: Companhia das Letras, 2004

A ditadura acabada. Rio de Janeiro: Intrínseca, 2016

GOFFMAN, E. Estigma. 2a ed. Rio de Janeiro: Jorge Zahar, 1978

GOMES, Dias. A Revolução dos Beatos. In: Idem. A Invasão e A Revolução dos

Beatos. Coleção Vera Cruz, vol. 40. Rio de Janeiro: Civilização Brasileira, 1962

Peças da Juventude. Rio de Janeiro: Bertrand Brasil, 1994

O Berço do Herói, 4a ed. Rio de Janeiro: Bertrand Brasil, 1997

Apenas um subversivo. Rio de Janeiro: Bertrand Brasil, 1998

GOMES, Mayra Rodrigues. In: COSTA, Maria Cristina Castilho (Org.). A censura em debate. São Paulo: ECA/USP, 2014

HALL, Stuart. A identidade cultural na pós-modernidade. Rio de Janeiro: DP\&A, 1999

KUSHNIR, Beatriz. Cães de Guarda - Jornalistas e censores do AI-5 à Constituição de 1988. São Paulo: Boitempo, 2004

JÚNIOR, Gonçalo. Pais da TV. São Paulo: Conrad, 2001 
LAURENZA, Ana Maria de Abreu. Lacerda X Wainer - O Corvo e o Bessarabiano. São Paulo: Senac, 1998

LOPES, Maria Immacolata Vassallo. Telenovela brasileira: uma narrativa sobre a nação. São Paulo: Comunicação \& Educação, volume 1, número 26, 2003

Loyola, 2005

Pesquisa em Comunicação. São Paulo: Edições

MARTÍN-BARBERO, Jesús. Viagens da telenovela: dos muitos modos de viajar em, por desde e com a telenovela. In: LOPES, Maria Immacolata Vassallo (org.). Telenovela - Internacionalização e Interculturalidade. São Paulo: Edições Loyola, 2004

MATTELART, Armand e MATTELART, Michèle. História das teorias da Comunicação. São Paulo: Loyola, 1998

MATTOS, David José Lessa (org.). Pioneiros do rádio e da TV no Brasil. São Paulo: Códex, 2004

MELlO, Zuza Homem de. A Era dos Festivais - Uma Parábola. São Paulo: Editora 34,2003

MERCADO, Antonio. Prefácio. In: GOMES, Dias. Peças da Juventude. Rio de Janeiro: Bertrand Brasil, 1994

MICELI, Sergio. A noite da madrinha. São Paulo: Companhia das Letras, 2005

MORAES, Dênis de. Vianinha: o cúmplice da paixão. Rio de Janeiro: Nórdica, 1991

O imaginário vigiado - a imprensa comunista e o realis mo

socialista no Brasil. Rio de Janeiro: José Olympio Editora, 1994

MORAIS, Fernando. Chatô: o rei do Brasil. São Paulo: Companhia das Letras, 1994

MOTTER, Maria Lourdes. Mecanismos de renovação do gênero da telenovela empréstimos e doações. In: LOPES, Maria Immacolata Vassallo (org.). Telenovela Internacionalização e Interculturalidade. São Paulo: Edições Loyola, 2004

MOYA, Álvaro de. Glória in Excelsior - Ascensão, apogeu e queda do maior sucesso da televisão brasileira. São Paulo: Imprensa Oficial, 2004

NAPOLITANO, Marcos. 1964 - História do regime militar brasileiro. São Paulo: Contexto, 2014

A "estranha derrota" - Os comunistas e a resistência cultural ao regime militar (1964-1968). In: NAPOLITANO, Marcos; CZAJKA, Rodrigo; MOTTA, Rodrigo Patto Sá. Comunistas Brasileiros - Cultura política e produção cultural. Belo Horizonte: Editora UFMG, 2013 
NEGRÃO, Walter. O processo de criação da telenovela. In: LOPES, Maria Immacolata Vassallo (org.). Telenovela - Internacionalização e Interculturalida de. São Paulo: Edições Loyola, 2004

OLIVEIRA, Lúcia Maciel Barbosa de. "Noss os comerciais, por favor!": a televisão brasileira e a Escola Superior de Guerra: o caso Flávio Cavalcanti. São Paulo: Beca Produções Culturais, 2001

OLIVEIRA SOBRINHO, José Bonifácio de. O livro do Boni. Rio de Janeiro: Casa da Palavra, 2011

ORTIZ, Renato. Cultura brasileira e identidade nacional. São Paulo: Brasiliense, 1985

PERALVA, Osvaldo. O retrato. São Paulo: Três Estrela, 2015

PIRES, Álvaro P. Amostragem e pesquisa qualitativa: ensaio teórico e metodológico. In: POUPART, Jean et al. A pesquisa qualitativa - Enfoques epistemológicos e metodológicos. Petrópolis: Vozes, 2008

RAMOS, José Mário Ortiz. Cinema, Estado e lutas culturais. Rio de Janeiro: Paz e Terra, 1983

RAMOS, José Mário Ortiz; BORELLI, Silvia H. Simões. A telenovela diária. In: ORTIZ. Renato; BORELLI, Silvia Helena Simões; RA MOS, José Mário Ortiz. Telenovela - história e produção, $2^{\text {a }}$ edição. São Paulo: Editora Brasiliense, 1991

REIMÃO, Sandra. Censura a livros no Brasil - breve panorama histórico. In: COSTA, Maria Cristina Castilho (Org.). A censura em debate. São Paulo: ECA/USP, 2014

RIBKE, Nahuel. Telenovela writers under the military regime in Brazil: Beyond the cooption and resistance dichotomy. Media, Culture \& Society, 2011

Decoding television censorship during the last brazilian military regime - The censor as negotiator and censorship as a semi-open interpretative process, Media History, vol 17, n. 1, 2011

The genre of live studio audience programmes in a political contexto: The Flavio Cavalcanti Show and de brazilian military regime. Screen, vol. 54, ed. 3, 2013

The brazilian military regime and television censorship: between the internal logics of production and the political context. Revista de História, n. 169, 2013

RIDENTI, Marcelo. Em bus ca do povo brasileiro - artistas da revolução, do CPC à era da TV. Rio de Janeiro: Record, 2000 
ROLEMBERG, Denise. O Bem-Amado e a censura - uma relação rigorosa ou flexível? In: NAPOLITANO, Marcos; CZAJKA, Rodrigo; MOTTA, Rodrigo Patto Sá.

Comunistas Brasileiros - Cultura política e produção cultural. Belo Horizonte: Editora UFMG, 2013

SAID, Edward. Orientalismo. São Paulo: Companhia das Letras, 1990

SACRAMENTO, Igor Pinto. Nos tempos de Dias Gomes - A Trajetória de um intelectual comunista nas tramas comunicacionais, doutorado na UFRJ, 2012

Por uma teledramaturgia engajada - a experiência de dramaturgos comunistas com a televisão dos anos de 1970. In: NAPOLITANO, Marcos; CZAJKA, Rodrigo; MOTTA, Rodrigo Patto Sá. Comunistas Brasileiros - Cultura política e produção cultural. Belo Horizonte: Editora UFMG, 2013

SCHWARCZ, Lilia M. e STARLING, Heloisa M. Brasil: uma biografia. São Paulo: Companhia das Letras, 2015

SILVEIRA, Ênio. Orelha escrita em 1965. In: GOMES, Dias. O Berço do Herói. $4^{\text {a }}$ edição. Rio de Janeiro: Bertrand Brasil, 2005

SIMÕES, Inimá. Nunca fui santa (episódios de cens ura e autocens ura). In: BUCCI, Eugênio (org.). A TV aos 50. São Paulo: Editora Fundação Perseu Abramo, 2000

SODRÉ, Muniz. Sobre a episteme comunicacional. MATRIZes, 1, Ano 1, 2007

SOUZA, Miliandre Garcia de. Do Arena ao CPC: o debate em torno da arte engajada no Brasil (1959-1964), mestrado da Universidade Federal do Paraná, 2002

ditadura militar (1964-1985), Rio de Janeiro: UFRJ, 2008

STEPHANOU, Alexandre. Censura no regime militar e militarização das artes. Porto Alegre: Edipucrs, 2001

WALLACH, Joe. Meu capítulo na TV Globo. Rio de Janeiro: Top Books, 2011

VELTMAN, Henrique. Do Beco da Mãe a Santa Teresa. São Paulo: H. Veltman, 2010

XEXÉO, Artur. Janete Clair: a usineira de sonhos. Rio de Janeiro: Relume, 2005

\section{IMPRENSA}

(veículos em ordem alfabética e reportagens em ordem cronológica)

Folha de S.Paulo

KHAN, Ali. O Cabresto. Folha de S.Paulo, 3/7/1965, p. 9 
Política na opinião alheia. Folha de S.Paulo, 3/7/1965, p. 4 [matéria não assinada]

Globo decide não exibir "Roque Santeiro". Folha de S.Paulo, 28/8/1975, p. 48 [matéria não assinada]

O "Santeiro" leva artistas ao presidente. Folha de S.Paulo, 29/8/1975, p. 1 [chamada não assinada]

Protestos de artistas contra a proibição. Folha de S.Paulo, 29/8/1975, p. 40 [matéria não assinada]

DINES, Alberto. Ascenção e milagres de "Roque Santeiro" - "O Jornal dos Jornais". Folha de S.Paulo, 31/8/1975, p. 6

LAGO, Graça. As razões de "Roque Santeiro" por Dias Gomes. Folha de S.Paulo, São Paulo, 5/9/1975, p. 40

DINES, Alberto. A Reunião dos Escoteiros - "O Jornal dos Jornais". Folha de S.Paulo, São Paulo, 19/10/1975, p. 6

Dias Gomes e o absurdo da realidade. Folha de S.Paulo, 31/7/1976, p. 27 [matéria não assinada]

Censura - Também é proibida a "Despedida de Casado". Folha de S.Paulo, 24/12/1976, p. 21 [matéria não assinada]

CASTRO, Tarso de. Despedida de conquistado. Folha de S.Paulo, 25/12/1976, p. 20

Censura - O diretor diz como salva a nossa moral. Folha de S.Paulo, 30/12/1976, p. 36 [matéria não assinada]

DINES, Alberto. Balanço e sacolejo - "O Jornal dos Jornais". Folha de S.Paulo, 2/1/1977, p. 6

SOARES, Dirceu. Televisão. E essa novela vai passar? Folha de S.Paulo, 4/1/1977, p. 29

A classe média vista no espelho favorito. Folha de S.Paulo, 4/7/1977, p. 23 [matéria não assinada]

Cinco mil disputam 58 vagas de censores. Folha de S.Paulo, 2/8/1977 [matéria não assinada]

DIAFÉRIA, Lourenço. Herói. Morto. Nós. Folha de S.Paulo, 1/9/1977, p. 44

“Estado de Sítio" liberado com cortes. Folha de S.Paulo, 16/1/1981, p. 33 [matéria não assinada] 
ALMEIDA, Miguel de. Uma piada transforma da em seriado de sucesso. Folha de S.Paulo, 27/6/1981

Emergência de novo em Brasília; Blecaute total atinge quatro Estados. Folha de S.Paulo, 19/4/1984, p. 1 [chamada não assinada]

No Rio, Tancredo ouve artistas e intelectuais. Folha de S.Paulo, 7/11/1984, p. 44 [matéria não assinada]

PRIOLLI, Gabriel. A emergência e a censura na televisão. Folha de S.Paulo, 27/4/1984, p. 44

ÁlVARO, Marcia e GALVEZ, Virgínia. SNI controla Censura, diz Coriolano. Folha de S.Paulo, 11/2/1985, p. 23

COURI, Norma. Muda o governo, chega a nova censura. Folha de S.Paulo, $15 / 2 / 1985$, p. 31

Cens ura prévia à TV divide população. Folha de S.Paulo, 24/2/1985, p. 49 [matéria não assinada]

Cens ura política acaba amanhã, declara Lyra. Folha de S.Paulo, 14/3/1985, p. 6 [matéria não assinada]

Cens urados debaterão os rumos da censura. Folha de S.Paulo, 22/3/1985, p. 50 [matéria não assinada]

Cens ura pendura tesoura e será só classificatória. Folha de S.Paulo, 26/3/1985, p. 36 [matéria não assinada]

SUZUKI JR., Matinas. De cens urado a censor. Folha de S.Paulo, 11/4/1985, p. 2

“Roque Santeiro", dez anos depois. Folha de S.Paulo, 29/4/1985, p. 23 [matéria não assinada]

Regina Duarte volta hoje à Globo. Folha de S.Paulo, 28/5/1985, p. 27 [matéria não assinada]

BARROS, Ambar de. "Roque Santeiro", um história de falsos milagres. Folha de S.Paulo, 24/6/1985, p. 24

Pimenta diz temer censura centralizada. Folha de S.Paulo, 30/7/1985, p. 29 [matéria não assinada]

FILHO GONÇALVEZ, Antonio. "Roque Santeiro": A novela conquista o País. Folha de S.Paulo, 31/07/1985, p. 40

CASTRO, Ruy. Liberdade para Dias Gomes. Folha de S.Paulo, 6/8/1985, p. 30 
CEZIMBARA, Marcia. No fim, Roque mata navalhada. Folha de S.Paulo, 26/10/1985, p. 47

As muitas vidas de "Roque Santeiro". Folha de S.Paulo, 9/11/1985, p. 60 [matéria não assinada]

Beijo, o limite da censura na novela. Folha de S.Paulo, 25/10/1985, p. 54 [matéria não assinada]

GONÇALVES, Marcos Augusto. O poder de vetar do Juizado de Menores. Folha de S.Paulo, 14/12/1985, p. 49

Triste país. Folha de S.Paulo, 5/2/1986, p. 2 [editorial não assinado]

FRANCIS, Paulo. Ave Sarney. Folha de S.Paulo, 8/2/1986, p. 39

Final de "Roque Santeiro" decepcionou. Folha de S.Paulo, 24/2/1986, p. 21 [matéria não assinada]

Programa dos que não quiseram saber da telinha. Folha de S.Paulo, 23/2/1986, p. 81 [matéria não assinada]

SERVA, Leão. Baixou o Austral. Folha de S.Paulo, 1/3/1986, p. 41

MATTOS, Laura. Disputa ameaça publicação de diário de Dias Gomes. Folha de S.Paulo, 6/6/2001, p. E4

Governo decide subir classificação de "Duas Caras" para 14 anos. Folha de S.Paulo, 20/12/2007, p. A13

VALENTE, Rubens. Governo espionou críticos mesmo após fim da ditadura. Folha de S.Paulo, 31/5/2010, p. A4

BALTHAZAR, Ricardo et al. Tudo sobre a ditadura militar. Folha de S.Paulo, 23/3/2014; disponível em arte.folha.uol.com.br/especiais/2014/03/23/o-golpe-e-aditadura-militar

\section{$\underline{\text { Jornal da Tarde }}$}

Um herói impróprio para as 20h. Jornal da Tarde, 27/8/1975, p. 19 [matéria não assinada]

“Roque Santeiro", capítulo II. Jornal da Tarde, 28/8/1975 [matéria não assinada]

A tevê encena um grande sucess o: a censura. Jornal da Tarde, 29/8/1975 [matéria não assinada] 
O Substituto de "Roque Santeiro". Jornal da Tarde, São Paulo, 5/9/1975 [matéria não assinada]

PESSOA, Lenildo Pacheco. Uma questão de horário - I e Uma questão de horário II. Jornal da Tarde, São Paulo, 23 e 24/9/1975

Dias Gomes, lutando contra a censura. Com bom humor. Jornal da Tarde, 22/6/1981, p. 23 [matéria não assinada]

RICCA, Regina. A recriação de "Roque Santeiro". E o sucesso, dez anos depois. Jornal da Tarde, 8/8/1985

\section{Jornal do Brasil}

Dias Gomes grava seu depoimento. Jornal do Brasil, 10/2/1977 [matéria não assinada]

Dias Gomes - "Somos uma geração de quixotes". Jornal do Brasil, 4/5/1977 [matéria não assinada]

ARAGÃO, Diana. Sinal de Alerta, de Dias Gomes - Uma novela sobre o direito de viver. Jornal do Brasil, 31/7/1978

Teatrólogo anseia por abertura. Jornal do Brasil, 29/1/1979 [matéria não assinada]

Dias Gomes lança amanhã o livro “O Rei de Ramos”. Jornal do Brasil, 31/5/1979 [matéria não assinada]

Dias Gomes / Perfil sem piedade de certa esquerda. Jornal do Brasil, 14/5/1984 [matéria não assinada]

Dias retoma "Roque". Jornal do Brasil, 19/11/1985 [matéria não assinada]

Dias Gomes acusa Aguinaldo Silva de megalomania aguda e receita internação. Jornal do Brasil, 23/01/1992, p. 1 [matéria não assinada]

\section{$\underline{\text { O Estado de S. Paulo }}$}

Suspensa exibição de novela. O Estado de S. Paulo, 27/8/1975 [matéria não assinada]

Novela é liberada mas TV a cancela. O Estado de S. Paulo, 28/8/1975 [matéria não assinada]

MAIA, Paulo. "Roque Santeiro", um episódio que deixa margem a dúvidas. O Estado de S.Paulo, 9/9/1975

Folclore, a saída para Dias Gomes. O Estado de S. Paulo, 30/7/1976 [matéria não assinada] 
E volta o autor da novela "Roque Santeiro". O Estado de S. Paulo, 20/11/1985 [matéria não assinada]

MAYRINK, José Maria. Acervo mostra as marcas da censura. O Estado de S. Paulo, http://topicos. estadao.com.br/acervo-estadao, 23/5/2012

\section{Veja}

O autor e o meio. Veja, 29/7/1970, p. 73 [matéria não assinada]

Novela a dois. Veja, 10/2/1971, p. 58 [matéria não assinada]

A arte popular das novelas. Veja, São Paulo, 24/1/1972, p. 3-5 [matéria não assinada]

A novela quase na maioridade. Veja, 12/7/1972, p. 80 [matéria não assinada]

O fim de "Roque". Veja, ed. 365, 3/09/1975, p. 17 [matéria não assinada]

Livre. Veja, 29/6/1977 [matéria não assinada]

MACIEL, Luís Carlos. Guerra de majestades. Veja, ed. 550, 21/3/1979

Troca de autores. Veja, ed. 826, 4/7/1984, p. 74 [matéria não assinada]

O retorno do mito, Veja, ed. 880, 17/7/1985, p. 108-109 [matéria não assinada]

Um dia em Asa Branca. Veja, ed. 891, 2/10/1985, p. 132-140 [matéria não assinada]

DIAS, Etevaldo e TEIXEIRA, Hélio. Censura mutila "Roque Santeiro" - coluna Radar. Veja, ed. 894, 23/10/1985, p. 47

Troca de mãos. Veja, ed. 899, 27/11/1985, p. 32 [matéria não assinada]

O milagre de "Roque". Veja, ed. 912, 26/2/1986, p. 96-98 [matéria não assinada]

A esquerda da Censura. Veja, ed. 939, 3/9/1986 [matéria não assinada]

Para a maioria, Figueiredo é desconhecido. Veja, 11/1/1978, ed. 488, p. 58 [matéria não assinada]

XEXÉO, Artur. O front global. Veja, ed. 673, 13/8/1989, p. 111

\section{$\underline{\text { Outros }}$}

SILVA. Abel. Do Pagador de Promessas ao Bem-Amado. Opinião, 4/3/1973, p. 19 Apertos levaram Dias Gomes à TV. E ele gostou. Tribuna da Bahia, 29/1/1975 
Dias Gomes: Escrever para a televisão é viver entre a sanidade e a loucura. Correio do Povo, 14/9/1977 [matéria não assinada]

MARINHO, Flavio. A volta de Dias Gomes ao teatro - Uma comédia musical, ' $O$ Rei de Ramos'. Parceiro: Chico Buarque. O Globo, 11/03/1979

Entrevista - Dias Gomes. Ele Ela, 9/1979 [matéria não assinada]

Novela de D. Gomes pode ser liberada pela censura. Tribuna da Imprensa, 14/9/1979 [matéria não assinada]

Por uma fresta, Dias Gomes espia a liberdade e o mundo lá fora. Tribuna da Imprensa, 26/6/1980 [matéria não assinada]

Corte em peça leva Dias Gomes à Censura. O Globo, 19/3/1981, p. 12 [matéria não assinada]

FALCONE, Maria Carolina. Dias Gomes: Não haverá censura política com o presidente Tancredo Neves. Tribuna da Imprensa, 8/11/1984, p. 12

d'ALMEIDA, Regina. Dias Gomes - Um novo tempo com "Roque Santeiro". Última Hora, 14/5/1985

BRANDÃO, Hermínia. "Roque Santeiro", a fórmula que tinha tudo para dar certo. Folha da Tarde, 8/8/1985

Dias Gomes. Diário Popular, 11/8/1985 [matéria não assinada]

Mania nacional, Isto É, 14/8/1985, p. 32-35 [matéria não assinada]

COURI, Norma. Playboy entrevista Dias Gomes, Playboy, ed. 125, 12/1985, p. 49

CASTRO, Ruy. Playboy entrevista Aguinaldo Silva. Playboy, ed. 204, 7/1992, p. 31

MAGALHÃES, Simone. "Esta peça é maldita”. O Dia, Caderno O Dia D, 24/10/1996, p. 3

GOMBATA, Marília. Dom Eugênio, agente duplo. Carta Capital, 18/10/2013, disponível em http:/www.cartacapital.com.br/revista/770/dom-eugenio-agente-duplo$\underline{6767 . h t m l}$

FRIAS FILHOS, Otavio. O tribuno da imprensa. Revista Piauí, n. 91, 4/2014

GASPARI, Elio. Uma bomba na noite. O Globo, 29/7/2015, disponível em http://oglobo.globo.com/sociedade/uma-bomba-na-noite-16986664 


\section{SITES}

Câmara dos Deputados (camara.leg.br)

Centro de Pesquisa e Documentação de História Contemporânea do Brasil, da Fundação Getúlio Vargas (cpdoc.fgv.br)

Centro Nacional de Folclore e Cultura Popular (cnfcp.gov.br)

Fundação Roberto Marinho (robertomarinho.com.br)

Itaú Cultural (enciclopedia.itaucultural.org.br)

Memória Globo (memoriaglobo.globo.com)

Palácio do Planalto (planalto.gov.br)

Presidência da República (biblioteca.presidencia.gov.br)

Polícia Civil do Rio de Janeiro (policiacivil.rj.gov.br)

Pró TV / Museu da TV (museudatv.com.br)

Teledramaturgia (teledramaturgia.com.br)

\section{VÍDEOS}

Entrevista de Dias Gomes ao "Roda Viva", 12/6/1995, em

http://www.rodaviva. fapesp.br/materia/405/entrevistados/dias_gomes_1995.htm

Documentário "Sobral Pinto - O Homem que não Tinha Preço", 2013; direção Paula Fiúza 